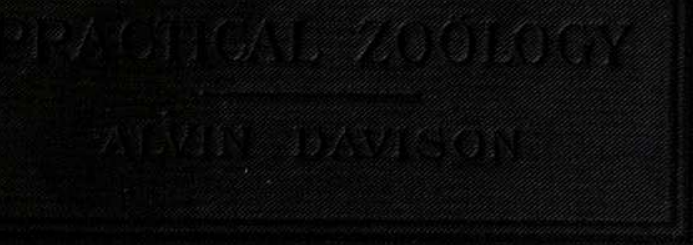

\%

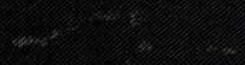




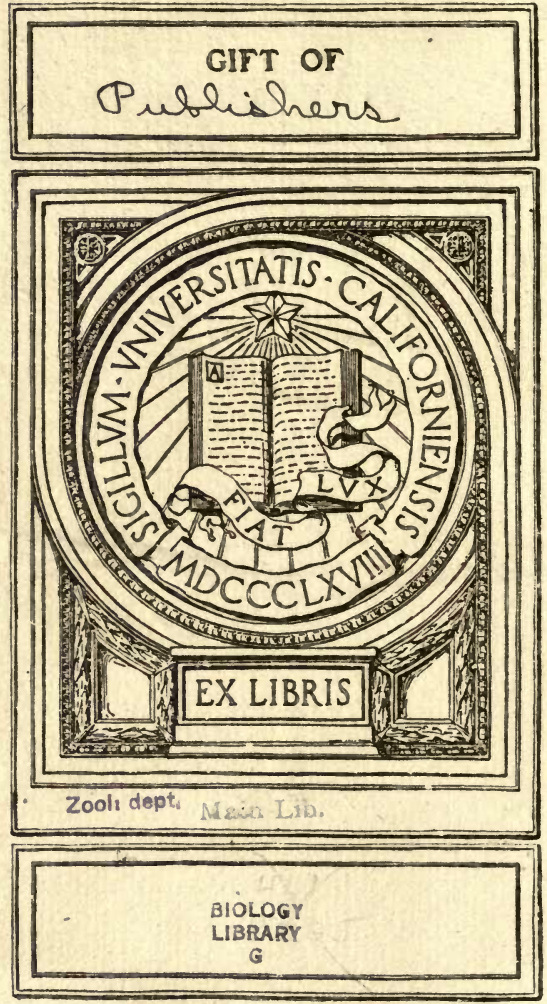




40 


$\because \because \because \quad \vdots \because \vdots \vdots \because \vdots \vdots \vdots$

$\therefore \quad \vdots \because \because \because \because \vdots \vdots \vdots \therefore \circ \cdots$

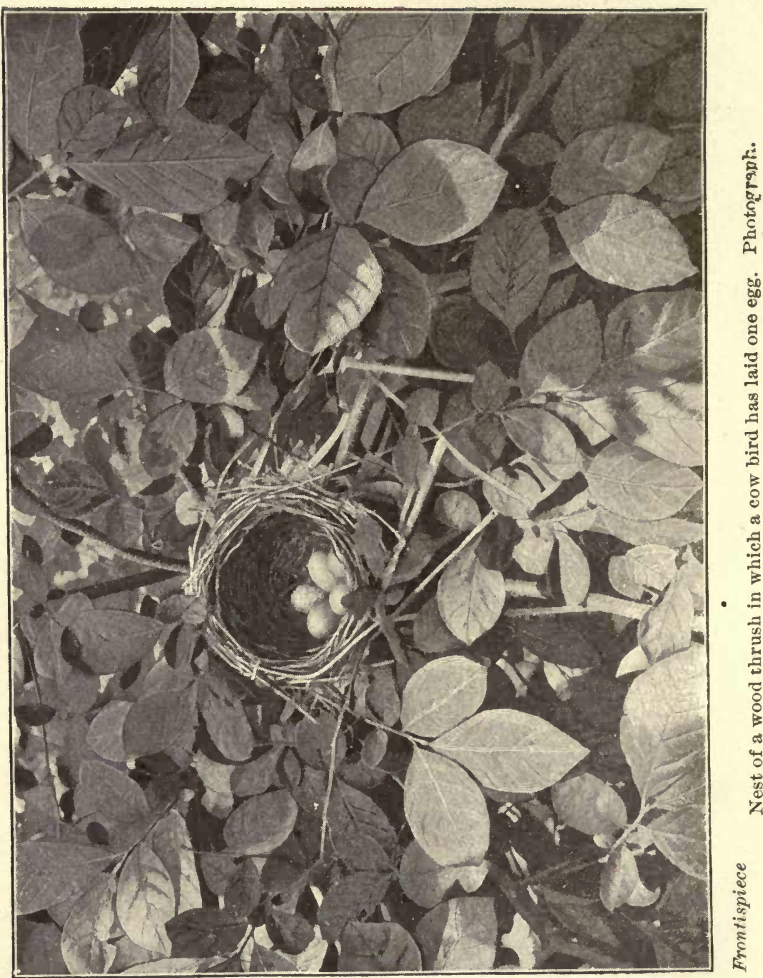




\section{PRACTICAL ZOÖLOGY}

\section{AN ELEMENTARY TEXT-BOOK TREATING OF}

THE STRUCTURE, LIFE HISTORY, AND RELATIONS OF ANIMALS

BY

ALVin DAVisON, A.M., Ph.D.

Professor of Biology in Lafayette College; Fellow of the American Association for the Advancement of Science; Author of Mammalian Anatomy, etc.

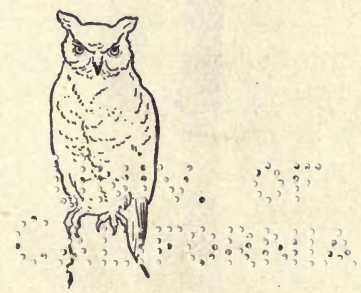

NEW YORK $\therefore$ CINCINNATI $\therefore$ CHICAGO AMERICAN BOOK COMPANY 
$Q<43$
$D 35$

BIOLOGY

LIBRARY

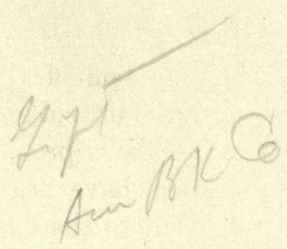

Copyright, 1906,

BY

ALVIN DAVISON

Davison's Zoölogy

w. P. 7

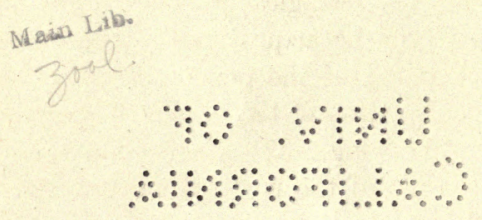




\section{PREF A CE}

IN most cases where only one of the two biologicay branches is included in the curriculum of a secondary school, botany is chosen. This is probably due not only to the fact that few teachers have studied zoölogy, but also to the difficulties incident to the teaching of the subject and the impractical kind of zoölogy to which too many teachers have been introduced. In many schools the college graduate has inflicted on his pupils in their lower teens the zoölogy adapted to college students. Laborious dissections, permitting the details of structure to be noted and wearisome drawings to be made, may be of value to the few, but render injustice to many.

The plan of teaching the biological sciences lately in many schools has sacrificed the acquisition of important information and the training of the powers of reflection and expression to the cultivation of the powers of observation and the teaching of drawing. The average individual cares little about the names of the parts of the crayfish's legs or the veins in the wings of insects, but he must be stupid indeed who is not interested in the interdependence of species, the part played by insects in the transmission of disease, the marvelous life history of the creatures with which he comes into daily contact, and the meaning of the animal architecture so common in the crowded city as well as by the unfrequented wayside. It is far more important 
that the pupils should become acquainted with some of the important works on zoölogy and thus learn where information may be secured on the topics in which they may be interested, than to spend much time in memorizing terms and recording details never to be of any service in later life. The most effective mental discipline is experienced by him who investigates any assigned subject by personal observations of the animals concerned, and by consulting the several pamphlets and books treating of the subject, and then after arranging his information in logical order presents it to the rest of the class in language and drawings sufficiently clear to be comprehended.

The growing custom of allowing the work recorded in the note book to take the place of oral recitation is a bad one. The mental discipline and exhilaration resu'ting from the expression of one's matured thoughts before his associates can be secured in no other way. A number of questions should be assigned the class for each recitation, in addition to one or two special topies to be reported on by one or two members allowed a week or more to investigate them. In some schools the instructor will find it wise to omit certain subjects discussed in the text owing to the need of time for more extended laboratory work and the investigation of topics in which his community may be specially interested.

A comparatively small amount of laboratory work is indicated, and the animals to be used are such as may be secured almost anywhere. Detailed directions concerning the examination and dissection of specimens have been largely omitted in order that the pupil may have some opportunity to think for himself. Moreover, different schools 
are unable to carry on the laboratory work on the same animals with the same degree of thoroughness. Those who are unable to secure any material for study will find in the illustrations excellent substitutes, but it is hoped that every teacher will strive to afford his pupils that mental stimulus and specially valuable mind culture resulting from a face to face acquaintance with animal life. At best, it is impossible to secure all the material necessary to demonstrate the ideas to be taught, and therefore numerous illustrations have been introduced. Much time and expense have been given to the preparation of the photographs, which can be relied on as representing facts more accurately than drawings, and approaching as nearly as possible to nature itself.

The subject matter has been so treated as to adapt the book to schools giving either a half or whole year to the study of zoölogy. Those preferring it can begin the study with the Protozoa and proceed to the higher forms, instead of following the order given in the text, as the chapters in Parts I and II are so written as to be largely independent of each other. Teachers having only a half year for Zoölogy will perhaps find it wise to omit certain chapters in order that the time which ought to be spent in studying the animals shall not be devoted to the study of the book. It is not expected that most schools will be able to give careful attention to all the subjects treated, but the numerous forms and phases of animal life have been presented in order to allow some choice on the part of the teacher desiring to emphasize special features of zoölogical study.

Mr. D. S. Hartline, of the State Normal School at Blooms- 
burg, has rendered me efficient assistance in reading and criticising the entire manuscript, while numerous other students of nature to whom credit is given in the text have contributed drawings, photographs, and suggestions, adding much to the value of the book.

Alvin Davison.

Lafayette College, Easton, Pa. 


\section{CONTENTS}

\section{INTRODUCTION}

PAGR

Methods, EQutpment, EtC . . . . . . . . . . . . . 11

Classification

\section{PART I}

The Arthropoda: Segmented Forms with Jointed Legs

1. Orthoptera .................. 30

2. DipterA . . . . . . . . . . . . . . 39

3. Hymenoptera ................ 52

4. LePIdopterA . . . . . . . . . . . . . . 68

5. Hemiptera . . . . . . . . . . . . . . . 91

6. Coleoptera . . . . . . . . . . . . 107

7. Neuroptera, Ephemerida, and Odonata . . . . 116

8. Arachnida and Mrriapoda ......... 125

9. Crustacea .................. 133

\section{PART II}

The Anarthropoda: Invertebrates without Jointed Legs

10. Mollusca . . . . . . . . . . 142

11. Vermes ............... . . 150

12. Echinodermata ................... 161

13. Celenterata and Porifera . . . . . . . . . 167

14. Protozoa: One-cellled Microscopic Animals . . . 178 


\section{CONTENTS}

\section{PART III}

\section{Vertebrata}

15. Pisces ...................... 185

16. АмрнівіА .................. 199

17. Reptilia ................. . . 211

18. Aves . . . . . . . . . . . . . . 226

19. Mammalia ............... 261

\section{PART IV}

Animal Life

20. From EgG to Adult ............. 293

21. Senses of Animals . . . . . . . . . . . . 303

22. Protection from Enemies. . . . . . . . . . 310

23. Parasitism ................. . . . 323

24. VAnishing Species . . . . . . . . . . . . . . . . 334

25. Origin of the Diverse Forms of Animal Life . . . 342 


\section{INTRODUCTION}

\section{METHODS, EQUIPMENT, ETC.}

The Biological Sciences. - All living things belong either to the plant or to the animal kingdom. An individual of either group is termed an organism. A study of the animal organisms constitutes the science of zoölogy, while botany has for its field the investigation of plant life. The science of biology includes both botany and zoölogy.

Any animal or plant may be considered from several different standpoints. A general study of structure and of the relations of the various systems and organs is known as anatomy. The location and parts of the heart and courses of the nerves and blood vessels are questions belonging to this science. Physiology has for its province the investigation of the functions of the organs and systems, and therefore explains the uses of the heart, lungs, and blood vessels. Inquiries relating to the home life, food, enemies, and external appearance of animals belong to the domain of Natural History, which also concerns itself with the same phases of plant life.

Value of Zoölogical Study. - It is proper that both teacher and pupil should keep in mind the advantages to be derived from the study of animal life, that time may not be wasted on insignificant details. In fact it is the duty of every teacher to present only such portions of a science as 
will be of the greatest economic, educational, and ethical value to the learners.

Economic Zoölogy has lately proved itself worthy of the consideration of every American citizen. The number of injurious insects in the United States is large and increasing. They often destroy one fourth or even a half, and sometimes the entire crop of a whole section. The agricultural products of our country amount annually to about $\$ 3,000,000,000$, while the loss of crops from the attacks of insects is estimated at $\$ 100,000,000$. In 1874 in the Western states, the Rocky Mountain locust caused over $\$ 40,000,000$ of damage. The chinch bug (Fig. 116) in Illinois, during the year 1864 , destroyed $\$ 70,000,000$ worth of crops, and in Missouri ten years later was responsible for the loss of nearly $\$ 20,000,000$ worth of produce. The governor of Texas recently made an offer of $\$ 50,000$ to any one who should discover a remedy for the ravages of the cotton-boll weevil (Fig. 121). The San Jose scale (Fig. 107) destroys acres of valuable fruit orchards annually. A much greater loss to crops would result yearly were it not for the fact that men have learned by the study of zoölogy how to control some of the insect pests, and also how to secure the greatest benefits from birds and a large class of insects naturally helpful to man. Ignorance concerning the food of hawks and owls caused the Pennsylvania legislators in 1885 to pass a law resulting in a loss to the state of $\$ 2,000,000$. By becoming acquainted with the habits of animals, man is able to have dominion over them, and by wise legislation to make such laws in regard to their destruction or preservation as will be to the best interests of not only the present but future generations. 
The Educational Value of zoölogical studies can not be overestimated. They furnish the means of bringing nature and the child into direct contact, so that he may actually acquire some knowledge by his own powers of perception. Froebel says, "We do not feel the meaning of what we say, for our speech is made up of memorized ideas based neither on perception nor on productive effort."

Animal life properly studied develops not only the faculties of acquisition, but likewise the powers of reflection or reasoning and expression. Essay writing and memoriter recitations are too often wearisome, but if the pupil has learned something of vital interest concerning an animal's life history, habits, and struggle for existence, he will find pleasure in relating his discoveries to his classmates, and thereby will experience a splendid training in the use of intelligent English.

The Ethical Value to be derived from the study of zoölogy depends largely on how the subject is taught. Much evil is wrought in our land through ignorance. Youth seldom stop to think how much harm is done when they ruthlessly destroy life. The maiming of a single bird may mean death to many little ones. A careful estimate shows that only about half as many birds exist to-day as were present in our country a quarter of a century ago. One chief factor causing the decrease has been ignorance on the part of the people who have sanctioned the robbing of nests and killing of birds. Every boy and girl should go forth from school imbued with the idea that the killing of our best friends in the animal world merely to satisfy a savage instinct is a crime. A face to face acquaintance with the creatures of earth should gain many warm ad- 
vocates of the Society for the Prevention of Cruelty to Animals. Moreover, to him who understands the meaning of the well-woven nest by the roadside, the glistening eggs on the tender twig, and the thousand other sights and sounds of the lane and park, there is no nook or cranny of creation without a wholesome interest.

\section{EQUIPMENT}

Plan of Work. - It is not important that the pupils should learn many things, but it is important that they should be taught to observe accurately, to reason carefully, and to express their thoughts in clear English. The teacher will be asked many questions about animals, which he can not answer, and therefore he must realize there is no disgrace in saying; "I do not know, but let us together seek the information in the books and in the animals themselves." Pupils should be encouraged to ask questions, and those which can not be easily answered may be assigned to one or more individuals for study during the next several days. Agassiz's motto, "Study nature, not books," ought to hang in every schoolroom. This text-book is not to be memorized; it aims merely to furnish to inquiring minds information about animals.

If the class becomes specially interested in scale insects and plant lice, or birds and insects, or mosquitoes and other flies, it is wise to devote much time to these and give less study to other forms. Many teachers will find it wise to omit certain chapters and some parts of other chapters, to save time. 
Each instructor should choose those subjects for which he can most easily secure the material, and if possible study the various forms of life during that season of the year when they are most active. Insects are best studied in the autumn, the birds in early summer, the reptiles and amphibians in early spring, and the lower invertebrates and mammals in winter. If only one term is devoted to zoölogy fewer reference books will be required and a smaller number of animals should be considered.

As in most cases it is impossible to observe out of doors all the stages in the life history of a species, pupils must learn to study carefully the illustrations in the book and also make use of well-preserved specimens.

Preservation of Material. - Nothing else will create so much interest in this branch as the collection and preservation of animals to be used not only by the present but also by future classes. Nearly all insects in the adult state may be preserved by merely allowing them to dry in the air five or six days after the legs and wings have been arranged and pinned in the desired positions.

A pine board to which are tacked two or three sheets of blotting paper makes a good pinning board. If the wings are to be spread the insect should be laid on its back, otherwise it may be placed in its natural position. In either case pins should be so stuck as to hold all parts without penetrating the animal.

Dried material will be destroyed by museum pests unless placed in tight boxes, which can be made by any boy or girl. Secure two panes of glass of equal size. If they measure eight by ten inches, saw from a thin board four strips a half inch wide, and make two of them eight inches 
long and the other two nine inches, so that when put together they will form the sides of the box whose top and bottom are the panes of glass. With mucilage or royal

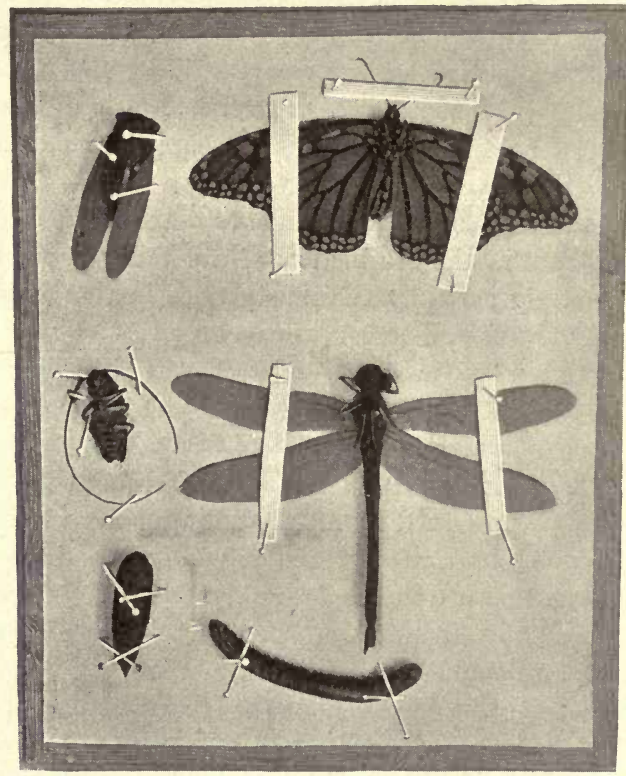

FIG. 1. - Pinning board. Strips of paper hold the wings. $a$, Cicada; $b$, butterfly ; $c$, wood-boring beetle; $d$, dragon fly; $e$, pupa of hawk moth; $f$, galley worm.

glue cement the strips to one pane and let them dry over night, keeping them pressed closely to the glass by the weight of a heavy book. In place of wood, seven or eight strips of thick pasteboard glued one on top of anot'er 


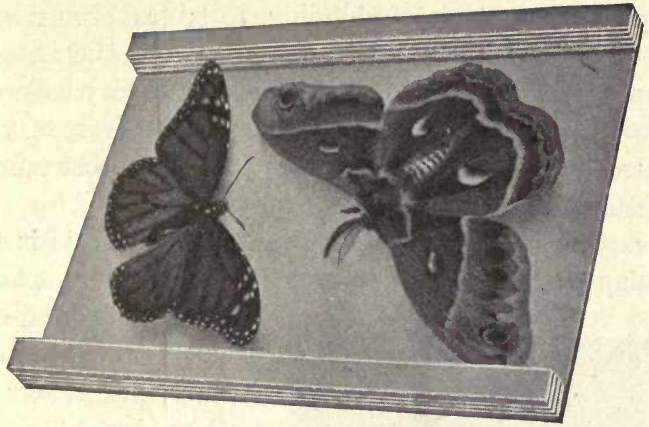

FrG. 2.- First step in making an insect cabinet.

may serve for the sides of the box. At any time later, the insects may by a drop of glue be stuck to the pane form-

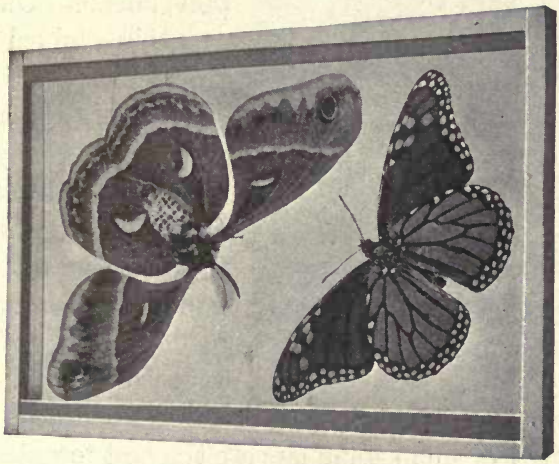

FIG. 3. - Cabinet 5 by 7 inches completed. Cost, six cents.

ing the bottom of the box and then the top pane glued on. A neat appearance can be given the cabinet by edging it 
with passe-partout picture binding, to be had at any bookstore or photographic supply house. If one such cabinet is prepared each year, a valuable natural history collection will soon result. The centipeds and spiders may be mounted in the same manner as insects, but other animals are better preserved in alcohol or formalin.

A very neat method of mounting small insects is that of gluing the specimens to a piece of glass and placing

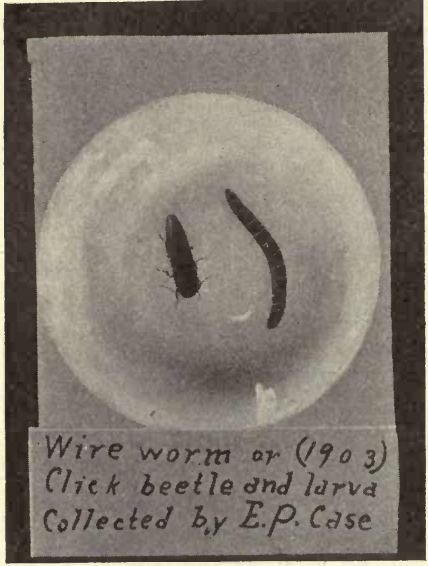

Fig. 4. - Watch-crystal mount. over them a watch crystal held in place by a few drops of glue.

Pure formalin or formaldehyde may be purchased at the drug store for about fifty cents per pint bottle. One part of this mixed with twenty parts of water makes a solution that will preserve any plant or animal. In case the animal is large, such as a snake or rat, one or two long slits should be made in the abdominal wall so that the fluid may reach the internal organs. Wide-mouthed bottles and fruit jars or small stone jars are the best receptacles for these specimens.

Painless death may be effected in a half hour by placing any animal in a tight jar or box with a bunch of cotton or 
cloth on which have been placed thirty or forty drops of chloroform for every hundred cubic inches of space. A convenient killing jar for insects is made by having a druggist place in a wide-mouthed fruit jar five cents' worth of potassium cyanide in small pieces, which must be covered with a thick solution of plaster of Paris in water. In order that the plaster may dry the jar should be left open a day or two and then kept closed except when putting in or removing animals. Potassium cyanide is a deadly poison. A wide-mouthed cyanide bottle is convenient for pupils to use in the field.

Keeping Live Animals. - With but slight trouble and great profit many animals may be kept alive in the school room or laboratory. Snakes, turtles, and lizards live comfortably in a covered box containing dry earth and a soup plate with water. A turtle will eat fresh beef, but the lizard and snake need a weekly meal of beetles, flies, or earthworms. Tadpoles, newts, fish, water fleas, various insect larvæ, a few worms, hydra, and many protozoans flourish in aquaria consisting of glass jars or dishes filled with water and containing a few water plants. The water need not be changed if the bulk of the plants is about one fourth that of the animals. A few bits of fresh beef should be given the vertebrates once a week. The aquarium needs good light but not necessarily direct sunshine in order that the plants may flourish and furnish oxygen for the animals. Gallon battery jars to be had of the Whitall, Tatum Co., of New York, serve excellent aquarium purposes and cost but fifteen cents each.

If animals which one can not secure in his own locality are desired, they may be obtained of the following dealers: 
American Entomological Company, 1040 DeKalb Ave., Brooklyn, N. Y. All kinds of insects. Catalogue on application.

Brimley Bros., Raleigh, N. C. Living and preserved animals.

Biological Laboratory, Cold Spring Harbor, L. I., N. Y. Marine animals. Catalogue on application. Tufts College Laboratory, South Harpswell, Me. Hopkins Seaside Laboratory, Stanford University, Cal.
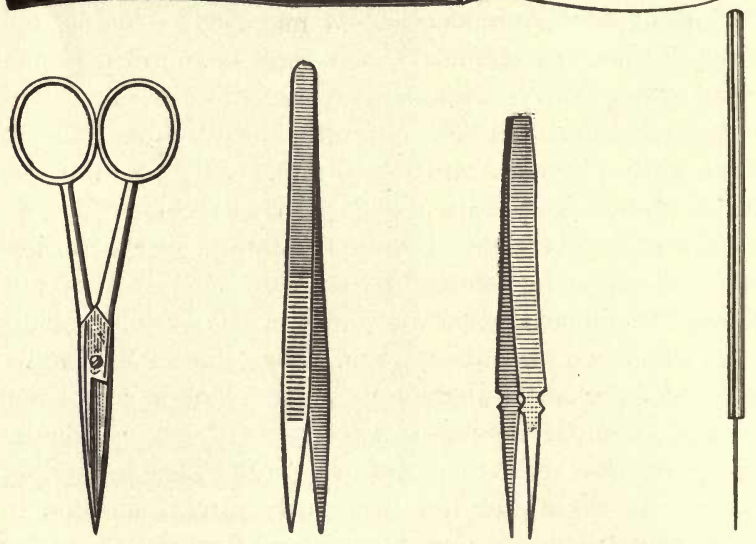

FTG. 5. - Dissecting instruments.

St. Louis Biological Laboratory, St. Louis, Mo. Numerous kinds of animals and microscopical slides showing structure of animals. Catalogue on application.

The Laboratory. - This should be a well-lighted room 
containing a number of tables with drawers for the use of the pupils, and several shelves or cases for holding preserved material. If such a workroom is not available two or three tables placed in the schoolroom will be found of great use. For those who wish to do much in the line of dissection a few thirty-five cent scalpels, or dissecting knives, forceps, needles, scissors, and trays both of tin and wood are necessary. The bottoms of the tin trays should be covered with a quarter-inch layer of melted paraffine to which the small animals are to be pinned while being dissected under water.

At least one or two compound microscopes are necessary. A satisfactory instrument can be purchased for about \$30. A few dissecting microscopes costing about $\$ 2.50$ each are of service in the study of many forms.

A half gross of glass object slides and a half ounce of number two cover glasses are required for the examination of microscopic objects. A bottle of chloroform and a quarter of an ounce of chloretone dissolved in a quart of water should be ready for use as described in the special lessons.

Books. - The pupils in addition to their text-books will take an interest in consulting the following references if they are accessible:

Apgar, A. C.: Birds of the United States. American Book Company. \$2.00. Will help one to identify the birds in the hand or in the field.

* Bergen, J. Y. and F. D: A primer of Darwinism and Organic Evolution. Lee \& Shepard. Boston. \$1.25. Explains how species have originated.

*Blanchan, Neltje: Bird Neighbors. Doubleday, Page \& Company. New York. \$2.00. Contains colored plates and enables one to identify one hundred and fifty birds in the field. 
Burnet, Margaretta: Zoölogy for High Schools and Academies. American Book Company.

*Chapman, F. M.: Bird-Life. D. Appleton \& Company. New York. \$1.75. A good book for beginners.

Davenport, C. B. and G. C: Introduction to Zoölogy. Macmillan \& Company. New York. \$1.10.

Davison, Alvin: Mammalian Anatomy. P. Blakiston's Son \& Company. Philadelphia. \$1.50. Treats of the preparation and preservation of mammals for dissection and their anatomy. Valuable for a teacher of physiology.

DodGe, C. W.: General Zoölogy. American Book Company. New York.

Hornaday, W. T.: American Natural History. Charles Scribner's Sons. New York. \$3.50. Treats of vertebrates only.

*Ingersoll, E.: Nature's Calendar. Harper and Brothers. New York. \$1.50. Contains practical suggestions for outdoor observations.

JoRDAN, D. S.: Manual of Vertebrate Animals of Northern United States. McClurg \& Company. Chicago. \$2.50. Enables one to identify any vertebrate.

KInGsueY, J. S.: Elements of Comparative Zoölogy. Henry Holt \& Company. New York. \$1.20.

LeConte, J.: Evolution and its Relation to Religious Thought. D. Appleton \& Company. New York. \$1.50.

*Lucas, F. A.: Animals of the Past. McClure, Phillips \& Company. New York. \$2.00. A popular account of fossil remains. Marshall, C. M. and Hurst, C. H.: Practical Zoölogy. G. P. Putnam. New York. \$3.50. Directions are given for dissecting rabbit, pigeon, dogfish, and other forms.

*Needham, J. G.: Outdoor Studies. American Book Company. New York. \$.40.

Parker, T. J. and Haswell: Text-book of Zoölogy. Macmillan \& Company. New York. $\$ 9.00$. A thorough and clear treatise.

*Sanderson, E. D.: Insects Injurious to Staple Crops. Wiley \& Company. New York. \$1.50. 
*Stokes, A. C.: Aquatic Microscopy for Beginners. E. F. Bigelow. Portland, Connecticut. \$1.25. Useful in identifying small water animals.

*Weed, C. M. and Dearborn, N.: Birds in their Relation to Man. J. P. Lippincott \& Company. Philadelphia. A valuable book. The books in the above list marked with an asterisk will be found most valuable for elementary work.

Every school will find interesting and valuable information in the Yearbooks of the Department of Agriculture which may be had free of charge by applying to the United States senator or representative of the district in which the school is located. Back numbers may be had at second-hand book stores for about twenty cents each.

The following useful bulletins and circulars will be sent free upon application to the Secretary of Agriculture, Washington, D. C.

Some Insects Injurious to Stored Grain, pp. 24, figs. 18.

Insects Affecting the Cotton Plant, pp. 32, figs. 18.

Some Common Birds in Their Relation to Agriculture, pp. 48. Bee Keeping, pp. 32, figs. 19.

The Principal Insect Enemies of the Grape, pp. 23, figs. 12.

The Peach Twig-Borer, pp. 16, figs. 5.

Three Insect Enemies of Shade Trees, pp. 30, figs. 11.

The Principal Insects Affecting the Tobacco Plant, pp. 32, figs. 25.

Important Insecticides, pp. 42, figs. 6 .

The Principal Insect Enemies of Growing Wheat, pp. 40, figs. 25. How Insects Affect Health in Rural Districts, pp. 20, figs. 16.

Silk Worm Culture, pp. 32, figs. 15.

The Control of the Coddling Moth, pp. 24, figs. 4.

Scale Insects and Mites on Citrus Trees, pp. 43, figs. 34 .

Insects Injurious in Cranberry Culture, pp. 32, figs. 12.

Information concerning the Cotton Boll Weevil, pp. 31, figs. 8.

The Cotton Boll Worm, pp. 24, figs. 7.

Usefulness of the Toad, pp. 16.

Reindeer and Caribou, pp. 14, pls. 7.

Bird Day in the Schools, pp. 4. 
The Hop Plant Louse, pp. 7, figs. 6.

The Army Worm, pp. 5, figs. 3.

The Carpet Beetle, or Buffalo Moth, pp. 4, fig. 1.

Canker Worms, pp. 4 , figs. 4.

Mosquitoes and Fleas, pp. 6.

The Strawberry Weevil, pp. 7, figs. 4.

The Ox Warble, pp. 10, figs. 10.

The Pear Slug, pp. 7, figs. 4.

The Fruit-tree Bark-Beetle, pp. 8, figs. 4.

The Striped Cucumber Beetle, pp. 7, figs. 2.

The Larger Apple.Tree Borers, pp. 12, figs. 3.

House Ants, pp. 4, figs. 3.

House Flies, pp. 8, figs. 8.

The True Clothes Moth, pp. 8, figs. 3.

The Common Squash Bug, pp. 5, figs. 3.

How to I)istinguish the Different Mosquitoes of America, pp. 8.

The Bed-bug, pp. 8, figs. 3 .

The House Centipede, pp. 4, figs. 2.

The Silver Fish, pp. 4, figs. 2.

Cockroaches, pp. 15, figs. 5 .

The Peach Tree Borer, pp. 6, fig. 1.

Four Common Birds of the Farm and Garden, pp. 14, figs. 4. The Meadow Lark and Baltimore Oriole, pp. 12, figs. 2.

Asparagus Beetles, pp. 12, figs. 6.

Insects Injurious to Beans and Peas, pp. 28, figs. 17.

The Food of Nestling Birds, pp. 26, figs. 14.

Smyrna Fig Culture in the United States, pp. 28, figs. 15.

How Birds Affect the Orchard, pp. 14, figs. 5.

Insects as Carriers and Spreaders of Disease, pp. 16, figs. 15.

The San Jose Scale: Home and Natural Enemies, pp. 20, figs. 9.

Insects Injurious to Hardwood Forests, pp. 16, figs. 17.

Audubon Societies in Relation to the Farmer, pp. 14, figs. 4.

Some New Facts about the Migration of Birds, pp. 16, figs. 2.

A monthly list of publications by the United States Government may be had free of charge by sending the request to the Secretary of Agriculture, Washington, D. C. 


\section{CLASSIFICATION}

For the sake of convenience in discussing the characteristics of animals the entire kingdom is divided into subkingdoms, classes, orders, families, and species, as given in the following outline. It is not intended that this incomplete table of classification should be memorized, but rather that the pupils should become familiar with it as indicated in the practical questions by constant reference to it throughout the term.

SubKINGDom

I. РRōtozō'A (first animals): Single-celled aquatic animals of microscopic size. Ameba and Paramœcium (Figs. 211, 209).

SubKingdom SubKingdom

II. PorǏF'terA (pore bearers): Sponges.

III. Ceelentera'ta (hollow within): Aquatic mostly marine animals having but one internal cavity. Jellyfish, coral builders, and hydroids (Figs. 203, 199).

Subkingdom IV. Phätyhelmín'thes (flatworms): Worms with flattened bodies and no cavity surrounding the alimentary canal. Tapeworms and liver fluke (Fig. 184).

Subkingdom V. Nemathelmin'thes (thread worms): Round worms with no external evidence of segments. Horsehair worm and vinegar eel (Fig. 183).

Subringdom VI. Trochelmin'thes (wheel worms): Minute aquatic worms with cilia about the mouth. Rotifer.

Subringdom VII. Molluscoi'da (like a mollusk): Aquatic worms usually living in colonies. Sea mats. Subringdom VIII. Ěchinoder'mata (spiny skinned): Marine radiate forms often covered with spines. Starfish and sea urchin (Figs. 187, 190). 
SubKINGdom

SuBKINGDOM

Subringdom X. Mŏllus'ca (soft): Soft-bodied forms usually

IX. ANNula'ta (with rings): Worms with segments apparent externally. Earth worm and leech (Figs. 178, 179). with a shell. Oysters, snails, slug, squid.

XI. Arthró'poda (jointed feet): Segmented forms with jointed legs. Crabs, beetles, wasps.

Class 1. Crŭstā'cea (crust): Arthropoda with head and thorax fused and usually a hard outer skeleton. Crayfish (Fig. 155), lobster, pill bug (Fig. 164).

Class 2. Myria'poda (thousand-footed): Forms with air tubes throughout the body and numerous legs. Centipeds (Fig. 152), millepeds (Fig. 153).

Class 3. Arach'nida (spider): Forms with usually four pairs of legs and no antennæ. Spiders, scorpions (Figs. 144-151).

Class 4. Insěc'ta (cut-in): Forms with body showing three distinct parts called head, thorax, and abdomen ; and breathing by means of tubes ramifying among the tissues and opening on the lateral aspect of the body (Figs. 9, 10).

Order a. Ephemer'ida (lasting one day): Forms with two unequal pairs of wings, no mouth parts, and two or three filaments projecting from the end of the abdomen. May fly (Fig. 139). Order b. Odona'ta (tooth) : Forms with four nearly equal membranous wings. Dragon flies, damsel flies (Figs. 140, 141). Order c. Orthop'tera (straight-winged): Forms usually with four wings, the hinder ones being thin and overlapped by the thick fore wings when at rest. Grasshoppers, crickets, cockroaches (Figs. 11, 13).

Order d. Hemı̌p'tera (half-winged): Forms which take food by sucking only. Bedbug, cicada, plant lice, scale insects (Figs. 98, 107).

Order e. Neurop'tera (nerve-winged): Forms with two pairs of membranous net-veined wings. Dobson or hellgramite (Fig. 138).

Order f. Lepidop'tera (scale-winged): Forms with two pairs of wings covered with overlapping scales. Butterflies, moths, millers. 
Order g. Dip'tera (two-winged): Forms with only one pair of wings and behind them a pair of short-knobbed processes, the halteres. Flies and mosquitoes.

Order h. Côleop'tera (shield-winged) : Forms with a pair of horny wing covers and a single pair of membranous wings. Beetles.

Order i. Hymenop'tera (membrane-winged): Forms with two pairs of membranous wings, mouth parts for both biting and sucking, and the female usually with a sting, pierce, or saw. Ants, bees, wasps (Figs. 32, 36).

Subringdom XII. Protochorda'ta (first cord): Marine animals forming a connecting link between the vertebrates and invertebrates. Sea-squirts, lancelet.

Subkingdom XIII. Vertebra'ta (turning): Forms with a skeletal axis and a dorsal nerve cord whose anterior end is dilated into a brain.

Class 1. Pissces (fish): Aquatic cold-blooded forms with gills and usually paired fins, but not legs.

Class 2. Amphỉ'ia (both lives): Cold-blooded forms without scales, usually with two pairs of legs, and breathing by gills in early life. Frogs, salamanders, toads (Figs. 230, 231).

Class 3. Reptrl'ia (to creep): Cold-blooded forms with scales and lungs. Snakes, lizards, turtles.

Class 4. A'ves (birds): Warm-blooded vertebrates with feathers. Class 5. Mammã'lia (with breasts): Hairy vertebrates suckling their young. Dog, monkeys, man.

Order a. Monotre'mata (single opening): Egg-laying mammals. Duck mole, spiny ant-eater (Figs. 297, 300).

Order b. Marsūpia'lia (pouch): Mammals whose young at birth are very small and immature and are therefore placed in an abdominal pouch to be nourished several weeks. Opossums, kangaroos (Figs. 299, 298).

Order c. Inséctǐv'ora (insect eaters): Mammals living largely on insects. Shrews, moles (Fig. 311).

Order d. Edenta'ta (without teeth): Forms in which the teeth are often wanting and if present there is no enamel. Sloths, ant-eaters. 
Order e. Chirŏp'tera (hand-winged): Forms adapted for flight. Bats, flying foxes (Fig. 310).

Order f. Roden'tia (gnawing): Mammals having usually two elongated chisel-like incisors in each jaw. Rabbits, squirrels, mice, rats (Fig. 309).

Order g. Cetā'cea (whale): Marine mammals with fishlike body and no hind limbs. Whales, porpoises, dolphins.

Order h. Sirēn'ia (siren): Aquatic forms with no hind limbs. Sea cow.

Order i. Ungula'ta (bearing hoofs): Mammals which have hoofed feet. Horse, cow, pig.

Order j. Carntv'ora (flesh-eating): Mammals living on flesh and with strong canine teeth and claws. Dogs, cats, wolves, foxes.

Order k. Primates (first): Mammals with thumb opposable to the other digits. Lemurs, monkeys, man.

A glance at the above outline shows that the entire animal kingdom, consisting of a half million species, is divided into thirteen subkingdoms sometimes called phyla or branches. Each of these is composed of several classes, but in most cases the names of the classes are not given. The divisions of the classes are designated orders which in turn are divided into families. A family is composed usually of several genera, and each genus is still further divided into species.

Linnæus of Sweden invented the system of binomia: nomenclature, in accordance with which the name of every plant or animal is composed of two parts, the generic which is a noun, and the specific, which is an adjective. Thus, the house cat is called Felis domestica; the lion. Felis leo; the dog, Canis familiaris; the wolf, Canis latrans; the red squirrel, Sciurus hudsonicus; the gray squirrel, Sciurus carolinensis. Animals of the same genus but of 
different species resemble each other much closer than do animals of two different families, and still fewer characters are common to animals belonging to different orders. Thus, the horse, Equus caba'lus, and the ass, Equus asinus, differ chiefly as to the tail and ears only. Both belong to the order Ungulata and family Equidae. The cow, Bos taurus, of the same order but of the family Bovidoe, differs much from the horse and ass in possessing shorter legs with two toes, a pair of horns, and no upper incisor, or canine teeth. The black bear, Ursus americanus, presents great contrast in structure to the above animals and is therefore placed in another order, Carnivora. It feeds on flesh, has teeth adapted to cutting instead of grinding, and claws in place of hoofs.

Since a fish resembles the above animals in having a back bone, a brain, and nerve cord on the dorsal side it is placed in the same subkingdom, Vertebrata, but must be assigned to another class, $P$ isces, on account of the absence of hair, limbs, lungs, and other features common to the mammals. 


\section{PART I}

\section{ARTHROPODA: SEGMENTED FORMS WITH JOINTED LEGS}

\section{ORTHOPTERA}

THE majority of the species of animals belong to the branch Arthropoda. A feature distinguishing this group from all other invertebrates is the presence of jointed legs. These, however, may be absent in a few forms leading a parasitic life (Fig. 150). Of the four classes of Arthropoda, the insects, numbering over three hundred thousand

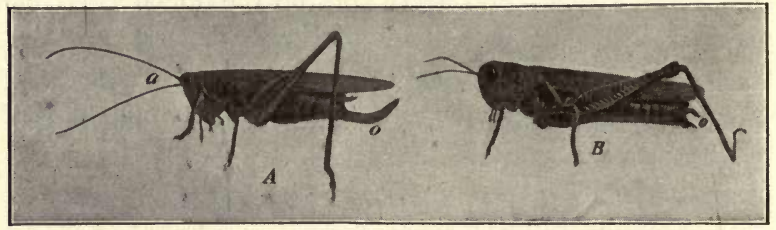

FiG. 6. $-A$, Long-horned grasshopper; $B$, Locust; $a$, antennæ ; $o$, ovipositor.

species, are the most important because among them are found man's greatest enemies as well as valuable helpers.

\section{Locusts}

The locusts, commonly called grasshoppers, include about three hundred different species, but only three or four kinds are easily found in any one locality. Only the short-horned 
grasshoppers (Acridi'ida), which means those having antennæ half the length of the body, or less, are true locusts. Those with antennæ nearly as long as the body, or longer, are the true grasshoppers (Locustida). Such is the katydid (Microcentrum retinervis), which is more than an inch long and has wings so veined and colored as to resemble a green leaf.

Habits. - In most cases the eggs of the locust, numbering from ten to a hundred and having somewhat the form of grains of wheat, are laid during July or August in the soil. They are held together in irregular masses by a cement. The majority of the species pass the winter in the egg state, but the large American locust, or bird grass-

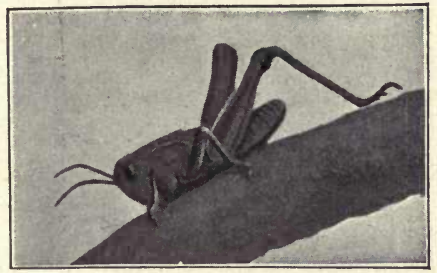

Fig. 7. - Locust about two weeks old. Photograph twice natural size. hopper of our southern states, hibernates as an adult. The young locusts, called nymphs, emerge from the eggs hidden a half inch or more in the soil, during early summer. Forms from a fourth of an inch to a half inch long and wingless may be found in abundance in the grassy fields during May and June. If some of these are caught and fed with grass daily for a week or two the observer may have the rare pleasure of seeing the insect molt, i.e., shed its skin. Most insects molt during their growth period from three to six times.

After the locust's first molt the wing pads appear as tiny projections, and after the third molt they are quite 
conspicuous, but they do not serve for flight till after the last molt, when the insect is said to have completed its transformation from the nymph to the adult state. In most regions the mature insects may be found in grassy fields from July till frost appears.

External Features. - The food of the locusts is almost any kind of green herbs, which they bite off with a pair of

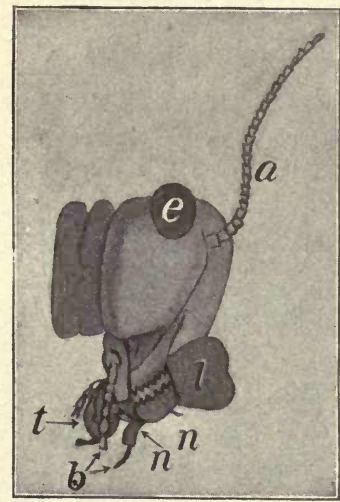

Fig. 8.- Mouth parts of a locust. $a$, antenna ; $l$, labrum turned forward to expose the mandibles, $m$; $n$, maxilla reflected; $b$, palpi of the maxilla; $t$, labium. Twice natural size. Drawing by Reese. hard lateral moving mandibles. An examination of the mouth region shows an upper lip or labrum covering the front side of the mandibles, which are easily recognized by their hardness and serrated inner margins. Behind these is a pair of maxillo divided into three lobes, the outer and longer of which is the feeler, or palpus. Next in order is the lower lip, or labium, apparently composed of two lateral halves, each bearing a palpus. Most biting insects present mouth parts similar to these. The mosquitoes and some flies and bugs have piercing but not biting mouth parts.

The locust's body is divided into three parts: the head, bearing a pair of many-jointed antenno; the thorax, supporting three pairs of legs and two pairs of wings, the anterior of which are parchmentlike and serve to cover the posterior which are membranous and folded longitudinally 
Like a fan when the insect is at rest; and the abdomen, which in the female terminates in two pairs of sharp-hooked spines forming the ovipositor or egg-depositing apparatus. The thorax and abdomen are composed of ringlike portions, called somites, of which the three in the thorax are named prothorax, mesothorax, and metathorax. The part of the somite on top is the tergum, that underneath is the sternum, and on the sides are the pleura. Eleven somites

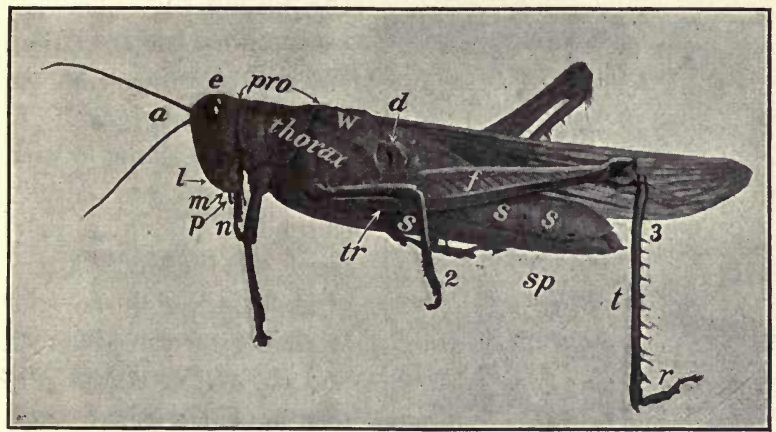

FIG. 9. - Locust with the left wing $w$ eut off near the base. $a$, antennæ; $d$, ear; $e$, compound eye ; $f$, femur ; $l$, labrum ; $m$, maxilla ; $n$, front leg of right side; $o$, mandible; $p$, palpus of right maxilla; $r$, tarsus; $s$, segments of the abdomen; $t$, tibia ; $t r$, trochanter; photograph, natural size.

are present in the abdomen, and the dorsal (upper) and ventral (under) part of each is composed of a single plate named the tergite and sternite, respectively. The sternites of the last three somites are wanting in the female.

Each leg is composed of a short proximal segment, the trochanter; a second segment, stout and long, known as the femur; a third segment, long and slender, called tibia, and a terminal portion made of several pieces forming the 
tarsus. Between the two claws at the end of the tarsus is a little pad, the pulvillus, which enables the animal to walk on smooth surfaces. Directly behind the bases of the antennæ are the two large compound eyes composed of hundreds of cones whose ends, called facets, may be seen on the surface with a good hand lens or low power of the compound microscope. Three ocelli, or simple eyes, well seen with a hand lens, are also present. As in most insects, the median one is between

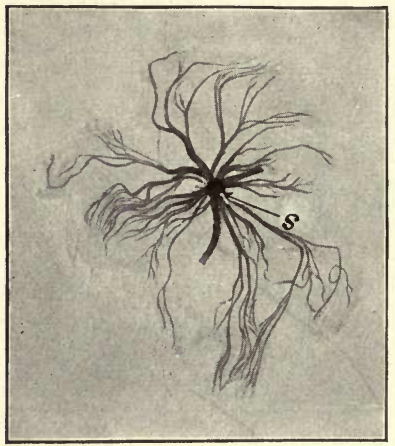

Fra. 10. - Photograph of a spiracle with

its tracher removed from an insect. 8, spiracle. Three times natural size.

the antennæ and the lateral ones just in front of the compound eyes. The ear is a circular opening covered by membrane on the side of the first abdominal segment. On the lateral aspect of each of the eight anterior segments of the abdomen and the two posterior segments of the thorax is a minute opening barely visible to the naked eye. It is the spiracle, which admits air to a tube branching profusely among the tissues for the purpose of supplying all parts with oxygen and carrying away the carbon dioxide formed in every region of an animal's body. These ramifying tubes, called trachece, are common to all insects and a few other Arthropoda.

Destruction of Crops. - Locusts have always been a great pest to man, as may be inferred from the destructive 
powers of the insects frequently mentioned in the Scriptures. Williamson's History of Maine says: "In 1749 and 1754 they were very numerous; no vegetables escaped these greedy troops; they even devoured the potato tops; and in 1743 and 1756 they covered the whole country and threatened to devour every green thing. Indeed, so great was the alarm they occasioned among the people, that days of fasting and prayer were appointed." In 1838 the common red-legged locust (Melanoplus femur-rubrum) was so abundant in parts of Maryland that the negroes were employed to drive them from the gardens with rods.

The most injurious species occurring in this country is the Rocky Mountain locust (Melanoplus spretus) or migratory locust. From 1874 to 1876 they damaged western agriculture, especially in Kansas, Colorado, Nebraska, and Missouri, to the extent of over two hundred million dollars. The government appointed a special committee to devise a remedy to exterminate or check the pest, and numerous plans for destroying the eggs, young, and adults were brought forward. In Minnesota one farmer collected during the latter part of June about eight hundred bushels, by dragging with horses across the grain fields after dark a large box with the front side removed so as to allow the insects to tumble in. Another farmer in the same manner captured four hundred bushels. Some counties paid a reward for locusts collected and killed. In 1875 Nicollet County, Minnesota, paid a dollar per bushel for 25,053 bushels of locusts. Fortunately the insects appear in large numbers only at intervals of from five to twenty or more years, according to the condition of the weather and the presence of enemies. The Rocky 
Mountain locust is always present in greater or less numbers in Montana and parts of Dakota, Wyoming, Colorado, Utah, Idaho, and Oregon. On certain occasions swarms of many millions migrate to the adjacent states, being driven by the wind as they hold

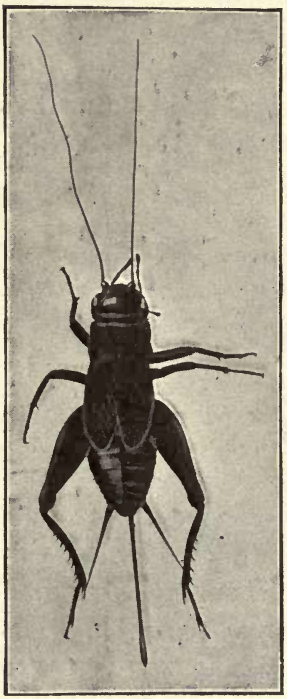

FIG. 11. - Photograph of the common black cricket (Gryllus abbreviatus). Natural size. the wings expanded, but they have never been found east of the Mississippi River. The Carolina locust (Dissosteira carolina), the large gray species frequenting the roadside everywhere in late summer, and recognized by its yellowbordered hind wings, seldom becomes so numerous as to cause much damage.

\section{The Black Cricket}

The short-winged black cricket (Gryllus abbreviatus) is a common autumn insect in every pasture and may frequently be found un. der boards and stones as late as December. The female is distinguished from the male by the long ovipositor projecting from the end of the abdomen, through which eggs pass into holes made in the ground. Here they remain from fall until spring, when the little crickets emerge in the nymph stage without wings. The crickets are celebrated for their high-pitched chirping, produced by the male only, by elevating over the back 
and rubbing together the two wing covers or outer wings on the bases of which are roughened portions. The rate of chirping is according to the temperature of the air. The formula, temperature $=50+\frac{\text { chirps per minute }-40}{4}$ will enable any one to know how high the mercury stands. The sounds made by the male locusts are produced in some species by rubbing the hind legs against the outer wings and in others by rubbing together the upper surface of the front edge of either hind wing and the under surface of a wing cover. All the high shrill notes of the upland heard on dull days and in the evening are produced by the crickets, grasshoppers, or locusts on whose legs or wings the rough surfaces occur. The cricketfeeds on grass,

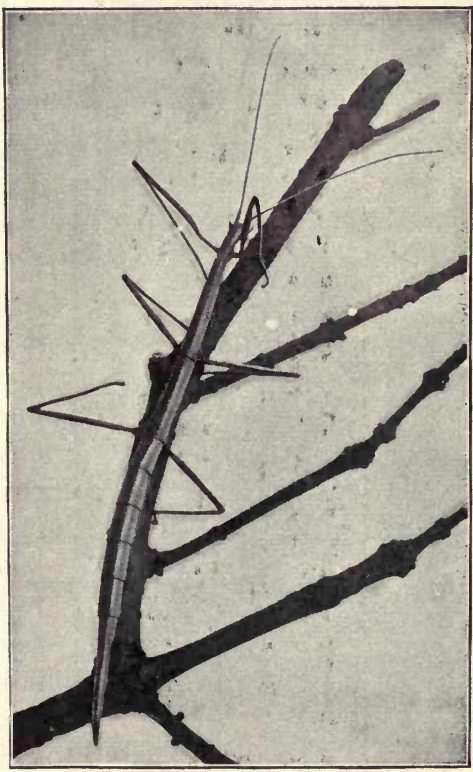

FiG. 12. - Walking stick (Diapheromera femorata). Photograph, natural size. clover, or almost any other kind of vegetation. There are numerous species of the cricket family (Gryllido). 
Walking Sticks. - The walking sticks (Phasmido) are so called because of their resemblance to a twig. Our common one (Diapheromera femorata) occasionally be-

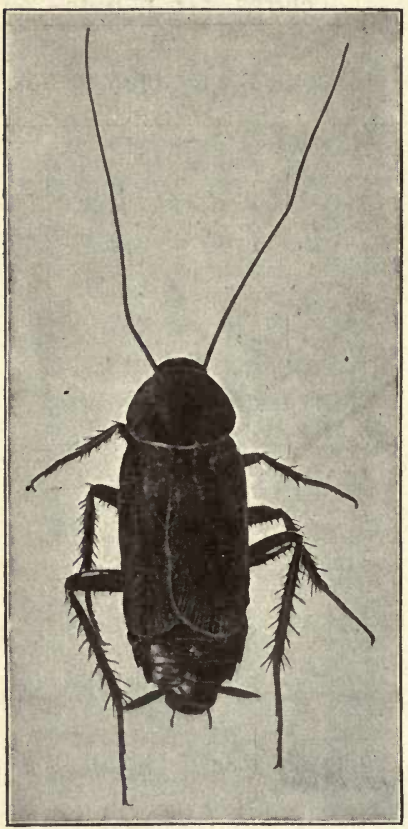
nearly twice natural size.
FIG. 13. - Large black roach. Photograph

comes so numerous as to strip all the foliage from acres of forests.

Cockroaches. - Of the four common species of roaches (Blattida) two are household pests imported from Europe. The large black roach (Periplaneta orientalis) frequents sugar refineries, slaughterhouses; and bake-shops. The Croton bug (Ectobia germanica) is common in kitchens. Roaches are omnivorous. They feed on clothing, bookbindings, breadstuffs, and living insects, such as bedbugs. Ships sometimes become so badly infested with roaches that the sailors wear gloves while sleeping to prevent the insects from gnawing their fingers. The eggs are inclosed in bean-shaped packets and may be seen hanging fast to the abdomen of the female or found in protected crevices. 


\section{DIPTERA}

This order includes all the true flies. They are the only insects except the male scale insects and a few May flies which have but two wings. About forty thousand species are known. Their study is of great importance because among them are some of our most deadly enemies, while others are our best friends.

\section{Mosquitoes}

The mosquitoes have a typical life history, and as they are in all parts of the world even as far north as Lapland and Greenland, the pupils will find no difficulty in securing specimens. Their habits may be studied from April to November by securing the eggs or larvæ and placing them in a jar of water with some algæ (frog spittle, etc.). These may be found in quiet pools of water not inhabited by fish. A rain barrel or a pail of water that has remained out of doors a few nights is apt to contain them.

Life History. - The eggs of the common species, Culex, are laid so that the two or three hundred stand on end and stick close together, forming a grayish floating mass nearly a quarter

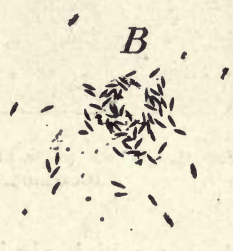
of an inch long. They are deposited early in the morning and often hatch within a day into minute wriggling larva which continue to grow from seven to 
fourteen days and attain a length of a half inch or more. If the eggs are laid in late fall they may not hatch until the next spring. The larva rises to the top of the water at intervals to breathe through a tube projecting from the tail end. This tube extends throughout the body and thereby supplies the tissues with oxygen.

After three molts the pupa stage is assumed and lasts from two to five days, depending upon the temperature,

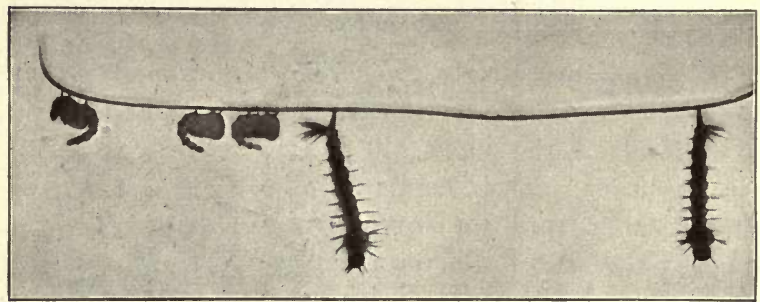

FrG. 15. - Three pupæ and two larvæ of mosquitoes at the surface of the water breathing. Photograph from life, twice natural size.

during which air is admitted to the body by two earlike organs on the thorax. In the next transformation the adult mosquito emerges from a slit in the back of the pupal skin and is ready in a few minutes to fly.

Food. - In its method of taking food the mosquito differs from the locust, as it has no biting apparatus but a piercing and sucking organ forming the proboscis. The labrum (upper lip) and labium (lower lip) form a tube inclosing the pair of hairlike mandibles and maxilla in addition to a tubular stylet, the hypopharynx, an outgrowth from the floor of the mouth. The hypopharynx lies against 
the labrum so as to form a canal through which the food passes (Fig. 18). These several partsmay be seen under the microscope by placing the head of a female in a drop of water on a glass slide and pressing lightly on the cover glass laid over it. The favorite food of the female is blood of any of the vertebrates. The male never bites and may be distinguished from the female by the antennæ which are much more richly feathered. The two chief genera of the four hundred species of mosquitoes are Culex and Anopheles. In the female of Culex, the palpi are not more than a fourth as long as the proboscis, while in Anopheles, the proboscis and palpi are almost equal. The palpi are quite long in the males of both genera. When at rest, the pro-

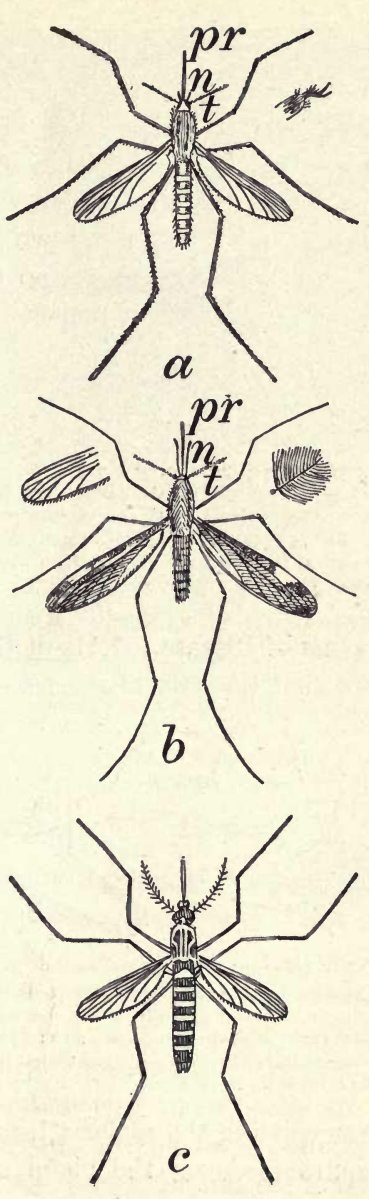




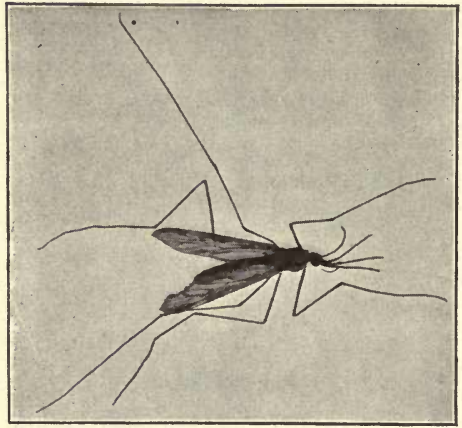

Fic. 17. - Photograph of Anopheles, the agent transmitting malaria. The antenno are curved and the upper two of the three straight projections from the head are the palpi. Enlarged three diameters. boscis, head, thorax, and abdomen of Anopheles are all in a straight line, and the body is held oblique to the surface to which the insect adheres, apparently trying to stand on its head. Members of the genus Culex have a bend at the juncture of the abdomen and thorax and hold the body parallel with the surface to which they cling. Agents of Disease. - About the year 1899 it was clearly shown that the several species of Anopheles are the agents

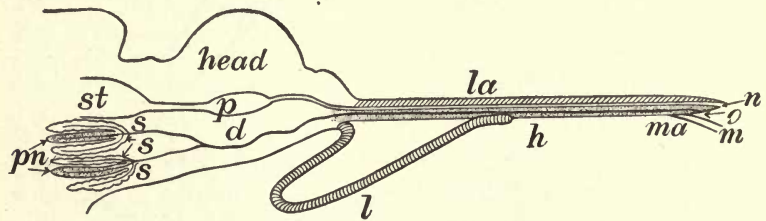

FIG. 18. - Diagrammatic vertical section of the head and proboscis of a mosquito.

$l$, labium bent as when the other parts pierce the skin; $p$. pumping organ; $o$, hypopharynx through which is a channel for the exit of the secretions of the poison and salivary glands $p n$ and $s ; d$, exit for poison and saliva; $m$, maxilla ; $m a$, mandible; $l a$, labrum below which is the channel conducting the food from the inlet at $n$; $s t$, stomach. Drawing by Reese.

in transmitting the malaria from man to man. When the mosquito feeds on the blood of a malaria patient thou- 
sands of the germs, Hamameba tertiana, are taken into its stomach, from which they migrate to the salivary glands (Fig. 18), and thence are forced with the saliva into persons bitten later. The saliva is ejected by the mosquito to break up the red blood cells which are too large to pass through its proboscis. The itching and painful effect of the bite are due to the poison injected along with

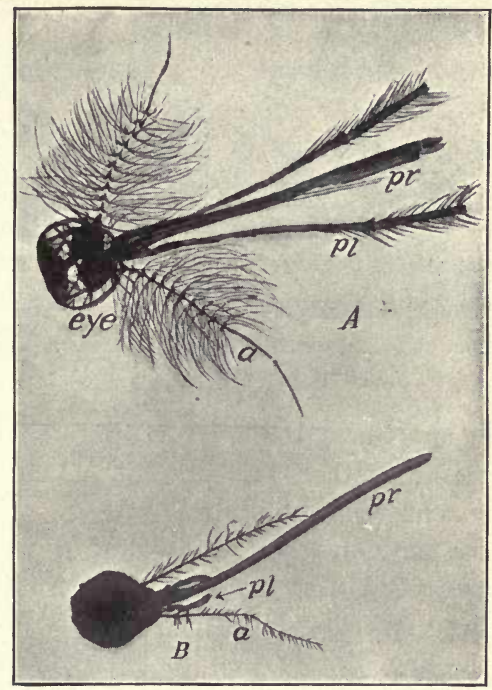

FIG. 19. - Photograph of heads of mosquitoes. $A$, male ; $B$, female; $a$, antenna ; $p l$, palpus ; $p r$, proboscis.

the saliva.

Lately it has been shown that yellow fever is transmitted by mosquitoes and in no other way. The only offender is Stegomyia fasciata. It is probable that these insects are responsible for some other diseases affecting man.

Destruction of Mosquitoes. - On account of the fact that the mosquitoes are responsible for more sickness and death annually than all the wars of the world, efforts are being made to exterminate them by draining the stagnant 


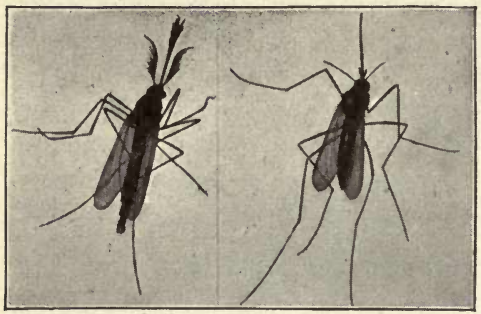

Fic. 20. - Culex, male and female. Photograph, three times natural size.

ponds and marshes.

Where draining is impossible the larvæ have been killed by pouring kerosene over the water, which prevents them from getting any air. A quart of the oil is sufficient for an area of five hundred square feet. It should be applied every two weeks during warm weather. Cuba spent a hundred thousand dollars in one year to control the mosquito pest, and as a result Havana was freed of yellow fever for the first time within a hundred years. Experiments conducted in my laboratory show that most ponds may be kept free of mosquitoes by introducing into them newts, blunt-nosed salamanders, fish, or dragonfly larvæ.

The crane flies resemble the mosquitoes, but

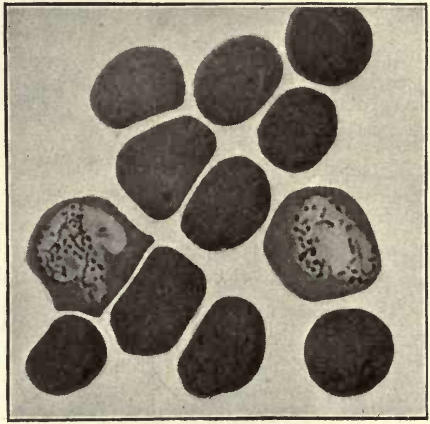

FiG. 21.-Blood corpuscles of a patient with malarial fever. Two corpuseles contain the parasites. Photograph, enlarged one thousand diameters.

most of them are much larger and they have no scales on the wings, the sure mark of a mosquito. The 


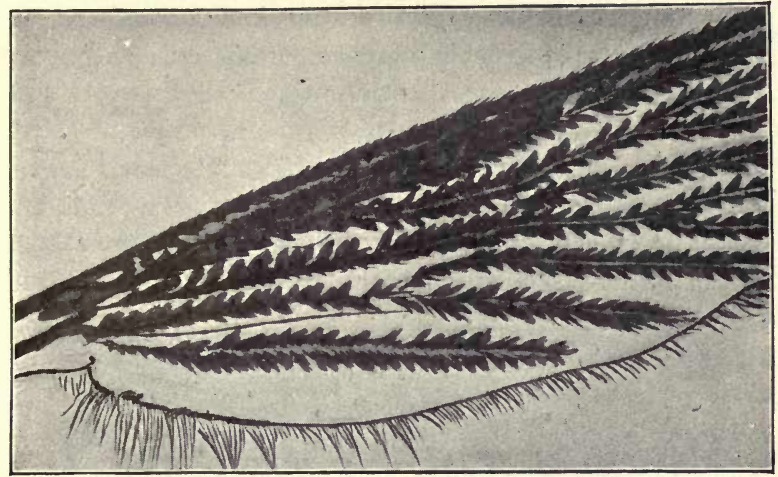

FIG. 22. - Wing of a mosquito. Photographed through the microscope to show the scales.

crane flies are easily recognized by their long brittle legs

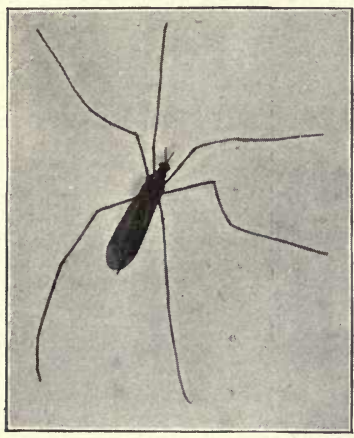

Fia. 23. - Cranefly. Photograph, natural size. and long neck. The larvæ of many species do some damage among the roots of grass.

\section{House Fly (Musca Domestica)}

This nuisance is found in most parts of the entire world. Recently it has been shown that its natural breeding place is in the manure thrown out of horse stables. The hundred or more eggs deposited at intervals by a female, hatch in from six to twelve hours into white pointed larvæ called maggots. These molt 
twice and attain full size in from four to eight days, whereupon the outer skin hardens, swells out, and turns brownish to form cases within which the pupr transform in from four to eight days into the adults.

If boards of health would compel the frequent removal of horse manure from the vicinity of towns the fly nuisance might be greatly abated. About one fifth of the soldiers in the national encampment in 1898 developed typhoid

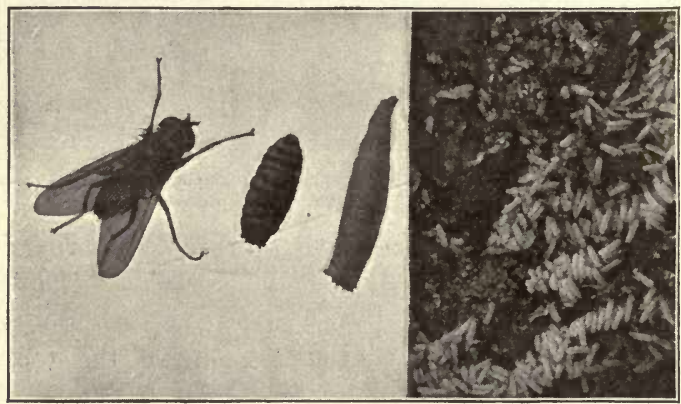

Fra. 24. - Common fly, its pupa, larva, and eggs. Photograph, twice natural size.

fever, which was undoubtedly transmitted in some cases by flies. These insects visit unclean places and thus carry the germs on their feet to distribute them later as they walk about over our food. I have found more than a hundred germs (bacteria) clinging to the feet of one fly.

The house fly never bites, but before a rain the stable fly (stomoxys), seen in large numbers on the cows, enters the house and frequently bites human beings. Other relatives of the house fly are the blowfly or blue-bottle 
fly, which lays its oval white eggs on decaying meat, where the larvæ (maggots) complete their growth in about ten days; the screw-worm fly, usually breeding in putrefying flesh, but sometimes in sores on animals and even human beings; and the cabbage fly, whose maggot lives in the roots of young cabbage and cauliflower in early summer, causing great loss to these crops.

\section{Other Important Flies}

Tachina Flies. - All of the numerous species of the Tachinas are beneficial, as their larvæ feed on the larvæ of harmful insects such as caterpillars and cutworms. The surest way to secure specimens is to look for the minute oval eggs glued to the skin of a caterpillar, which should be fed in a box containing an inch or two of earth. The little maggot emerging from the lower side of each egg

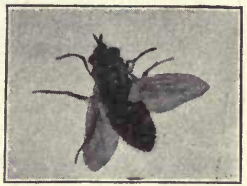

FIG. 25. - Photograph of a Tachina fly. Twice natural size. penetrates the host and feeds on its fatty matter a week

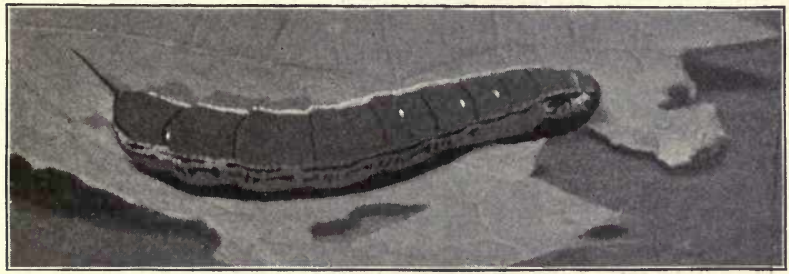

Fia. 26. - Photograph of four eggs of a Tachina on a larva of a Catalpa moth. Natural size.

or two, after which it comes forth and remains several days on or near the surface of the ground, a quiescent pupa 
within its hardened brown skin. In the mean time transformation to the adult fly occurs, and the skin is then ruptured for its exit.

Howard says he has seen millions of the army worm at work and not a single individual could be found which did not bear Tachina eggs. One great outbreak of the army worm in Alabama in 1881 was completely frustrated by

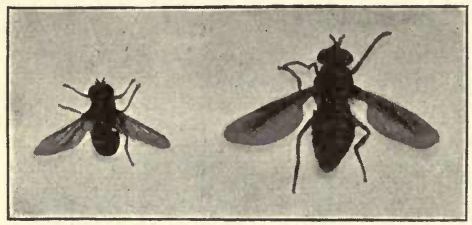

FrG. 27.-Syrphus flies. Photograph, natural size. the Tachina flies and a few other parasites.

Syrphus Flies. These are found among the flowers and shrubbery in the bright sunshine. They resemble the bees and the wasps, though many of them are as small as the house fly, and are often marked with orange or yellowish bands on the abdomen. The larvæ of some species may be found feeding on plant lice, while others live on decaying wood and manure. At least one, the drone fly (Eristalis tenax), breeds in decaying flesh, where its larva is known as the rat-tailed maggot. The idea prevalent, that carcasses of animals may generate swarms of bees, arose from the fact that the drone fly closely resembles the honey bee. The story of Samson in the Book of Judges relates such an incident.

Botflies. - The several species of these are parasites of vertebrates. The botfly of the horse (Gastrophilus equi) is familiar to all who have been about horses in late summer and noticed a large fly similar to a honey bee depositing minute yellowish elongate eggs on the fore legs of the horse. 
Later these are licked off by the animal and taken into the stomach, where they develop into grublike larvæ. After attaching themselves to the walls of the stomach, they are nourished by the blood and lymph of the host until the following spring, when they pass on through the canal, burrow into the ground, and transform into the adult about two weeks later. Bots are sometimes fatal to the
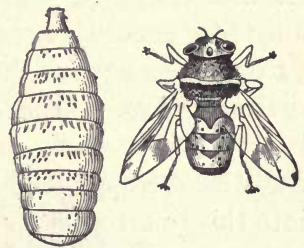
horse.

The ox warble or heel fly (Hypoderma lineata) is a pest to cattle raisers. The eggs deposited in the hair are licked off by the cow, and immediately hatching penetrate the esophagus to wander several months among
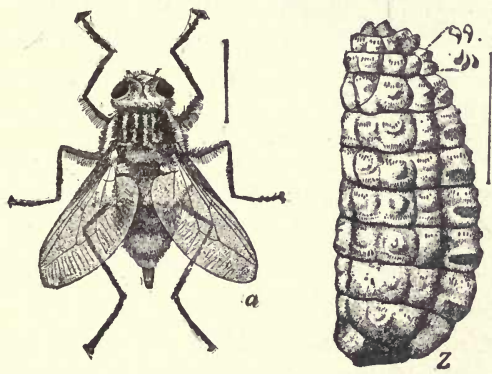

FIG. 29.-Ox warble or heel fly. $a$, adult; $i$, larva removed from beneath the skin of the cow. Natural size. From Insect Life. the tissues, finally reaching their destination beneath the skin on either side of the backbone. The lumps in these regions in spring and early summer reveal the presence of the insect. In late summer the maggot emerges, drops to the ground, and transforms to the adult. Stratton estimates that this parasite in the United Kingdom causes a loss of 
forty million dollars annually. The presence of these grubs in an animal produces holes in the hide and renders the meat along the back unwholesome. From January to June fifty per cent of the cattle received in the Union Stockyards at Chicago are thus affected.

Hessian Fly. - The Hessian fly (Cecidomyia destructor) is familiar to most agriculturists through its ravages on the wheat crop. It is supposed to have been introduced into this country on the straw brought over by the Hessian

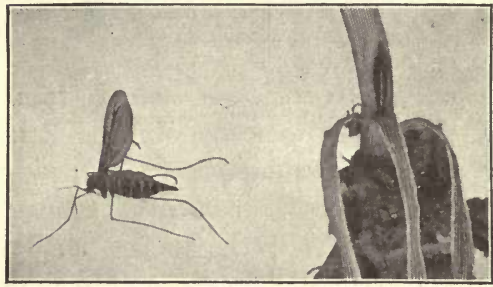

FIG. 30. - Photograph of the Hessian fly, twice natural size. The flaxseed or pupa is at the base of a stalk of wheat from which the leaves are stripped down. troops in the Revolutionary War. Specimens for study are easily secured by examining affected wheat fields in May, June, July, November, or December. There are two generations a year. The minute reddisheggs are laid in the spring on the upper surface of the leaves, where a fortnight later they hatch into wormlike larvæ. By June they attain a length of a fourth of an inch, and transform to the flaxseed or pupa between the leaves and the stem at its base. The stalks affected are in an inclined or brokendown condition. The adult fly emerges from the pupa case in August or September ready to oviposit on the fall crop wherein the pupæ remain during the winter. This insect annually damages the wheat crop to the extent of forty millions of dollars. 
Other pests closely related to the Hessian fly are the wheat midge, feeding upon the kernels of grain, the cloverseed midge, whose larvæ destroy the growing seed of the clover, and the pear midge, feeding in young pears.

Though the word "Diptera" signifies two wings, yet there are a few members of the order like the fleas which have lost their wings because of their parasitic habits. The sheep tick dwelling in the wool of the sheep, the louse parasite on the honey bee are also examples of wingless flies.

Nearly all of the Diptera have a com-

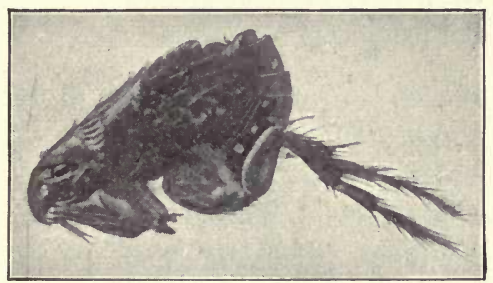

FIG. 31.-Common dog or cat flea (Pulex serraticeps). Photograph, enlarged thirty diameters.

plete metamorphosis, i.e., exhibit four stages in their life history. Most species deposit eggs, but a few, such as the flesh flies, bring forth their young alive. The larva in this order is an active wormlike creature which in some species, such as the mosquito, buffalo gnat, and horse flies, dwells in the water, while in others it lives in decaying matter or is parasitic in plants or animals. The larva sheds its skin (molts) two or more times, and usually the skin shed last forms a kind of case in which transformation to pupa and from pupa to adult occurs. The life of the adult insects of this order is seldom longer than a few weeks, but some species such as the house fly and certain mosquitoes live in a dormant state for several months during the cold season and become active in the spring. 


\section{HYMENOPTERA}

The members of this order are readily distinguished from other insects by the presence usually of four scaleless transparent wings of which the hinder pair is the smaller. The sting present at the end of the abdomen in the females of many species is a structure not possessed by the members of any other order.

\section{Honey Bee (Apis mellifica)}

Honey bees are social insects, dwelling in colonies composed of three kinds of individuals. The males perform no work and are therefore called drones. The imperfectly developed females are named workers, because they perform all the labor. The perfect females of which only one is allowed to remain in a hive are the queens. They do nothing but lay the eggs. A colony after taking possession of a hive or hollow tree forms out of wax secreted by the

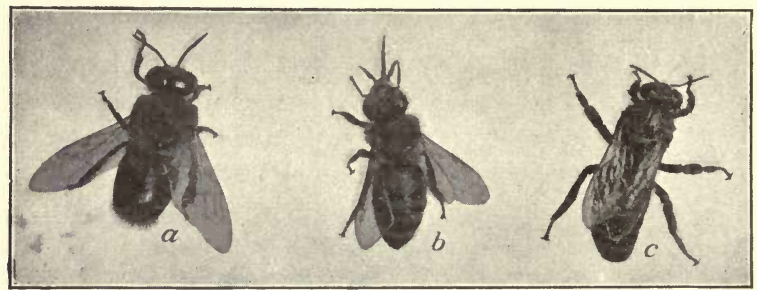

FIG. 32. - Photograph of honey bees natural size. $a$, drone; $b$, worker; $c$, queen.

workers a comb of many hexagonal cells. During the summer many of these cells are stored with honey for food 
in winter. This is not found in flowers, as is generally supposed, but is manufactured by the bees from nectar produced by glands in the flower. The nectar passes into the honey stomach where certain secretions act on it before it is regurgitated into the cells ef the comb.

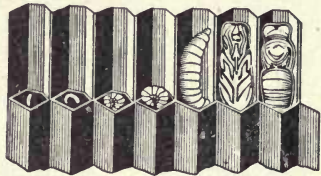

FIG. 33. - An egg, four larvæ, and two pupæ of the honey bee in their cells. Natural size.

The amount of work accomplished by a hive of bees

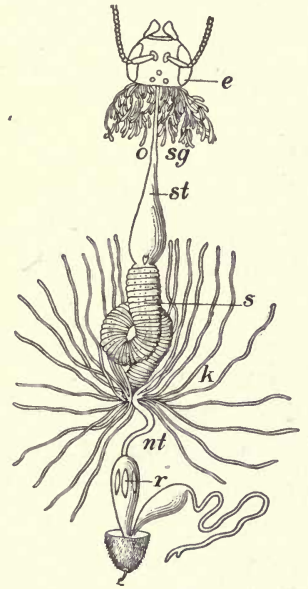

Fig. 34. - Alimentary canal of a honey bee. st, honey stomach; $s$, true stomach; $n t$, intestine; $o$, esophagus; $s g$, salivary glands; $k$, kidneys. Enlarged six diameters. is wonderful. A single swarm has been known to collect thirty-two pounds of material in a day and some swarms of the Cyprian breed have produced one thousand pounds of honey each in a season. The usual yield for a colony is less than a hundred pounds annually.

Some of the cells are used for breeding purposes. The queen seems able at will to lay eggs that will produce either drones or females. The eggs destined to become queens are laid in larger cells, and the larvæ, footless white grubs, are furnished a specially nutritious diet.

Honey bees are valuable not only for the honey and wax produced, but also as a means of cross-fertilizing flowers. 


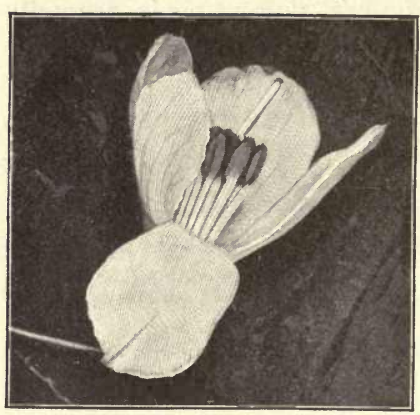

FIG. 35. - Flower with one petal turned down to show the single female organ, the pistil, projecting a quarter of an inch above the several male organs, the stamens.

Usually blossoms contain within the showy colored cup a central pinlike filament, the female organ, or pistil surrounded by several threadlike filaments with elongated heads giving off a fine powder, the male elements called pollen, which by coming in contact with the pistil causes it to produce seeds and fruit. Experiments have shown that when the bees transfer the pollen from one blossom to another more fruit and of much finer quality results than if the pistil is fertilized by the pollen of the same blossom.

\section{Bumble Bee (Bombus fervidus)}

The common bumble bee belongs to a group of social bees dwelling in communities of rather limited numbers. Early in the spring the queen, the only one of the colony living through the winter, constructs waxen ovoidal cells in an abandoned mouse's nest and lays eggs hatching into workers. These like the honey bees are imperfect females and much smaller than the queen who no longer collects food but attends to home duties consisting mostly of egg laying. In July some of the eggs are infertile and there- 


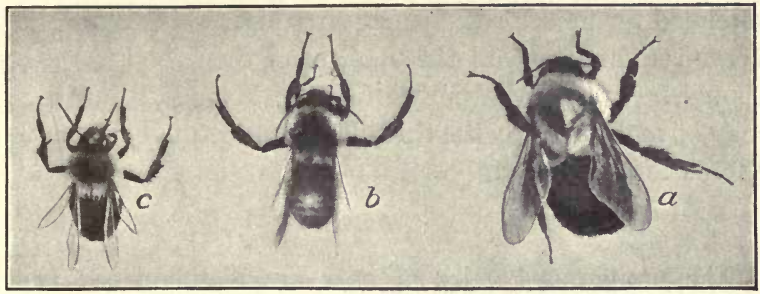

Fig. 36. - Photograph of bumble bees. $a$, queen; $b$, worker ; $c$, drone. Natural size.

fore hatch into males also called drones. These fertilize a few of the queens hatching late and at the beginning of winter die, as do also all the workers.

\section{Wasps}

Among the wasps are both social and solitary forms. The common bald-faced hornet (Vespa maculata), the yellow jacket (Vespa germanica), and the familiar paper

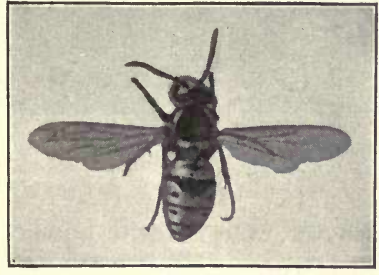

Fig. 37. - Yellow jacket. Photograph, natural size. wasp (Polistes) all have a life history similar to the bumble bee. The sand wasps and mud wasps are solitary forms of much the same habits. The latter construct mud cells side by side against the walls or ceilings of a building and after depositing an egg in each cell stored with several paralyzed spiders or other small insects seal it. The mother paralyzes the insects 
intended for food for her young by stinging them in a chief nerve center. To find the young and their food the nests should be examined in May or June. The adult mud wasp may be recognized by the threadlike connection between the thorax and abdomen.

\section{Ants}

The numerous species of ants are distinguished from the other members of the order by one or two swellings on the slender stem (petiole) connecting the thorax and abdomen. They dwell in communities in which there may be as many as five different castes or forms. In addition to the ordinary winged males and females, there are two kinds of workers, and the soldiers adapted for fighting.

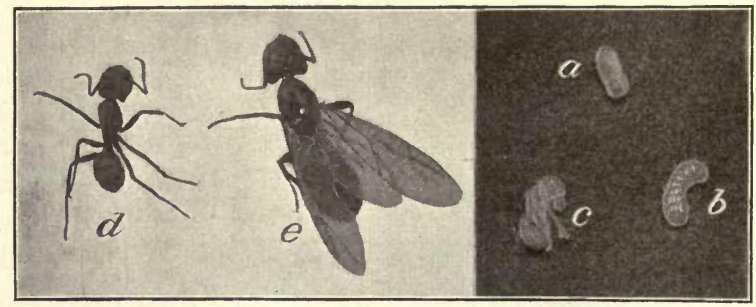

FTG. 38. - Photograph of ants. $a$, cocoon containing a larva ; $b$, larva ; $c$, pupa ; $d$, adult worker; $e$, queen. About natural size.

The workers as with the bees are undeveloped females which never possess wings. The true females or queens have wings in the early part of the year until after the nuptial flight, at the end of which they tear them off and seek places to lay their eggs beneath stones, in decaying wood, or under the bark of trees. 
Ant nests are easily found in decaying logs and under stones and boards during the summer and autumn months containing eggs, larvæ, pupæ, workers, and queens. The eggs are white, just visible to the naked eye, and the larvæ may be distinguished from the pupæ sometimes encased in cocoons, by the absence of legs.

The favorite food of some ants is the honey dew excreted by plant lice from the alimentary canal. Most ants are fond of any kind of sweets and sometimes cause much annoyance in houses. They are easily got rid of by sprink-

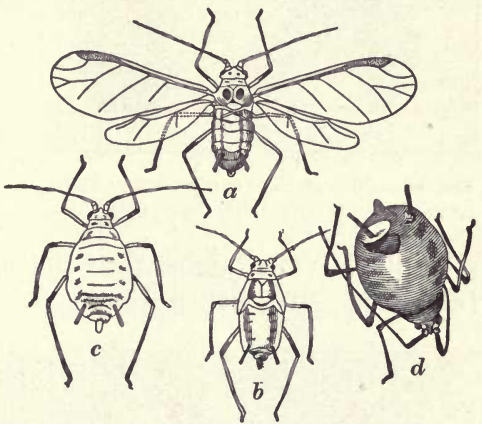

Frg. 39. - Wheat plant louse enlarged about five times. $a$, winged female; $d$, wingless female with a hole from which a parasite escaped; $b$, young louse. After Riley.

ling places frequented by them with a mixture of four parts pulverized sugar and one part arsenic. More than two thousand species of ants have been described. A half dozen different species may be found in almost any locality.

\section{Sawflies}

The sawflies are so named because of the structure of the ovipositor which contains two saws capable of being moved up and down to make apertures in vegetable tissue to receive the eggs. The habits of these insects which are 


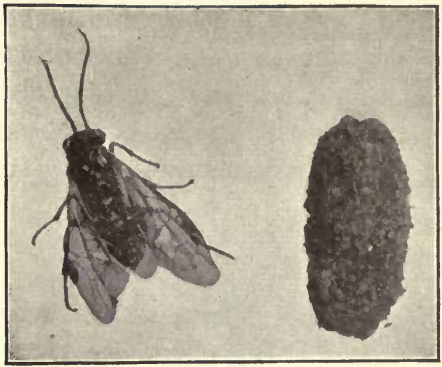

Fic. 40. - Photograph of currant sawfly, and cocoon dug from the ground. Twice natural size.

not true flies are easily learned from observing the common currant worm (Nematus ribesii). The minute elongate eggs are deposited on the under sides of the currant. leaves and gooseberry leaves in May and June where they hatch into yellowish green caterpillarlike larvæ attaining their full size of an inch in about two weeks. They then drop to the ground, and just be-

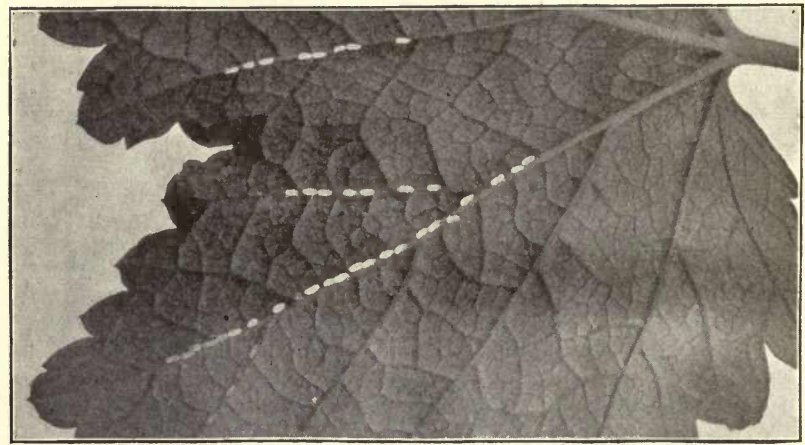

Fit. 41. - Photograph of a leaf of currant with eggs of the sawfly in their charac teristic location along the veins. Twice natural size.

neath the surface form cocoons from particles of earth within which they transform to pupæ and a few days later 
to the adult form. Of the two generations in the year, the one going into the cocoon state later remains therein over winter. The easiest way to study the life of this insect is to place in a box an inch layer of quite moist soil and several larvæ, which must be fed twice daily for about a week until they disappear in the dirt. At intervals of three days different cocoons should be opened to note the progress of the transformation from the larvæ to the adult state, occupying about a fortnight.

The sawflies numbering two thousand species cause an immense amount of damage. One kind defoliates the larch, another the elm, while the common rose slug, the larva of a small sawfly, causes havoc to the rose bushes. The slimy dark-olive pear slug, common on

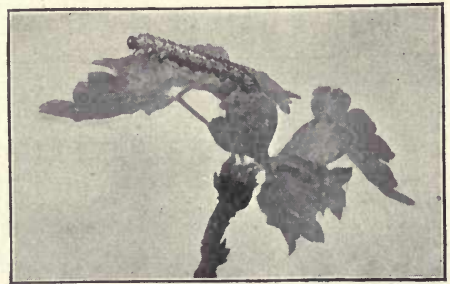

FIG. 42. - Photograph of the currant worm. Natural size. the under side of the

pear, cherry, and plum leaves in early summer, winters in a cocoon under ground and transforms to a sawfly the following spring. All the larvæ are easily destroyed by dusting the plants with hellebore.

\section{Gallflies}

The gallflies, more properly called wasps, as they have four wings, are minute insects about a quarter inch long with many-jointed antennæ and a chunky abdomen. They derive their name from the fact that most of the 


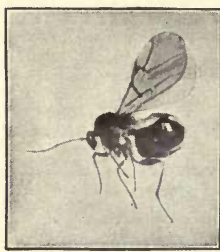

FrG. 43. - Photograph of oak gallfly enlarged twice.

fifteen hundred species lay their eggs in some part of a plant, and the developing larvæ by their excretions cause an overgrowth of tissue producing an enlargement called a gall. The oaks are most frequently affected. Each species forms its characteristic gall and always on the same kind of plant. A gall opened in May or June will usually contain a single wormlike white larva. The flies may be secured from many of the galls by tying a piece of cheesecloth over them in early June

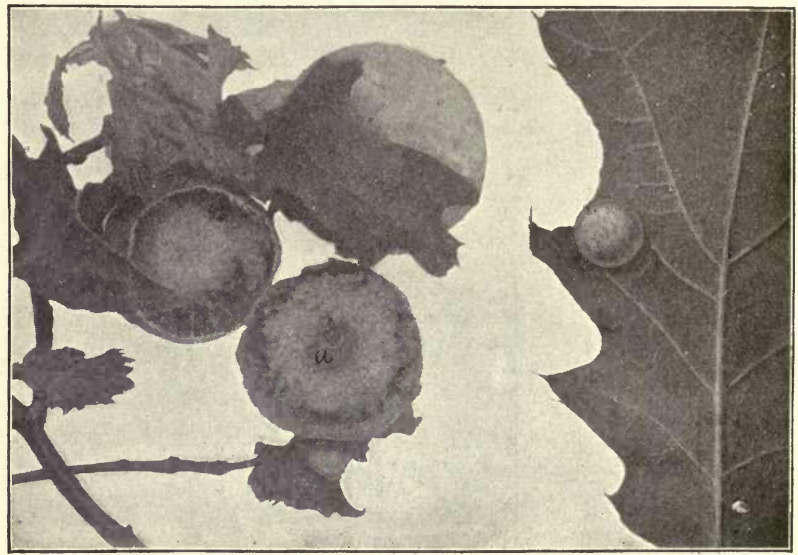

FiG. 44.- On the left three galls or oak apples, of which two are cut open. $a$, larva. On the right an oak gall about one month old. Photograph by Overton.

or by merely collecting them about the middle of June and placing in a tight box until the flies appear. Some- 
times, instead of the expected gall insects, a number of very minute Chalcis flies appear. These in their larval stage are parasites on the gallflies (Fig. 59).

Galls used in the making of ink and tannic acid are produced by a species of Cynips on the oaks of Asia and Europe. A few of the Diptera, many of the Hemiptera, and some of the Arachnida also produce galls. The maple spot gall, so common on the leaves of the red maple, is made by the fungus-gnat (Sciara) of the order Diptera. The conical gall of the witch-hazel is produced by a plant louse, as is also the cockscomb gall on the elm leaves.

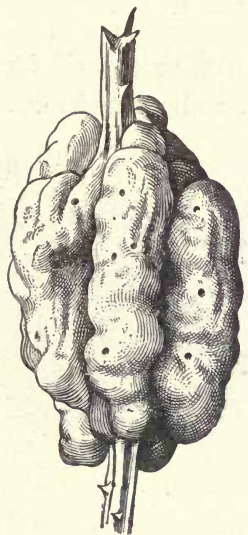

Fig. 45. - Blackberry knot gall common on the stems of the blackberry. Natural size.

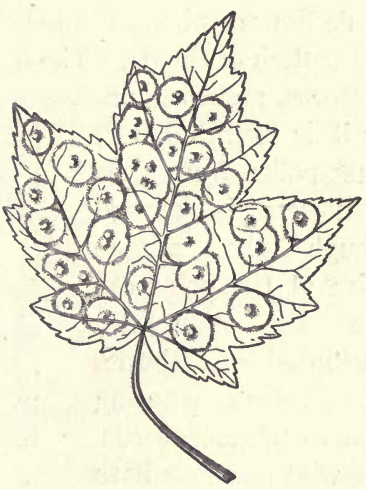

FiG. 46. - Maple spot gall produced by a fly.

Fig Producers. - The fig insect (Blastophaga grossomum) is the most valuable member of the gall family, as with- 
out its presence it is impossible to produce a first-class fig at a reasonable price. Cnly since the year 1900 has the secret of growing high-grade figs been utilized in this country. The Smyrna fig cultivated in California bears only
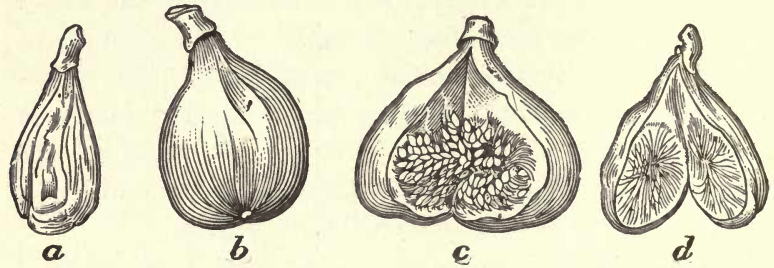

FIG. 47. - Figs. $a$ and $d$, unfertilized; $b$ and $c$, fertilized. After Howard.

female flowers within the hollow globular receptacle forming the flesh of the fig. The fig will lack the desired flavor, sweetness, and size unless it is fertilized, i.e., unless pollen from male fig flowers is carried through the minute orifice at the point opposite the stem and distributed over the female flowers, causing them to produce seeds. The wild figs have both kinds of flowers, and when these are planted

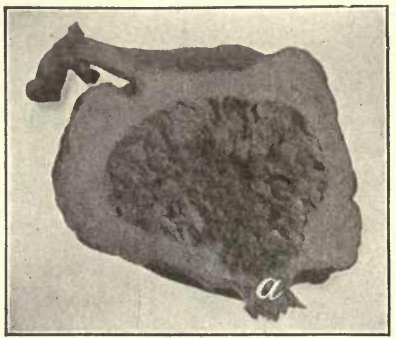

FIG. 48.- Photograph of the cut surface of a wild fig showing over twenty galls: $a$, place where the insect enters the young fig to lay eggs.

\section{near the Smyrna fig} trees the fig insects emerging from the galls surrounded by male flowers carry with them some pollen on the wings 
and legs as they pass out. At once they enter another fig to deposit eggs. If this is a Smyrna fig, its female flowers will be dusted with pollen from the insect and

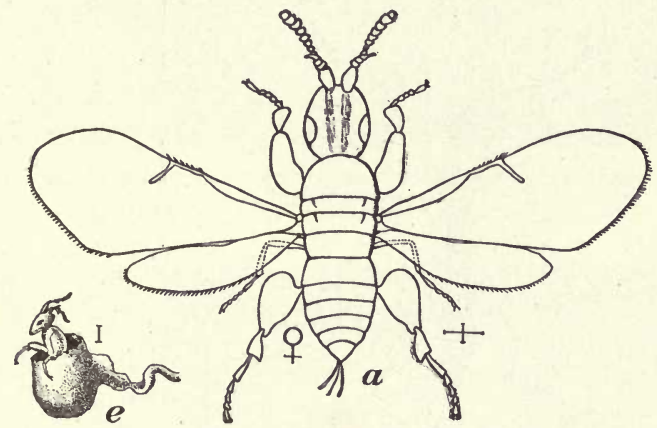

Fig. 49 - Fig insects; $a$, female ; $e$, emerging from a gall, many of which are seen in Fig. 48. Lines at right show natural size. After Howard.

thereby fertilized. The insect will not lay eggs in the Smyrna fig, but only in the wild fig; therefore one individual may carry the pollen to a dozen Smyrna figs before finding a wild fig whose character it does not recognize before entering within the receptacle.

\section{Ichneumon Flies}

The ichneumons are incorrectly called flies, as they have four wings. They go a step further in parasitism than the preceding group, as they are parasitic on or within other insects and usually while the latter are in the larval or pupal stage. There are over five thousand species varying in size from an eighth of an inch to one and a half 
inches in length. They may be recognized by the division of the under side of the last segment of the abdomen, the attachment of the ovipositor before the tip of the abdomen, and usually the heavy marginal vein of the front

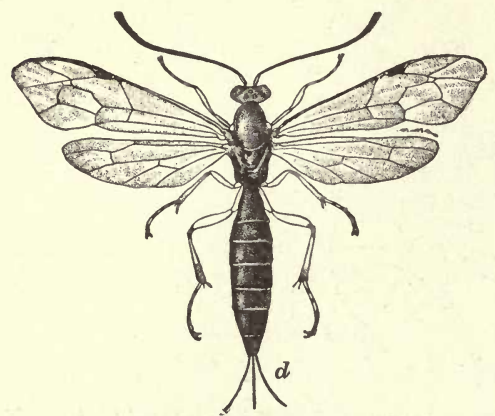

FıG. 50. - Pimpla inquisitor, an ichneumon, enlarged about three times.

wings with a dark spot near its middle. Pimpla inquisitor is a widespread parasite of the tent caterpillar, army worm, tussock moth, and fall webworm. It deposits from five to ten eggs beneath the skin of its victim, within which the larvæ feed a few days until they attain adult size. They then emerge and spin their cocoons in a bunch wherein transformation to the adult occurs.

In the autumn of 1901 fall webworms were so numerous in Eastern Pennsylvania that scarcely a tree was to be found that did not harbor from a dozen to a hundred. They crawled over the sidewalks and crept up the houses. In late autumn they formed cocoons of which I collected a large number, and in over ninety per cent of them the insect had been devoured by the larvæ of the Pimpla. As a result, the webworms instead of being numerous the following season were very few.

A small ichneumon often attacks the large green tomato 


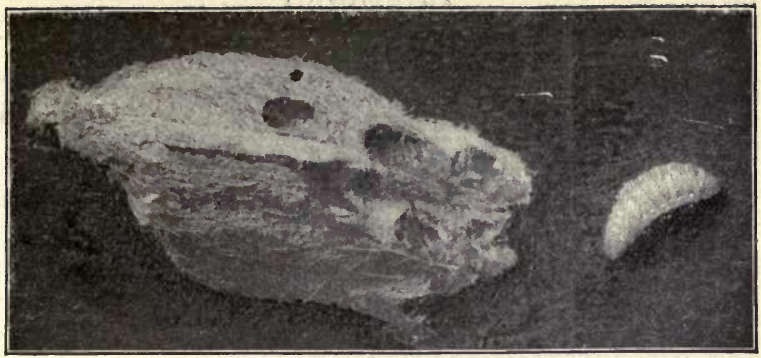

Fig. 51. - Bunch of Pimpla cocoons removed from the cocoon of the fall webworm, and the larval parasite.

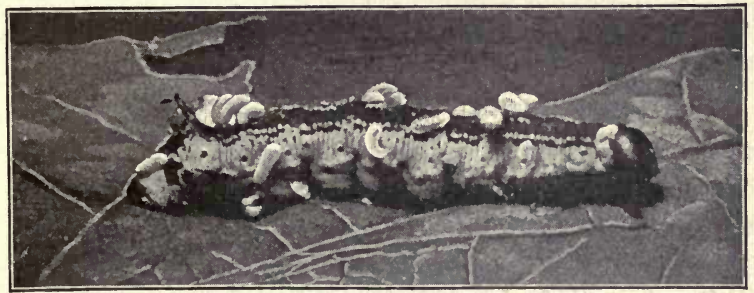

FIG. 52. - Photograph of ichneumon larvæ issuing from the Catalpa eaterpillar. Natural size.

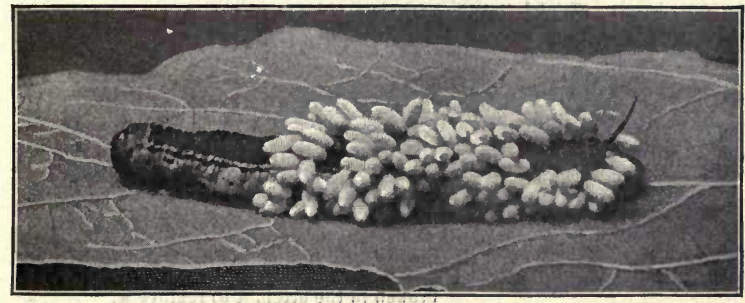

FIG. 53. - Photograph three hours later of the same caterpillar as shown in Fig. 52. Slightly enlarged. 


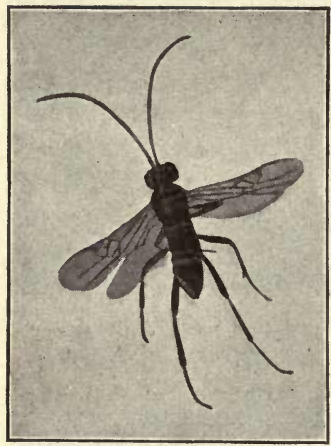

Fig. 54. - One of the many adult insects that came from the cocoons shown in Fig. 53. Enlarged six times.

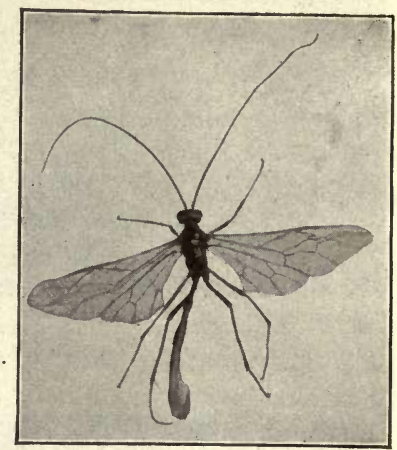

FrG. 55. - Photograph of Ophion. Natural size.

worm upon which its cocoons may be seen in late summer or autumn. A similar species is parasitic in the larva of the hawk moth feeding on the leaves of the Catalpa tree in September. Ophion and Trogon are two of the large forms often issuing from the cocoons of the swallowtail butterflies. Thalessa is distinguished by its long ovipositor used

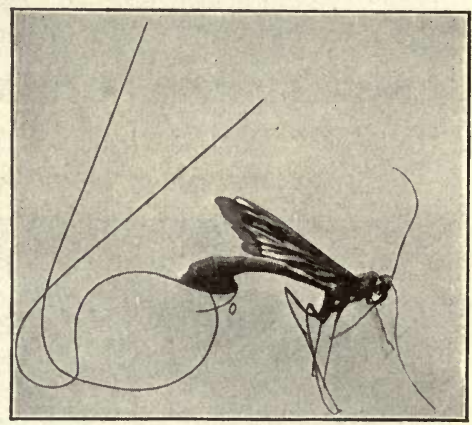

FiG. 56.-Photograph of Thalessa; $o$, the ovipositor equal in length with the two supports was inserted two inches in an ash tree, and was broken in the attempt to remove it. in depositing eggs an inch or two within a tree where 
the larvæ may feed on wood-boring larvæ. . Ichneumon flies render great service to agriculture by keeping in check the harmful caterpillars.

\section{Chalcis Flies}

The chalcids have habits similar to the ichneumons from which they may be distinguished by the outward bend of the antennæ and the almost

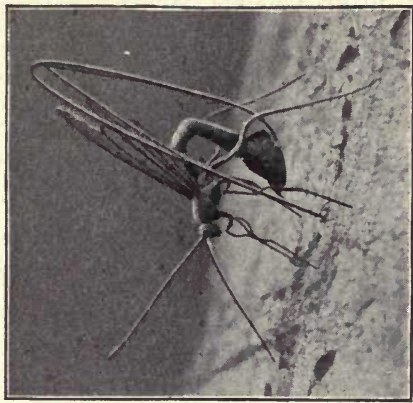

FIG. 57. - Thalessa boring in an ash tree to deposit its eggs in the burrow of a horn-tail larva, a wood borer. Photograph, natural size. entire absence of veins in the fore wings. They are all small, being from an eighth of an inch to a fourth of an inch long. Large numbers of

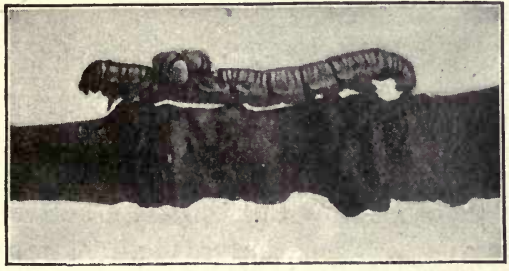

Fig. 58. - A bunch of five chalcid larvæ on the canker worm. Photograph, twice natural size. them may be secured by collecting a dozen or two cabbage worms (Fig. 67) in autumn and feeding them daily with fresh cabbage leaves. Within a week chalcid larvæ will be seen to issue from several and spin cocoons immediately in which they may remain all winter or if early in the season transform to pupæ and adults in about two weeks. Three out of every ten oak galls in late summer 
contain Chalcis larvæ which have devoured the gallfy larva. Some chalcids lay their eggs on the skin of the

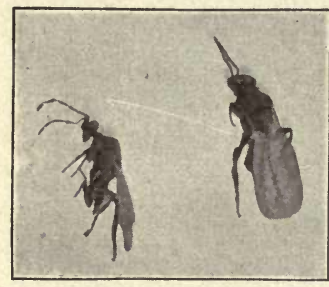

Fig. 59. - Chaleids transformed from the larvæ shown in Fig. 58. Photographed nine days after Fig. 58. Enlarged eight times. host as in the case of Euplectrus (Fig. 58), while others insert the eggs within the tissues and the larvæ do not appear on the surface until they are ready to spin their cocoons.

That the chalcids are most effective helps to man may be seen from the fact that in one year in the cotton fields of Florida ninety-five per cent of the eggs from which would have hatched the destructive cotton caterpillar were killed by a species of Chalcis.

\section{LEPIDOPTERA}

This order includes the butterflies and moths, which are readily distinguished from other insects by the presence of two pairs of wings covered with scales. In a few species the female has no wings. Butterflies usually fly by day and moths by night. When resting the wings of a butterfly are held vertical over its back, but a moth at rest holds its wings expanded or lying flat on its back. The antennæ of a butterfly are clubbed or enlarged at the end, while those of a moth taper and are often feathered throughout. The larvæ of butterflies never construct cocoons, while those of most moths spin or weave cocoons for the pupal stage. 


\section{Butterflies}

The seven hundred species of butterflies in North America, distributed from Central America to the Arctic Circle, are chiefly of value to man through the pleasure and profit they afford lovers of nature. Two or three species are decidedly harmful in the larval form. The two groups most abundantly represented in the temperate zone are the brush-footed tribe and the swallowtails.

Brush-footed Butterflies. - This group, whose members have imperfect fore legs, includes a number of common

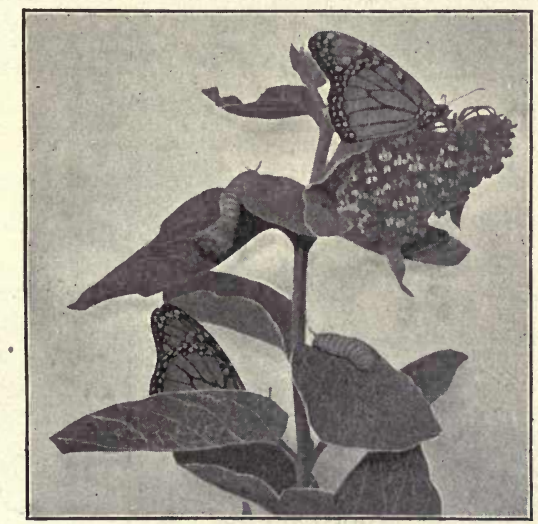

FiG. 60.-Phutograph of two larvæ and two adults of the Monarch butterfly. One third natural size.

large forms. The milkweed butterfly or monarch (Anosia plexippus) is quite as conspicuous as its black, white, and yellow-banded larva and bright green gold-spotted chrysalis 


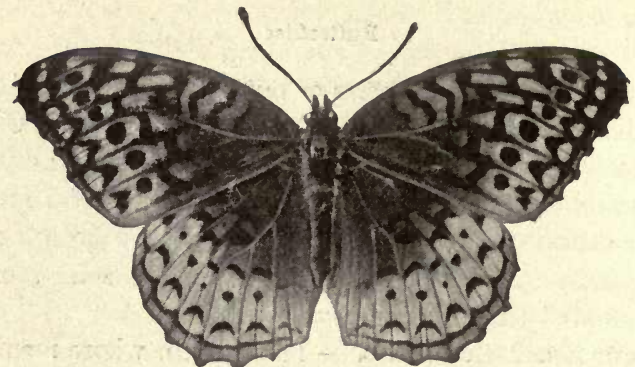

FIG. 61. - Silver-spotted fritillary. Photograph, natural size.

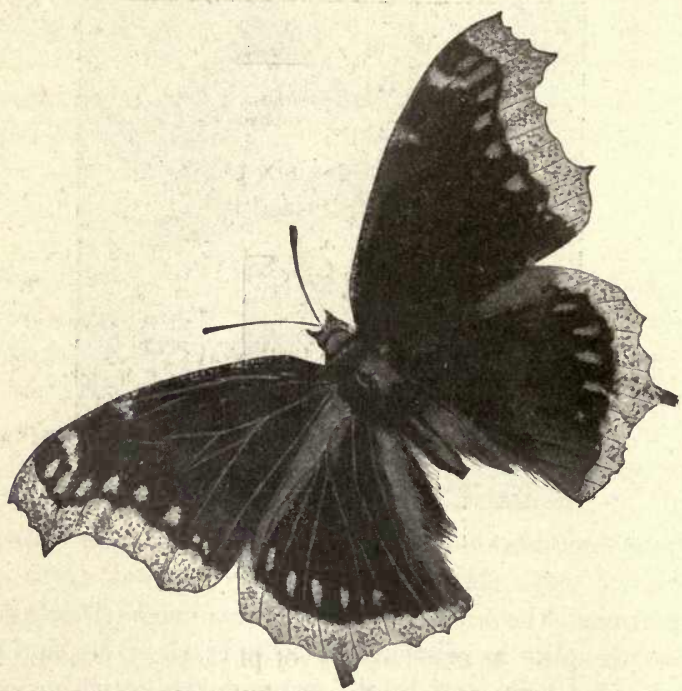

FrG. 62. - The mourning cloak. Photograph, natural size. 
found on the milkweed from June till Septenber. The Silver-spotted fritillary (Argynis), whose larva feeds on violets, and the mourning cloak (Vanessa antiopa), whose larva feeds on willows and poplars, are easily secured for study. The mourning cloak is the only kind of butterfly frequently seen in February and March.

Swallowtails. - The swallowtails and their allies making

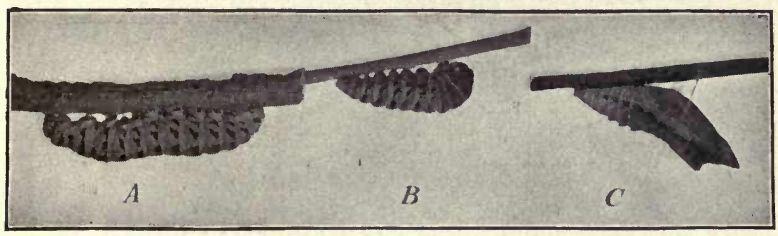

FiG. 63 - Common swallowtail, Papilio asterias; $A$, larva; $B$, preparing to enter on the pupal state; $C$, pupa as photographed twenty-four hours after.

up the family Papilionidæ have six perfect feet, and most of the swallowtails are characterized by a projection at the

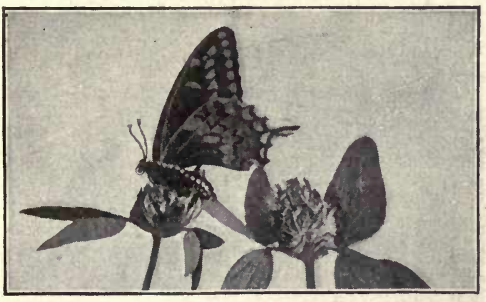

FiG. 64. - Photograph of the common swallowtail, Papilio asterias. One half natural size. posterior angle of each hind wing. They pass the winter in the chrysalid or pupal state, being always fastened by a girdle near the middle. The larvæ are naked caterpillars, usually of a green color, and feed upon a variety of plants. A most widely distributed form is the cabbage butterfly (Pieris rapa), 


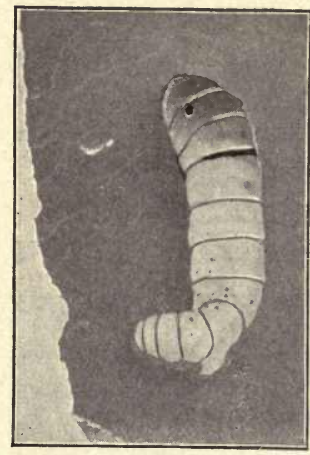

Fra. 65. - Photograph of the larva of a tiger swallowtail. Natural size.

whose life history may be studied to the best advantage in late summer and autumn. The species was brought from England to Quebec about 1860 in imported cabbages. In three years it had spread over an area of sixty miles in diameter. By 1871 it was present throughout eastern Canada and New England. Ten years later it was common from Hudson Bay to Texas, and since 1895 it has been a pest from the Pacific to the Atlantic.

The green larvæ are found from June to November by noting on the cabbage plants the dark shotlike excretions indicating the presence of the animals. Several placed in a box and fed daily with fresh cabbage leaves will within a week or two form cases of the last molted skins and change to the pupal

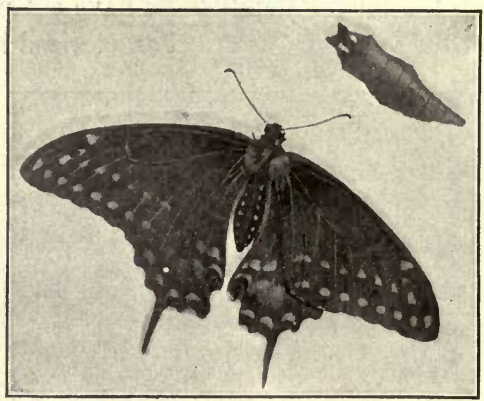

Fra. 66. - Photograph of pupal or ehrysalid case and the black swallowtail that came from it. Two thirds natural size. state, lasting in early summer but a few days, while later 
it may continue through the winter. Some of the larvæ collected will be found to be infested with chalcid parasites which issuing through the skin of the host will spin numerous small oval cocoons thereon. A larva thus affected dies.

Moths

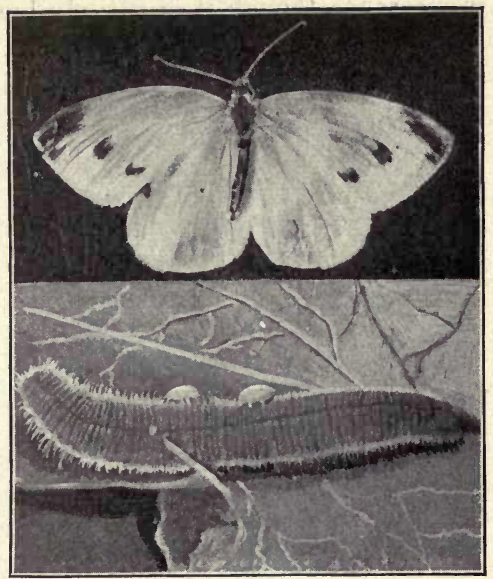

The species of the moths are more FIG. 67. - Photograph of cabbage butterfly and larva, the latter enlarged twice. numerous than the butterflies, and some of them are great pests in the larval form, though harmless in the imago (adult) state. A brief description of one or more species of the nine most important groups will give a clear idea of the relation of these insects to man.

Hawk Moths (Sphingidæ). - The sphinxes are the narrow-winged moths that visit the flowers at dusk and by some are supposed to be liumming birds. The tongue is in some species four or five inches long, but is kept closely coiled except when probing the flowers for nectar. The larva is characterized by a horn on the top of the last segment, or in its place a glossy eye spot, giving it a formidable 
appearance though it is entirely harmless. It enters the - ground to pupate without spinning a cocoon. The cater-

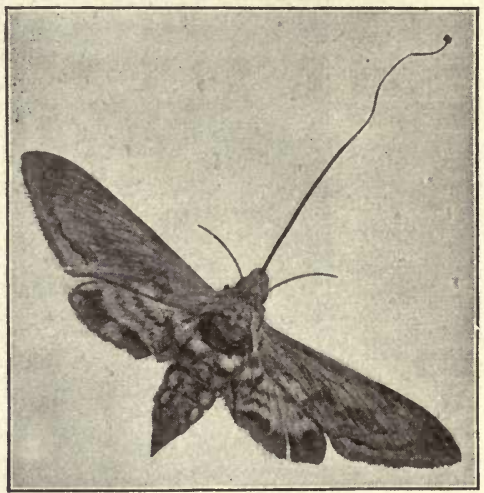

FIG. 68. - Photograph of the tomato-worm moth with its tongue uncoiled. One half natural size.

pillar defoliating the Catalpa trees in September, the large green tomato worm, and the tobacco worm often injuring the tobacco crop, are larvæ of sphinx moths.

Spinners (Bombycidæ). - This group is so named because the larvæ spin cocoons in which to pupate. They are distinguished from the

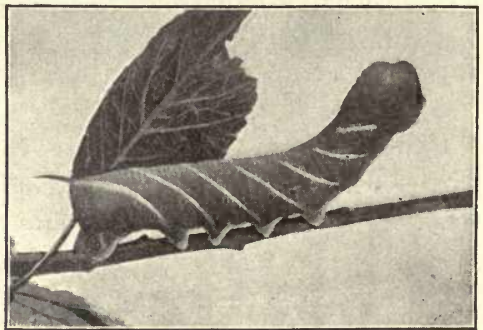

FIG. 69. - Photograph of tomato worm, the larva of the moth shown in Fig. 68. Two thirds natural size. 
hawk moths by their hairy bodies, and pectinated or feathered antennæ. The larvæ of the large forms are

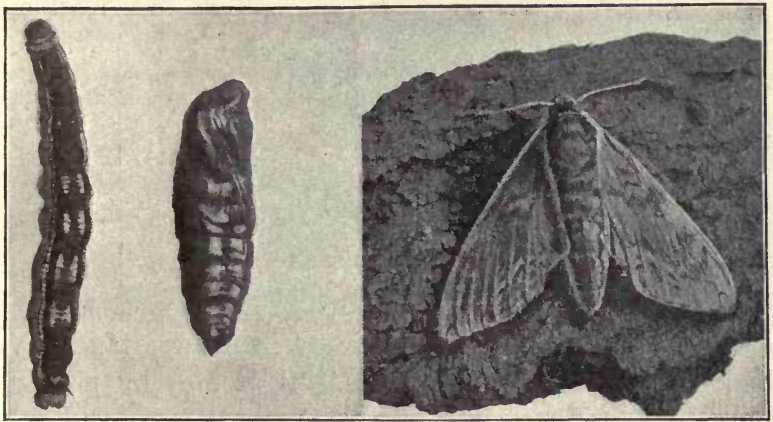

FiG. 70. - Photograph of the larva, pupa, and imago of the Catalpa sphinx (Ceratomia). Natural size.

called giant silkworms. Polyphemus is the American silkworm.

The silk of commerce is produced by the domesticated silkworm of China (Sericaria mori). In parts of China the moths live in a wild state, but in several portions of the

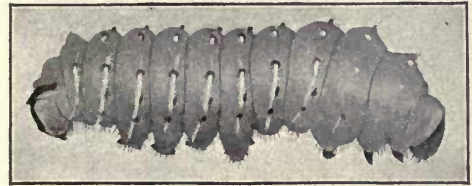

FIG. 71. - Photograph of a larva of polyphemus (Telea polyphemus). Two thirds natural size.
Old World the insect has been domesticated. The entire life history of the moth may be observed by any school able to secure mulberry or osage orange leaves. If neither of these trees grows in the locality, two or three white mulberry trees should be set 
out or seeds planted. The eggs of the silkworm moth may be procured of T. Keleher, 662 Massachusetts Ave. N. E., Washington,

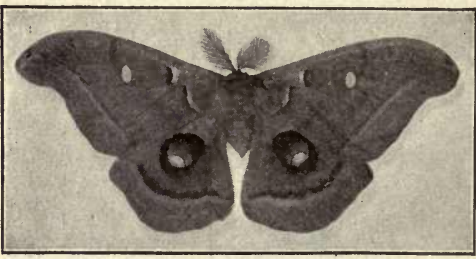

FIG. 72.-Photograph of Polyphemus. One half natural size.

D.C.; Dr. W. H. Hill, Peoria, Ill.; and Mrs. Carrie Williams, 1245 Logan Ave., San Diego, Cal. If kept cool they will not hatch until late in summer, but they may be made to hatch during April or May by placing them in a warm room a week. As soon as the minute hairy black larvæ break from the eggs they should be given very small tender leaves or larger leaves cut into small pieces. If fed several times daily with mulberry or osage orange leaves for a month, the larva will spin a cocoon with the secretion of the silk glands opening just beneath the mouth. The spin-

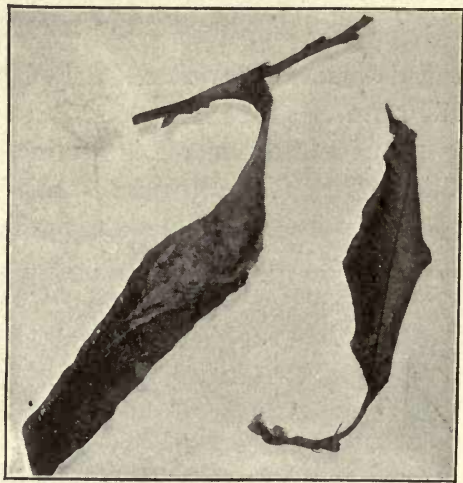

Fig. 73. - Photograph of cocoons of promethea moth.

ning occupies three days or more, and soon after its com- 
pletion the larva changes to a pupa which in a week or two is transformed to a white moth living only a few days

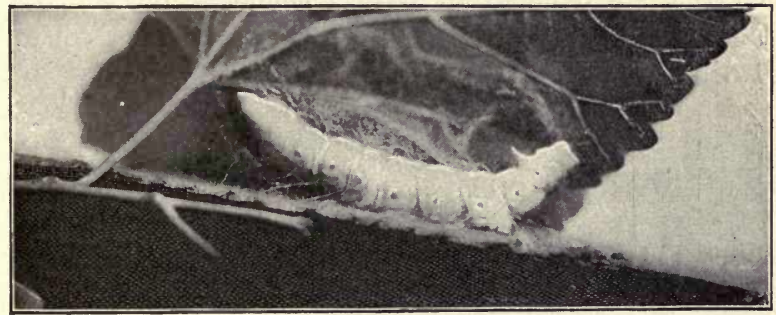

FrG. 74. - Chinese silk worm spinning its cocoon of silk. Photograph, two thirds natural size.

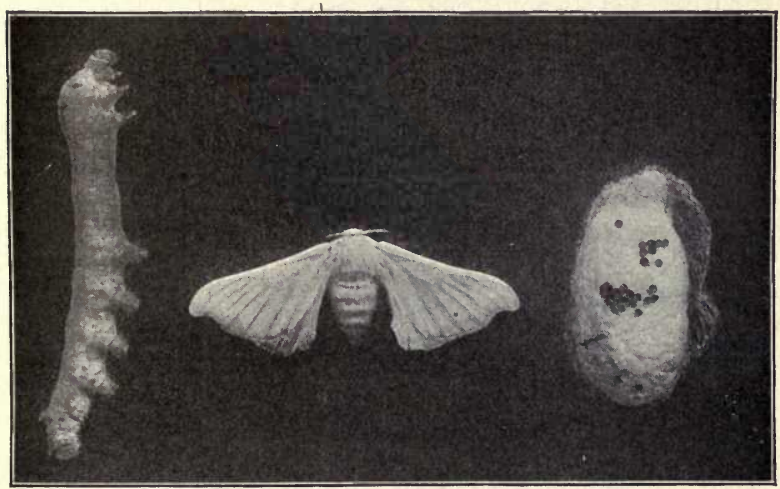

F1G. 75. - Four stages of the Chinese silk worm. The moth has emerged from the cocoon and laid some eggs on it. Photograph, natural size.

after emerging from its silken house. If the cocoons are wanted for silk, a day or two after their completion they are baked or steamed to kill the pupa. The thread form- 
ing the cocoon is then wound off on a reel, and is often found to be more than a mile long. Three thousand cocoons are required to make a pound of raw silk, and about ninety of the cocoon fibers as spun by the worm are twisted together to make a thread of sewing silk.

The value of the silkworm was dis-

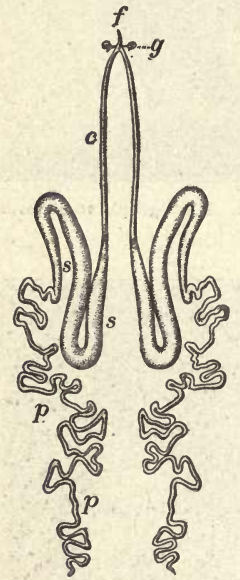

Fra. 76. - Silk glands of the silk worm. Natural size. covered 1700 B.c. by the wife of the third emperor of China, who is known as the goddess of silkworms. For nearly two thousand years, the Chinese kept the method of obtaining silk a profound secret. The penalty for carrying the eggs out of China was death. In 555 A.D., two Nestorian monks were bribed by the Byzantine emperor Justinian to bring him silkworm eggs concealed in the hollow of their pilgrim staves. The industry then spread rapidly throughout Europe, and in 1622 reached America, but owing to the high price of labor, the insect is not cultivated here to any great extent. From twenty-five thousand to fifty thousand cocoons are required to produce sufficient silk for a dress.

The forest tent caterpillar (Clisiocampa disstria) and its cousin, the apple tree tent caterpillar, are the only larvæ which spin webs in the trees in the spring. The larvæ break from the egg mass surrounding a twig, in early May, and in a few days construct a tent to protect themselves during the cold rainy weather. They grow to full size in 
about a month, when they crawl to secluded places and spin yellow cocoons from which the moths emerge two weeks later and deposit four or five hundred eggs for the following season. The Baltimore oriole is their greatest enemy.

The fall webworm (Hyphantria textor) is the larva spinning dense webs in the trees from July to September. It passes the winter as a pupa in its hairy cocoon attached to a limb or a leaf. The white moth comes forth the following summer. If these pests are numerous one year they are quite sure to be scarce the next, as the ichneumon flies prey on them extensively; otherwise they would ruin the autumn foliage of

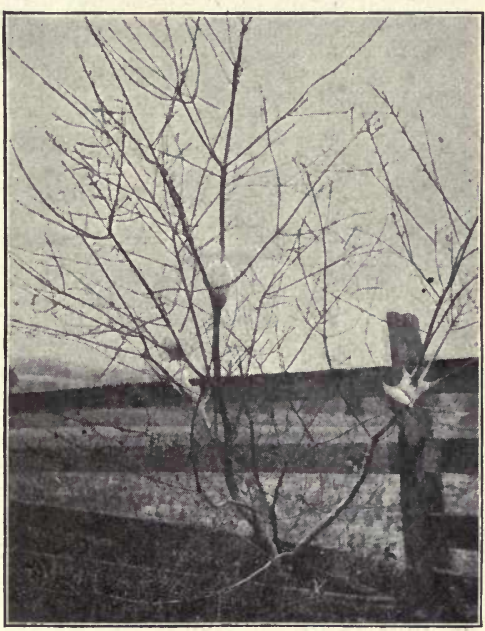

FIG. 77. - Three tents of the tent caterpillar in a tree which it has entirely ctripped of leaves. the trees.

Tussock moths of several kinds consume the leaves of the shade trees, but the "white-spotted" one (Notolophus leucostigma) is the commonest. The hairy tufted redheaded larvæ are found on the trees in June and July, and also in September and October. There are two generations, 


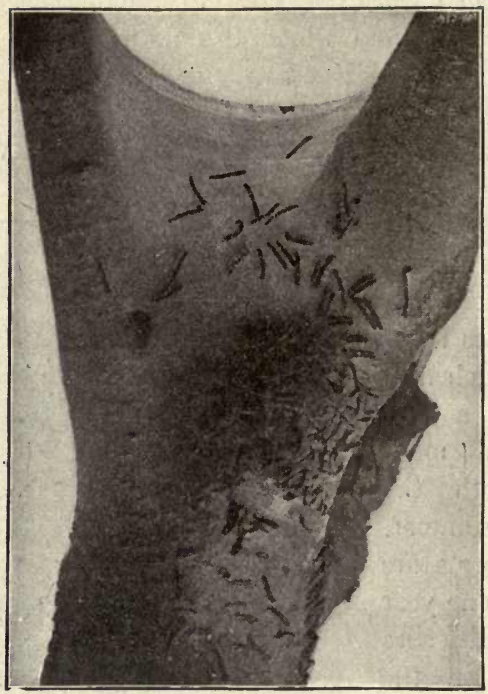

FiG. 78.-Photograph of tent caterpillars four days old on their tent. Natural size.

the first of which hatches from the white frothy eggs deposited by the wingless female in late autumn and remaining over winter on the trees. The eggs for the second generation are laid in late summer. In July and September, the light yellowish cocoons an inch or more long are conspicuous objects on the rough bark of the trees.

The gypsy moth (Ocneria dispar), occurring only in Massachusetts and Rhode Island, was accidentally introduced from France in 1868. The larva, a brownish hairy cater- 


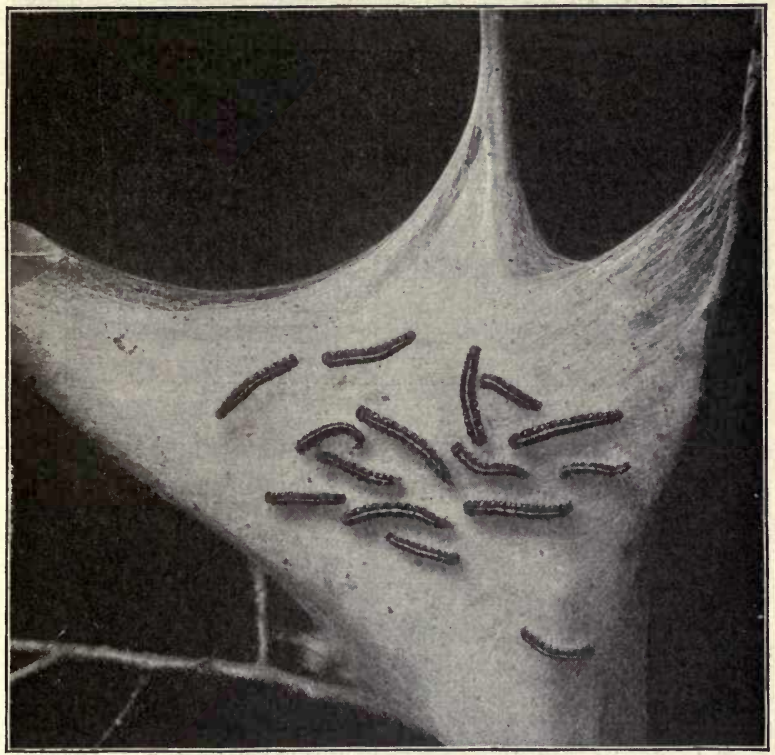

Fig. 79. - Photograph of mature forest tent-caterpillars on their tent. One third natural size.

pillar about an inch and a half long, feeds upon many kinds of trees and plants. Had prompt measures been used in the early seventies, the plague might have been exterminated, but owing to ignorance on the part of the legislators, no organized fight was made against the devastator until 1890. For holding in check this pest, the Massachusetts legislature appropriated in 1893 one hundred 


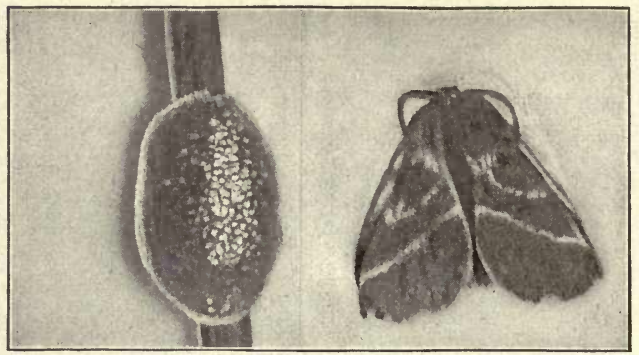

FIG. 80. - Eggs and moth of the tent caterpillar. Twice natural size.

thousand dollars, in 1894 the same amount, and the following year one hundred and fifty thousand dollars. Large appropriations have been made later, but the enemy still continues its ravages, and should it be carried to the other states à national calamity would result.

Owlet Moths (Noctuidæ). - These are usually of a somber gray or brown color and have a wing expansion of from one

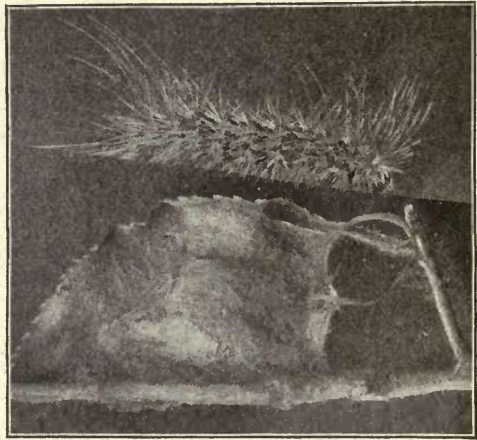

Frg. 81. - Photograph of fall webworm and its cocoon. Nearly twice natural size.

to three inches. The larvæ of many of the species are known as cutworms, because in the spring and early 


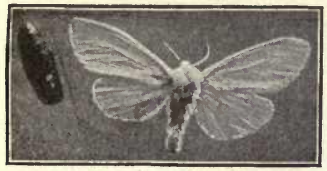

Fig. 82. - Photograph of pupa and moth of the fall webworm. Natural size.

summer they gnaw off the corn, cabbage, cotton, and other tender plants near the surface of the earth. Some species climb the trees and cut off the tender buds.

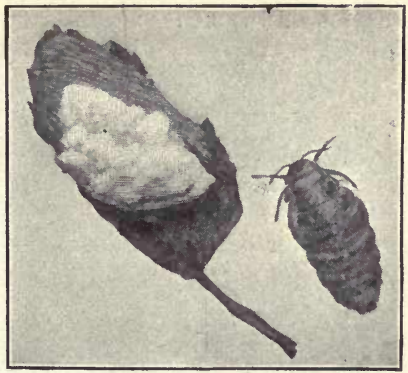

FIG. 83. - Female tussock moth which has just emerged from the cocoon at the left upon which it has deposited over two hundred eggs. Photograph, slightly enlarged. Both larvæ and adults are usually active at night only. The pupal stage is passed in the earth. In early spring the common gray cutworm may be found coiled up under

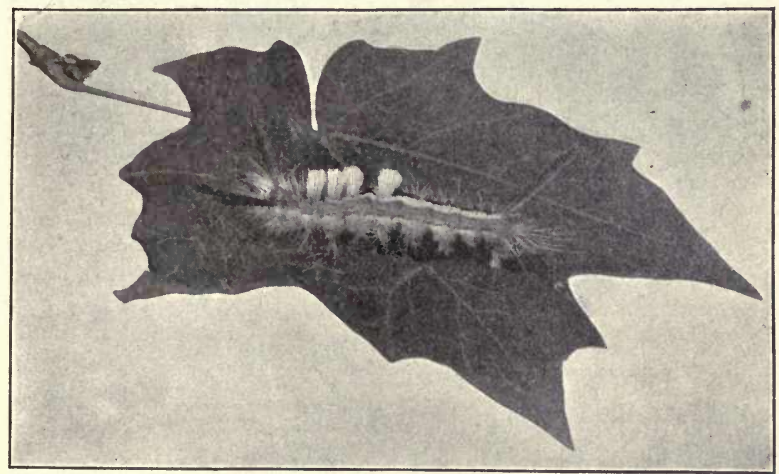

F1G. 84. - Larva of tussock moth. Photograph natural size. 
stones and boards, while later it and allied species may be found by digging about the base of any plant which has

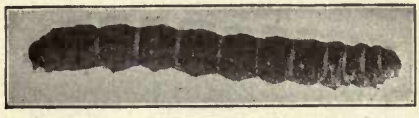

FIG. 85.-Common eutworm (Agrotis). Natural size. lately been cut off near the surface of the eartl:

Winter is passed in the larval state, and pupation occurs in the ground.

The cotton-boll worm or corn worm (Heliothis armiger) in 1902 damaged the cotton crop in Texas alone to the extent
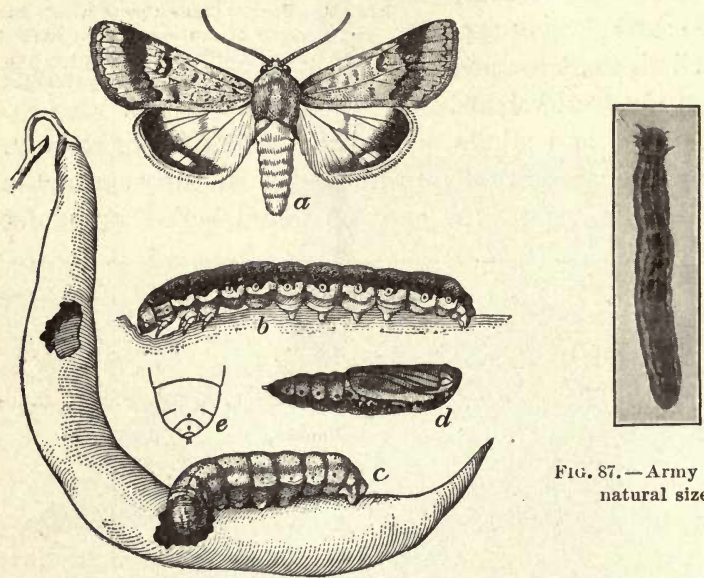

Fil. 87.-Army worm, natural size.

FrG. 86. - Cotton-boll worm or corn worm. Two larvæ, pupa, and adult. After Chittenden.

of four millions of dollars, and in 1893 to the extent of five millions of dollars. It also attacks other plants, especially the ears of sweet corn. The army worm (Leucania uni. 


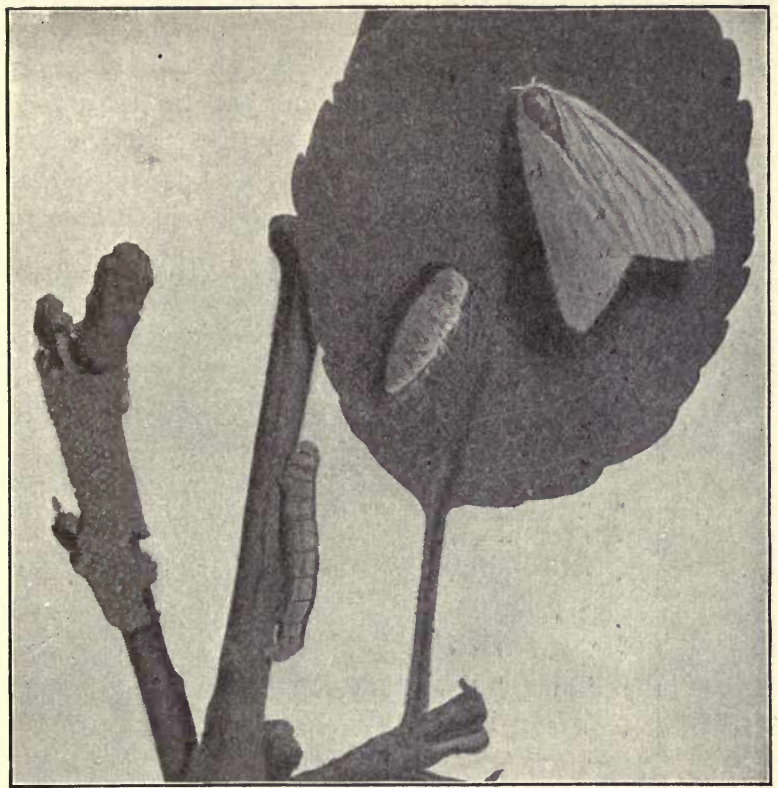

'IG. 88. - Photograph of the eggs, larva, and moths, male and female, of the fall canker worm. Enlarged slightly.

puncta) often travels in armies composed of millions of individuals which destroy acres of vegetation in a single day. The adult is a gray moth.

Measurers (Geometridæ). - The larvæ of these moths are called measuring worms, and may be distinguished by their characteristic walk, which consists of attaching the three front legs and then elevating the middle portion of 
the body to form a loop as the hind legs are brought forward. Of the many species the most injurious ones are the canker worms. There are two kinds. The fall canker worm (Anisopteryx pometaria) ruins the leaves of the orchards in certain localities in the northern parts of our country during the month of June. The pupal state is passed in the earth within a dense yellow silken cocoon,

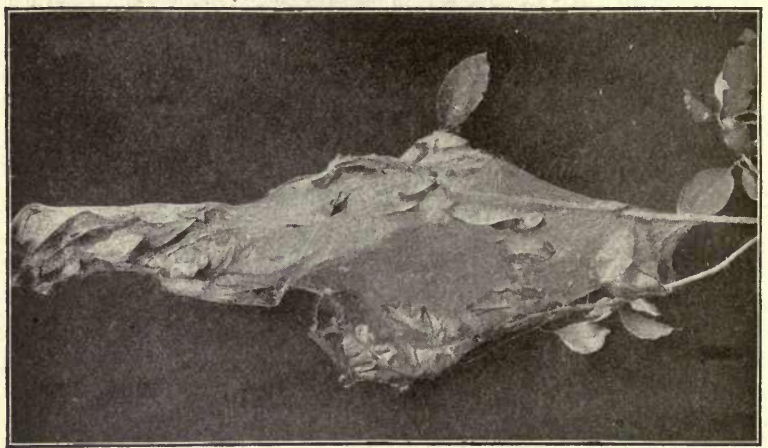

FIG. 89. - Photograph of a colony of oak-leaf rollers. One sixth natural size.

from which the moth comes forth in late autumn to deposit three or four hundred eggs on the limb of a tree. The female moth is wingless, and therefore the pest spreads over new territory slowly: The spring canker worm, similar to the fall species, is common in the Mississippi valley and throughout the West.

Leaf Rollers (Tortricidæ). - These constitute a family of rather small moths whose larvæ often roll up the edges of the leaves and line the interior with silk to form a cocoon. Some species, such as the oak-leaf roller (Cacocia fervidana), 
live in colonies forming webs in midsummer, within which they pupate.

The coddling moth (Carpocapsa pomonella) is familiar to most pupils in its larval form as the whitish worm found in apples, pears, and quinces. About a week after the trees bloom the brownish-gray moth emerges from its silken cocoon beneath a loose piece of bark and lays a minute white egg on each of fifty or more leaves and apples. In less than two weeks the larva enters the fruit at the blossom

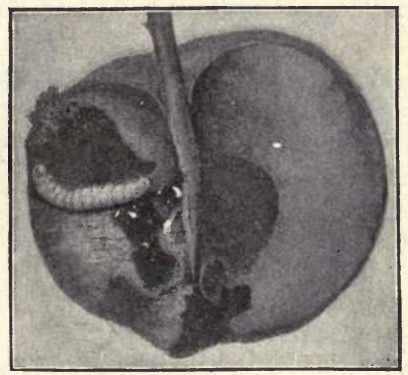

FIG. 90. - Photograph of half an apple containing the larva of the coddling moth. Nearly twice natural size. end and eats out a large cavity, causing it to fall to the

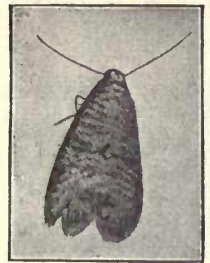

FIG. 91. - Coddling moth. Photograph, slightly enlarged. ground. Soon after, the worm finds a secluded spot, constructs a cocoon in which it remains a fortnight before transformation to the adult moth is completed. In regions north of the latitude of Buffalo the larva remains in its cocoon over winter, but farther south there are usually two generations and the larva of late summer only remains over winter. The pupa and adult are easily obtained by removing a large larva from an apple in June and feeding it daily in a covered jar with fresh apple until it spins a cocoon. 
The damage this pest causes annually in Illinois has been estimated at $\$ 2,375,000$, in Nebraska $\$ 2,000,000$, and in New York $\$ 3,000,000$. Not a state in the Union is exempt from its ravages, which are somewhat limited by the woodpeckers, and may be almost entirely avoided

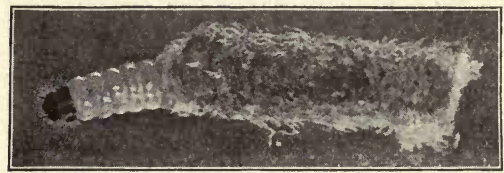

FIG. 92.- Larva of clothes moth (Tinea pellionella) half out of its case. Photograph, three times natural size. by spraying the trees in accordance with directions furnished by the United States Department of Agriculture.

Tiny Moths (Tineidæ). - These are small moths with pointed and fringed wings. Most important among them are the clothes moths, of which there are two common species.

The southern clothes moth (Tineola biselliella) is of a pale-yellowish color without spots. Its larva, a hairless white worm a half inch long, feeds upon museum specimens, furs, feathers, and hair. The ordinary clothes moth (Tinea pellionella) may be distinguished from the above species by the less pointed

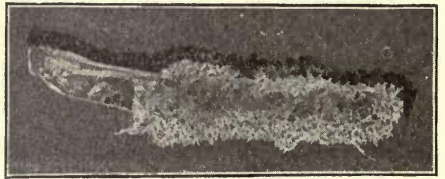

FIG. 93. - Empty pupa case of the clothes moth. wings and the presence of a few dark spots on the anterior wings. The white naked larva weaves a cocoon which is carried about and enlarged to meet the growing demands of the inmate. Finally within this cocoon the larva trans- 
forms to the pupa, lasting about three weeks. The moths emerge from May to August, take no food, and after depositing their eggs on any woolen material, soon die. The larvæ feed upon all sorts of woolen goods. In winter they may be often found in their woven cases adhering by their ends to the lids of boxes or the ceilings of rooms.

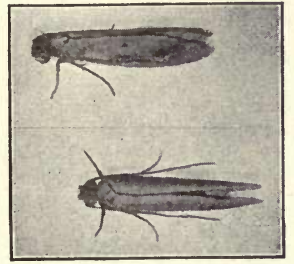

FIG. 94.-Clothes moth (Tinea pellionella). Photograph, twice natural size.

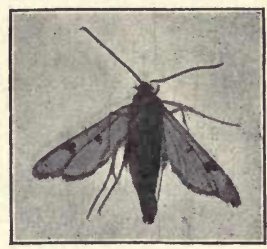

Fig. 95. - Moth of the maple borer. Natural size.

Clear-winged Moths (Sesiidæ). - These are wasplike moths of brilliant colors and have transparent wings. They generally fly by day. Their larvæ live in the stems of herbs and shrubs or the trunks of trees. Usually each species confines its depredations to a certain kind of plant or tree. The empty pupa cases of the maple borer (Sesia acerni) may be seen protruding from round holes in the soft maples during the month of June. The squash borer may often be found during early summer in dead and dying squash, pumpkin, melon, and cucumber vines, just beneath or at the surface of the ground. It is a widespread pest.

The moth of the peach tree borer (Sanina exitiosa) deposits during May, June, or July one or more yellowish 
almost invisible eggs on the bark of stone-fruit trees near the ground. The white larva bores into the tree, feeding on the sap wood near or below the surface of the ground, and making its presence known by the exudation of gum and fragments of borings about the base of the tree. By late autumn it is almost an inch long, and it then remains dormant until the following spring. The approach of warm weather again stimulates it to feed a few weeks and

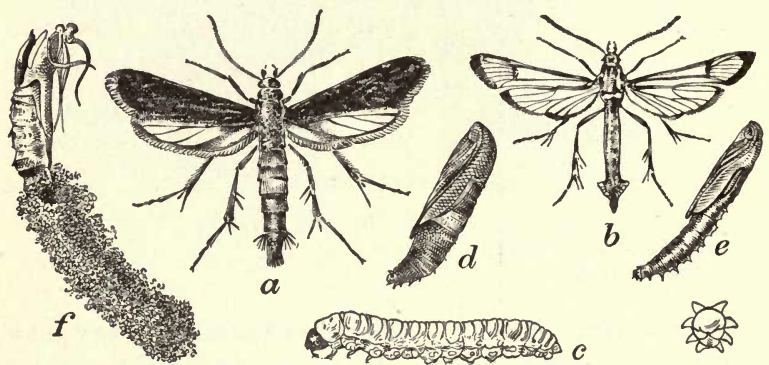

FIG. 96. - Peach tree borer ; $a$, female moth ; $b$, male moth ; $d$ and $e$, pupæ ; $c$, larva ; $f$, chip cocoon with extruded pupa skin. Natural size, after Marlatt.

in late spring or early summer its transformation to pupa and adult is accomplished within a chip and gum cocoon at the base of the tree.

Metamorphosis among the Lepidoptera is complete, i.e., there are four well-marked stages, the egg, larva, pupa, and imago or adult. In some species the eggs hatch a few hours after being laid, while in others they remain over winter. The larva of most species, except those of the measuring worms, have eight pairs of legs of which the three anterior are known as true legs because they become 
the legs in the imago. The others are called false or prop legs. The larva is a voracious creature, often eating its own weight of food in a day. Its senses of taste and feeling are well developed, but the other senses appear quite rudimentary. Three simple eyes on either side of the head enable it to discern light from darkness.

The shedding of the skin, called molting, occurs usually four or five times, and in many species the last larval skin forms the cocoon in which transformation to pupa and adult is effected. The larvæ of the butterflies never spin cocoons, but those of the moths, with the exception of the ones pupating in the earth, generally form cocoons either from the hair on their bodies or from the secretion of certain glands. The larval state in most species continues one or two months, but in certain species it lasts more than a year. In the pupal stage the insect appears as if dead. Freezing temperature for months does not harm it. The period during which the various species remain in this condition is from a few days to a year. The imago of many species takes no food, while in others, such as the hawk moths and some butterflies, it sips nectar or sap through its proboscis formed by the greatly developed maxillæ. The mandibles which chew the food in the larval state are too small for use.

\section{HEMIPTERA}

The members of this order are the true bugs whose mouth parts are adapted for piercing and sucking. They can not bite or chew. Nearly thirty thousand species have been described, and among them are found the greatest enemies of the human race. 


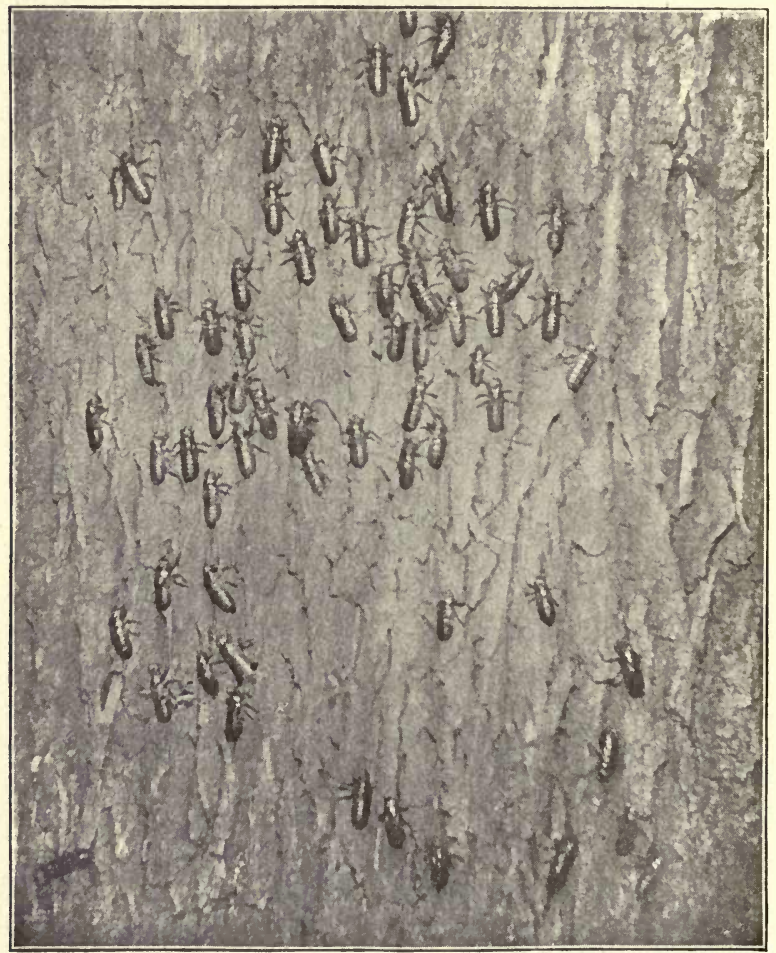

FrG. 97. - Seventeen-year cicadas ascending an asl. tree at 8 P. M. Flash light photograph, one fourth natural size. 


\section{Harvest Flies (Cicadidæ)}

The cicadas, wrongly called locusts, are the largest representatives of this order. The most celebrated of the several species is the seventeen-year locust (Cicada septendecim),

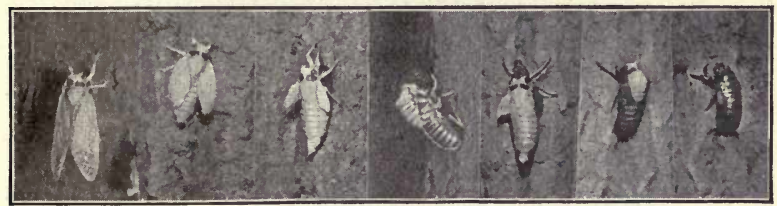

FIG. 98. - Seventeen-year cicada showing metamorphosis from nymph to adult as it occurred between the hours of 9 P. M. and 10.30 P.M. Flashlight photographs, one half natural size.

which appeared in vast numbers in seventeen states during 1902. During the last days of May just at sundown under

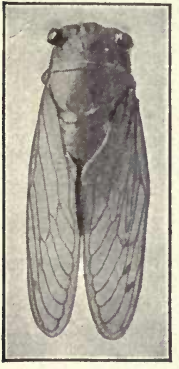

FiG. 99. - Seventeen-year cicada. Natural size. the trees the numerous young, called nymphs, peeped out of holes in the earth, and a few minutes later came forth, walked to the nearest tree, ascended some distance, and fixed their claws firmly in the bark in preparation for molting. A fissure appeared in the skin of the backs from which issued the adult white cicadas. The wings slowly expanded and the changed creatures proceeded toward the upper branches, where at daylight they became of a dark hue and forced their beaks through the tender bark in quest of sap.

In July the love song of the males, sounding much like the rattle of the rattlesnake, made such a din in the 


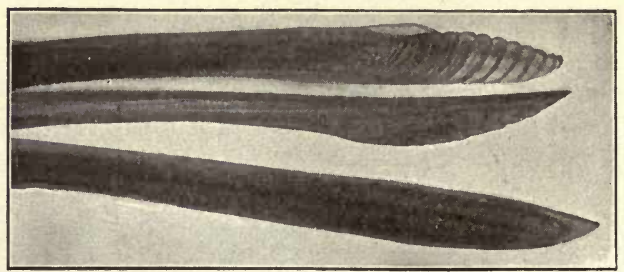

FIG. 100. - End of the ovipositor of a cicada showing below the two saws used to make the insertion for the eggs. Photograph enlarged twenty times.

forests that a person could not hear his companion speak at a distance of ten feet. The noise is produced by the drum present only in the male beneath the front part of the abdomen. A few days later the females

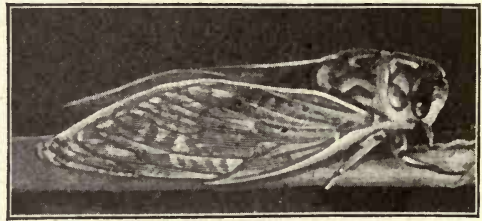

FiG. 101,-Annual cicada with its beak inserted in a twig. with the saws of the ovipositor cut slits in the tender

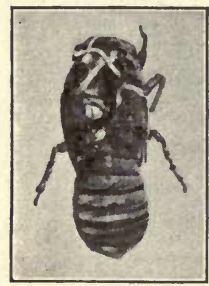

FiG. 102. - Pupa skin of cicada. branches to deposit numerous eggs which hatched a few days later, and the antlike young descended into the earth to remain sixteen years feeding on the sap in the roots or absorbing nourishment from the humus in the soil. These insects never sting, as many suppose, and cause but little damage to trees.

The annual cicada (Cicada tibicen), also known as the jar fly or dog-day fly, 
because it appears in August, completes its life round in only two years. The numerous pupal or nymph cases seen on the trees in late summer are of this species.

\section{Plant Lice (Aphidæ)}

The plant lice have a remarkable life history. Most of them pass the winter in the egg state. At the first

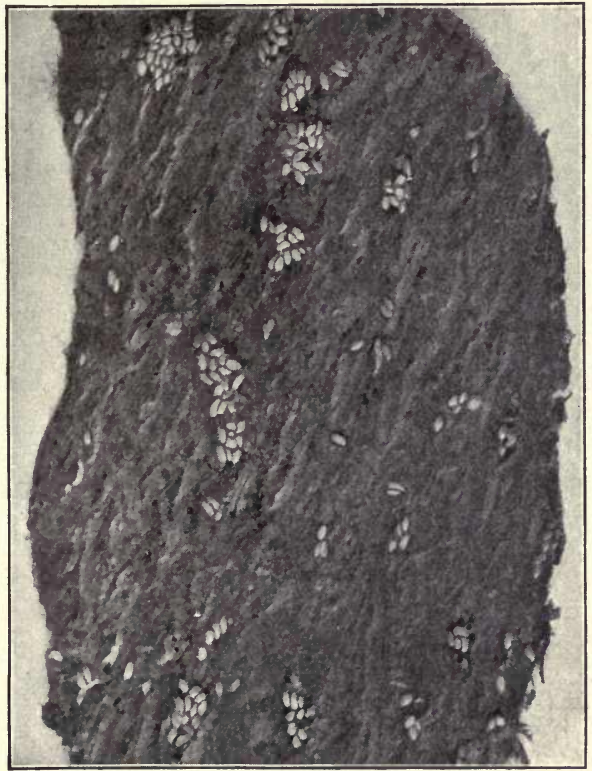

FiG. 103. - Eggs of plant lice on a maple tree in October. Photograph three times natural size.

appearance of leaves in the spring, the eggs hatch into wingless females, no males being found until late in summer. 
The females bring forth living young at the rate of from three to ten daily for nearly a fortnight and sometimes longer. In two weeks after birth the young generations are sufficiently mature to become the mothers of several daughters daily. Later in the season some of these develop wings, and at the approach of cold weather males are born,

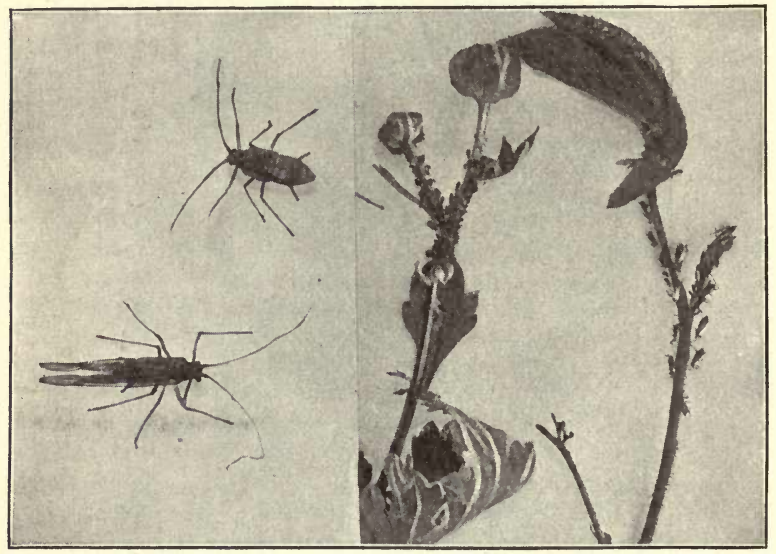

Eıs. 104. - Plant lice. Those on the left are enlarged twice, those at the right sucking juice are natural size. Photographs.

some of which also have wings. In October and November, the female deposits numerous fertile eggs which remain over winter and hatch into stem mothers the following season. So rapidly do the plant lice breed that were it not for their natural enemies, the birds, minute parasitic flies, syrphus flies, and lady bugs, they would destroy most of the vegetation. 
The grape-vine louse (Phylloxera vastatrix) is said to have cost the French more than the indemnity paid to the Germans after the Franco-Prussian war. Its damage in this country is not great.

The hop louse (Phorodon humuli) is the great enemy of the hop industry. Aphis rosa makes the raising of roses

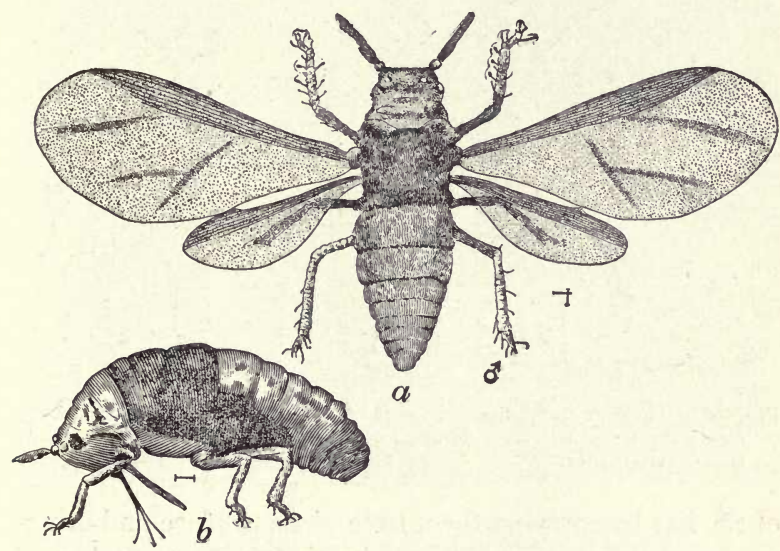

FIG. 105. -Grape-vine Phylloxera ; $a$, adult ; $b$, young. After Marlatt.

difficult in some regions. The maple louse blights young maples. Aphis mali stunts many young apple trees. The cherry aphis (Myzus cerasi) lives on the cherry from April till June, and feeds on another plant the rest of the season. The green pea louse along the Atlantic coast in 1900 destroyed peas to the value of four millions of dollars. In 1899 the wheat louse damaged the wheat badly in many sections. 
The several species of Aphidæ bearing a white cottony growth are known as wooly plant lice. In all there are over a thousand species of Aphidæ. Many of them give forth from the alimentary canal a honey dew much sought after by the ants, which often care for the eggs and young
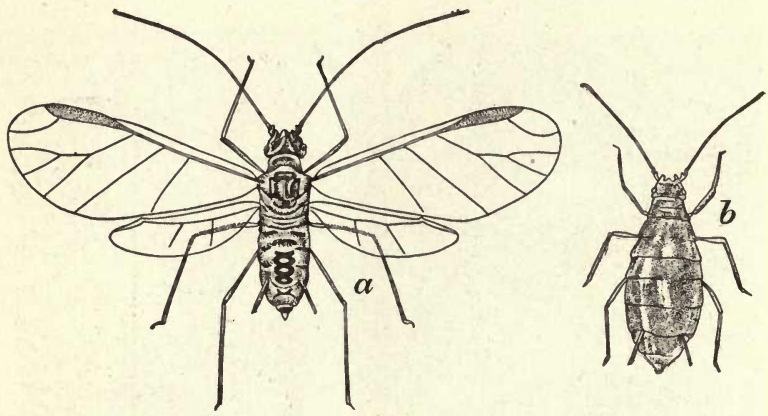

FrG. 106. - Hop louse which lives on the plum tree in late fall, winter, and early spring until the hop vines develop; $a$, male; $b$, female. Fnlarged twenty times. After Riley.

of the lice by carrying them from place to place and otherwise protecting them. Plant lice are therefore spoken of as the ants' cows.

\section{Scale Insects or Bark Lice (Coccidæ)}

The individuals of this family are easily recognized by the fact that the female and sometimes the male dwell beneath a scale varying in size from one fiftieth of an inch to a fourth of an inch in diameter. The scale is formed by the molted skins and excretions of the insect.

Pernicious or San Jose Scale (Aspidiotus perniciosus.) - 
This scale may be studied to the best advantage from July to November. It is distinguished by its circular form with a minute peak at the center, and a red color beneath the

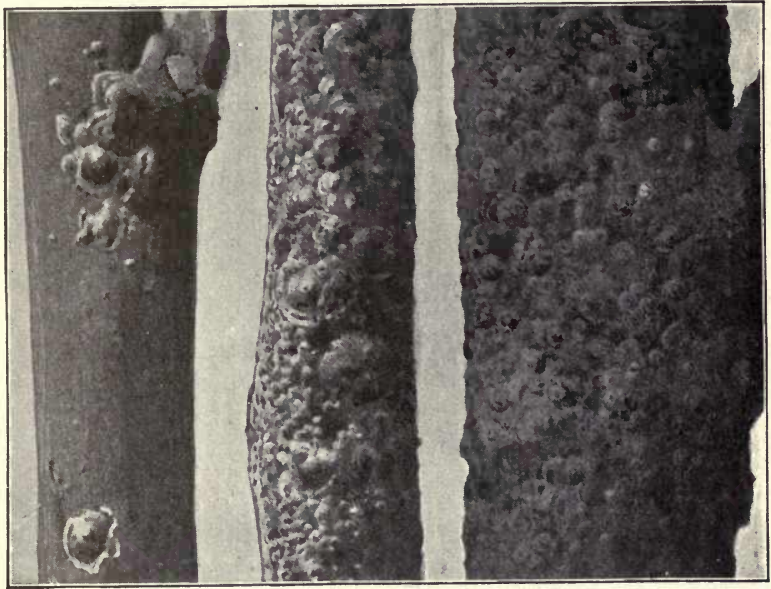

FiG. 107.-San Jose scale. The two limbs at the right are completely covered, while the one at the left has only five large scales and several small ones. Photograph ten times natural size.

bark or fruit supporting it. The scales may not be perfectly round, especially on the leaves, and the peak may be absent on some of them. The insect winters in a halfgrown state, being a mere disk of yellow covered by a minute black scale. It begins to feed in the early spring by sucking the sap through its beak so tightly stuck in the twig that it can never be withdrawn. By June numerous young may be seen within the mother if examined under 
the microscope, and during the latter part of the month in the latitude of Pittsburgh they give birth to living young which crawl out from the scale, and during the next

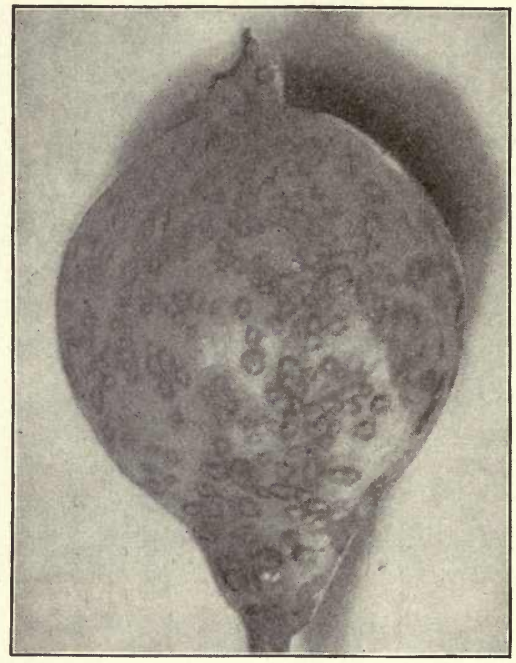

FIG. 108. - San Jose scale on a pear. Photograph natural size.

two days appear to the naked eye as minute yellowish specks slowly wandering over the branches. After a free life of about forty hours, these larvæ insert the beak firmly into the bark from which they never remove it. The exudations of the insect's body form the scale. The young are ready to reproduce in one month, and bring forth during the next three weeks about five hundred living young. 
As from three to six broods mature during a season, a single insect may be the mother of one hundred million young from June to December.

Their only way of spreading is by being carried on the feet of birds, by various insects, and by the wind. The purchasing of infested trees may also be the means of introducing the pest into a locality. It attacks most fruit trees, currant bushes, English walnut, osage orange, and numerous other shrubs, which are usually killed within two or three years by the poison in-

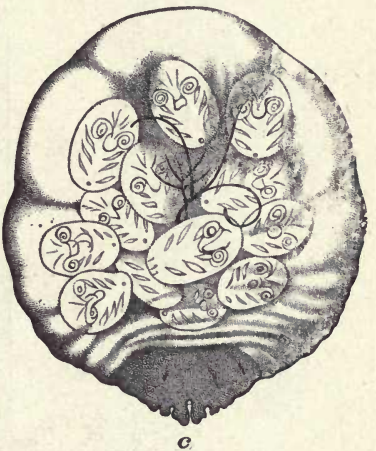

FIG. 109. - Female San Jose scale insect removed from the scale. Several young are seen within. Enlarged fifty diameters. After Howard. jected into them and the loss of the sap. The greatest

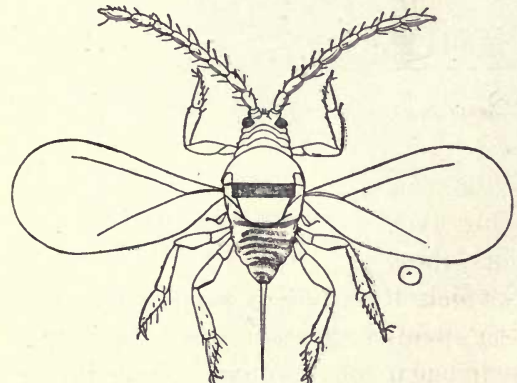

FiG. 110. - Male San Jose scale insect enlarged about fifty diameters. After Howard. natural enemy of this scale is the two-spotted ladybird beetle brought by the government agents from China, the home of the scale. Numerous artificial remedies, directions for using 
which may be secured free from the United States Department of Agriculture, will keep the pest in check.
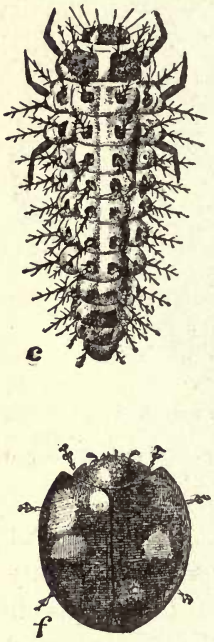

FIG. 111. - Asiatic ladybird imported to devour the San Jose scale. $c$, larva ; $f$, adult. Enlarged four times. After Marlatt.

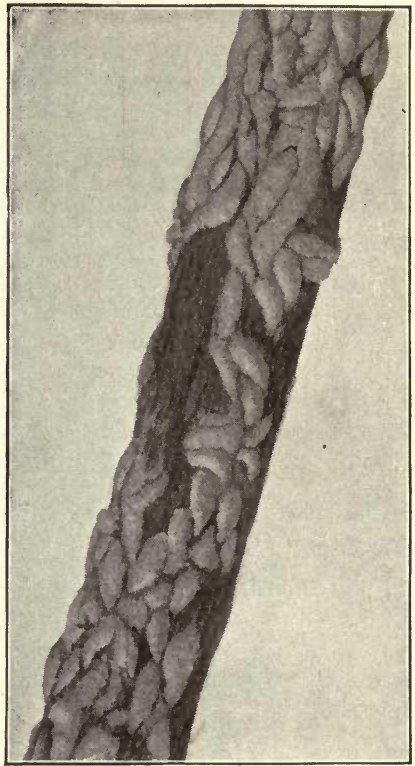

FrG. 112. - Oyster-shell scales, three of which have holes showing where Chalcis flies escaped after destroying the contents. Three times natural size.

The oyster-shell bark louse (Mytilaspis pomorum) is not so serious a pest as the pernicious scale. It brings forth only one brood annually, and remains over winter in the egg state. 
The scurfy bark louse, with a scale twice as long as wide, impoverishes the apple trees in some localities. The rose scale (Diaspis rose) is an enemy of the roses and blackberries, but it is kept in check by parasites.

The armored scales are represented by the maple scale and the poplar or tulip tree scale. The covering of the insect is not a true scale, but a waxy secretion. The common hothouse mealy bug is also a familiar. species of the Coccidæ. The only useful member of this large family is the cochineal insect (Coccus cacti) feeding on the cactus in Mexico, Central America, and other tropical regions. These creatures are dried and powdered to form the

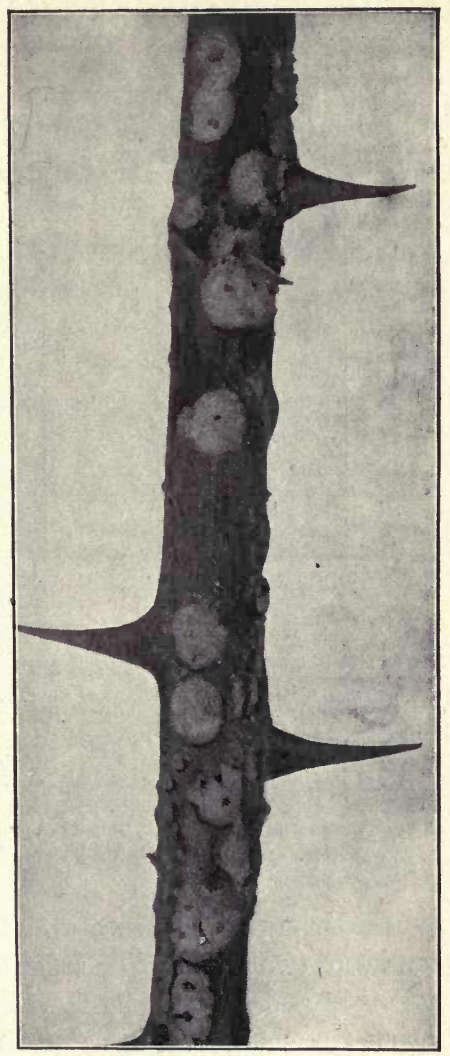

Fig. 113.-Rose scale. Large round ones are females and the few small elongate ones are males. Enlarged three times. 
famous cochineal dye from which carmine is extracted.

The true bugs (Heteroptera) contain several species of considerable interest to man. They possess a beak permitting them to feed on the juices of plants or insects, or

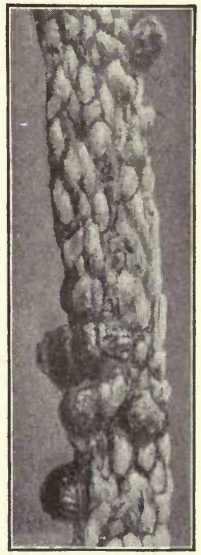

FTG. 114. - Maple scale, five adults and many young. Photograph enlarged twice.

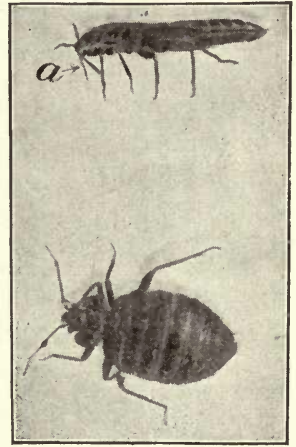

Fig. 115. - Bedbug viewed from the side and back; $a$, beak used in piercing the skin and sucking the blood. Photograph enlarged twice.

on the blood of vertebrates. The wings when present consist of two pairs. The anterior ones function as elytra or covers, and have the basal half thickened, a feature from which the name of the order, Hemiptera (half-winged), is derived.

The bedbug (Cimex lectularius), found in all parts of the world, is able to live a year or more without food. This 
fact, together with its flat body permitting it to hide in the smallest crevices, makes extermination difficult when a house is once infested with them. As they have no wings their usual method of entering a house is on articles of clothing. The idea that they are associated with bats and pigeons is a mistaken one, although a similar bug is a parasite on the bats.

The assassin bugs, many of which have beaks strong enough to pierce the human skin, include the kissing bugs. Of these Reduvius personatus living in dirty basements and feeding on bedbugs and roaches, is common throughout this country. It is a fierce biter, occasionally attacking man and sometimes causing serious sickness, owing to the germs on the dirty beak.

The chinch bug (Blissus leucopterus) causes an annual loss to the grain and grass crop of nearly twenty millions of ciollars. It passes the winter in clumps of grass or other protected places, and in the spring lays about five hundred eggs in the grass sheaths near the ground. The young as well as the adults are gregarious. A second generation develops from eggs laid in August. The species occurs over the entire eastern half of the

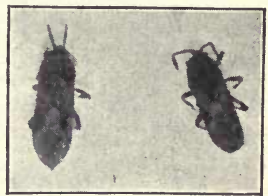

FIG. 116. - Photograph of chinch bugs enlarged three times. United States, but it is most destructive in the Central States, the Carolinas, and Virginia.

The ill-smelling squash bug (Anasa tristis) renders the squash, melon, pumpkin, and cucumber crop an uncertain one in many localities, while the harlequin cabbage bug destroys millions of cabbage plants annually. The water 
boatman (Notonecta) and the giant water bug (Belostoma) are the two common aquatic members of this order.

The pupil must remember that there is a wide difference between bugs and beetles both in their external appearance and habits. The most significant difference in structure is in the mouth parts, which should be examined in some large bug such as the squash bug. In this species the piercing

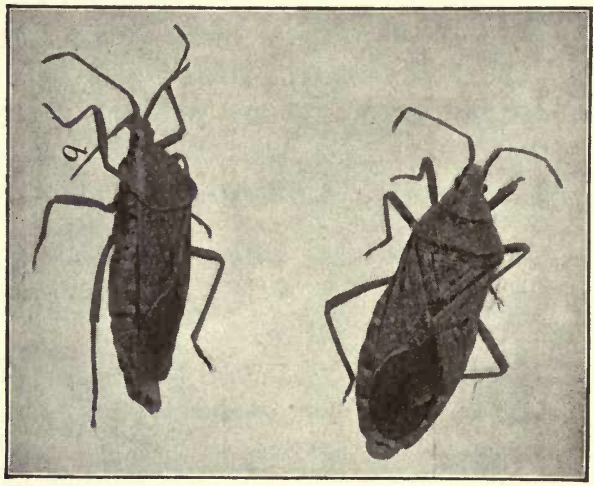

FIG. 117. - Squash bug viewed from the side and back; $b$, beak used in piercing and sucking the juice of the vines. Photograph enlarged three times.

and sucking beak is more than a quarter of an inch long, and is folded close to the ventral side of the body when not in use. At the base of the beak is the labrum, while in a groove on its upper part lie two pairs of hairlike processes, the shorter of which are the mandibles, and the longer are the maxillæ. The sheath inclosing these is made by the labium and labial palpi. The bugs are capable only of piercing and sucking food, and can not bite. 


\section{COLEOPTERA}

The members of this order are distinguished by the presence of elytra (hardened wing-covers) which meet in a straight line down the middle of the back. More than one hundred thousand species are known.

The snout beetles or weevils (Rhyncophora) comprise over four thousand species, all of which are injurious. The plum curculio (Conotrechelus nenuphar) is familiar to every one in its larval state as the footless white grub present in so many plums, cherries, and apricots, causing the unripe fruit to fall to the ground. The larva then enters the earth, soon becomes a quiescent pupa, and a fortnight later has completed its transformation to an adult beetle. It may

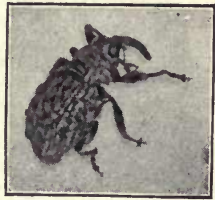

FIG. 118.- Photograph of plum curculio enarged three times. be found on the plum and cherry trees from May until August. An easy method of col-

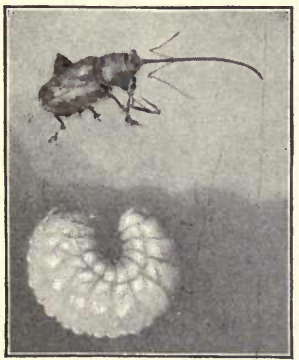

Frg. 119. - Photograph of larva and adult nut weevil enlarged three times. lecting them is to hold an open umbrella or sheet beneath the tree and shake it vigorously.

The nut weevil (Balininus) is easily recognized by its long snout. Chestnuts harboring the larvæ of this weevil are spoken of as being wormy. The eggs are laid in August or September, and the larvæ leaving the chestnuts in late autumn enter the ground to $\mathrm{pu}$ pate and remain until the next 
season. The pea weevil (Bruchus) is often found in peas in its larval state during summer and autumn, as a pupa

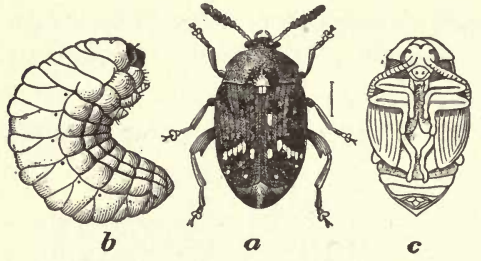

FIG. 120. - Pea weevil ; $a$, adult ; $b$, larva ; c, pupa. Enlarged five times. After Chittenden. in winter, and in the adult form in late spring, when it comes forth to lay its eggs on the pods of the growing peas. To find the weevil in the fall, soak peas in water for a day. This causes most of the affected seeds to float. The grain weevil (Calandra) is a pest in mills and granaries, devouring the inside of the grains of wheat.

The cotton-boll weevil (Anthonomus grandis) threatens to make cotton raising a very uncertain business. The pest becaine so troublesome in Texas that the governor offered a reward of fifty thousand dollars to any one who

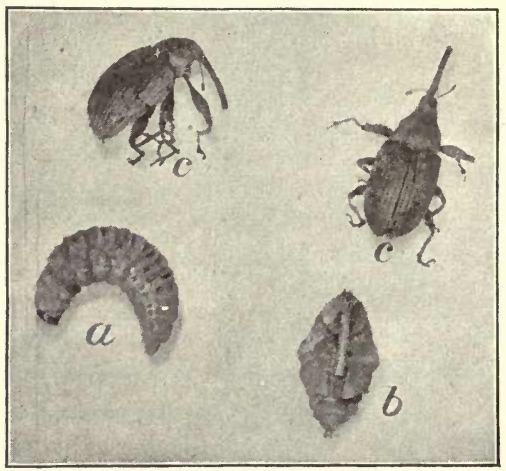

FIG. 121.-Cotton-boll weevil ; $a$, larva ; $b$, pupa ; $c$, adult. Photograph enlarged four times.

should discover a remedy to prevent the ravages of the insect, which amounted to twenty millions of dollars annually. 
The strawberry weevil (Anthonomus signatus) in certain seasons has prevented the development of more than a half crop of berries in New Jersey, Delaware, Maryland,

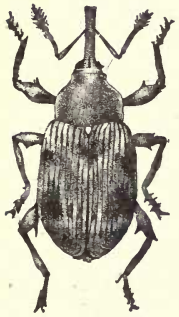

Fig: 122. - - Straw• berry weevil enlarged seven diameters. After Chittenden.

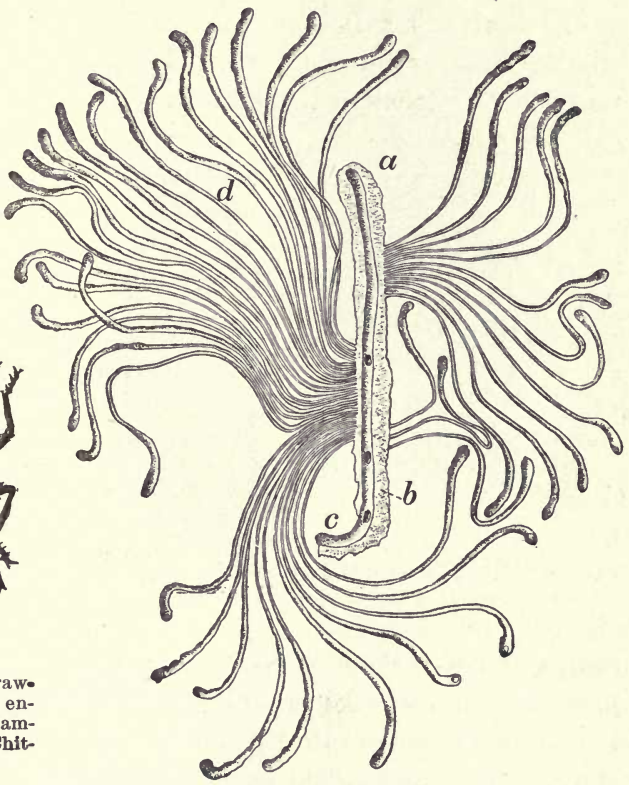

FIG. 123. - Galleries of the spruce-destroying beetle beneath the bark of a spruce tree. After Hopkins.

the Carolinas, and Virginia. The eggs are deposited in the flower buds, upon which the grublike larva feed and attain full size in about a month.

The bark beetles are short-snouted weevils which breed 
just beneath the bark of many species of trees and excavate characteristic galleries. It is estimated that they damage timber to the extent of fifty millions of dollars annually.

The Lamellicorn Beetles are characterized by antennæ ending in from three to seven flat segments. They are much less destructive than the weevils. The commonest
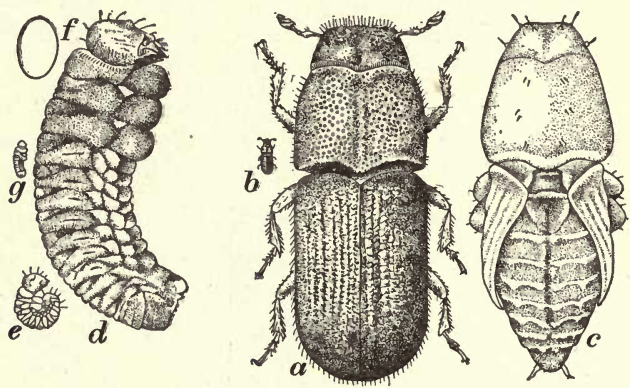

FIG. 124. - Pine-bark beetle whose work has made pine lumber expensive; $a$, adult ; $c$, pupa ; $d$, larva. Small figures are natural size. After Hopkins.

representative is the May beetle or June beetle (Lachnosterna fusca) of a brown color and more than a half an inch long. It is often attracted into the house at night by the lighted lamp. The eggs are laid on grass near the ground where they hatch into minute six-legged white grubs with brown heads. They burrow into the earth, feed on the roots of grasses for two years, and having attained a length of nearly two inches are known to most people as white worms or grubs. Transformation to pupa occurs in the fall and the adult issues the following spring. The stag beetle 
(Lucanusdama) presents a life history similar to the June beetle, but the larval and pupal stages are passed in decaying wood.

TheLongicorn Beetles (Cerambycidox) form a family including eight thousand species whose larvæ are wood borers tunneling through trees. The adults are characterized by

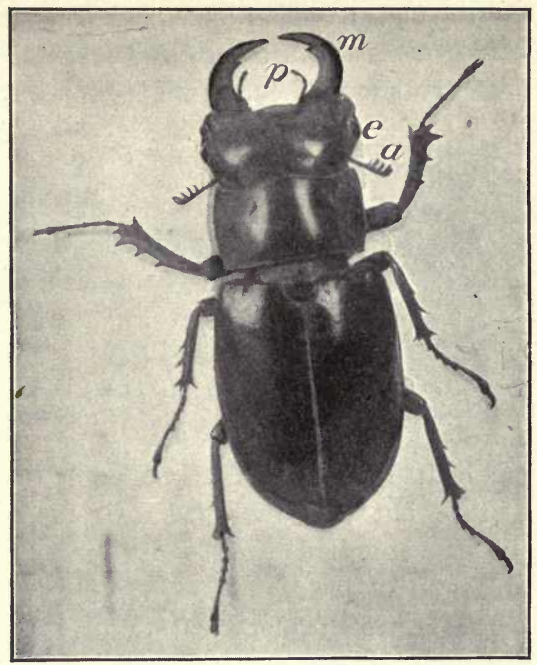

FrG. 125. - Stag beetle; $a$, antenna ; $e$, eye; $m$, mandible $p$, palpus. Photograph natural size. long, many-jointed antennæ. The locust borer (Clytus

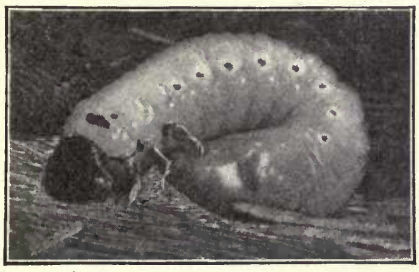

Fig. 126. - Larva of the stag beetle. Black spots on the side are spiracles. Photograph natural size. robinia), whose white, grublike larva lives in the locust tree, may be found in September on the golden rods. The apple tree borer issues as an adult from the apple tree in July and may be recognized by the two yellowish stripes 
on its elytra. The pine tree borer may live in wood made into furniture for fifteen years. The maple borer destroys annually many maple trees. It is well for the

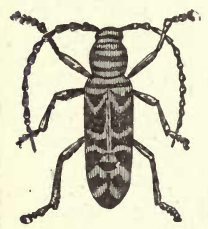

FIG. 127. - Beetle of the locust borer.

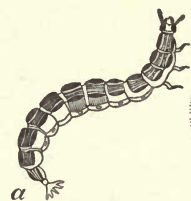

FIG. 128. - Firefly or Lightning bug; $a$, larva; $b$, pupa ; $c$, adult.

pupil to remember that not only the larvæ of many beetles, but also the larvæ of some of the Lepidoptera and Hymenoptera dwell within living trees.

The Serricorn Beetles including several thousand species, have serrate antennæ of medium length. The larvæ vary in their habits. The firefly or lightning bug (Photinus pyralis) passes its larval life in the earth feeding on earth worms and softbodied insects. It pu-

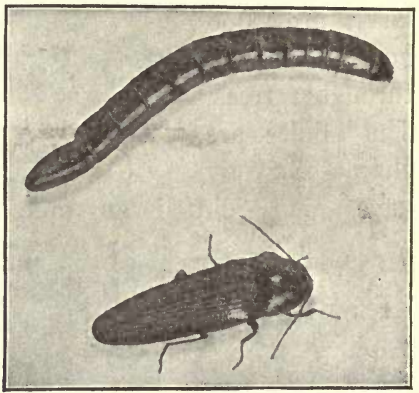

FIG. 129, - Click beetle and its larva. Slightly enlarged. pates in a cocoon of earth, and transforms to the adult state in June, when it comes forth and flies about by night emitting a strong light from the lower side of the posterior 
part of the abdomen. The larva of a larger species lives above ground and is known as the glow worm.

The click beetles, making up the family Elateridæ, may be recognized by the characteristic click which they give to right themselves when placed on their backs. The larvæ, called wire worms, live under the bark of trees, in rotten wood, or upon the roots of herbs. They have a rather hard, brownish skin and three pairs of legs. They are plentiful and easily found in rotten logs. In summer and autumn the beetles feed on the flowers.

The Clavicorn Beetles are characterized by club-shaped antennæ. The buffalo moth or carpet beetle (Anthrenus

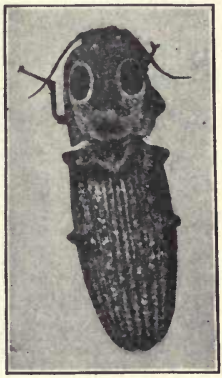

FIG. 130. - Eyed elater, the largest of the click beetles. Photograph natural size. scrophularice) is present in nearly every house with tacked-
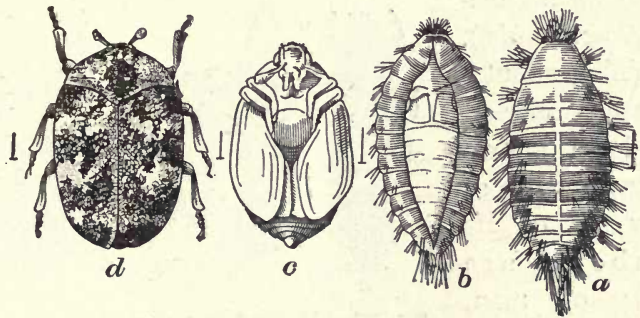

FIG. 131. - Buffalo moth or carpet beetle; $a$, larva; $b$, pupa within larva skin; $c$, pupa ; $d$, adult. Enlarged eight times. After Riley.

down woolen carpets. The small larva bristling with brown hairs may be found under the edge of a carpet not recently 
cleaned, at almost any time of the year. It feeds on any kind of woolen material. It is probable that there are two broods a year, but the beetles are most frequently seen on

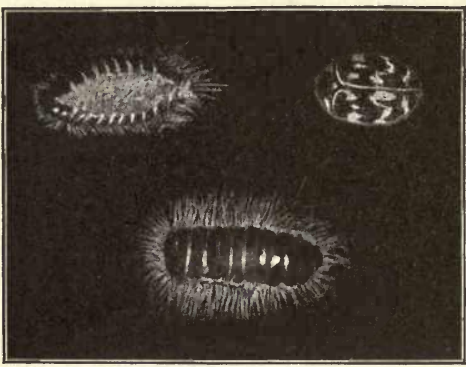

FIG. 132. - Museum pest (Anthrenus varius). Larva below the open pupa case, and adult above. Photograph enlarged three times. the windows in April. A similar beetle, the museum pest (Anthrenus varius), destroys many kinds of dried museum material. Carbon bisulphide, a fourth of an ounce to each cubic foot, will destroy any of these beetles or their

larvæ if the box or closet containing them is closed tightly for a day.

The ladybird family (Coccinellida), containing about a thousand species, should be known to every one, as nearly all of its members are friends of man. They are of a more or less hemispheri-
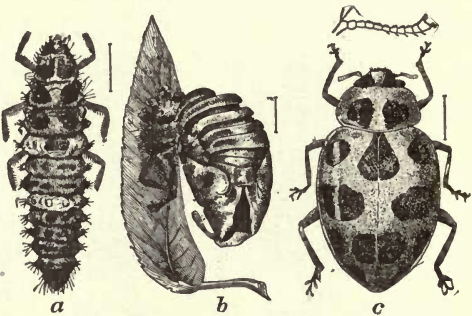

FIG. 133. - Ladybird beetle; $a$, larva; $b$, pupa; $c$, adult. Line at the right shows natural size. After Chittenden.

cal form, and usually of a red or yellow color with round or lunate black spots. The larvæ, which are 
most abundant in June and July, consume great numbers of plant lice. In some places in California the destructive orange scale has been entirely kept in check by a species of ladybird beetle, and lately the Asiatic ladybird imported from China is proving a great destroyer of the San Jose scale. The beetles pass the winter in the adult state, often coming into houses, where they should be protected.

The Leaf-eating Beetles, numbering ten thousand species, are injurious to garden vegetables and many shade trees. The

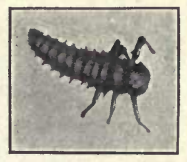

Fig. 134. - Larva of ladybird beetle twice natural size.

best known of these are the Colorado potato beetle, the asparagus beetle, and the elm leaf beetle, whose depredations cost millions of dollars annually. The Colorado potato beetle dwelt near the base of the Rocky Mountains until 1859 when it began to be a pest in the potato fields of the western settlers. Having acquired the habit of feeding upon the potato, it spread rapidly, reaching the Atlantic coast in 1874 . The pest is easily kept in check by spraying the potatoes with Paris green and water or sprinkling them with fifteen parts of flour to one part of Paris green.

The Coleoptera exhibit a complete metamorphosis, but the forms and habits of the larvæ vary widely. Some dwell underground, some thrive on decaying wood, and some prey on other insects. With the exception of the ladybirds, and carrion beetles whose larvæ feed on decaying flesh, the members of this order are mostly injurious. Instead of taking food by sucking, as is the habit of all the bugs, they chew their food and are therefore readily killed by spraying the vegetation with poisons. 


\section{NEUROPTERA, EPHEMERIDA, AND ODONATA}

A typical example of the Neuroptera is the hellgramite (Corydalis cornutus) whose larva, the black crab, or dobson,

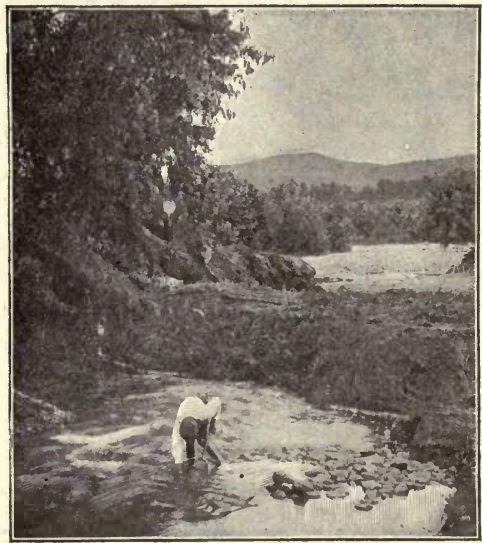

FIG. 135. - Catching the larvæ of hellgramites. is the favorite among fishermen as a bait for black bass. It is found under $\log s$ and stones in the shallow water of clear streams, which it leaves in late spring to hide under some object on the bank and to transform to a naked pupa. A week or more later it assumes the adult form which may often be caught around the electric lights at night. The egg deposits form conspicuous white spots the size of a nickel on

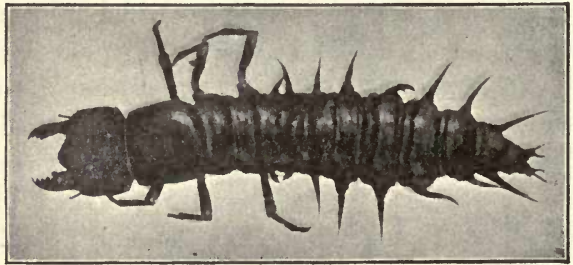

FIG. 136. - The dobson, natural size. 
the lower sides of logs, rocks, and trees overhanging the water, where they may be found during June and July. The young drop into the water, and during the larval stage of nearly three years feed on aquatic insects. Respiration is accomplished by the several pairs of tufts on either side of the abdomen.

Other well-known members of this order are the ant-lion and the aphis-lions or lace-wing

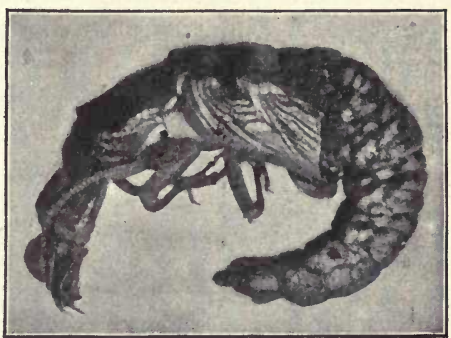

FrG. 137.-Pupa of the hellgramite, natural size. flies. The larvæ of these as the names suggest feed upon ants and plant lice,

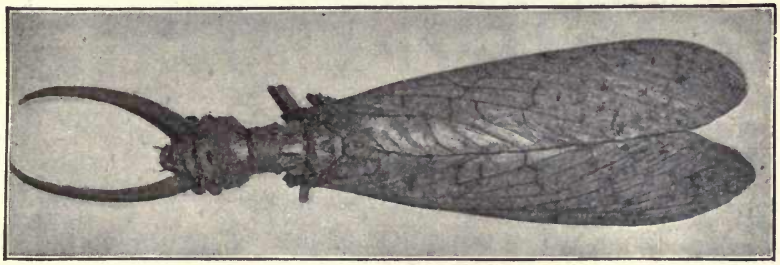

FIG. 138. - Hellgramite, natural size.

and may be found in places frequented by their prey in June and July.

The May Flies (Ephemerida). - The members of this order are distinguished by their short antennæ, large front wings and small hind ones, and two or three slender fila- 
ments at the end of the abdomen. The larvæ of all the species live in the water, feed upon vegetable matter, and breathe by means of gill tufts. The larval life lasts from one to three years during which large numbers are eaten by fish. Metamorphosis to the adult form takes place in May and June when the adults sometimes become so numerous along the watercourses that the dead may be picked up by the handfuls where the waves wash them up on the

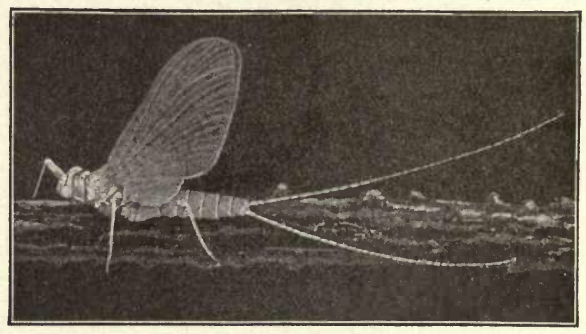

Fig. 139. - May fly, twice natural size.

shore. The pupa or nymph is active and much like the larva in form, except wing pads are present.

The adults take no food as the mouth parts are atrophied and the alimentary canal is not fitted for digestion. They usually live only a day or two.

Dragon Flies (Odonata). - All the numerous species of this order have a similar life history which is easily studied in any one of our dozen common kinds. The nymph or larval stage may be found almost any time of the year in mud at the bottom of ponds, and if large specimens are removed to the aquarium in May and fed daily with fresh 
beef, mosquito larvæ, or bits of earth worm they will be seen to molt. In some cases the nymph (pupa) will climb a stick or stem of a water plant during a night in June, and early the following morning from a slit in the skin of its back the adult insect will come forth. In midsummer

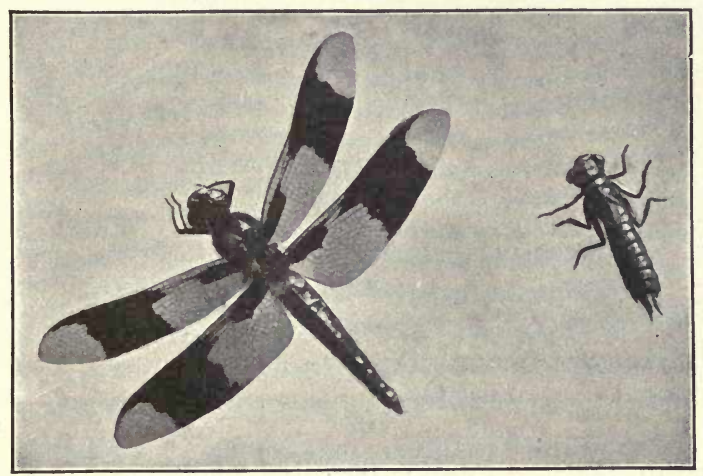

FIG. 140. - Dragon fly and larva (Plathemis lydia). Photograph natural size.

the eggs are laid on the surface of the water or on some object beneath the surface.

Most dragon flies alight with expanded wings, but a group of the more slender-bodied ones resting with wings folded goes under the name of damsel flies. So far as known all dragon flies, otherwise called devil's darning needles, snake feeders, and snake doctors, are harmless and beneficial insects. The larvæ feed on mosquito larvæ and other aquatic forms, while the mature insect consumes large numbers of mosquitoes. To note one's appetite hold it by 


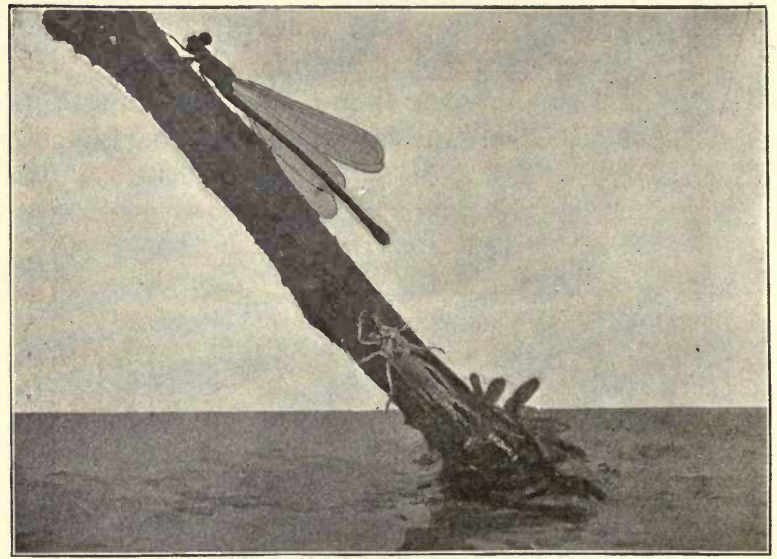

Fig. 141. - Photograph of a damsel fly just out of the pupal skin below. Natural size.

the wings pressed together over its back and feed it house flies of which it will devour as many as two dozen in a few minutes.

\section{Characteristic Features of Insects}

The insects agree in having a segmented body composed of three clearly defined parts, the head, thorax, and abdomen. The head bears two hairlike processes, the antennæ, a pair of large compound eyes, and several ocelli or simple eyes. The wings varying in number from none to two pairs are attached to the thorax and present nervures or veins. These are air tubes or tracheæ. The legs, of which 


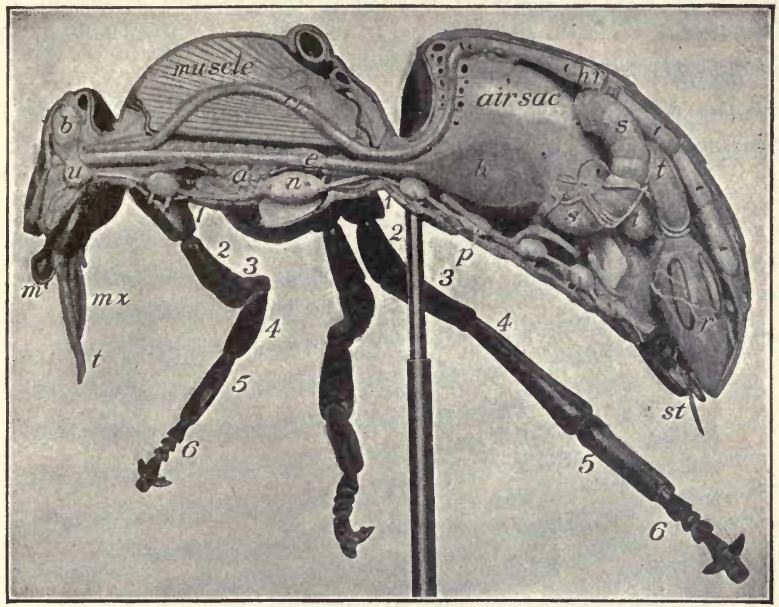

FIG. 142.-Photograph of a model to show the strusture of the honey bee; $a$, salivary gland; $b$, brain ; $e$, esophagus; $h$, honey stomach ; $h r$, heart with five cross slits through which the blood enters ; $t$, tongue ; $m$, mandible ; $m x$, maxilla; $n$, one of the eight ventral ganglia made of nerve cells and connected by white nerve cords ; $p$, poison gland ; $r$, rectum or end-portion of the intestine ; $r t$, aorta or mainblood vessel ; $s$, true stomach ; $s t$, sting; $t$, intestine surrounded by white tubes, the kidneys; $u$, ventral head ganglion.

there are never more than three pairs, are joined to the thorax. All insects having a complete metamorphosis pass through four stages in their life history known as the egg, larva, pupa, and imago. Some forms, such as the Orthoptera, Hemiptera and Odonata, are said to exhibit an incomplete metamorphosis because the difference in form between the larva and pupa is not very marked. The young of these orders is therefore often called a nymph. The larval form of the Lepidoptera is named a caterpillar, 
that of the Coleoptera, a grub; that of the Diptera, a maggot. The larva of some families has as many as sixteen legs, while in others there are from six to twelve, and in the weevils no legs are present.

As the structure of the various insects is so similar, a

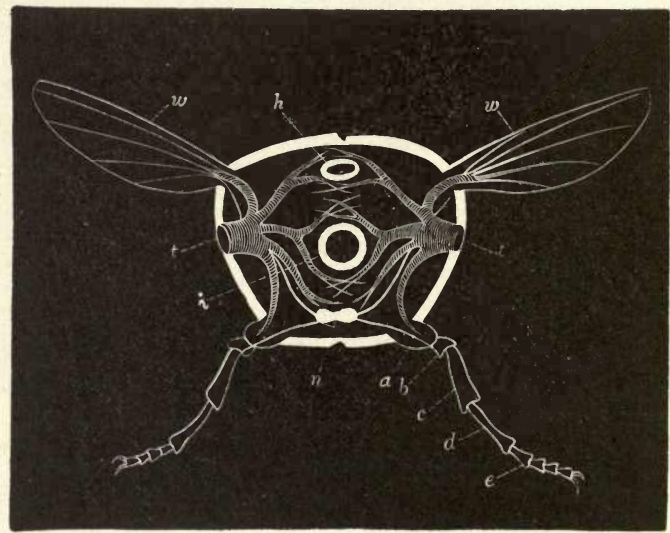

FrG. 143. - Diagrammatic eross section of a grasshopper enlarged three times ; $h$, chief blood vessel; $i$, intestine; $n$, ganglion of the nerve cord; $t$, stigmata or spiracle for the admission of air to the branched tracheal tubes; $w$, wings; $a$, coxa ; $b$, trochanter ; $c$, femur ; $d$, tibia ; $e$, tarsus.

study of any form will serve to give a general knowledge of the anatomy of all. Large locusts or grasshoppers are easily secured, and can be dissected to advantage if preserved in seventy per cent alcohol (commercial alcohol three parts and water one part). To dissect, place in a pan with water sufficient to cover and fix to the wax-covered 
bottom with two pins, the one passing very obliquely through the head and the other through the hind part of the abdomen. Cut away with scissors the dorsal portion of the body wall and immediately beneath it note a lightcolored threadlike tube, which is the heart. Ramifying among the muscles are the trachece appearing as minute slender white tubes, which examined in a drop of water under the microscope show spiral thickenings. If near egg-laying time the female will have much of her abdomen filled with the two ovaries containing many eggs. Two small tubes, the oviducts, pass from the ovaries to the posterior ventral side of the abdomen, where they unite.

The digestive canal is a tube extending in an almost straight course from the mouth to the posterior end of the body. The much enlarged portion in the thorax is the crop which receives the food from the esophagus opening from the mouth. The stomach lies next to the crop and leads into the intestine. Several blind pouches, called cæca, project forward from the stomach.

The nervous system is not easy to observe, but if all the other organs are removed from the body, a white mass of nerve matter, a ganglion, about the size of a pinhead may be found on the floor of the thorax and from it two nerve cords extending forward to the mouth where they pass around the esophagus to a large ganglion, named the brain. Two cords also pass backward from the thoracic ganglion through the abdomen and bear several ganglia. All ganglia are collections of nerve cells, whose processes, the fibers, form the cords. 


\section{Importance of Studying the Insects}

The necessity of investigating the habits and structure of insects in order that we may be able to control them is well presented in the following abstracts taken from the writings of Slingerland:

A very conservative estimate puts the yearly loss from insect depredations in the United States at one tenth of all the farm crops, and this amounts to the enormous sum of $\$ 300,000,000$, and this is only about $\$ 52$ for each farm. A recent estimate by experts put the yearly loss from forest insect depredations at not less than $\$ 100,000,000$. The common schools of the country cost in 1902 the sum of $\$ 235,000,000$, and all higher institutions of learning cost less than $\$ 50,000,000$, making the total cost of education in the United States considerably less than the farmers lost from insect ravages.

Furthermore, the yearly losses from insect ravages aggregate nearly twice as much as it costs to maintain our army and navy; more than twice the loss by fire; twice the capital invested in manufacturing agricultural implements; and nearly three times the estimated value of the products of all the fruit orchards, vineyards, and small fruit farms in the country.

We dare not hazard a guess and have no data on which to base an estimate as to how much American farmers are now spending in time and money in the warfare against their insect enemies. It would surely aggregate a sum that would startle us. But at least one hundred and twentyfive entomological workers are now devoting most of their energies and spending probably $\$ 250,000$ in the United 
States in studying injurious insects and devising methods for preventing such enormous losses to American farmers. Massachusetts spent more than a million dollars in trying to exterminate the gypsy moth, and Congress has just appropriated $\$ 250,000$ to fight the boll-weevil and other troubles in southern cotton fields. Farmers are trying to feed to insects over two thousand tons of Paris green annually in the United States.

The statistics for New York state also offer some interesting comparisons along this line. The total value of all farm and forest crops, excluding animal products, in New York, in 1899 , was $\$ 150,000,000$, and the one tenth that the insects got was worth $\$ 15,000,000$. It may seem incredible that it costs such a sum to feed New York's injurious insects every year, but it is an average of only $\$ 66$ for each of the 227,000 farms in the state; and there are few farms where the crops are not lessened more than this amount by insects. It is admitted that the codling moth alone ruins $\$ 3,000,000$ worth of apples and pears yearly in the state, and in 1901 the Hessian fly took half of New York's wheat crop, thus robbing the farmers of $\$ 3,500,000$.

\section{ARACHNIDA AND MYRIAPODA}

The Arachnida, including the spiders, scorpions, and mites, are distinguished from other arthropods by the presence of four pairs of legs, the division of the body into two parts, called cephalo-thorax and abdomen, and the absence of antennæ. From two to six pairs of eyes are just visible on the upper part of the forehead. No ears have been 
found, and as none of the group make any noise they probably can not hear.

The first pair of mouth appendages are the chelicerce, terminating in claws at whose ends poison glands open. The idea that the bite of a spider which is made by the cheliceræ is dangerous, has no foundation in fact. In most of our common species the terminal claw is scarcely long enough to reach through the skin, and the poison is not sufficient to cause any discomfort. Occasionally dirt

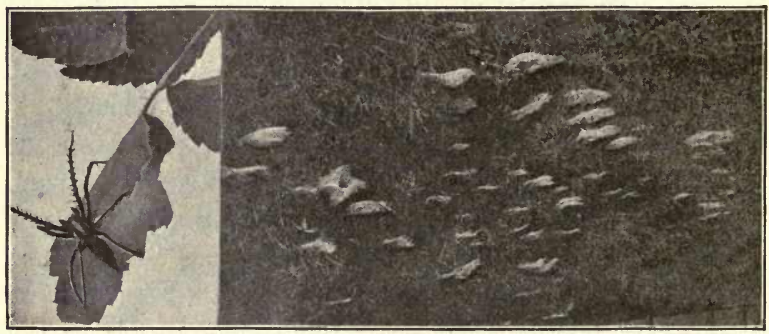

FiG. 144. - Agalena, the grass spider. At the right is a photograph of its webs as seen on a dewy morning; at the left the spider with its cocoon of eggs in the overlapped leaf photographed natural size.

getting access beneath the skin with the poison may cause an inflammation. The large spiders of the South, the tarantulas, possess large fangs and enough poison to make their victim quite sick.

The second pair of mouth parts, looking like legs, are the pedipalps. On the ventral side of the abdomen near its stalk attachinent to the cephalo-thorax may be seen a pair or two of slits opening into the lung sacs. These consist of small cavities across which hang about a dozen lamellæ 


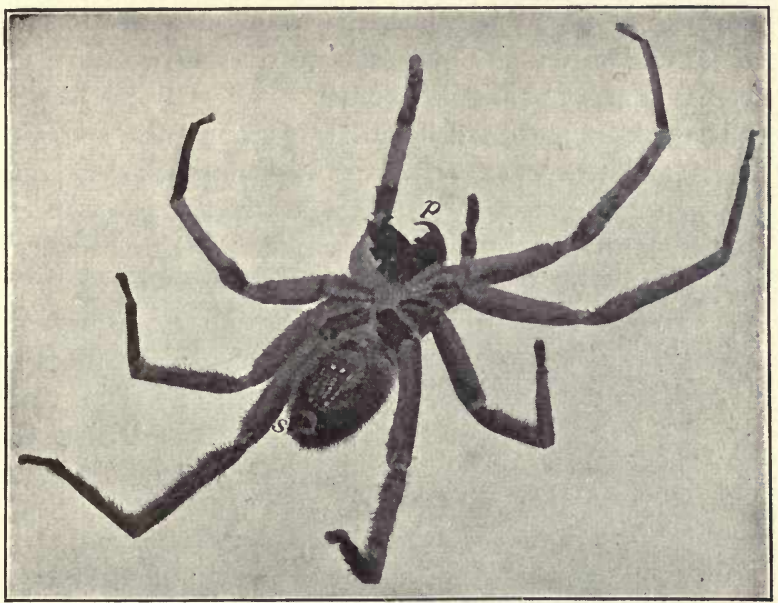

FIG. 145. - Lycosa on its back; $p$, poison fang ; $s$, spinneret. Photograph natural size.

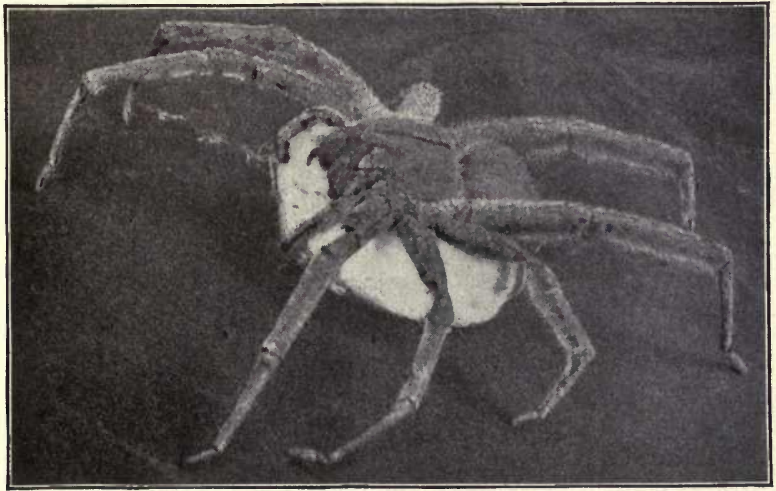

FIG. 146. - Lycosa with its cocoon of eggs. Photograph natural size. 
or plates of tissue, in which the blood circulates to give off its carbon dioxide and take up oxygen necessary for the life of every part of the body.

The spiders are divided into two groups, the spinners.

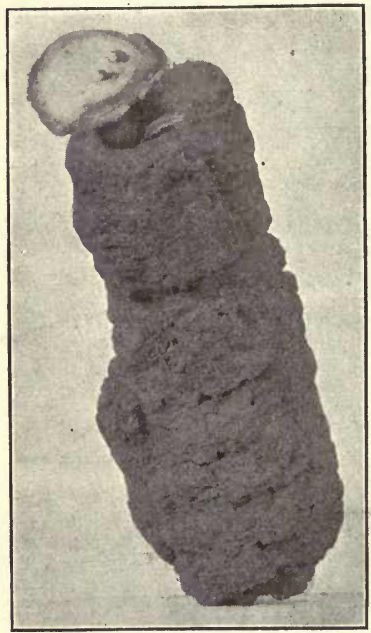

FiG. 147.- Photograph of the nest of a Texas trapdoor spider with the door open to the left. or sedentary spiders, and the non-spinners, or wandering spiders. Of the spinners there are four kinds.

The tunnel weavers are those which make tubes in the earth and line them with silk. Some such as the trapdoor spiders of Texas and California have sufficient skill to make a door to close the entrance against intruders.

The tube weavers make the webs so conspicuous in the grass on a dewy morning. At one side of the web a tube extends toward the ground. Some of these species spin quite dense webs in corners of deserted buildings and in bushes.

The line weavers are those which construct irregular webs known as cobwebs.

The orb weavers work with mathematical precision, spinning spirals supported by numerous radii. The male orbweaving spider is much smaller than the female which 
sometimes becomes so angered with her mate as to kill and eat him.

The silk with which spiders work is formed by glands in the abdomen, which open by two or three pairs of prominences, the spinnerets at the posterior part of the abdomen. The excretion passing out of these several orifices unites

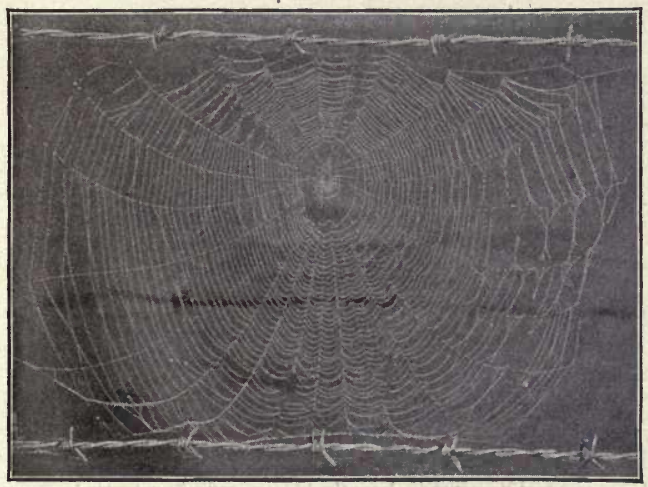

Fru. 148. - Epeira, the common garden spider on its web. Photograph one half natural size by Charles Morris.

to form a single thread. The chief use of spiders' silk is for cross hairs in telescopes.

The wandering spiders never spin complete webs, but wander about buildings and fields. Our common species are rather large, and the female carries with her the small, round cocoon containing the eggs or young. Most spiders deposit their eggs, often numbering nearly a hundred, in cocoons, where they hatch in about two weeks, and the stronger young prey on the weaker for several days, so 
that not more than a dozen individuals survive. In some species the young pass the winter in the cocoon.

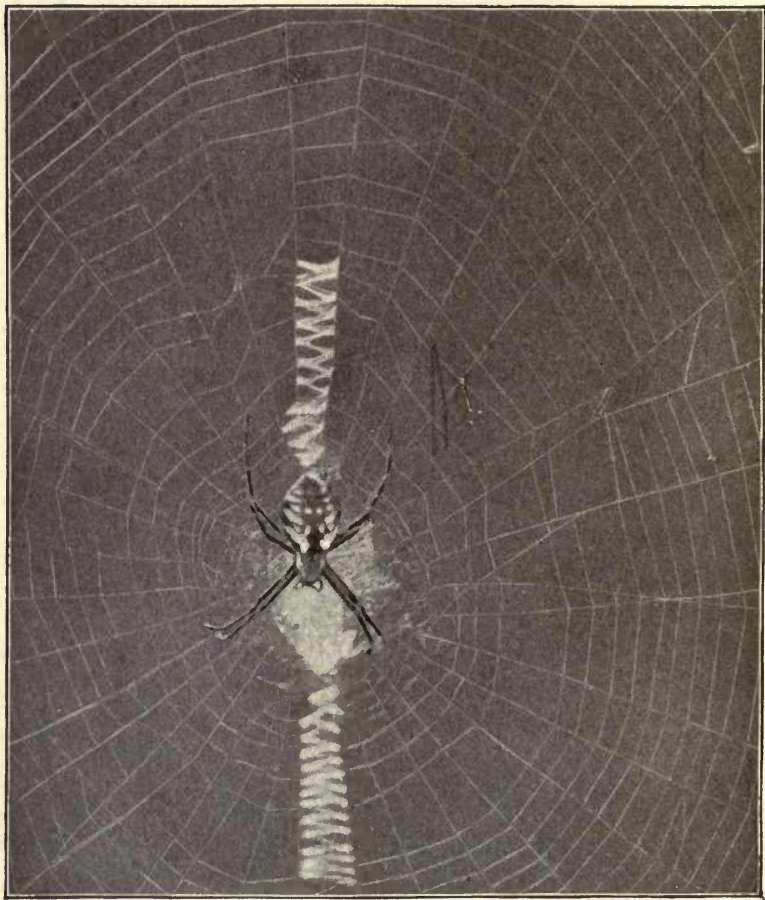

FrG. 149. - Argiope, the large orb weaver just completing the spinning of the winding stair. Photograph two thirds natural size.

The harvestmen or grandady-long-legs are beneficial members of this group as they feed largely on harmful insects. 
The itch mite (Sarcoptes scabei), causing the itch in man, and Demodex folliculorum, the parasite sometimes present

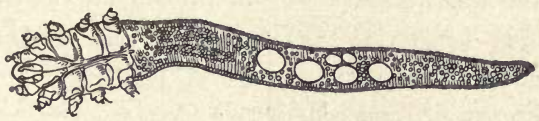

FiG. 150. - Demodex folliculorum enlarged one thousand times. After Selenka.

in the human hair follicles, are Arachnida much changed on account of their parasitic habits. The minute jigger

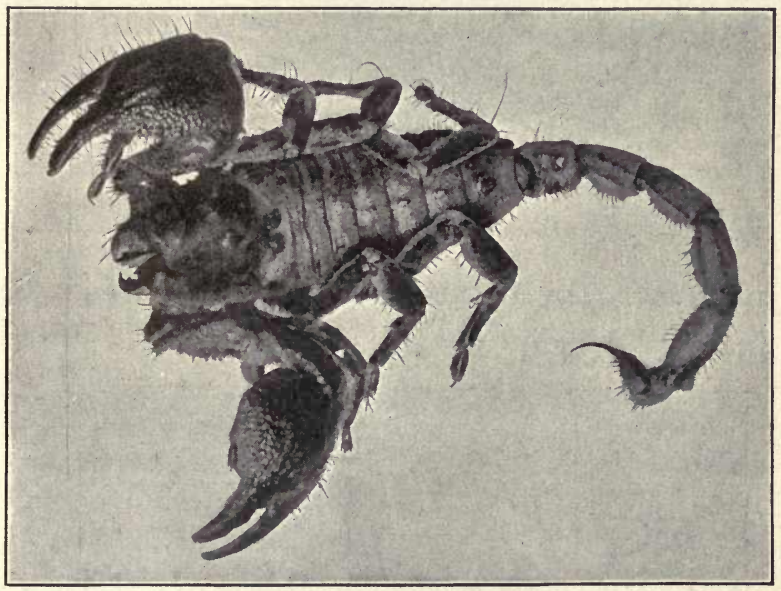

FIG. 151. - Scorpion showing the sting at the posterior end. Photograph natural size.

or chigger, so numerous in old berry patches in the Southern and Central States, often causes great inconvenience by burying itself beneath the human skin. 
The scorpions, usually with an elongated abdomen at the end of which is a sting and the opening of a poison gland, dwell in the warmer parts of our country and other tropical regions.

\section{Myriapoda}

The members of this class are characterized by an clongated body consisting of only two regions, the head

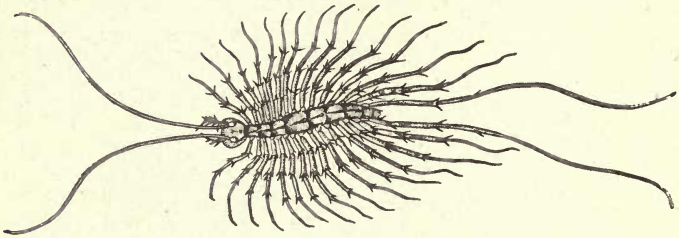

Frg. 152. - Scutigera forceps, a harmless centiped. Natural size. After Marlatt.

and trunk. The latter bears one or two pairs of jointed feet on each segment. They are divided into two groups,

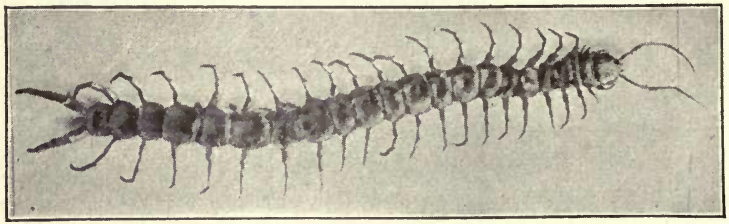

FiG. 153. - A poisonous centiped from Texas. Half natural size.

one of which, the centipeds, includes those forms having a single pair of legs to each body segment, while the other, the millepeds, have two pairs of legs to each segment. 
Scutigera forceps is a common centiped seen running about in dark cellars or basements. It is entirely harmless. Other harmless centipeds are found under logs and stones. Scolopendra is the genus of the poisonous centipeds of the South, the West Indies, and South America. They are from six to ten inches long, and with their poison fangs are capable of inflicting serious bites on man.

The galley worm (Spirobolus), a common species of milleped, lives under

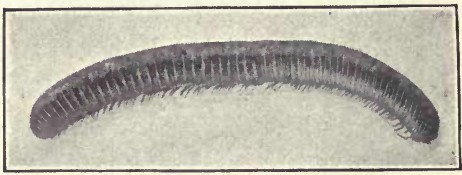

FIG. 154.-Galley worm.

stones and logs where it feeds on dead snails and earthworms. Polydesmus is a flat milleped found in moist places.

\section{CRUSTACEA}

The crustaceans differ from the other arthropods in usually breathing by gills and having two pairs of antenn:e. Many forms possess a hard outer skin or exoskeleton to which the name of the class is due. The fresh water crayfish (Cambarus) and the lobster (Homarus) are so similar in structure that a description of one applies almost equally well to the other.

The body of the crayfish, bearing nineteen pairs of appendages, is divided into a cephalothorax and abdomen. The former, including the head and thorax, is covered by a calcareous shield, the carapace, which when broken off on the sides reveals the gills composed of feathery filaments with 


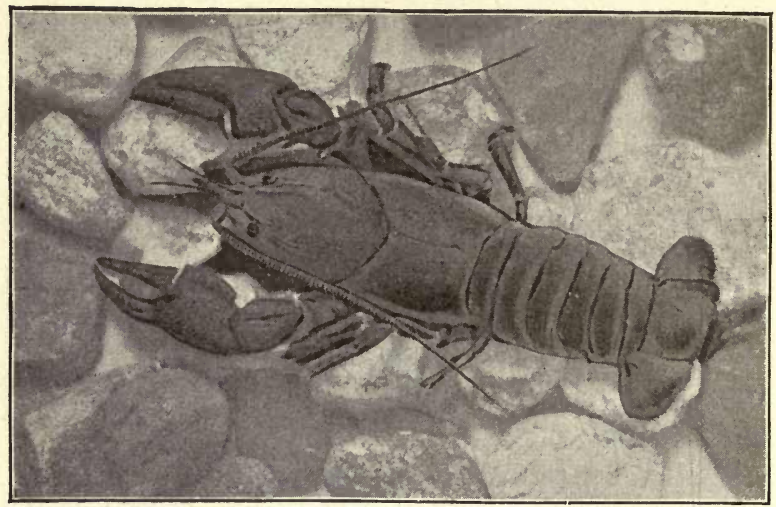

FiG. 155. - Crayfish or crawfish (Cambarus bartoni). Photograph natural size. The antennæ are the two long backward projections from the head and the antennules the short forward projections.

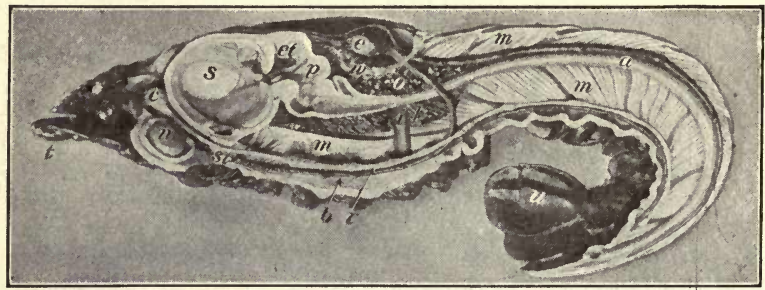

FIG. 156. - Crayfish with the left half of the body structures removed; $a$, intestine ; $b$, ventral artery ; $c$, brain; $e$, heart ; et, gastric teeth ; $i$, oviduct ; $l$, liver ; $m$, muscles ; $n$, green gland (kidney) ; $o$, ovary : $p$, pyloric stomach; $r$, nerve cords; $s$, cardiac stomach ; $s t$, mouth ; $u$, telson; $w$, openings of veins into the pericardial sinus. Twice natural size.

the bases of the main stems attached below. A median spine, the rostrum, projects between the eyestalks supporting the compound eyes on movable stalks, beneath which 
are the antennules about one fourth as long as the jointed antennæ proper. On the lower surface of the basal joint of each of these is the opening of the green glands or kidneys. On the thorax are four pairs of long slender walking legs, in front of which is a pair of very large legs called chelipeds, terminating in pincers, the chelo. Anterior to these are three pairs of small appendages, the maxillipeds, or jaw feet, of use in feeding.

The head proper shows in the mouth region a pair of hard notched lateral moving mandibles and behind them two pairs of leaflike maxillox. The second pair of maxillæ differs from the first pair in having a flat paddle-like process, called gill bailer, used to bring the water forward from the gill chamber, in which are the gills beneath the carapace. On the ventral side of several segments of the abdomen are small appendages, termed pleopods or swimmerets, which carry the eggs in the female. Each pleopod consists of a basal piece, the protopodite, and two branches, the outer of which is the exopodite and the inner the endopodite. This is the typical structure of a crustacean appendage, but in many cases it is much modified by use, as in the walking legs where the exopodite is wanting.

By pinning down the specimen in a waxed-bottom pan full of water and cutting off the carapace and dorsal portion of the abdomen, some of the structures shown in the figure may be found. The male can be distinguished from the female by the presence of the minute orifice of the reproductive organ on the ventral side of the last leg near its junction with the thorax. In the female the opening is on the third leg from the last. 
The blood of the crayfish, like that of the insects, is colorless. After circulating through the arteries and their branches to carry oxygen and nourishment to all parts of the body it collects in irregular channels, called sinuses, lying between the muscles and the other organs. From the sinuses, vessels lead the blood to the gills on either side beneath the carapace to absorb oxygen from the surrounding water and give off the carbon dioxide collected from the tissues of the body. From the gills the blood returns

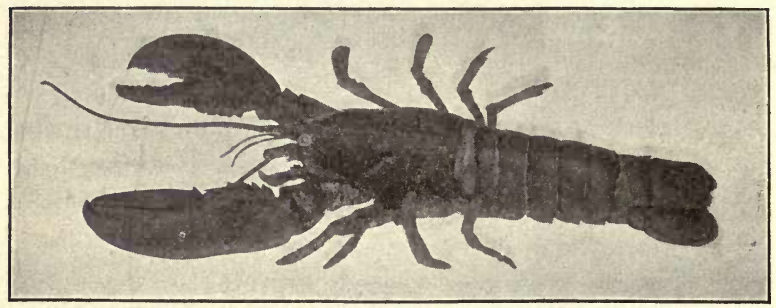

Fig. 157. - Photograph of the lobster one third natural size.

to the pericardial sinus and enters the heart through six slits with valves opening inward.

The lobster (Homarus americanus) ranges along the Atlantic coast from Labrador to Delaware Bay. Of late years it has become so scarce that laws have been passed for its protection. In Connecticut none may be caught under six inches long, while in New York and Massachusetts they must be not less than ten and a half inches in length. At Cold Spring Harbor, Long Island, and at Woods Hole, stations have been established by the government for the purpose of rearing young lobsters. The eggs, 
numbering several thousands, are taken from the female which carries them entangled among the pleopods on the ventral side of the abdomen, and hatched in prepared tanks. The young are thus protected from the voracious appetites of marine fish, and when old enough to care for

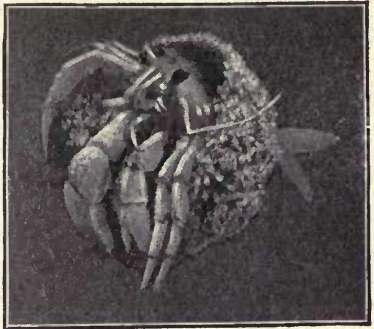

FIG. 158. - Hermit crab (Eupagurus longicarpus). Natural size. themselves are distributed at favorable points along the coast.

A molting process takes place among the crustaceans

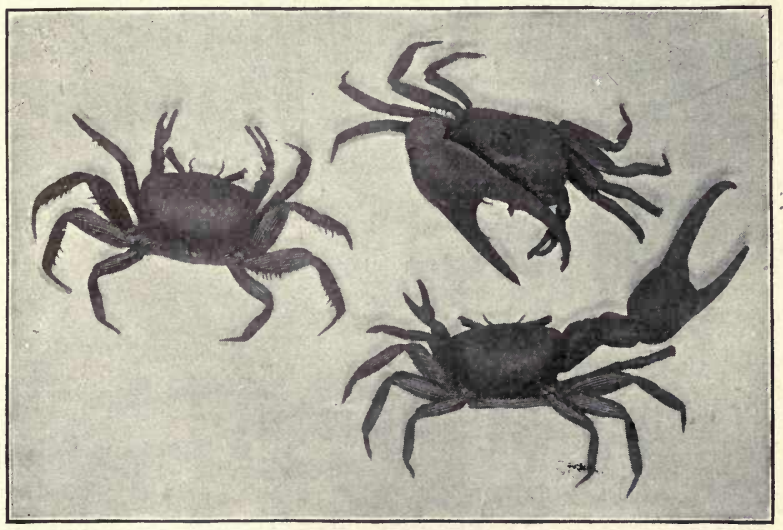

FIG. 159. - Fiddler crabs (Celasimus minax). Note the large fighting chela on the two specimens at the right. On specimen at left it was broken off and is just being renewed. Photograph natural size by Overton. 
similar to that occurring in the larvæ of insects. The hard covering becomes too small for the growing animal, and in the lobster it splits along the median dorsal line, while the blood leaves the limbs, permitting them to be withdrawn from their casements. The lining of the whole alimentary canal is also shed. The animal just before molting is known as the black lobster. The newly molted crab is marketed under the name of soft-shelled crab.

The hermit crabs protect themselves by living in the abandoned shells of some mollusks, and when the increased size of the

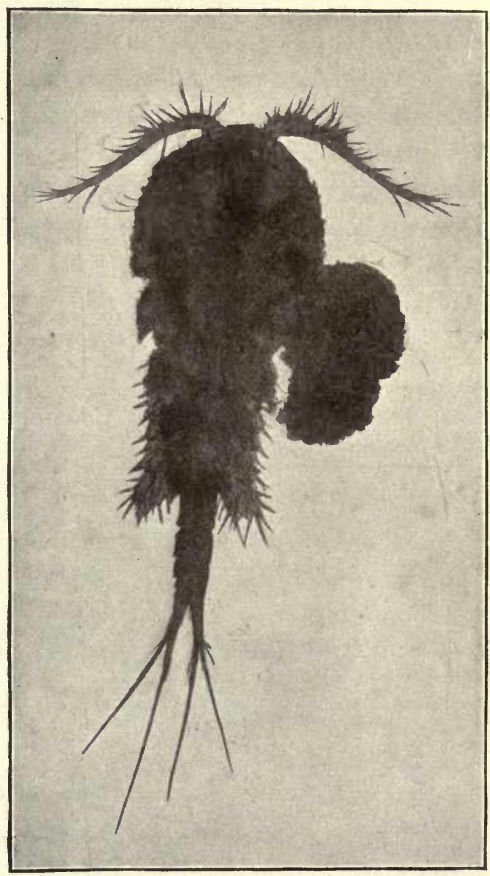

FiG. 160. - Photograph of Cyclops enlarged forty times. An egg mass at the right: body makes the shell too small, the animal seeks a larger one. Of the edible crabs, the commonest are the large blue crab (Callinectes hastatus), and the oyster 
crab. (Pinnotheres ostreum) the female of which lives in oysters.

The water fleas just visible to the naked eye are present in nearly all waters and become very abundant in stagnant water. The common fresh watergenera are Cypris, Daphnia, and Cyclops. They make up a large part

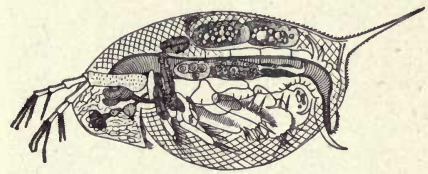

FIG. 161.-Daphnia enlarged forty times. of the food for young fish. Many species of small crustaceans are parasites on fish or other aquatic animals, and because of their habits become so changed in ap-

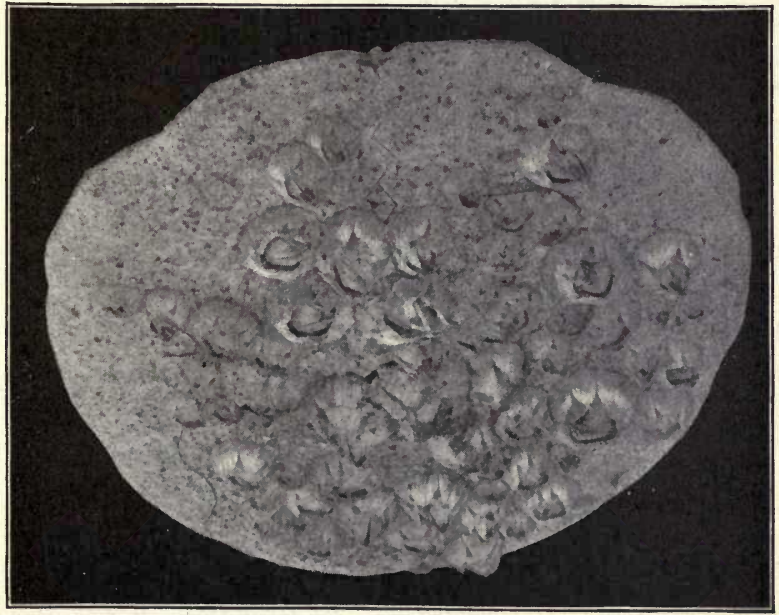

FIG 162. - Acorn-shell barnacles on a sand dollar. 
pearance as to lack all features characteristic of the class.

The barnacles found only in salt water show how organs

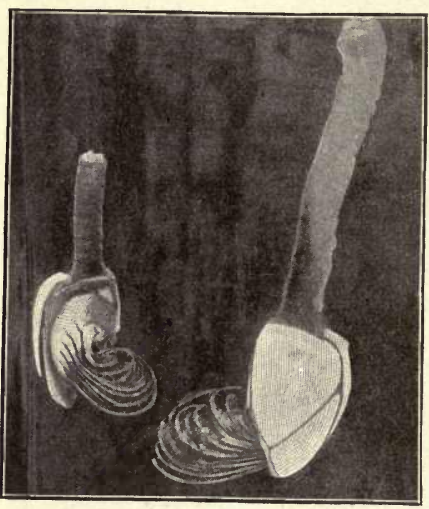

FIG. 163. - Goose barnacles with the right shell removed from the one on the left. Natural size. originally intended for one purpose may be adapted to another. The acorn-shell barnacle (Balanus balunoides) lives in calcareous shells attached to the bottoms of ships, wharves, or other objects in the water. The legs no longer needed for locomotion, as in its ancestors, are extended through the open shell to secure food. On account of disuse the eyes have been lost. The goosebarnacle (Lepas anatifera) is often found attached to floating objects by a stem two or three inches in length. Between the two pairs of calcareous plates protecting the body are thrust appendages, formerly used as legs, to catch food.

The terrestrial crustaceans number but a few species. The common ones known as pill bugs,

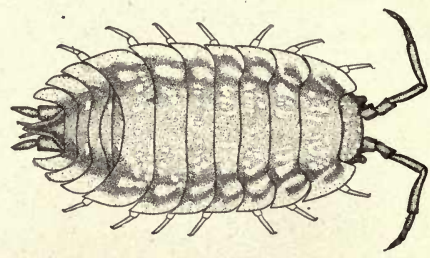

F1G. 164.-Sow bug (Oniscus asellus). After Paulmier. 
sow bugs, or wood lice abound everywhere under logs and stones during most of the year. They are about a half inch long and have a convex grayish dorsal surface. They feed on decaying vegetable matter. Respiration is effected by gills instead of by lungs or tracheæ characteristic of most land forms. The inner terminal divisions of the abdominal legs, which are covered and kept moist by the outer division, are the gills.

Crustaceans are remarkable for their perfect adaptation to widely different conditions of life. They dwell in fresh water, in the sea, on land, and as parasites. In the Mammoth Cave of Kentucky are blind crayfish which

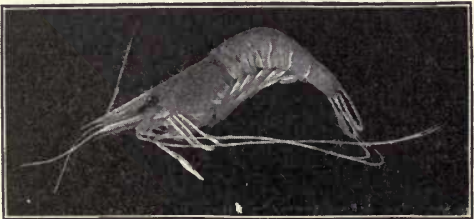

Fig. 165. - Photograph of the shrimp. Natural size.

show by certain features that they are undoubtedly descended from the forms outside of the cave enjoying perfect sight. Some species live in the ocean at a depth of nearly four miles. While most crustaceans are solitary, some like the shrimp much used for food occur in vast shoals in the ocean. 


\section{PART II}

\section{THE ANARTHROPODA: INVERTEBRATES WITHOUT JOINTED LEGS}

\section{Io. MOLLUSCA}

THE members of this phylum differ from the preceding in not having segmented bodies or jointed feet. Most of the twenty thousand species are included in the three important classes, - Pelecypoda, Gastropoda, and Cephalopoda.

\section{Pelecypoda: Bivalved Shellfish}

The name bivalve is derived from the two shells which hinged together form the protecting case for the softbodied animal within. All bivalves are aquatic. Certain species form a leading item of food in many parts of the world.

The soft-shelled clam (Mya arenaria), abundant north of Cape Cod, occurs in large numbers in the mud flats, from which they are dug at low tide. They usually lie in the mud at a depth of from two inches to a foot, and have a very long siphon consisting of two tubes, of which the ventral one is used for taking in water and food, while the excretory products pass out through the dorsal one.

The hard-shelled clam (Venus mercenaria), or quahog, is the common edible species south of Cape Cod. 
The fresh water clams, Anodonta and Unio, often called mussels, are present in large numbers in some fresh water streams and lakes. The shell of the Unio is smaller and thinner than that of Anodonta. The sexes are separate, but the male resembles the female so closely that a microscopic examination of the reproductive glands is necessary to distinguish one from the other.

The eggs of clams are hatched within

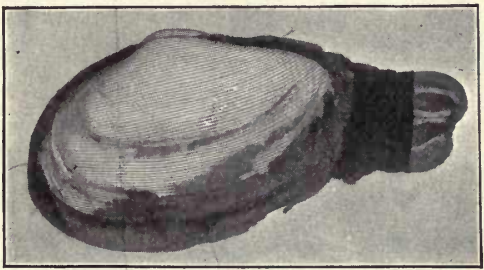

Frg. 160. - Soft-shelled elam with a piece cut out of the end of the siphon to show both tubes. Photograph natural size.

the shell of the mother, and in a few months the young pass out into the water and attach themselves to fishes by a pair of sharp projections on the ventral margins of the shell. Here they lead a parasitic life, absorbing juices from the body of the fish for some weeks and pass through a metamorphosis, after which they drop to the bottom and feed on small crustaceans and other aquatic organisms. Most

clams move about from time

FIG. 167. - Hard-shelled clam. Photograph half natural size. to time by means of a single ventral projection, the foot, which is protruded between the open valves.

The oyster (Ostrea virginiana), so highly prized for food, 
differs from the clams in having no siphon and a foot se rudimentary as to be unable to move. The oystermen are therefore accustomed to plant the young in shallow water where they remain three or four years to mature. Our

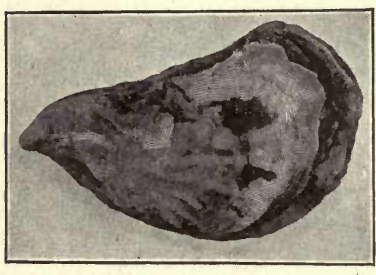

FIG. 168. - Oyster of the Atlantic coast

(Ostrea virginiana). Photograph one half natural size.

Atlantic coast furnishes twenty-five millions of dollars' worth of oysters annually. The Japan oysters are the largest, some species attaining a length of three feet.

The pearl oysters (Meleagrina), along the Persian Gulf and coasts of Ceylon, are the source of most pearls, but some pearls have been found in the fresh water clams and oysters of our own country. Pearls are deposits of nacre formed around foreign bodies by the inantle, and are of the same composition as the inner lining of the shell so much valued as the mother of pearl. The ship-

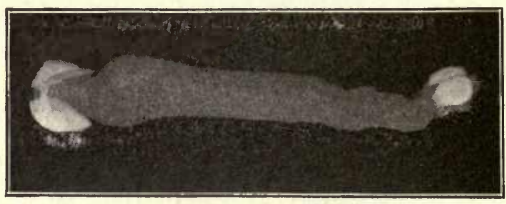

worm (Teredo Fir. 169. - Photograph of the shipworm slightly ennavalis) is a pecularged.

liar bivalve, causing much damage by boring into ships and piles supporting the wharves along the ocean.

Anatomy of the Fresh Water Mussel. - Any clam may be used for dissection, but the following description applies 
particularly to the fresh water mussel. A horny or elastic ligament unites the two valves on the dorsal aspect and tends to open the shell along the ventral margin. The concentric parallel ridges on the outside of the shell represent successive additions of lime and are called lines of growth. The elevation near the hinge is the umbo. To open the shell place it in boiling water a minute or two and then slip the knife between the two slightly open valves and loosen the adductor muscles from one side of the shell. The line within the valve concentric with the ventral margin and connecting the two muscle

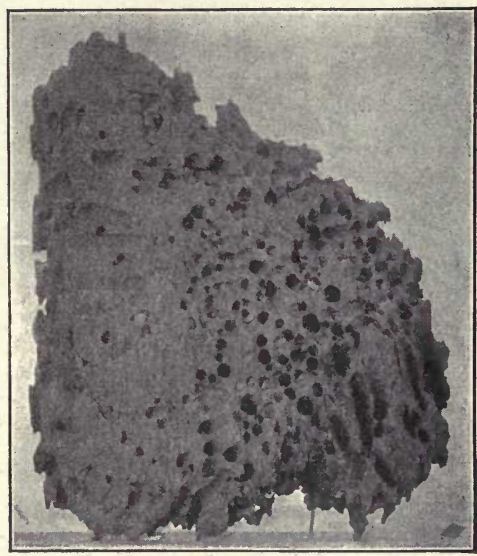

Frg. 170. - Wood injured by the shipworm.

scars is the pallial line along which a membrane, the mantle, is attached. The two mantles covering the body of the mussel are almost as large as the valves to which they adhere closely. By removing the left mantle and immersing the specimen in a pan of water the relations of the soft parts may be made out. The firm conical mass projecting ventral and anteriorly is the foot. The gills are the two thin membranes on either side of the body just within the mantle. They are covered with ciliated cells, whose pur- 


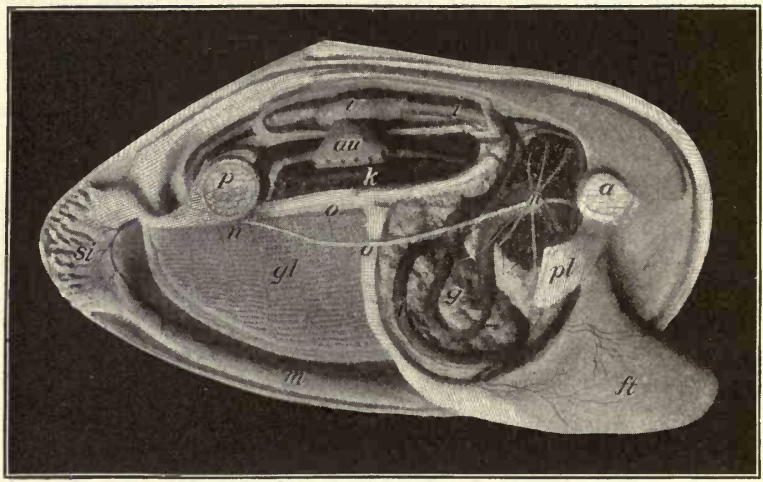

FIG. 171. - A fresh water mussel with the right valve mantle and gills and some tissue at the base of the foot removed; $a$, anterior adductor muscle; $a u$, auricle of the heart ; $f t$, foot ; $g$, reproductive gland ; $g l$, gill ; $i$, intestine ; $k$, kidney ; $m$, mantle; $n$, nerve ganglia connected by nerve cords $o ; p$, posterior adductor; $p l$, labial palps; $s i$, siphon; $v$, ventricle. The dark lines on the mantle and foot are blood vessels.

pose it is to cause the water to flow in and out through the siphons, thereby bringing in food and oxygen. By detaching a minute portion of the gill of a live mussel and mounting it in a drop of water on a glass slip and examining with the microscope the cilia (hairlike processes) may be seen in motion.

The heart, consisting of two auricles and a ventricle, is seen by removing the dorsal portion of the mantle. In a live mussel opened, the heart can be noticed beating, as the milky blood passes from the auricles to the ventricle and thence through the pedal artery to the foot and body. It then goes to the gills where carbon dioxide is given off and oxygen received before it is returned to the heart. 
The digestive system is well defined. Near the anterior adductor muscle between the two pairs of triangular flaps, called labial palps, is the mouth opening into a short esophagus leading into the stomach surrounded by a dark tender mass of tissue, the liver, from which ducts empty into the stomach. The intestine after leaving the stomach makes a turn on itself in addition to several bends, and terminates dorsal of the posterior adductor muscle in the exhalant siphon.

The nervous system is difficult to demonstrate. It consists of three pairs of ganglia or bunches of nerve cells connected by nerve cords. The visceral ganglia lie on the under side of the posterior adductor muscle. From these a pair of threadlike nerves extend forward to the cerebral ganglia at the base of the labial palps and behind the anterior adductor muscle. A circular nerve cord joining these two ganglia surrounds the mouth and from each a nerve cord leads to the pedal ganglion near the center of the foot.

\section{Gastropoda: Snails and Slugs}

The univalve mollusks are unsymmetrical and have but one shell which is often in the form of a spiral. The pond snail (Limnea), abundant in ditches and stagnant ponds, has a right-handed shell, i.e., starting from the apex the coil turns toward the right. Physa, the other pond snail, has a left-handed shell. The eggs of pond snails appear as minute white spots in a mass of transparent albumen. During the summer months they are easily found adhering to boards, stones, and other objects in the quiet waters. 

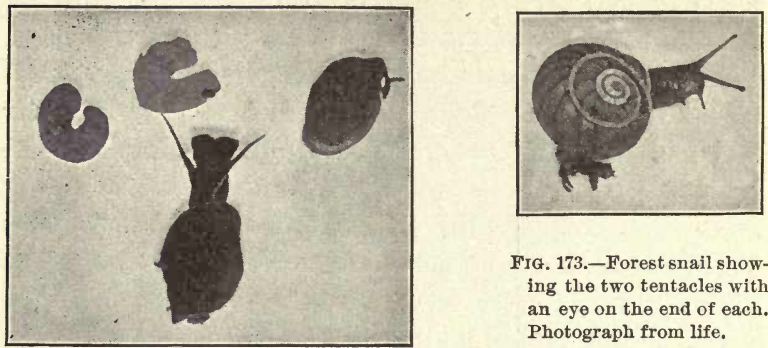

Fig. 173.-Forest snail showing the two tentacles with an eye on the end of each. Photograph from life.

FIG. 172.--Pond snail and two of its egg masses. The one on the right is entirely withdrawn in its shell. Photograph from life natural size.

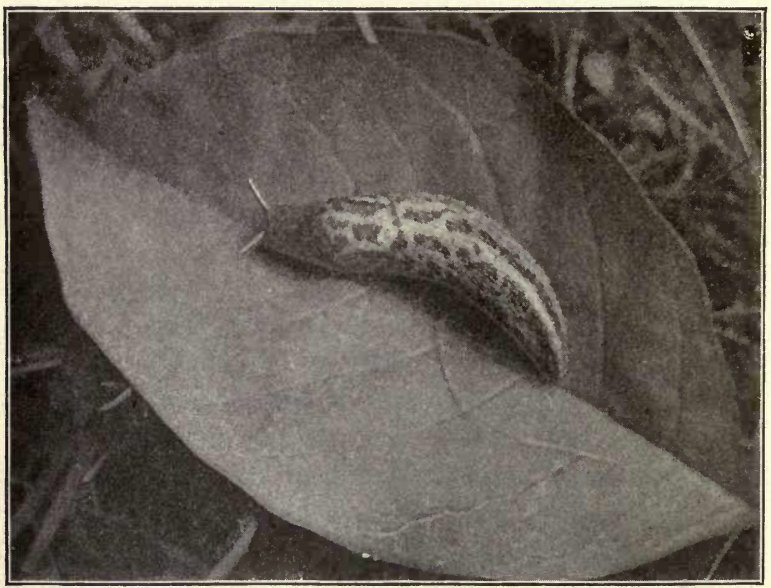

FiG. 174. - Photograph of the big slug one half natural size. 
Examination of the young while still in the egg mass will show the beating of the heart.

Planorbis, another aquatic snail, is distinguished by having all its whorls in the same plane. The forest snail (Helix albolabris) and the big slug (Limax maximus) are terrestrial. The slugs are characterized by the absence of an external shell and in its stead a plate-like shell buried in the mantle on the back. Slugs and snails breathe by means of lungs, the opening to which is a round hole at the edge of the mantle. Slugs are destructive to garden plants, a common offender being the small dark brown one hiding by day under boards and logs.

Cephalopoda: Squids, Cuttlefish, etc。

The members of this class are so named because a portion of the foot is fused with the head. Around the mouth are several tentacles or arms provided with suckers, serving as powerful organs in seizing prey. In the common squid (Loligo pealii), the lower portion of the foot forms a tube through which the water contained in the mantle cavity may be violently expelled and the animal thus propelled through the water. Into this funnel opens the duct of the.

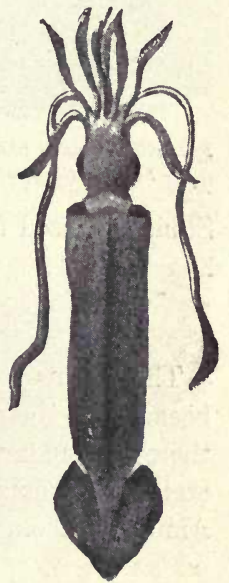

FIG. 175. - The squid. One fourth natural size. ink sac by which the squid and cuttlefish color the water in order to escape from their enemies. The sense of sight is well developed in the cephalopods, a large eye being 
located on either side of the head. In the squids and cuttlefish the shell is rudimentary and is buried within the mantle, while in the pearly nautilus (Nautilus pompilius) it is in the form of a spiral divided into chambers, the largest and outer of which is alone occupied by the animal.

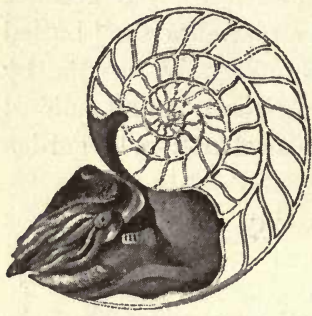

FIG. 176. - Pearly nautilus with half the shell removed. As soon as the body becomes too small for one chamber it moves forward, constructing a partition behind it. This is the creature which inspired the celebrated poem, "The Chambered Nautilus," by Holmes.

The cephalopods are of little economic importance. The cuttlefish supply sepia for the artist and are of some use for food. Squid are used for cod bait along the New England shore.

\section{VERMES}

The worms form a group of animals not easily defined because of their great variation in structure and habits; therefore modern zoölogists have separated them into several subkingdoms, of which the three most important are Annulata, Nemathelminthes, and Platyhelminthes.

\section{Annulata or Segmented Worms}

This phylum is widely represented by leeches and earthworms. As the habits of the two groups are quite different, each will be described separately.

Leeches. - These are often called bloodsuckers, owing to 
their habit of fastening themselves to the skin of man or any of the lower animals and sucking their blood. They are usually found in moist places only, often being aquatic.

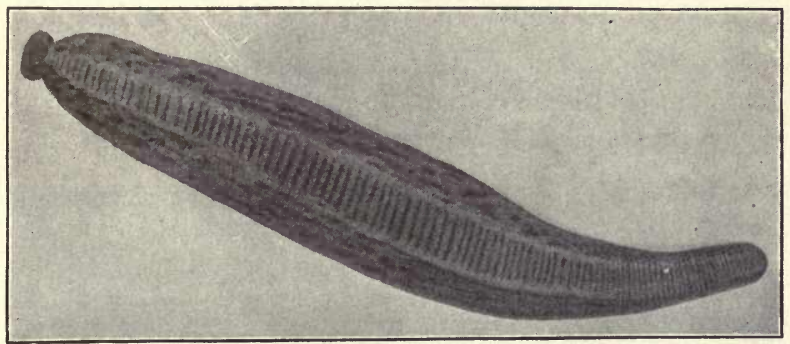

FIG. 177.- Photograph of the medicinal leech. Natural size.

The medicinal leech (Hirudo medicinalis) was used fifty years ago for blood-letting when the fallacious idea pre-

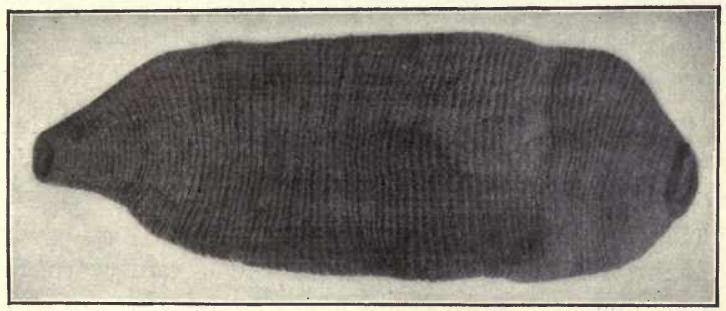

FIG. 178. - The large water leech just after a full meal. Ventral view showing both suckers, head at the left. Photograph natural size.

vailed that people could be cured of sickness by letting out the bad blood. After the leech fastens itself to the skin by its suckers the toothed jaws quickly rasp a hole 
through to the superficial blood vessels and in an hour the hungry creature will be distended to triple its former size. The alimentary canal has several pouches along either side to increase its capacity. A full meal lasts the animal one year.

In some parts of the tropics such as India and Ceylon, there are land leeches about an inch long in the meadows and wonds capable of scenting their prey at some distance,

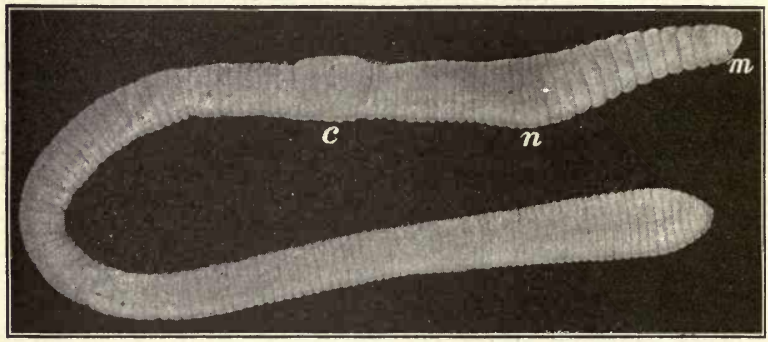

FrG. 179.-Night walker ; $c$, clitellum ; $m$, mouth ; $n$, opening of reproductive glands. Photograph natural size.

and are quick in their movements, so that a person brushing through the jungle often becomes covered with theni. The largest leech is an American species, Macrobdella valdiviana, which attains a length of more than two feet.

Earthworms. - These are often called rain worms or angleworms. There are a dozen or more species in this country, but for study the night walker (Lumbricus agricola) is best on account of its large size. It may be recognized by its flattened posterior end. It lives in rich garden soil and near manure piles. In dry weather the holes may extend to a depth of six feet. Specimens may often be 
caught by seeking them with a lantern at night when they roam about. They can easily be kept for months in a box of rich earth occasionally moistened and supplied with decaying leaves. A wire netting should be tacked over the top. In order to kill them properly for dissection, they should be placed in a jar or dish a foot in diameter and covered with water to which thirty cubic centimeters (one ounce) of alcohol is to be added every forty or fifty minutes

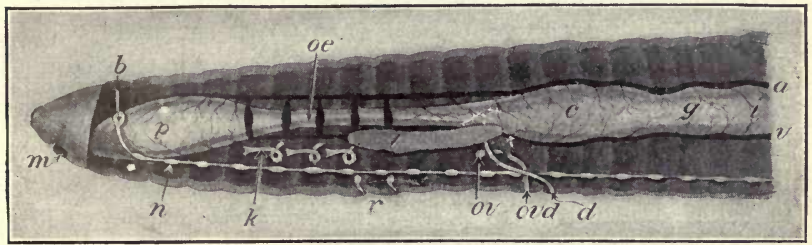

FrG. 180. - Forepart of an earthworm with the left body-wall removed; $a$, dorsal blood vessel ; $b$, brain ; $c$, erop ; $d$, opening of the male reproductive organs; $g$, gizzard ; $i$, intestine; $k$, kidney ; $m$, mouth; $n$, one of the ganglia of the nerve cord ; oe, esophagus; p, pharynx; $r$, receptacles for sperm cells ; ov, ovary ; ovd, duct from ovary; $v$, ventral blood vessel. Drawing by W. H. Reese.

until they becorne unconscious. They are then best preserved in seventy per cent alcohol.

Each of the segments or somites numbering about one hundred and fifty bears four pairs of short bristles (setæ) by means of which the worm holds itself so firmly in the burrow when one attempts to dislodge it. The swollen band between the thirtieth and forticth somites is the clitellum, from which exudes a sticky substance used to construct the egg band. This encircling band after being hardened by the air is worked forward and as it passes the fourteenth or fifteenth segments receives the eggs there extruded by two minute apertures not visible to the naked. 
eye. Between the ninth and eleventh somites are two pairs of openings from which sperm cells enter the band and render the several eggs fertile. As the band slips off the head it is changed into a closed capsule within which only one worm develops, the others being devoured by the sole survivor.

For dissection, a worm over five inches long should be pinned ventral side down in a pan of water and a slit made with the scissors through the body wall in the anterior half along the mid-dorsal line. Pin down the body walls on either side and note the parts as shown in the figure. The blood runs forward in the dorsal vessel and backward in the ventral one. No true heart is present, but the five pairs of aortic arches are contractile. The paired nephridia in each somite are the kidneys, which conduct the waste matter outside of the body. The worm has no tracheal tubes, gills, or lungs, but receives oxygen into the blood and casts out the carbon dioxide by means of the small vessels ramifying near the surface.

Earthworms feed on decayed leaves and other vegetable matter. They are of much service in keeping the soil loose and permitting the water and air to penetrate to the roots of plants by means of their burrows. They also make good food for birds. Their power of regeneration after injury is remarkable. If one be cut in two near the middle each half will often develop into a complete worm. The power to regenerate lost parts is much greater in the lower animals than in the higher ones. A tadpole may regenerate a lost leg but not a half or even a fourth of its body, while a mammal can not reproduce even a fourth of a finger or toe removed. 


\section{Nemathelminthes or Threadworms}

The round worms differ from the Annulata in not showing any external evidence of segmentation. Most of the species live as parasites during part or all their lives. Ascaris is a genus containing several species which are often present in the intestines of mammals, and one species is common in the lungs of the frog. Trichina, a microscopic round worm causing the condition known as measly pork, is a dangerous parasite to man. He becomes infected by eating affected pork not well cooked. In 1892,

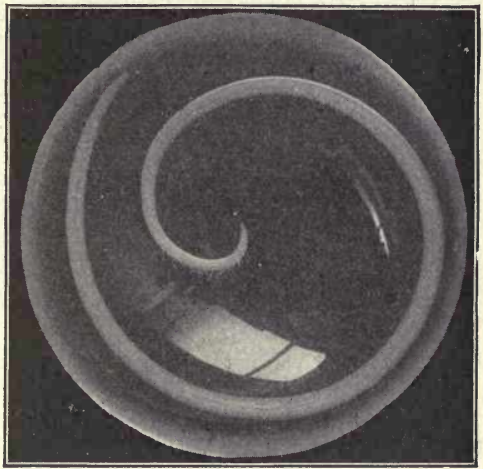

FIG. 181.- Ascaris lumbricoides : a parasite of ten present in the intestine of ehildren. Photograph natural size.

the United States Department of Agriculture found over seventeen thousand carcasses of hogs containing Trichinæ. A fuller discussion of parasitic worms is given in the chapter on parasites.

The vinegar eel (Anguillula) is a free living worm often present in good cider vinegar. It is just large enough to be recognized by the naked eye, and if a little vial containing some vinegar be looked at toward the light as many as five hundred may be seen squirming vigorously. They are 


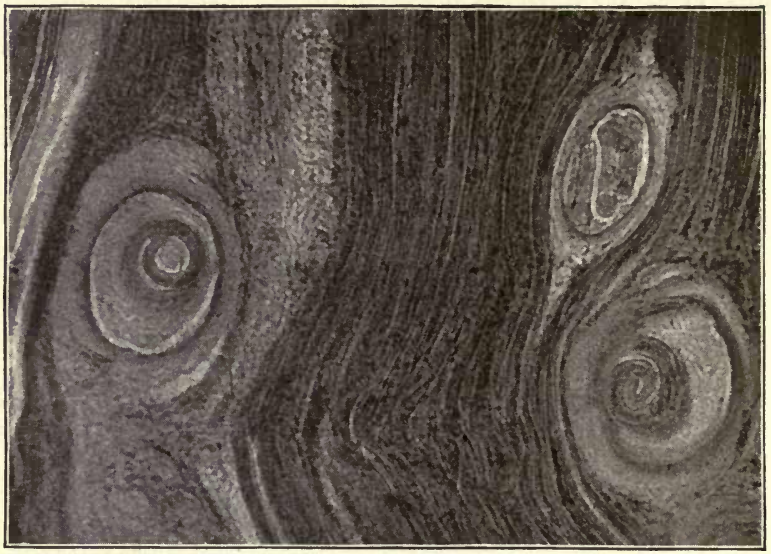

FIG. 182. - Three encysted Trichinæ in human flesh. Photograph enlarged sixty diameters.

harmless to man. A species of Anguillula is also common in stagnant ponds and ditches, and may be found by examining under the low power of the microscope a drop of water scraped from decaying wood or leaves taken from foul water.

Horse-hair worms of which Gordius aquaticus is the most common occur in streams, ponds, and watering troughs. They do not originate from a horse hair, as is popularly supposed. They are from five to ten inches long and as thick as a pin. The eggs are either laid in the damp earth or water. In the latter case the young socn after hatching bore into the larva of some aquatic insect which is later eaten by a fish. The young hair worm no larger than a 
pin head works its way through the walls of the fish's intestine to the muscles, remains several months quiescent until spring, when it again enters the intestine and passes out into the water. Its length at this time is

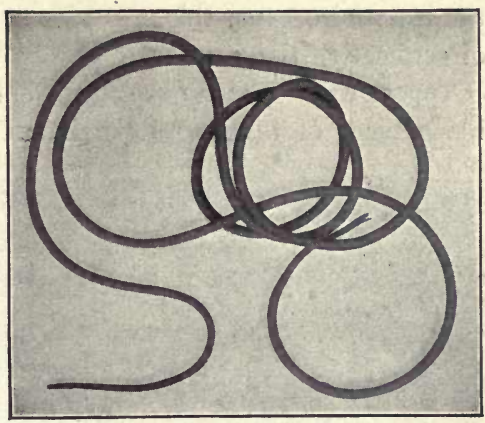

Fia. 183,-Horse-hair snake. Photograph twice natural size. about an inch.

In a few weeks it reaches full size. The young of those species laying eggs in the damp earth bore into caterpillars, grasshoppers, locusts, and beetles. During the months of August, September, and October hair worms may sometimes be found in the locusts by pulling open the abdominal cavity with forceps or needles.

\section{Platyhelminthes or Flatworms}

The flatworms are remarkable for their variation in size. Some of them living parasitic on the gills of fish and the king crab are only one or two millimeters long, while the tapeworms parasitic in man reach a length of fifty feet. Many members of this phylum are parasites and all have soft bodies usually much flattened dorsoventrally. There is no body cavity (cclome) surrounding 
the internal organs, this space being filled up with a kind of connective tissue called parenchyma.

Tapeworms. - These are so named because they resemble a piece of tape. All are parasites and dwell within

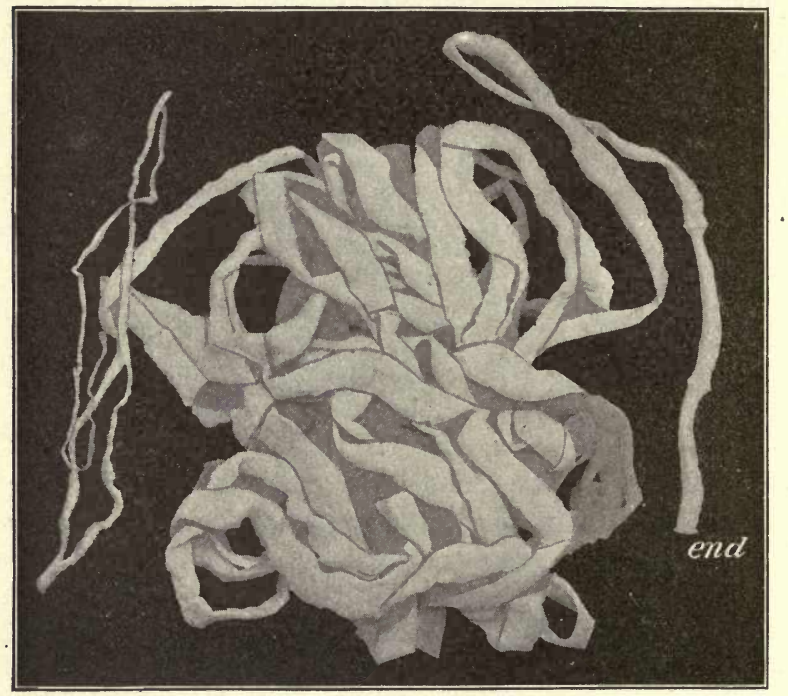

Fia. 184. - Human tapeworm fourteen feet in length; $h$, head. Photograph three fourths natural size.

various species of vertebrates from fish to man. The life history of Tania saginata, a human parasite, is typical of the group. In the adult state it dwells only in the intestine of man and is usually from ten to fifty feet in length. Its head known as the scolex is armed with four 
suckers enabling it to hold fast in the mucous coat of the canal, while its body, called strobila, lies free in the intestine. The segments of the body, narrow and short near the head, increase in size posteriorly and may number as many as one thousand. They are known as proglottides. It has no alimentary canal and no blood system, the nourishment being absorbed through the body wall. The nervous system consists of two small ganglia in the head and a nerve cord extending from them along each side of the body. Each of the segments in the posterior half of the adult worm contains both male and female organs of reproduction and each segment near the end has more than a thousand mature eggs. From time to time a segment is broken off and passes to the exterior where if through water or otherwise the eggs within it reach the alimentary canal of the cow further develop-

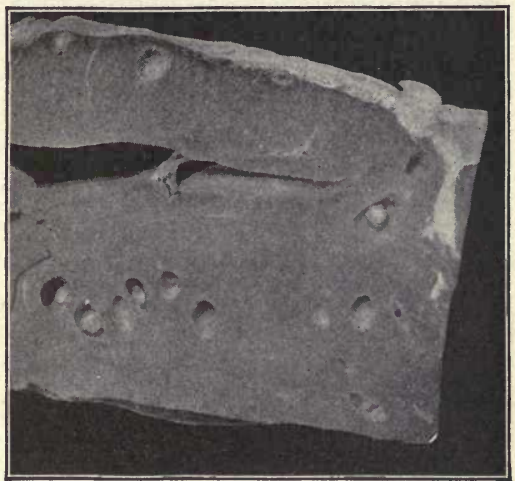

FIG. 185.-A piece of pork containing several cysticerci (larvæ) of a human tapeworm (Trenia solium). Photograph natural size. ment ensues.

The young migrate from the digestive tract of the cow to the muscles and form a cyst or sac in which stage it is known as a bladder worm or cysticercus. This is the larval 
state, and no further growth occurs until the meat is eaten by man in whom the larva transforms into the tape form. The poisonous excretions given off by the worm cause nausea, headache, and dizziness in the host.

The larval stage of the tapeworm of the dog is found in the rabbit, while the early stage of the cat's tapeworm occurs in the mouse. It is therefore evident that the completion of the life cycle in these parasites requires two hosts.

Fresh Water Flatworms. - These are common in most ponds and streams. They vary in size from minute

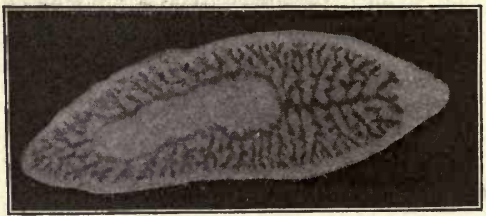

FIG. 186. - Planaria; a common aquatic flatworm.

The two minute dots in the head are the eyes, and the black much branched structure is the alimentary canal. Photograph enlarged four diameters. specks to forms more than a half inch in length. The whitish or grayish color together with their slowgliding movements over the surface of water plants and the under sides of stones and sticks are the features by which they may be recognized. They move largely by means of the cilia over the surface. A good plan for securing them is to place in a jar of water some sticks and leaves taken from several quiet pools. The following day they may be seen on the side of the vessel. In many forms the mouth is in the middle of the under side and the alimentary canal has a forward and two backward extensions with numerous lateral branches. This group has the power of regeneration to such a degree that if an individual 
be cut into several pieces each one will grow into a complete worm.

The largest of the flatworms are marine and belong to the group Nemertini. Some of these reach a length of nearly one hundred feet. The common form found along the Atlantic coast is Cerebratulus, which has a flat, creamcolored body two or three feet long. It inhabits the mud and sand at the water's edge where it may be dug out during low tide.

The Rotifers are interesting microscopic worms present in stagnant water. They belong to the subkingdom of Trochelminthes. Upon the head are two circles of cilia so vibrating to draw in food as to resemble the rotation of a wheel. In early summer they are parthenogenetic, i.e., young are produced from eggs which have not been made fertile by the entrance into them of the sperms (reproductive cells of the male).

\section{I2. ECHINODERMATA}

This phylum derives its name from the rough or spiny skin common to many of the species, such as the starfish and the sea urchins. All of the members of this group dwell in salt water.

The Starfish (Asterias vulgaris). - Of the several species of starfish living at depths of from one to three hundred feet, the larger forms should be chosen for study. They are numerous in the vicinity of oyster beds as they prey on these shellfish, causing great loss to the oyster industry. The normal starfish has five arms of equal length, but 
specimens are often found with as few as one or two arms full length and the others appearing as mere buds. This is due to the fact that the arms have been broken off and are just beginning to grow. If all five arms are cut off they will be reproduced. The skeleton of the animal con-

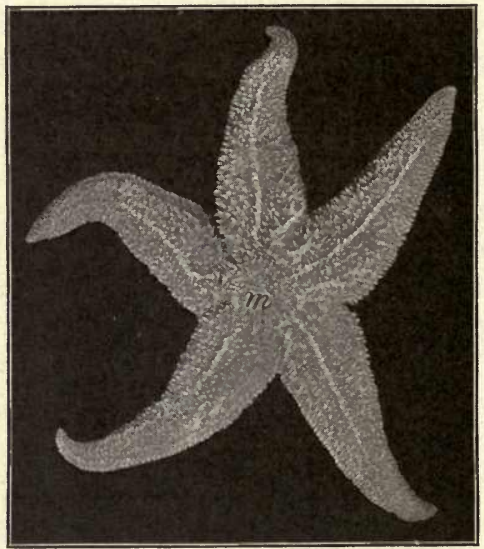

FrG. 187.-Dorsal or top surface of the starfish ; $m$, madreporic plate. Photograph half natural size.

sists of flat, irregular calcareous plates imbedded edge to edge in a leathery skin containing numerous pores through which fingerlike processes project and function as gills. The madreporic plate forms a sieve through which the water passes into the stone canal leading down to the ambulacral or water-vascular system. The latter consists of a vessel encircling the mouth and sending a branch into each arm to connect with the feet. The numerous feet are visible 
in the five ambulacral grooves on the ventral sides of the arms. The mouth is the circular opening in the center of the ventral surface.

To study the internal organs place the specimen in a pan of water deep enough to cover it, and with the scissors

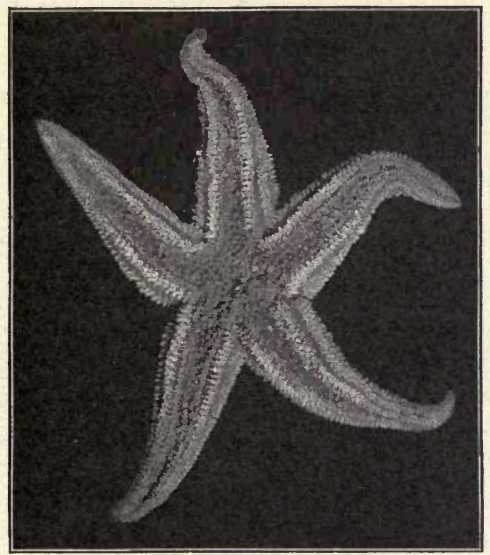

FIG. 188. - Ventral or under surface of the starfish. Black eircle in the middle is the mouth from which radiate the five ambulacral grooves, each flled with about a hundred feet. Photograph half natural size.

remove the skin from nearly half the dorsal surface cutting alongside the madreporic plate remaining in place. The saclike stomach occupies the body just beneath the skin and from it bifurcated processes, the pyloric caeca, extend more than half way to the ends of the arms. By slightly raising the skin bearing the madreporic plate, the slender stone canal may be seen leading to the ring around the 


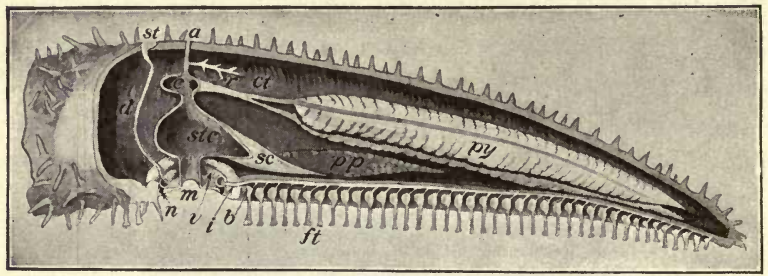

FIG. 189. - Vertical section of one arm of a starfish; $a$, anus; $b$, ampulla ; $c$, cardiac stomach ; $c t$, connection of pyloric cæca with stomach; $d$, stone canal ; $i$, radial ambulacral vessel ; $f t$, feet ; $m$, mouth ; $n$, cut end of nerve ring surrounding the mouth; $p y$, pyloric cæca ; $r$, respiratory organ ; $r p$, ovary; $s t$, madreporic plate; stc, stomach.

mouth. The removal of the pyloric cæca makes visible along the floor of the arm two rows of little bladders,

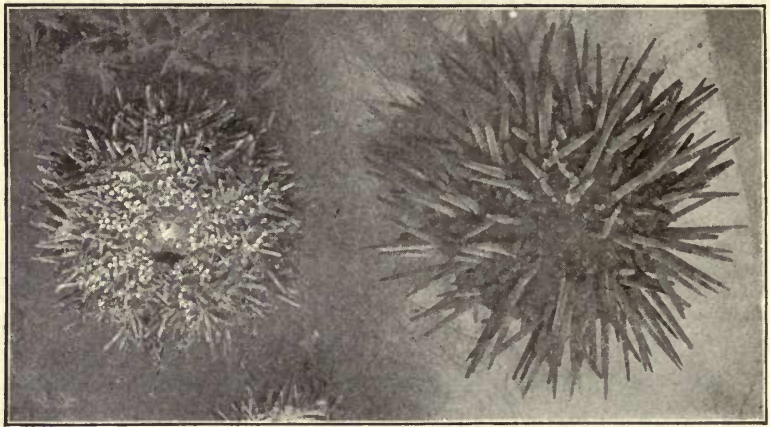

FIG. 190. - Strongylocentrotus: the green urchin on the left, and Arbacia the black urchin on the right. The green urchin seen from the ventral side shows white teeth filling the mouth and numerous feet among the spines. Photograph half natural size.

ampullo, which are usually in a collapsed condition. These receive the water from the radial ambulacral vessel extend- 
ing through each arm, and discharge it into the feet by means of which they are extended, then sucked fast to an object, and contracted to pull the animal along. The starfish has no heart, but a circular blood vessel surrounds the mouth and gives off a branch to each arm.

The nervous system consists of a ring around the mouth and five radial nerves supplying the arms. This system

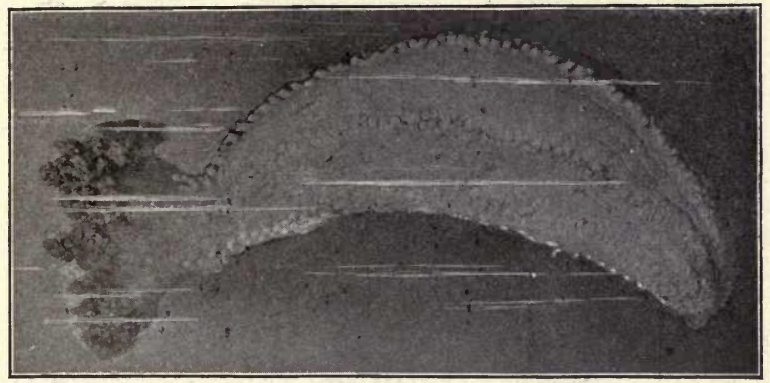

FIG. 191. - Sea cucumber (Pentacta frondosa). Photograph natural size.

is easily seen on the ventral surface by separating the two rows of feet in each ambulacral groove. The male can be distinguished from the female only by a microscopic examination of the reproductive glands, of which there are five pairs lying at the junction of the arms with the body. Each gland with its tip toward the point of the arm may be a half inch long, or if ripe two or three inches long.

Arbacia of dark color and Strongylocentrotus of a greenish hue are common representatives of the sea urchins (Echinoida) which are characterized by the presence of 
pronounced spines and usually a globular or disk-shaped body without arms. The true urchins are common along muddy coasts, and the sand dollars flat and with short, weak spines are most prevalent along sandy shores.

The sea cucumbers (Holothuroidea) have elongated cylin-

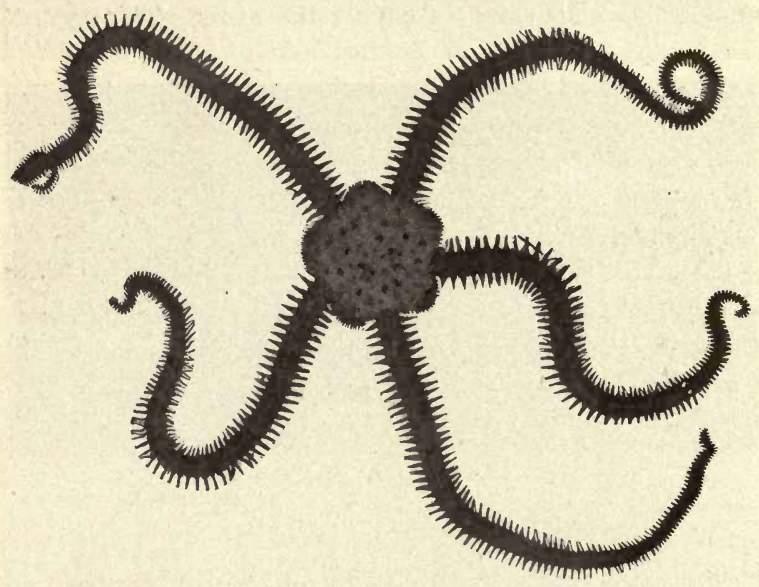

FrG. 192. - A brittle star (Ophiopholis bellis). Photograph natural size.

drical bodies with a circle of branched tentacles about the mouth, and from it five rows of feet extend posteriorly. They are found in the mud at the water's edge during low tide.

The brittle stars (Ophiuroidea) have five arms much more slender than those of the starfish and no ambulacral grooves are present. The crinoids (Crinoidea) including the feather 
stars and sea lilies differ from most animals in being attached to some object by a stalk. They usually live at considerable depth in the sea. Fossil remains show that these animals were very abundant several millions of years ago in the- Silurian period. To-day but few species exist.

The Echinodermata are lower in the animal scale than most of the preceding phyla, as they have no heart and very simple nervous and excretory systems. Thesenses of sight and hearing seem to be entirely wanting, and the sense of smell is very little developed. All the species live in the same environment and present the same characteristic radiate structure.

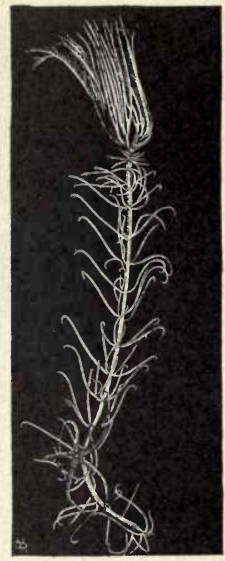

FlG. 193. - Crinoid showing the stem with which it is attached.

\section{CELENTERATA AND PORIFERA}

The two groups of animals discussed in this chapter were formerly placed in the same phylum because they are so

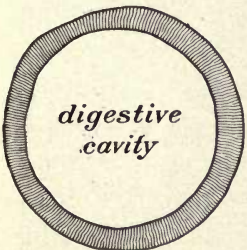

A

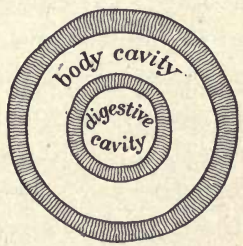

$B$

MG. 194. - Diagrammatic cross section of the body of a colenterate $A$, and that of a worm or insect $B$. much alike in habits and structure. The stinging or nettle cells possessed by the Colenterata and wanting in the Porifera separate clearly the two groups. 
Cœlenterata: Hydroids, Jellyfish, and Sea Anemones

With the exception of a few species all of the Colenterata live in salt water. They differ from most of the animals thus far described in having no body cavity (cclome) surrounding the digestive canal and in the presence of only two layers of cells in the body wall.

Hydra Viridis. - This common fresh water polyp may be found in the summer and autumn by placing in several glass jars or aquaria a considerable quantity of duck-meat or duck-weed, together with the water in which it is found growing. This plant is a favorite support for the animals. Place the jars in a north or east window and examine them daily for a week, looking through the water toward the light for a minute creature a fourth of an inch long or less with tentacles. It is usually attached to the side of the jar toward the light. When found it may be transferred with a pipette (medicine dropper) to a watch crystal for study and covered with a few drops of water.

The structure of the Hydra is that of a simple tube with walls made with two layers of cells, the outer of which is the ectoderm and the inner the endoderm. For securing food there are around the mouth several tentacles bearing stinging cells (nematocysts) containing coiled, whiplike processes which dart forth at the touch of an animal and numb it. The tentacles then slowly work the prey through the mouth into the digestive cavity where digestive juices secreted by some of the cells render parts of it absorbable by certain cells of the endoderm. The undigested portions are cast out through the mouth. Water fleas and algæ 
form much of their food. No vascular, - respiratory, or excretory systems are present, and the nervous system is represented only by a few scattered cells. Delicate

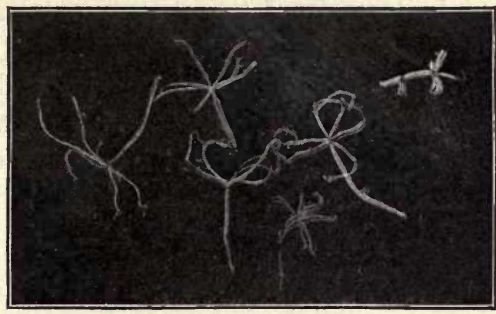

FIG. 195. - Photograph of living hydras. Each of the two at the right bears a bud. Twice natural size. muscle fibers indicate the beginning of a muscular sys-

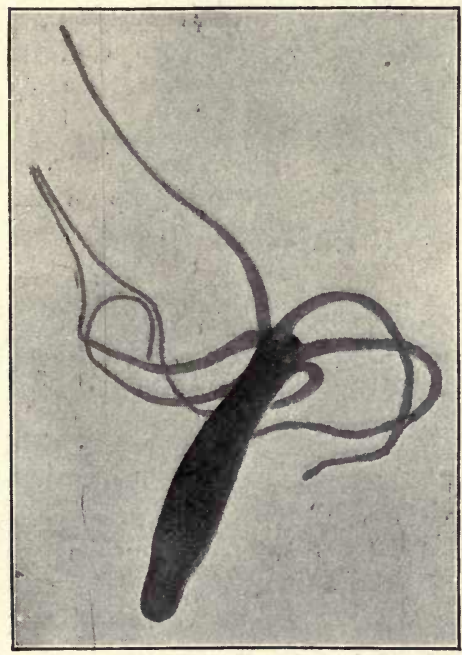

TIG. 196.-Photograph of Hydra enlarged fifteen diameters. The minute swellings on the tentacles at the left are the stinging cells. tem in the animal kingdom.

Reproduction occurs in two ways - by budding and by means of eggs. If a Hydra be watched a few minutes each day for a week, a minute bud which is really an outpushing of the wall may be seen to appear and grow larger from day to day for a period of from four to eight days until it assumes the form of the mother. It then 
breaks loose from the parent and leads an independent life.

The egg which is merely an enlarged and specialized cell near the base of the parent may develop into a complete polyp (Hydra) if one of the numerous male (sperm) cells breaking out of the spermary unites with it. Soon after

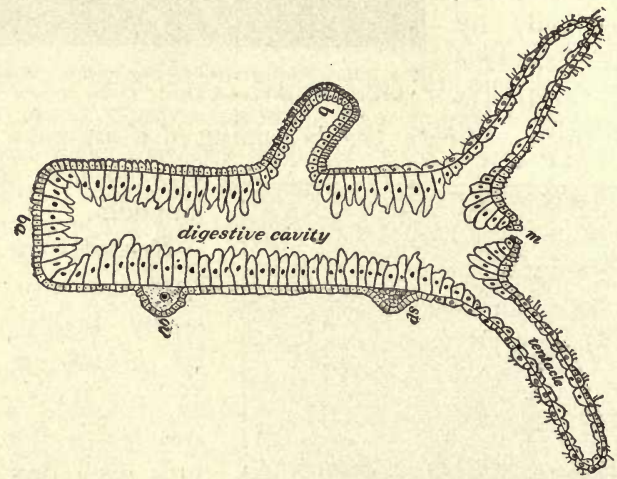

FrG. 197. - Longitudinal section of a Hydra ; $b$, bud which will form a young one; $b a$, base by which it is attached when not creeping; $m$, mouth; $o v$, ovary with an egg; sp, spermary.

the union, the egg separates from the parent and dropping to the bottom may remain there over winter before growing into a new animal.

Hydroids. - These are hydralike animals living in the ocean, and frequently growing in colonies. Obelia is a common example on our eastern coast. It is found in colonies attached to boards and seaweeds near the surface of the water. The animals composing the colony are called 


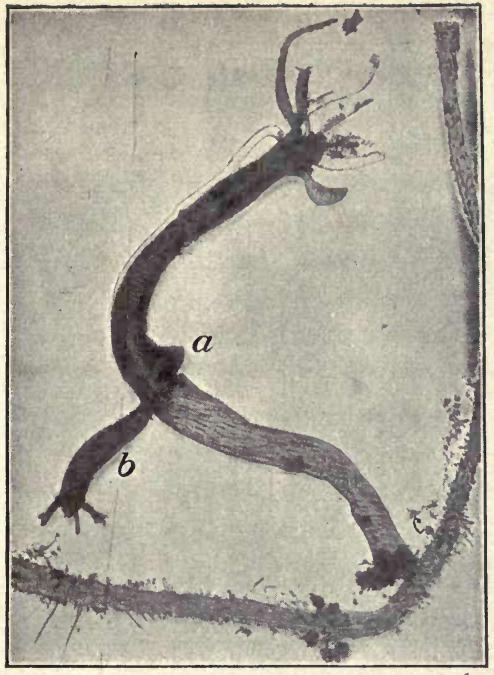

Fig. 198. - Photograph of a Hydra reproducing ; $a$, young bud about six hours old; $b$, bud four days old; $c$, base fixed to a stem. Enlarged thirty diameters.

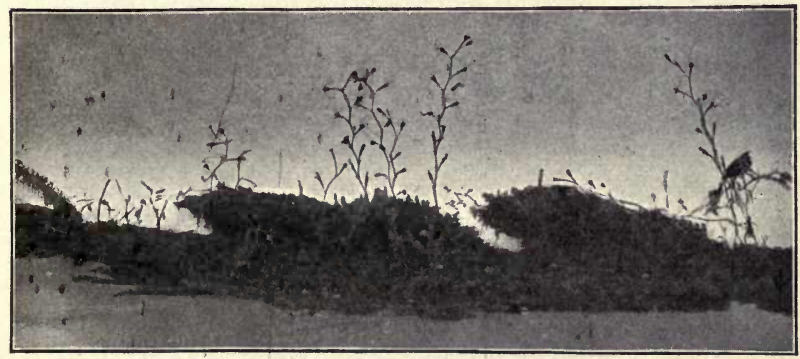

FTG. 199. - Several hydroid colonies each containing from 10 to 20 animals, growing on a plece of rotten wood in the ocean. The three lowest animals on the tall colony in the middle are reproductive polyps. Photograph enlarged four diameters. 


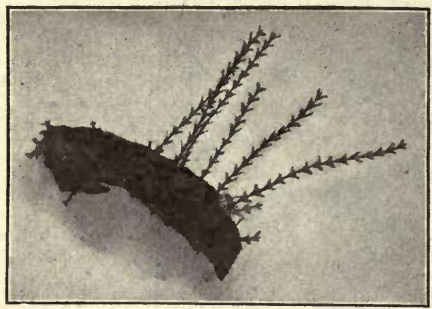

Fra. 200. - Several hydroid colonies (Sertularia) each containing from 20 to 30 animals. Photograph enlarged three diameters. zoöphytes or polyps and each has the same structure as the Hydra. There are two kinds of polyps One is known as the feeding polyp, and has for its function the securing and digesting of food to be distributed throughout the colony; the other is the reproductive polyp or blastostyle, which produces the young. The food polyps are recognized by the tentacles absent in the blastostyles which contain biscuit-shaped bodies, the medusce buids. These one by one emerge as minute umbrellalike forms called medusce.

They swim about freely, never attaining a sufficient size to be seen clearly with the naked eye, and the female produces eggs, while the male gives forth sperm cells each of which uniting with an egg fertilizes it, i.e., renders it capable of developing into an animal. The young one soon fixes itself to a weed or stick, and in a few weeks by producing budding young like the Hydra forms a colony. The hydroids are there-

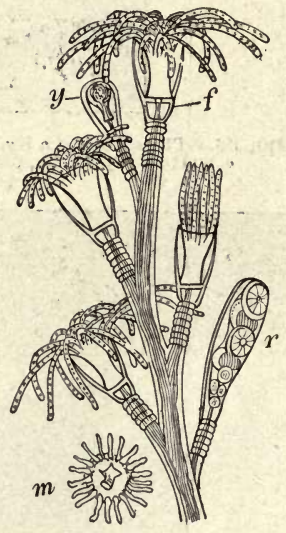

Fra. 201. - A hydroid colony of six polyps ; $f$, feeding polyp ; $r$, reproductive polyp; $m$, a medusa. 
fore said to exhibit alternation of generations, i.e., the egg of the medusa generation does not hatch into a medusa,

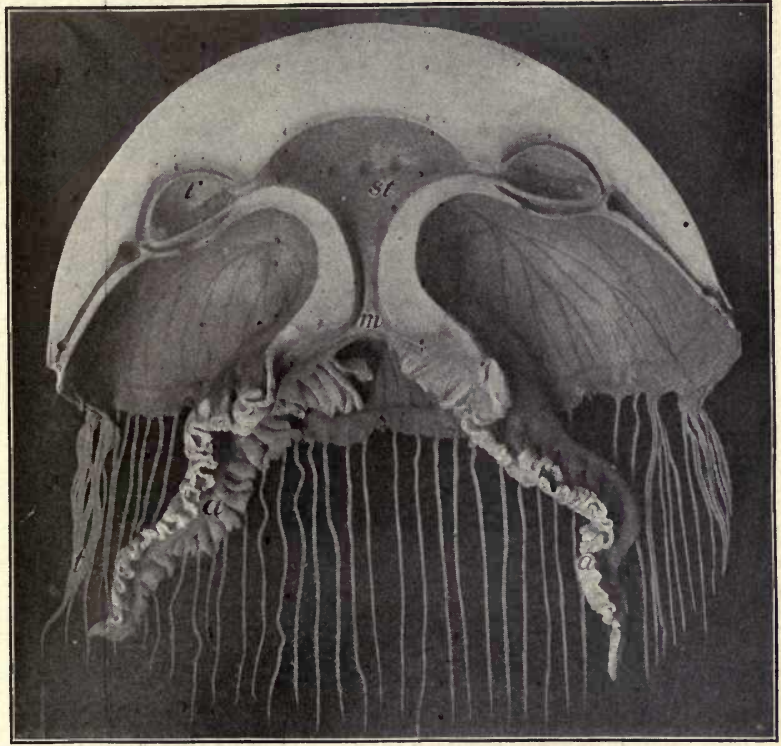

FIG. 202. - Half of a jellyfish; $a$, two of the four arms around the mouth $m ; r$, reproductive organs; $s t$, stomach ; $t$, tentacles

....

but develops into a fixed colony some of whose polyps produce medusæ (small jellyfish).

The large jellyfishes of the ocean, which are similar in structure to the medusæ just described, attain a diameter of several inches and possess tentacles a foot or more long 
bearing nematocysts. The stinging sensation one experiences upon picking up a jellyfish is caused by the discharge
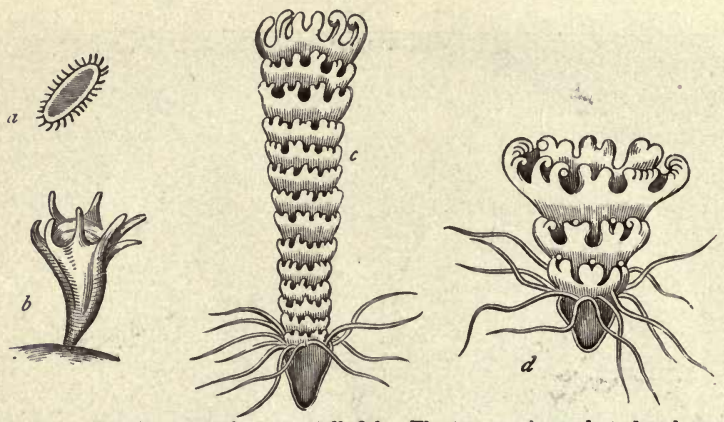

FIG. 203. - Development of young jellyfish. The top one is ready to break away. After Haeckel.

of these coiled stinging processes. Each egg deposited by the jellyfish produces a freeswimming young, which soon fixes itself to an object and assumes a form similar to the hydra and grows to the height of half an inch. It then becomes transversely divided into several parts, giving the animal the appearance of a pile of saucers. The top one soon swims free, and one by one the

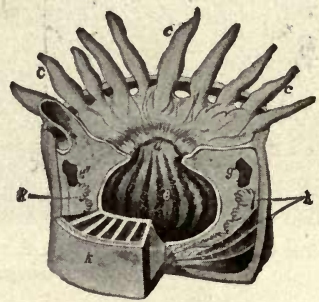

FrG. 204. - Sea anemonedissected ; $c$, tentacles; $d$, mouth ; $e$, stomach; white lines above $k$, the mesenteries. others are also separated and turning upside down lead the free life of the adult forms.

The sea anemones may be seen at low tide attached firmly 
to the rocks and wharves a short distance beneath the surface of the water. They vary in diameter from a fourth of an inch to two feet. The moment they are disturbed the numerous tentacles around the mouth are contracted, and the fleshy mass becomes a brown conical body.

The coral polyp is similar to the anemone, butmuch smaller. It secretes from the sea water lime which is deposited throughout its tissues to form a skeleton. Most

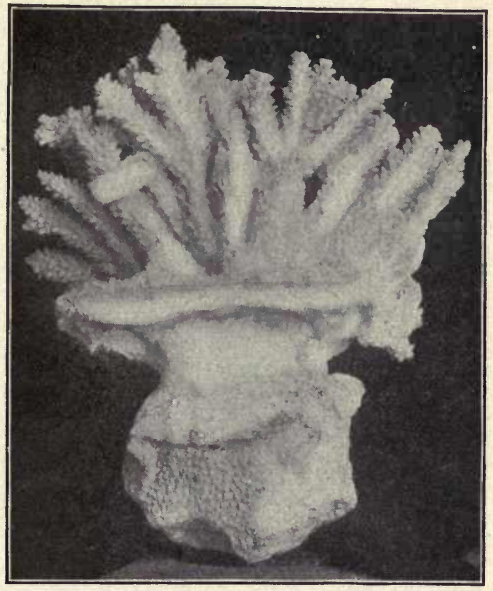

Fia. 205. - Coral. Each of the two thousand or more small projections is the work of one coral polyp. Photograph one third natural size.

corals, like the hydroids, bud freely and thus great masses of coral are formed. They dwell only in the warmer parts of the ocean.

\section{Porifera: Sponges}

The sponges are mostly ocean dwellers, only about thirty species being found in fresh water. A simple sponge, such as Grantia or Leucoselenia, growing near the surface of the water on $\operatorname{logs}$ and stones along the Atlantic coast, has much the same structure as Hydra, but the walls composed 
of three layers are perforated by numerous minute pores for the passage of water and food. The larger sponges are of a more complex nature.

The body of a sponge in addition to the fleshy material consists in some species of flexible fibers of spongin, such as make up entirely the commercial sponge when purchased.

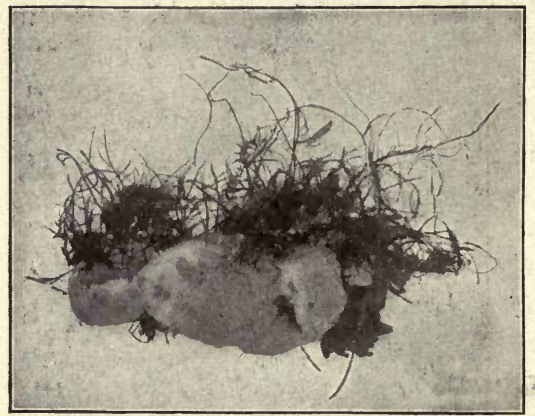

FIG. 206. - A fresh water sponge. Photograph natural size.

In other species like Grantia, lime spicules are present, and in a few kinds, including the fresh water forms, silicious spicules occur.

The fresh water sponges have a wide distribution, and may be found by looking for irregular more or less lobed cushionlike masses from one to four inches in diameter attached to weeds, logs, and stones in clear springs and ponds.

Sponges reproduce by eggs and also by internal buds called gemmules.

In the ocean, sponges are found at depths of from one to six hundred feet. The most famous sponge fisheries are those of the Great Bahama Bank in the West India region, and those of the Mediterranean and Red Seas. All sponges came from the Mediterranean Sea prior to the year 1840 , when the famous fisheries were discovered along 
the Bahama Islands. Seven or eight hundred craft are now engaged in the sponge regions of the West Indies, where the shallow water permits them to hook up the animals with a long-handled threepronged fork In the Mediterranean Sea the finest sponges grow at a depth of two hundred feet or more, and can be secured only by divers, many of whom work without diving suits and remain under water as long as three minutes. The deepest sponges are brought up with drag nets.

The skeleton of the commercial

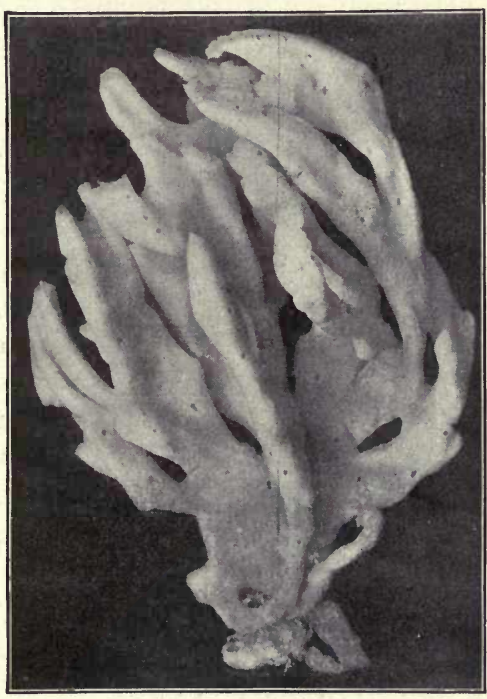

Fig. 207. - A salt water sponge. Photograph half natural size.

sponge composed of fine spongin fibers is cleaned free of the fleshy portion by means of bacteria which cause all flesh to decay or rot. Some species of sponges are found growing only on the backs and legs of certain crabs which are thereby concealed from theirenemies. Thecrabfavors the sponge by carrying it to new feeding grounds. Such mutually helpful association between animals is termed commensalism. 


\section{PROTOZOA : ONE-CELLED MICROSCOPIC ANIMALS}

The members of this phylum are single-celled animals, and so small that but few of them can be seen with the naked eye, and some are so minute as to be visible only under the highest powers of the microscope. They abound in the dust of the air, in the surface layers of the earth, and in the water, while many parasitic forms make their homes in the living bodies of the higher animals and plants, sometimes causing disease.

Slipper Animalcule (Paramœcium). - This is a representative of the class Infusoria, which includes most of the

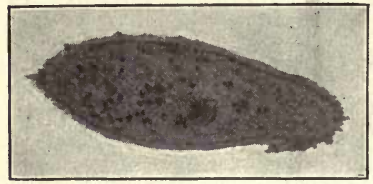

Fig. 208. - Slipper animaleule showing the nucleus, a dark circle, and the buceal groove on the lower side. Enlarged two hundred diameters. protozoa commonly present in infusions made by soaking grass, leaves, or flowers in water. Paramœcia may usually be secured by placing a bunch of dry grass in a dish of stagnant water for a week or two.

For study, a small drop of water containing a number of specimens should be transferred to a glass slip, and one or two minute threadlike green plants added to the drop before the cover glass is placed thereon. Having seen with the low power that the animals wanted are present in the mount, absorb with blotting paper the superfluous water about the edge of the cover glass, drop near its margin a half dozen pieces of paraffin, and with a red-hot nail held in a cork melt the paraffin so it runs slightly over the 
edge of the cover glass and thus makes an air-tight aquarium. I have kept amœba and some of the smaller infusoria alive in this way over two months. The Paramœcia usually live only a few days. The preparation must be kept in the light, not sun, so that the plants will give off the oxygen necessary to the life of the animals and also consume their excreted carbon dioxide.

The movement of the animal is effected by short, hairlike processes (cilia) covering the entire surface. The buccal groove beginning on one side opens into a mouth permitting

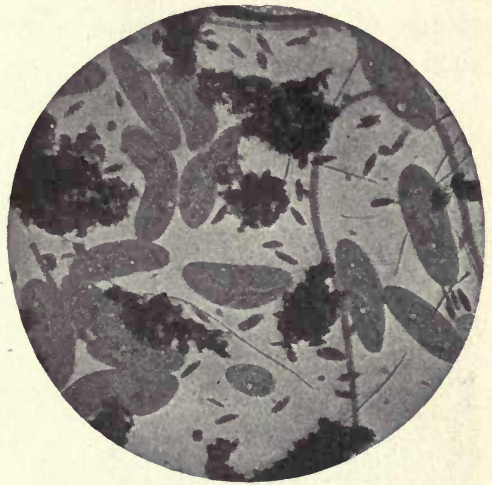

Fig. 209. - Living Paramœeia photographed through the microscope magnifying eighty diameters. the food to pass through a short gullet into the soft internal protoplasm (cell contents). They feed largely on bacteria. Near either end of the body may be seen a clear round spot, the contractile vacuole, which is an exit for the surplus water.

Paramœcium, like all other infusorians, reproduces by binary fission, i.e., divides its body into two equal parts, each of which in a day or two grows to the normal size. This process of division is easily seen, as about a half hour is required for its completion. Each of the new genera- 
tion is ready to divide again within twenty-four hours if the conditions are favorable. After the formation of a hundred or more generations they seem to become exhausted and must then be rejuvenated by a process called conjugation. This is the union of two individuals along their ventral surfaces by means of which a mutual exchange of protoplasm occurs. They then separate, and each is ready to divide again.

Bell Animalcule (Vorticella). - This is another infusorian common in stagnant water. It is easily recognized under

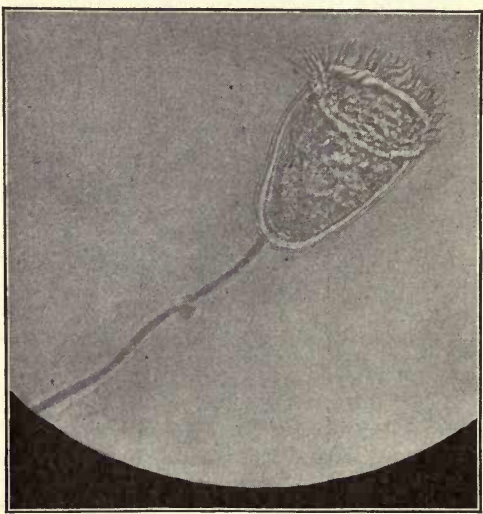

Fig. 210. - Photograph of a living bell animalcule, enlarged two hundred diameters. thelow power of the microscope by its bell-shaped body attached to a stem which occasionally contracts into a spiral. The cilia around the mouth are used to form a vortex drawing the food into its gullet leading blindly into the soft protoplasm.

Amœba. - This genus includes several species of the class Rhizopoda (root-footed), which are regarded as being the lowest in the scale of animal life. Seldom does one become large enough to be seen with the naked eye, but it is easily distinguished with a magnification of one or two hundred diameters. In some regions 
the Amœba is not easy to secure, but if a few sticks and leaves with their accompanying ooze from a stagnant pond be placed in a dish of water in an east or north window,

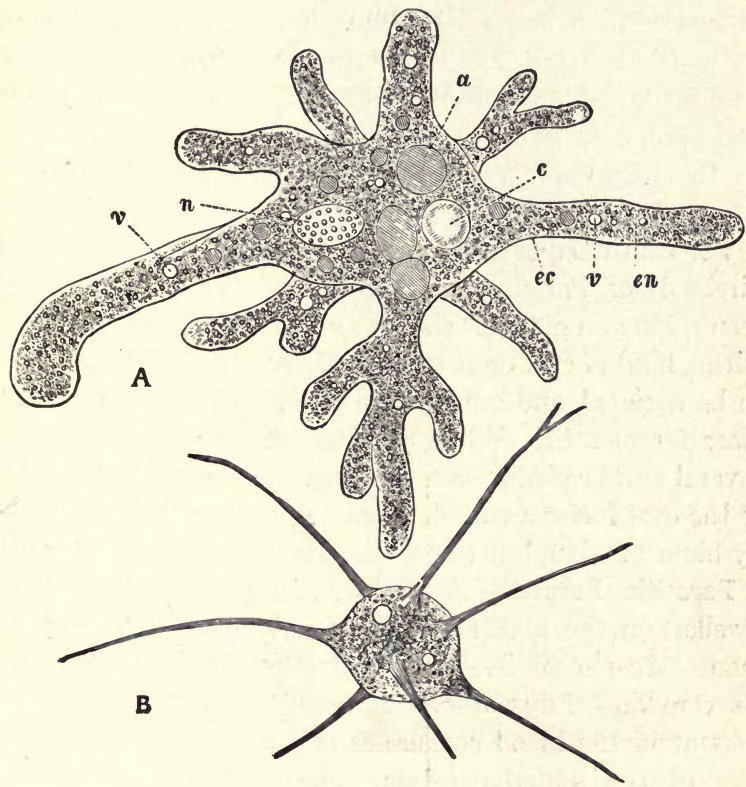

Frg. 211. - A, Amœba proteus; $B$, Amoba radiosa. $n$, nucleus ; $c$, contractile vacuole; $a$, food engulfed; $e c$, one of the nine pseudopods. After Leidy.

and a little green scum or water algæ added, large numbers usually develop. To secure them for study, scrape a little of the slime from a stick or leaf upon a glass slip, place on the cover glass, and examine with the low power. An 
Amœba may be recognized by its slow crawling and frequent changes in shape as it puts forth the blunt processes called pseudopods. It appears like a mass of granular colorless protoplasm streaming along inside of a transparent sac known as the ectosarc. It has no mouth but secures food by wrapping itself about any organic material which then passes through the ectosare into the soft protoplasm, called endosarc, capable of digesting it. The products excreted by the lungs and kidneys of the higher animals are also excreted by the one cell forming the amoeba.

For continued study, the Amœba should be mounted as directed for Paramœcium. Some of them may then be seen taking on globular shapes and surrounding themselves with a kind of cyst or coat. In this condition they are said to be encysted, and are capable of thus existing in a dried state for months. While encysted they often divide into several parts called spores, each of which upon the bursting of the cyst forms a complete animal. They also reproduce by binary fission, but this method is not common.

Parasitic Forms. - Several species of protozoans are dwellers in the higher groups of animals from worms to man. Amoba coli lives in the intestines of man and causes a severe kind of dysentery. Plasmodiun malarice is always present in the blood corpuscles of patients suffering from any of the malarial fevers. Mosquitoes of the genus Anopheles (Fig. 371) transfer the parasites from the sick to the healthy, and thus a large part of an entire community may become infected with this germ. It belongs to the class Sporozoa, which is so named because the animals in reproducing divide into a number of small bodies called spores. 
Chalk formers. - The Globigerino are among the most abundant protozoa in the sea. Nearly all surround themselves with a shell of soft calcium carbonate (chalk). A pint of ocean water in the warmer climes may contain millions of them. The shells of the dead dropping to

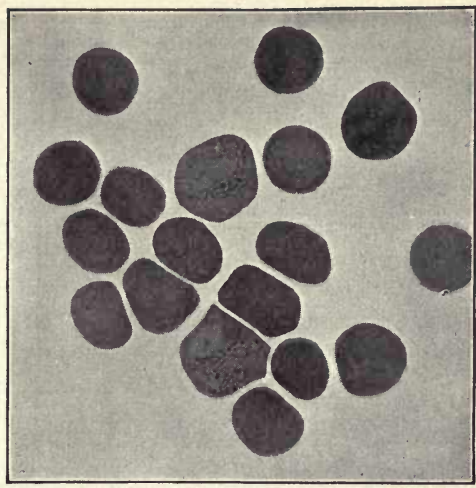

FiG. 212. - Photograph of human red blood corpuscles two of which contain the malarial parasite. Enlarged one thousand times.

the bottom of the ocean have formed a thick layer of ooze over much of the ocean bed. The great chalk cliffs in England, and the chalk beds

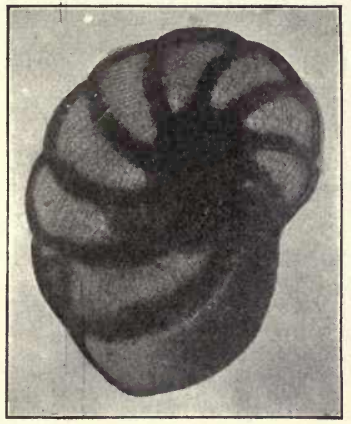

Frg. 213. - Shell of Globigerina. Photograph enlarged forty diameters. in Ireland, Denmark, Central Europe, North Africa, Syria, Central Asia, Texas, Kansas, and South Dakota are composed almost entirely of the shells of Globigerinæ that lived ten millions of years ago or more. The small piece of chalk used by the carpenter is made of millions of the skeletons of these tiny protozoans.

The protozoa were no doubt the first animals on earth, 


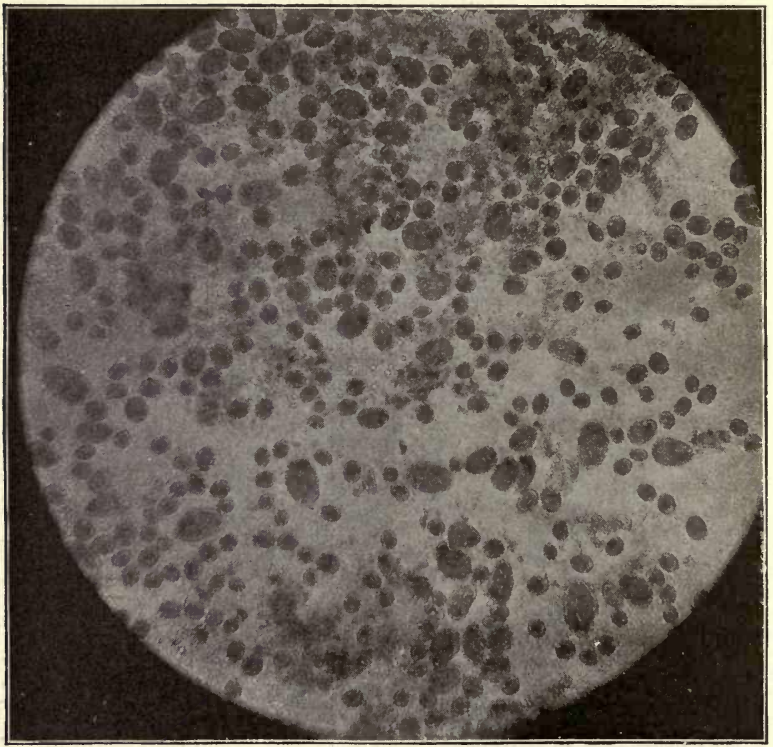

FIG. 214.-Photograph of the Protozoans in one twentieth of a drop of stagnant water.

and inasmuch as two new animals are formed by the halving of the parent the tiny creatures may never die of old age, but so long as food and environment are favorable live millions of years. They are therefore sometimes spoken of as the immortal animals. The Protozoa, are most numerous in stagnant water where as many as ten thousand may be present in a single drop. Ordinary drinking water, however, seldom contains more than a dozen in a quart, and good spring water often has none. 


\section{PART III \\ VERTEBRATA}

\section{PISCES}

THE four chief orders of this class are the round-mouthed fish (Cyclostomata), the cartilaginous fish (Elasmobranchii), the bony fish (Teleostomi), and lung fish (Dipnoi).

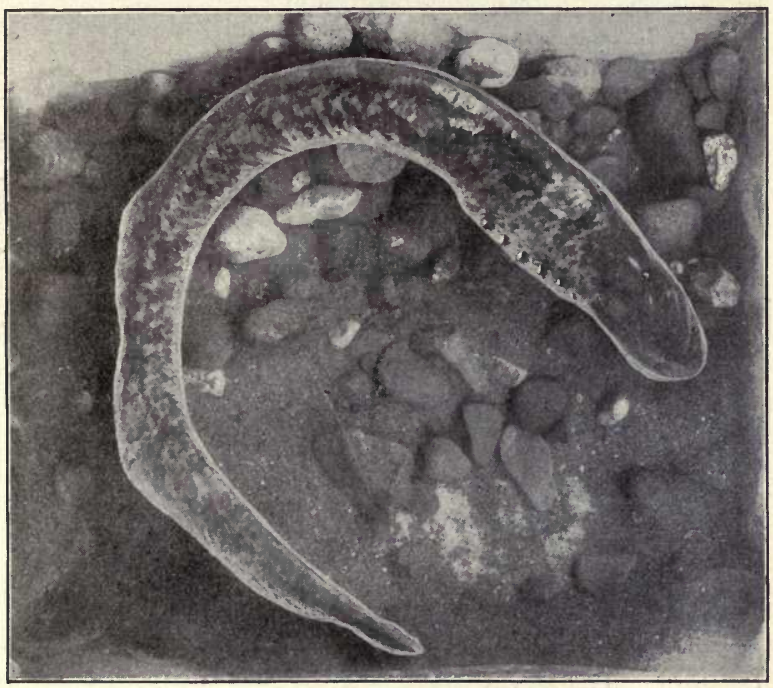

FIG. 215. - Ocean lamprey. Photograph one fourth natural size. 'The holes on the side behind the eyes are the gill openings. 
Round-mouthed Fish. - There are about a dozen species in this country, of which the commonest is the ocean lamprey (Petromyzon marinus) attaining a length of more than

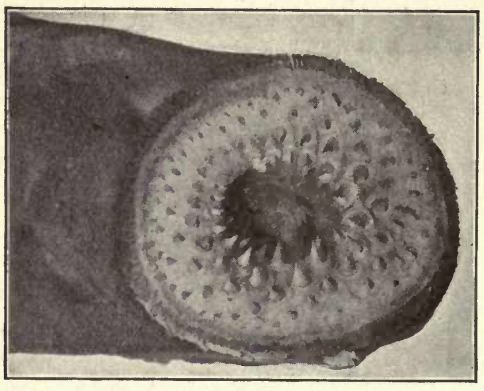

FIG. 216. - Photograph of the mouth of a living lamprey sucked fast to a piece of glass. Natural size.

two feet. It ascends the streams along the Atlantic coast to the distance of more than a hundred miles for the purpose of spawning, which in the latitude of New York occurs about the middle of May. The nest is made of gravel and sand encircled by stones nearly as large as a man's head, which they suck fast to with their peculiar mouth and drag

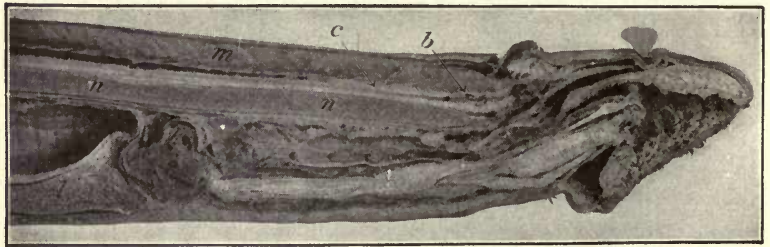

FIG. 217.-Median longitudinal section of the anterior fourth of a lamprey eel. $b$, brain; $c$, spinal cord; $m$, muscles of the back; $n$, notochord ; $l$, liver; $h$, heart. Photograph.

together. The larval young (Ammocœtes) bury themselves in the mud along the banks of the streams, where they remain three or four years until transformation to the adult 
state occurs. They then descend to the ocean and remain there several years, after which they return to the scene of their youth for breeding purposes, and a few days later die without having regained the ocean. The adult is a parasite living on the blood and mucus rasped from the sides of fish. The lake lamprey of New York is probably a descendant of the ocean lamprey, having been cut off from the salt water by the drying up of the streams many years ago. It is destructive to food fishes, preying on nearly thirty different species.

The lampreys are not true fish, as they lack paired fins containing spines or bony rays, and have only one nostril, which opens on top of the head in the median line. Jaws are wanting. The skull is made of membrane and cartilage, and the spinal cord lies in a fibrous tube with bars of cartilage along the sides. Beneath the spinal cord is a stiff gelatinous rod known as the notochord, which is present in the very young stages of all vertebrates, but usually its place is later occupied by the bodies of the bony vertebræ (Fig. 227).

Cartilaginous Fish. - The fish whose skeletons are made of cartilage instead of bone live in salt water. They are the sharks and rays. Many of them are predaceous creatures, and their presence accounts for the scarcity of some of the species of fish desired for food by man.

The sharks are represented along our coast by several species, of which the best known is the dogfish (Squalis acanthias), which attains a length of three feet. During the summer it congregates in great numbers along the Maine and Massachusetts coasts, and often prevents the fishermen from eatching any codfish by seizing the bait 
the moment it is thrown into the water. In 1883 their vast numbers completely destroyed the fishing. They bit the sails or oars hanging over, and even attacked persons falling overboard. They were caught by the thousands, their livers being used for oil and their bodies carted to

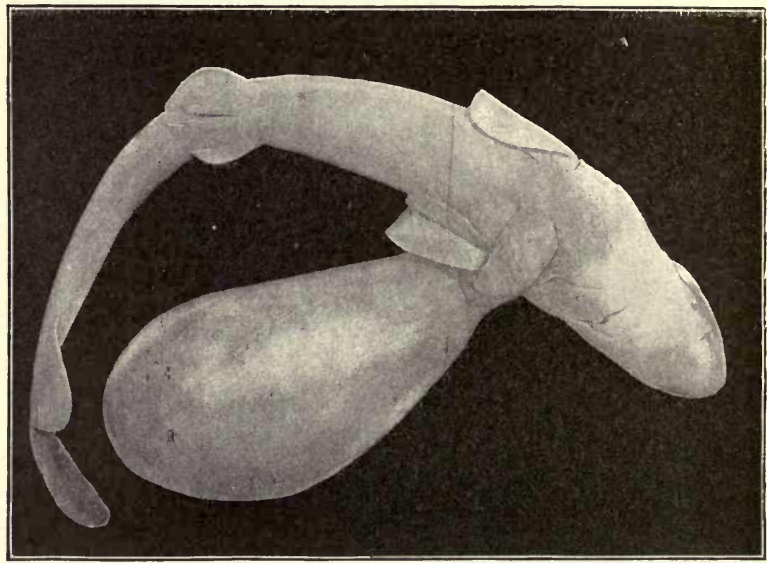

FiG. 218. - The young of the dogfish removed from the body of its parent. Ventral aspect showing the attachment of the large yolk sac to the body, and also the crescentic mouth. Five gill slits are seen on one side. Photograph half natural size.

the farms for fertilizer. They feed upon refuse and smaller fish.

The blue sharks and basking sharks of the northern Atlantic reach a length of over thirty feet, while the Indo-Pacific basking shark is known to exceed forty feet in length. The man-eater or white shark, ranging from the Atlantic coast to Australia, seldom attains a size of more than thirty feet. 
In some species of sharks the young are born alive, but in others the eggs are deposited in a tough, usually flattened case with tendrils by which it may be fixed to seaweeds. Most of the one hundred and fifty species of sharks are characterized by five gill openings on either side of the head, underneath which the mouth is situated.

The rays differ from the sharks in having the gill openings beneath the flat disk formed by the body and the expanded pectoral fins. The common skate of our Atlantic coast (Raja erinacea) grows to a length of nearly two feet and is nearly as broad. The sawfishes, some of which are fifteen feet long, are remarkable for the prolongation of the snout in a saw-edged sword nearly one fourth the length of the fish. They range from Cape Cod southward. Not less noted is the electrical fish (Torpedo marmoratus) found along the New Fngland coast. A specimen two or three feet long is capable of imparting a severe shock to any one seizing it along the sides of the body.

Bony Fish (Teleostomi). - This order is made up of

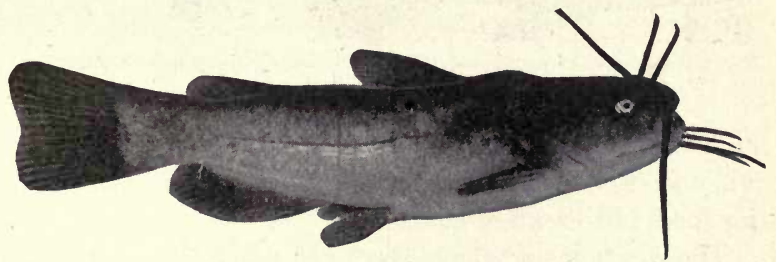

FIG. 219. - The bull head (a catfish). Photograph one fourth natural size.

thousands of species which are characterized by a bony skeleton, usually a scale-covered body, and gills protecter by a plate projecting backward called the opercu? um. 
The catfishes have a scaleless skin, a pair or two of long barbels (feelers) projecting from the upper jaw, and the first ray of the dorsal and pectoral fins is a stout spine with which the animal can inflict serious wounds. There are nearly a thousand species widely distributed over the world and are highly valued as food. The great catfish of the Mississippi River attains a length of five feet and weighs one hundred and fifty pounds. The Bullhead or horned pout (Ameiurus catus) is common in streams east of the Mississippi. The eggs of some species are deposited under objects in the streams and guarded by the male, while in other species the eggs are carried in the mouth until hatched.

The suckers are covered with scales, have toothless jaws,

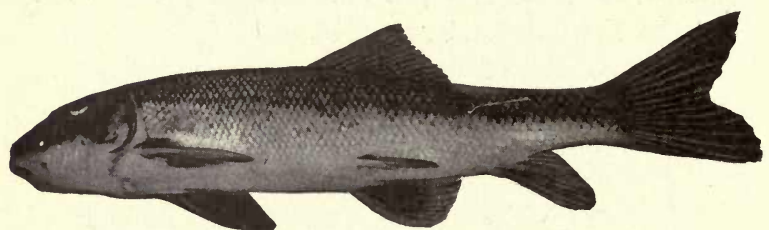

FIG. 220.-Common river Sucker (Catostomus teres). Photograph one third natural size.

and thick, fleshy lips forming a nearly circular mouth. They feed on plants and small animals. The flesh is used for food, but is rather coarse.

The herrings, of which there are more than a hundred species, are found in many parts of the ocean, and some come to the fresh water to spawn (lay eggs). The common herring (Clupea harengus), about a foot long, frequents the north Atlantic coast where they associate in shoals number- 
ing millions and swim near the surface to secure the worms, insects, and crustaceans. They are therefore easily taken in nets.

The shad (Clupea sapidissima) is an important food fish, passing the greater part of its life in the ocean along the Atlantic and Pacific coasts. When mature it ascends a stream, often traveling more than a hundred miles to deposit its eggs, numbering many thousands. On these trips the fish are caught with seines. Like the lampreys, a few

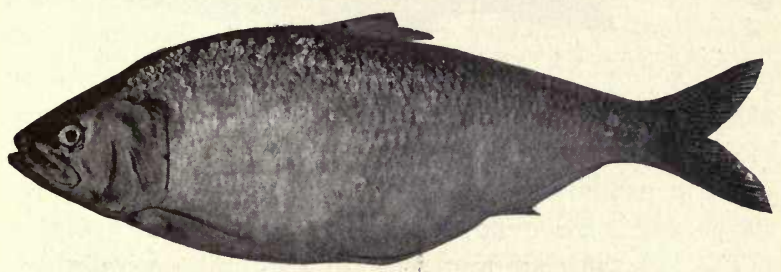

FrG. 221.- Photograph of the shad one sixth natural size.

days after spawning they die. The shad fisheries of the Atlantic coast are worth two millions of dollars annually.

The salmon are the most valuable of all the food fishes. The five species of the Pacific coast salmon, canned in such immense quantities, yield an annual revenue of thirteen million dollars. During most of their life they live in the ocean, but ascend a stream, often two or three thousand miles, to spawn, after which they die. It is during their migration for breeding purposes that they are eaught in such vast numbers. The quinnat or chinook salmon, attaining a weight of fifty pounds, affords the most delicious meat, but they have become somewhat scarce lately owing 
to the vast numbers eaught. A few species of salmon inhabit the streams along the north Atlantic coast.

The trout are the most delicious of all the food fishes. Of these the brook trout (Salvelinus fontinalis), orna-

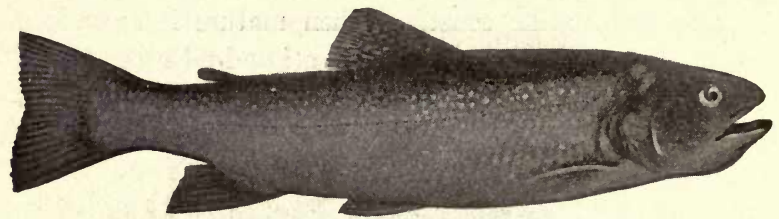

FiG. 222. - The brook trout. Photograph one third natural size.

mented with red spots, is the most famous. It inhabits the cold streams from Maine to Dakota, and is often cultivated in ponds. Owing to insufficient protection by law, the supply is becoming limited.

The cave fishes are represented by several species in this country, dwelling in subterranean streams. Those living

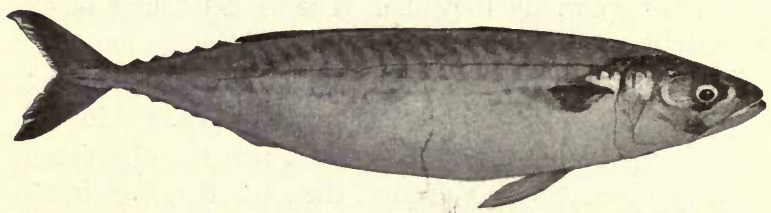

FIG. 223. - Photograph of the common mackerel one third natural size.

in the Mammoth Cave of Kentucky are white and entirely blind. Their ancestors possessed eyes, but lack of use throughout many generations resulted in blindness. Quite as remarkable as the cave fish are the flying fish of the ocean. They dart obliquely out of the ocean and spread the broad 
fins which act as parachutes, enabling them to soar through the air nearly an eighth of a mile.

The sea horse (Hippocampus) is a member of the pipefish family. It is only a few inches long, and dwells in the ocean. The male cares for the young in an abdominal pouch.

The codfishes number ninety species, of which Gadus callarius is the most important. It reaches a length of four feet. In November each mature female deposits about ten millions of eggs which hatch floating on the surface of the sea. Vast numbers of codfish are caught with hooks and lines along the north Atlantic and Pacific coasts, and are much valued for food both in the fresh and salted state.

The mackerels include about seventy species, all living in salt water. They frequent the northern shores at the spawning season in early summer when they appear in large schools. At this time great numbers of the common mackerel (Scomber scombrus) are taken in nets along the New England coast. Those not sold fresh are packed in brine.

The sunfishes number a dozen species in the United States. The green sunfish (Lepomis cyanellus), six or seven inches long, is common in the small streams east of the Mississippi. In early summer it forms a nest more than a foot in diameter in shallow water. Coarse gravel lines the margin of the concave area and near the center very fine gravel is present on which the eggs are deposited. The male remains over the nest, keeping it clear of dirt with the tail, until the eggs, of which there are several thousand, hatch. 


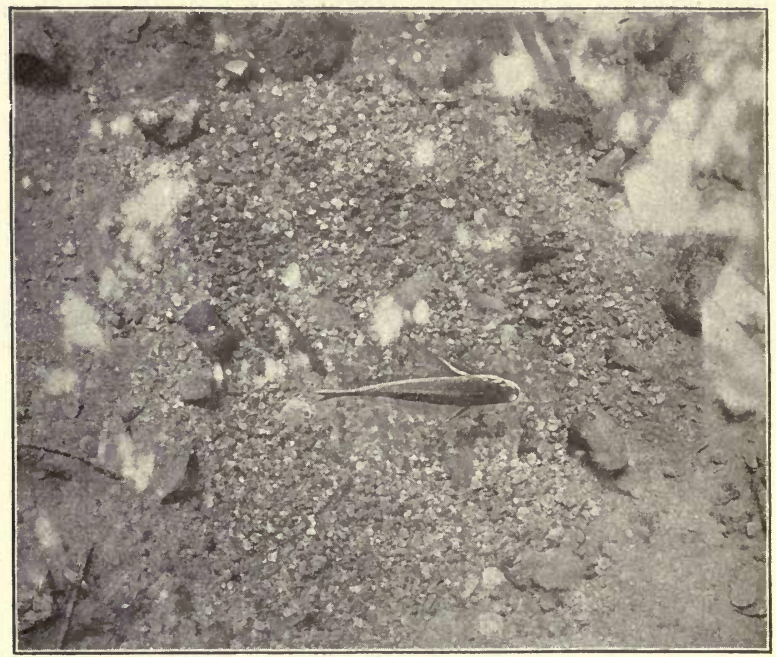

FIG. 224. - Green sunfish on her nest. Photograph one fifth natural size.

The flatfishes or flounders are valuable food fish of the sea. The halibut is the largest, weighing four hundred pounds, but the flounder (Pleuronectes americanus) is most frequently seen in market. It is remarkable for having two eyes on one side of the head and none on the other. It swims on the side, the lower surface, which is white, always remaining in that position. The young are symmetrical, having an eys on either side of the head and swimming upright.

Lungfishes (Dipnoi). - In this order only three species are included. They live in Australia, Africa, and South 


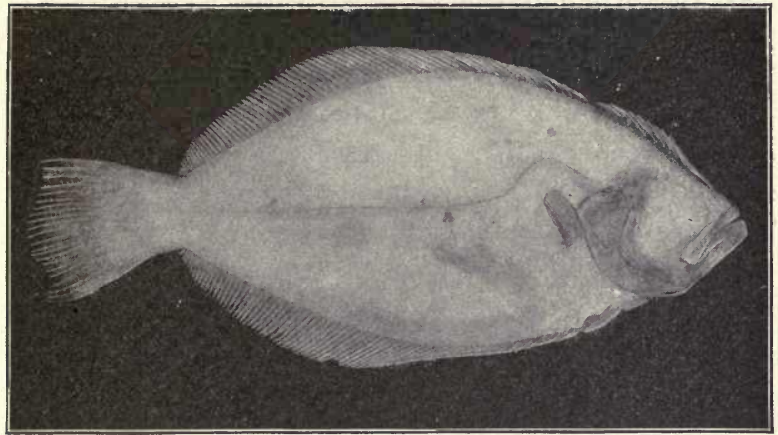

FrG. 225. - Photograph of the flounder from the lower side. Half natural size.

America. The feature from which the group takes its name is the possession of a lung or lungs corresponding in position to the air bladder in other fish. Gills are also present, so that these fish can live either in water or on land.

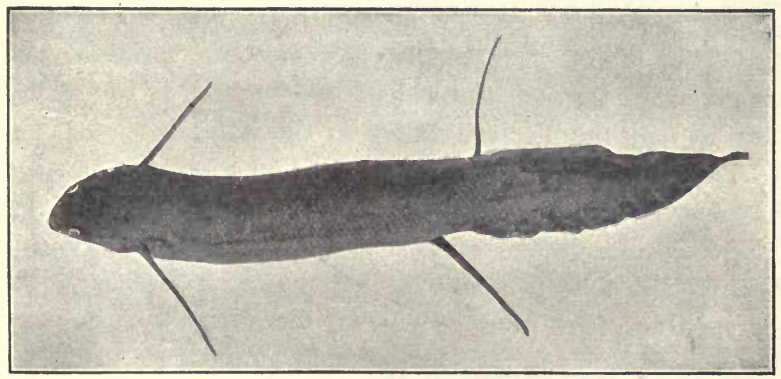

Fig. 226. - Lepido ziren, the South American lungfish. Photograph one fourth natural size. 
The African mudfish buries itself in the mud for several months during the dry season.

The members of the class Pisces are distinguished from all other vertebrates by the absence of limbs, the presence of gills throughout their entire life, and a simple heart consisting of only one auricle and one ventricle. The fish, amphibians, and reptiles are often referred to as the coldblooded animals and the other two classes, birds and mammals, as warm-blooded animals. This distinction is due to the fact that the two higher classes nuaintain a constant temperature of from ninety-eight to one hundred and five degrees Fahrenheit whether the surrounding atmosphere be hot or cold. A fish, frog, or snake varies its temperature in accordance with that of the atmosphere. In winter they may have a temperature near the freezing point, while in summer it may be almost a hundred degrees.

The air bladder, present in all forms except the roundmouthed fish, flatfish, sharks, and rays, lies on the dorsal side of the body cavity above the alimentary canal and in some, such as the herring and trout, opens by a duct into the pharynx. Usually, however, the contained gas is given off through the walls. Its function is to aid the fish in maintaining its position in the water.

To understand the parts of a fish one of the smaller species, such as the catfish, sunfish, or porgy, should be dissected after the external features have been noted. An eye lies in a deep socket on either side of the head, and is capable of rotation in several directions by means of muscles. No eyebrows or eyelids are present, as in higher forms. The nostrils are two pairs of small openings near the. tip of the nose. They lead into the nasal cavity over which 
the olfactory nerve, the nerve of smell, is distributed. This cavity does not communicate with the mouth, as in the Dipnoi and all the higher vertebrates. There is no external ear. The scales, overlapping each other like the shingles of a house, are calcified outgrowths of the skin to protect the body. The unpaired dorsal fins vary from one to three. A pair of pectoral fins is present just back of the gill open-

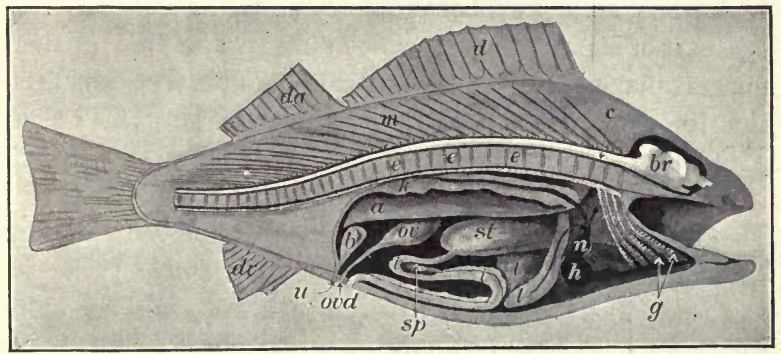

FIG. 227. - Dissected flsh. $a$, air bladder; $b$, urinary bladder ; $b r$, brain ; $c$, spinal cord ; $d$ and $d a$, dorsal fins ; $d v$, anal fin ; $e$, body of the vertebræ; $g$, gills receiving the blood from the ventral aorta leading out of the heart $h ; i$, intestine; $k$, kidney; $l$, liver; $m$, spines of the vertebræ; $n$, auricle of the heart; ov, ovary; ovd, oviduct; st, stomach; $s p$, spleen; $u$, nreter. Drawing by W. H. Reese.

ing, and behind and below these is usually a pair of ventral fins. The anal fin present in some forms is single, and behind the opening of the alimentary canal. By removing the entire ventral abdominal wall, most of the organs may be seen.

Teeth are usually present not only on the jaws, but in some species on the vomer at the roof of the mouth and on the gill arches. Vertical openings between the four 
gill arches are the gill slits permitting the water to pass from the pharynx to the exterior. The flap covering the gills externally is the operculum. A narrow tube, the gullet or esophagus, leads from the large pharynx to the stomach, from which extends the somewhat tortuous intestine to its opening at the root of the tail. The liver may be recognized by its large size and red color.

The intestine, as well as the other organs, is held in place by a transparent membrane known as the mesentery. This is a part of the peritoneum, which appears as a thin, glistening membrane lining the entire abdominal cavity and closely enveloping most of the organs therein. The elongated narrow white organ is the pancreas, adjacent to which there is in most species a small dark red body, the spleen. The reproductive organs lying dorsal of the stomach are white in the male and yellowish in the female. The air bladder with a wall as thin as paper is of a grayish-white color, and lies against the spinal column. To see the kidneys, one must look carefully for a pair of flattened brown bodies lying closely against the vertebral column in the dorsal side of the body cavity.

With a heavy knife the top of the skull may be removed, and the parts of the brain with several of the ten pairs of nerves issuing from its ventral aspect noted. By cutting away the roof of the spinal column, the spinal cord, and each nerve connected with it by two roots may be observed. The eye cut into with a sharp knife reveals three coats: an outer tough one, the sclerotic; a thin black one, the choroid; and an inner pinkish one, the retina. The almost round crystalline lens lies between the watery or aqueous humor contained in the front chamber of the eye and the 
glassy or vitreous humor filling the posterior chamber of the eye. The ear composed of the three semicircular canals opening into the oval sac, called the vestibule, may be seen in part by shaving off the side of the skull in the posterior part.

\section{I6. AMPHIBIA}

The Amphibians, often called Batrachians, derive their name from the fact that many of the species live a part of their life on land and breathe by lungs, while the other part is spent in the water where gills must be used. The members of this class are distinguished from both the fish and the reptiles by the absence of scales. They are divided into three orders, the Urodela, Anura, and Gymnophiona.

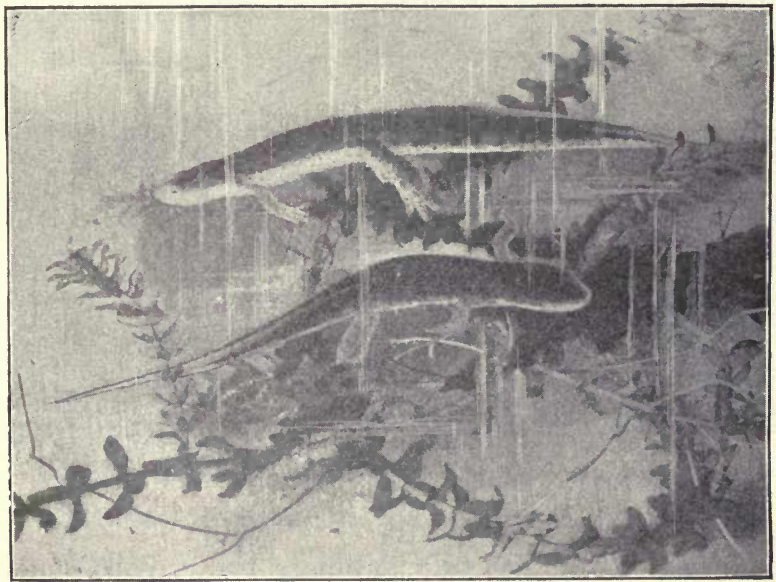

FIG. 228. - Photograph of newts nearly natural size. 


\section{Orodela: Salamanders}

This order is characterized by the presence of a tail. The newt (Diemyctylus viredescens) may be seen from March to December in quiet ponds of water and captured

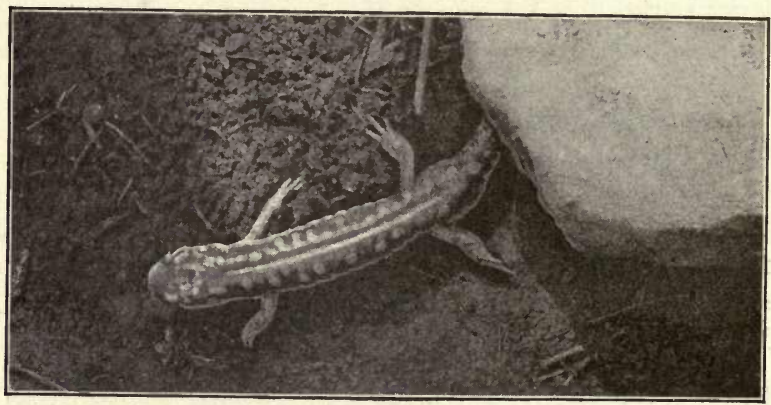

Fia. 229. - Photograph of large blunt-nosed salamander found under a stone at the water's edge. One third natural size.

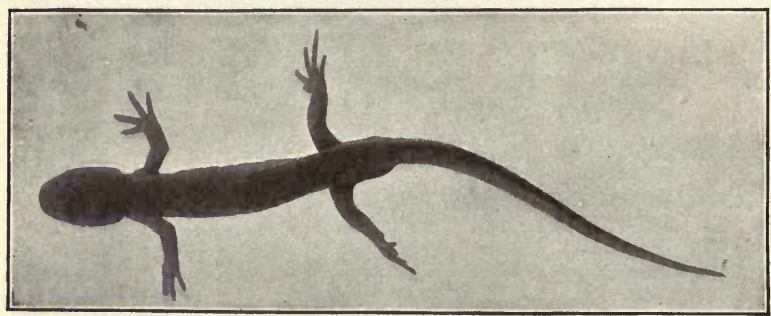

FIG. 230.- Photograph of Amblystoma opacum half natural size.

with the net for the aquarium. It relishes bits of beef and earthworms, and will devour a hundred mosquito larvæ daily. 
The large blunt-nosed salamander (Amblystoma tigrinum) and the gray species (Amblystoma opacum) may often be dipped up with a long-handled net from the sluggish waters near woodlands where they come in early spring to breed. The eggs, numbering several hundred, appear like shot in a colorless, jellylike mass of albumen as large as the human fist.

The red-backed salamander (Plethodon cinereus) is com-

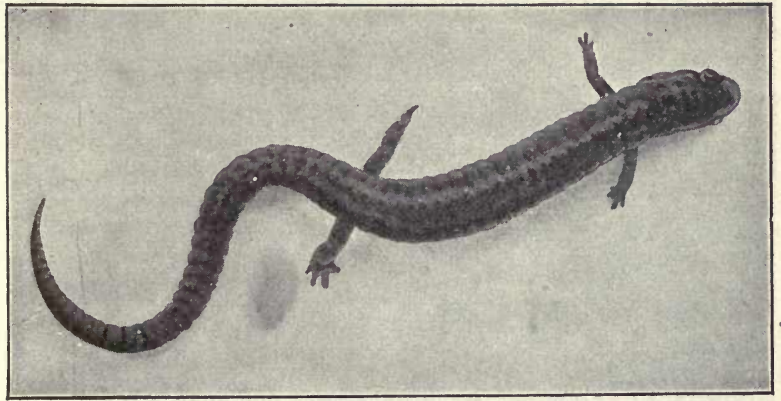

FiG. 231.-Plethodon cinereus. Photograph natural size.

mon under stones and logs in and near the woods. The mountain salamanders of the genus Desmognathus are often found under the loose stones in the cold forest streams of the highlands. Though most of the amphibians have lungs in the adult state the species of the genera Spelerpes and Plethodon have neither gills nor lungs when mature. The blood is relieved of its carbon dioxide and receives oxygen by means of the capillaries lying near the surface 


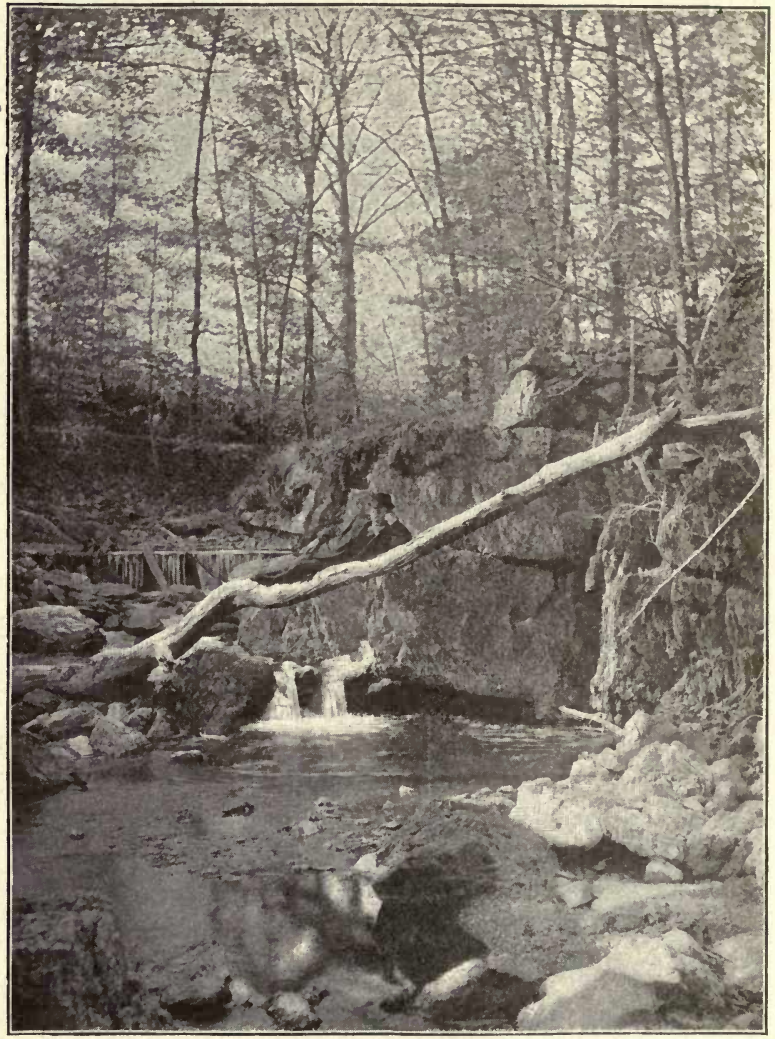

FrG. 232. - Home of the salamanders. 
of the skin and in the mucous membrane of the mouth and throat.

The mud puppy (Necturus maculatus), abundant in the Great Lakes and the waters near by, is remarkable

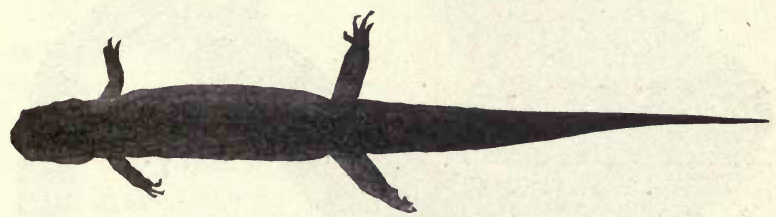

FrG. 233. - Desmognathus, the mountain salamander. Photograph natural size.

in that it possesses both gills and lungs in the adult state. Like characters are exhibited by the blind salamander (Proteus anguineus) in the caves of Austria and an allied form

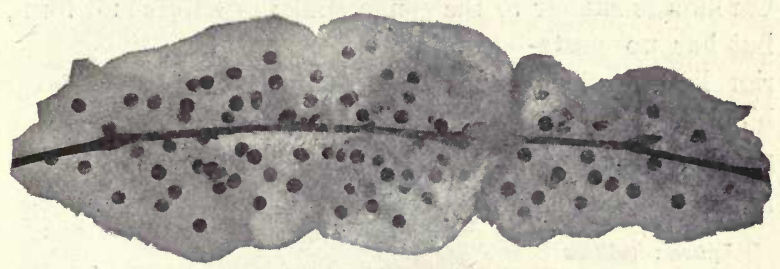

FrG. 234. - Photograph of Amblystoma eggs in water. Natural size.

found in the caves of Texas. The hellbender (Cryptobranchus alleghaniensis) is the largest of our salamanders. It lives in the streams of the Ohio and the Susquehanna valleys. The congo snake, which reaches a length of nearly three feet, inhabits the ditches and stagnant ponds 
from Arkansas to North Carolina. Its limbs, two or threetoed and less than an inch long, illustrate the effect of dis-

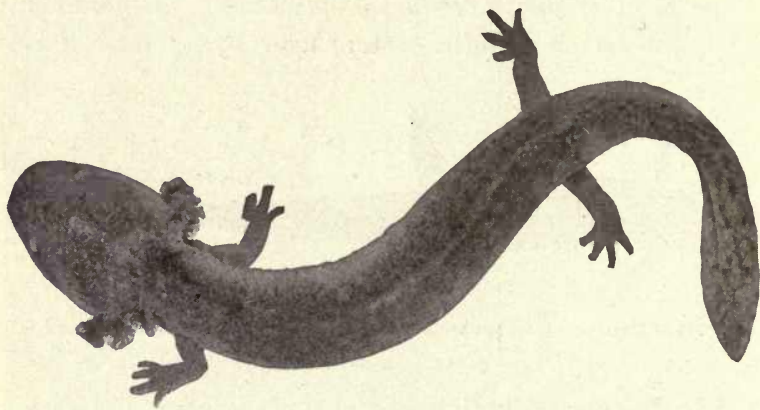

F1G. 235. - The mud puppy or water dog, showing the gills projecting from either side of the neck. Photograph one third natural size.

use of an organ. The mud eel (Siren lacertina) of South Carolina is similar to the congo snake in habits and form, but has no posterior limbs and exhibits external gills like the mud puppy

Anura : tailless

Amphibia

This order includes the frogs and toads which are found in nearly all parts of the world. In the

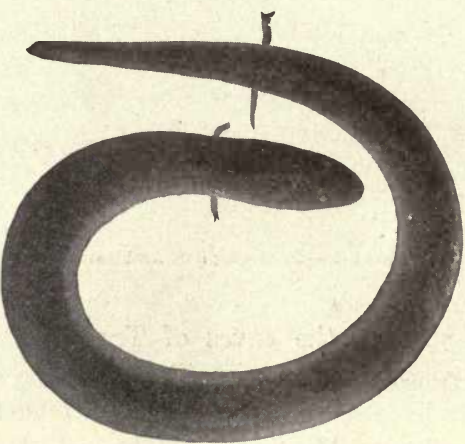

FrG. 236. - Photograph of the congo snake one third natural sizo 
adult stage they are provided with lungs, but respiration is carried on to a large extent through the skin, especially in the frogs spending much time under the water.

The bull frog (Rana catesbiana) is the only amphibian much valued for food. The length of a full-grown specimen from the tip of the nose to the end of the outstretched

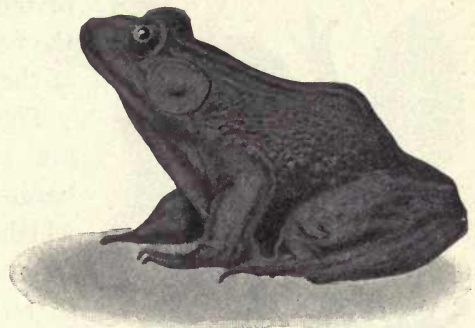

FIG. 237. - The green frog, showing the tympanic membrane (ear drum) just back of the eye. Photograph half natural size by Overton.

hind legs is nearly two feet. It may be distinguished from

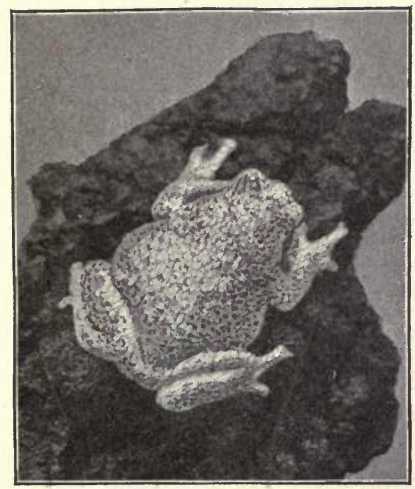

FiG. 238. - The common tree frog two thirds natural size. Photograph was taken just after it was transferred from a sheet of white paper. Twenty minutes later it was the same color as the oak bark. the other frogs by the fact that the web of the foot reaches to the tip of the fourth toe and the back is of a greenish color with small faint dark spots. Thousands of dollars' worth of frogs' legs are sold annually in the city markets. The green frog (Rana clamitans) is characterized by a tympanic membrane larger than the eye and the presence of a fold on either side of the back. 
The commonest of our frogs is the leopard frog (Rana pipiens) distinguished by the two rows of irregular black

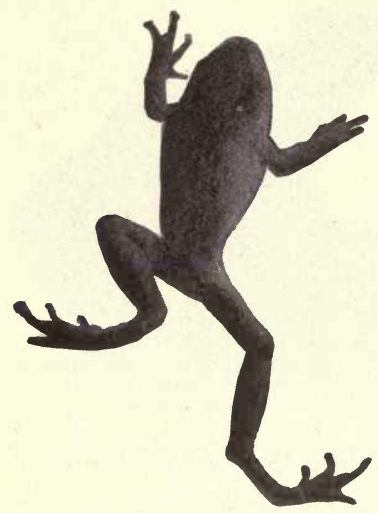

Fla. 239. - The spring peeper. Photograph natural size.

blotches on the back and the bars on the upper surface of the legs.

The tree frogs or tree toads are so named from their habit of climbing trees, to which they adhere by means of small expansions at the extremities of the toes. They have the power to change their color to harmonize with their surroundings. The common tree frog (Hyla versicolor) is the one giving the high trilling note prophetic of the approaching storm: The Spring peeper (Hyla pickeringii) announces the coming spring by its clear shrill whistle "Uh-e-e-t, wh-e-e-t, wh-e-e-t," uttered so continuously at nightfall that every meadow and swamp seems to be the home of thousands. They may be caught by wading among them with a lantern and then remaining quiet about ten minutes until one moves Frg. 240.-The toad one third sufficiently near to be grasped.

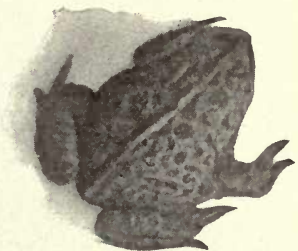

Toads differ from frogs in having no teeth in either jaw, and usually the skin presents a warty appearance. The 
frogs prefer moist places, but the toads seek a dry habitat in yards and gardens where they are of great service in destroying flies, slugs, and noxious insects. One hundred and forty-nine toad stomachs examined by Kirkland showed three fourths of the food to consist of insects of which one fourth were cutworms and tent caterpillars. The stomach of one toad contained fifty-five army worms, and that of another
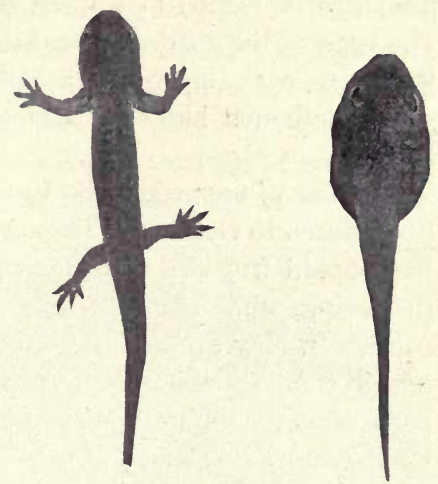

Fig. 241. - Larva of Amblystoma and of the frog, three months old. Photograph natural size.

thirty-seven tent caterpillars. Bufo lentigenosus is the only species of toad east of the Rocky Mountains.

\section{Gymnophiona}

The members of this order are tailless and limbless forms, living in Southern India, Southern Africa, and Central and South America. They are covered with scales, and in other ways resemble snakes.

The breeding habits of the majority of the amphibians are similar. The eggs are usually deposited in the water, but the congo snake protects hers beneath a log or stone, while a South American frog, Pipa, carries the eggs imbedded in the skin of the back. The eggs of most of the 
frogs and the Amblystoma appear as dark bodies of pinhead size imbedded in a mass of clear, jellylike albumen. The eggs of the toad are deposited in strings. The newt fastens its eggs singly within little tufts of aquatic leaves, while Plethodon hides its eggs under stones and logs on land.

The time of year when the various species breed extends from March to October. The eggs of the Amblystoma and the leopard frog are found as soon as the snow melts in the spring, while the green frog and brown frog spawn in April. In May or June the common tree frog attaches its eggs in small masses to stems of weeds and grass in shallow pools, and the bullfrog seldom spawns before July. The toad scatters its strings of eggs over the stones and brush in any small pool or pond during late April and early May. The breeding season of the newts extends from April to July, and some of the large urodels lay their eggs in the autumn.

The young of the amphibians are known as larvo or tadpoles. They dwell in the water and breathe by means of gills. In the case of frogs and toads, the food consists largely of vegetable matter, which fact accounts for the great length of the intestine in these forms. The intestine of the adult feeding on animals is not one fourth as long as that of the larva. The Amblystoma larvæ feed on aquatic insects, such as mosquito larvæ and pupæ, and therefore have a short intestine, as nutrition is easily secured from animal matter. The length of the larval period varies in the different species. For the toad it is usually about two months, while in some frogs it lasts six months and in others more than a year. Many of the salamanders pass 
the winter in the larval stage, and one species of the Amblystoma, the Axolotl, continues throughout life in the larval state, unless forced to terrestrial habits by the drying up of the water. In the Anura, metamorphosis to the adult state involves the absorption of the gills and the tail, and the development of lungs, and an exchange of animal for a vegetable diet. After the first few days of larval life,

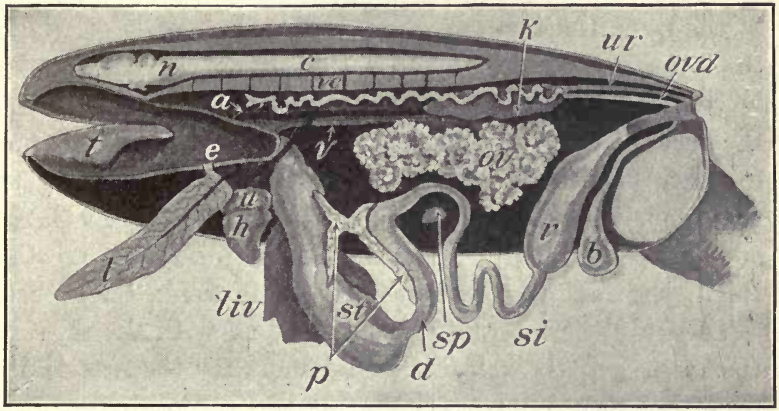

Fig. 242. - Frog with the left side eut away and some of the organs pulled downward. $a$, aorta leading from the ventricle; $b$, bladder; $c$, spinal cord surrounded by the vertebral eolumn of bone; $d$, small intestine; $e$, opening of the lungs into the pharynx ; $h$, ventricle of the heart ; $k$, kidney ; $l$, lung ; liv, liver ; $n$, bratn ; ov, ovary ; ovd, ovlduct ; $p$, pancreas ; $r$, rectum ; $s p$, spleen ; $s t$, stomach; $t$, tongue; si, small intestine; $u$, left auricle; $u r$, ureter; $v$, vena cava ; $v c$, body of vertebra.

the frogs and toads do not have external gills like the salamanders, but the gills are on arches and covered similar to those in fish, but only one opening exists, and that is a small one on the left side just behind the head.

Dissection. - Those wishing to study the structure of this class by making a careful dissection may use any of the salamanders, a large tadpole, or a frog, which can 
be easily killed by immersing a quarter of an hour in a half pint jar of water containing an ounce of one per cent chloretone or a quarter of an ounce of chloroform. A frog is preferable for this work. Before killing, its method of respiration and locomotion should be noted. Among the external features to be observed are the moist, smooth skin, the teeth in the upper jaw, the peculiar tongue, the two minute apertures, called external nares, at the tip of the nose, the two eyes, each with two eyelids of which the lower is the more movable, the circular tympanic membrane just back of the eye, and the webbed condition of the feet. The three parts of the fore limb are the arm, forearm, and hand, with the four digits corresponding to the four fingers of man. The thumb is scarcely large enough to be noted. The parts of the hind limb are the thigh, leg, and foot, with the five toes webbed together.

To study the internal features, cut off with the scissors the entire ventral wall of the abdomen, lay the frog on its back in a waxed-bottom dissecting pan containing enough water to cover the animal. Pin down the sides of the abdominal wall and identify the various organs by the use of the illustration and comparison with the same structures in a fish. If the animal is a male, the sexual glands will be two oval solid yellowish bodies near the kidneys. The delicate membrane supporting the intestine is the mesentery, which is a part of the peritoneum, the thin glistening membrane lining the body cavity and closely surrounding most of the organs. The heart of the amphibia is composed of a ventricle and two auricles in addition to a venous sac and an arterial trunk. The circulation of the blood may be observed under the microscope in the tail 
of a tadpole. To make one lie quiet on a glass slip with a cover glass over its tail, immerse it in the chloretone mixture (water one part and one per cent chloretone five parts) until completely unconscious. A drop of blood put on a clean glass slip and at once spread very thin by drawing the end of another glass slip lightly over it will show the oval nucleated red corpuscles characteristic of most of the vertebrates except mammals.

The brain with its ten pairs of nerves joining its ventral aspect may be seen by cutting away the roof and sides of the skull with a heavy knife. Any one wishing to study the skeleton can render the flesh easily removable by boiling the animal an hour or more, depending upon its age, in two quarts of water containing an ounce of soap cut into slices.

\section{I7. REPTILIA}

The reptiles are distinguished from the amphibians by the presence of scales and the fact that the young never breathe by gills. Only three orders inhabit this country. They are the Squamata (snakes and lizards), the Chelonia (turtles and tortoises), and the Crocodilia (crocodiles and alligators.

\section{Squamata: Lizards and Snakes}

The name of this order is derived from the Latin squama, a scale. The distinguishing feature of the group is the presence of horny epidermal scales covering the surface.

The Lizards. - More than eighty species of lizards are known in North America. They differ from the snakes 
in not having a forked tongue and in having eyelids and an external ear opening on either side of the head. 'The common lizard (Sceleporus undulatus) is widely distributed over the United States. The skinks or striped lizards are fast runners and abound in the central and southern portion of our country.

The chameleon (Anolis principalis) is the grass green lizard of the South, which is capable of changing its color

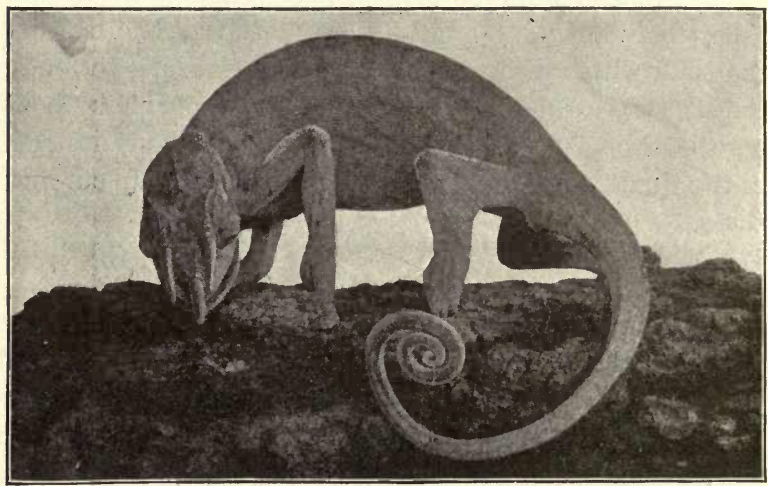

Fig. 243. - The horned chameleon from Africa. Photograph two thirds natural size.

to harmonize with its surroundings and thus escape the eyes of the enemy. The chameleon famed in literature is from Africa.

The glass snake (Ophisaurus ventralis), ranging from Wisconsin to Kansas and south, is remarkable for the complete absence of limbs. More than twenty species of limbless lizards are known. There are a dozen species with 
hind limbs only, and two or three species in which fore limbs only are present. The study of fossil reptiles shows that the ancestors of these forms had well-developed limbs which degenerated on account of the habits of the animals ; they spend much time in narrow quarters where legs are useless and a hindrance.

The only poisonous lizard in this country is the Gila monster (Heloderma suspectum) living in Arizona, Cali-

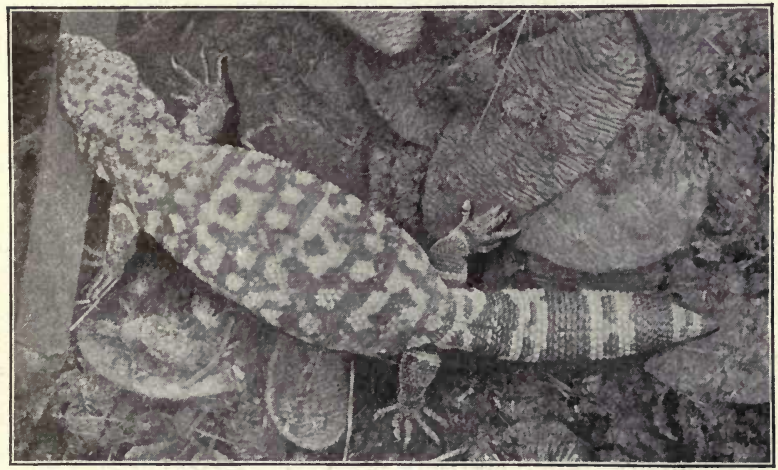

FIG. 244. - The Gila monster. Photograph one fifth natural size,

fornia, and Mexico. The largest specimens measure nearly a yard. Allied to these are the huge monitor lizards of Africa, India, and Australia, which attain a length of seven feet. Most lizards are oviparous, depositing their eggs in the sand.

The Ophidia. - The snakes, numbering one hundred and fifty species in North America, are much more elongated 
than the lizards, and with the exception of very few species possess no remnants of hind limbs.

The family Colubridoe includes most of our harmless snakes. The commonest of our garter snakes (Thamnophis sirtalis) frequents yards, gardens, and fields in search of mice, frogs, and insects. Like all snakes, they swallow

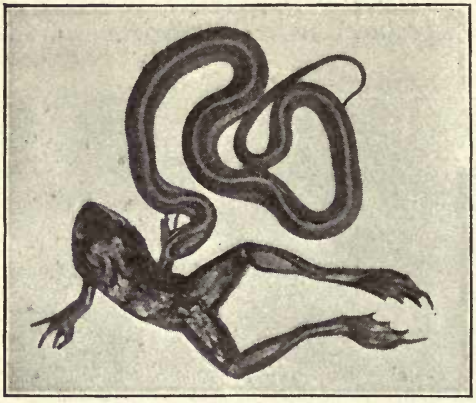

FiG. 245. - A garter snake two feet long and the frog which it swallowed. Photograph.

their prey whole and sometimes alive. The lower jaw is so loosely attached to the skull as to permit the throat to be greatly enlarged and the alimentary canal may likewise become much expanded owing to the fact that the ribs are not articulated to a breastbone, as in birds and mammals, but terminate freely. The prey after being swallowed may remain alive some time in the stomach. I once shot a water moccasin (Natrix sipedon) and upon opening the stomach an hour later found seven fish, three of which swam away when placed in water.

The milk snake or spotted adder (Lampropeltis triangularis) frequents the neighborhood of houses, and is often mistaken for the copperhead pilot. When disturbed it mimics the poisonous snakes, but is entirely harmless. The black snake or blue racer (Bascanion constrictor) frequents 


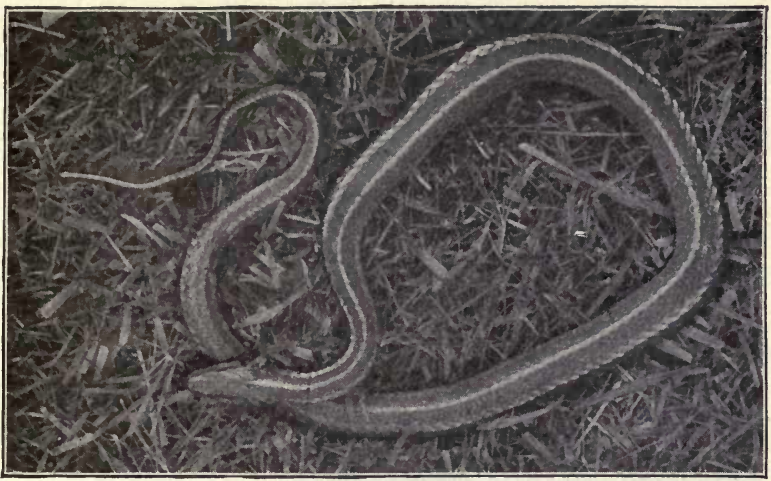

Fia. 246. - Thamnophis sirtalis three feet long. Photograph.

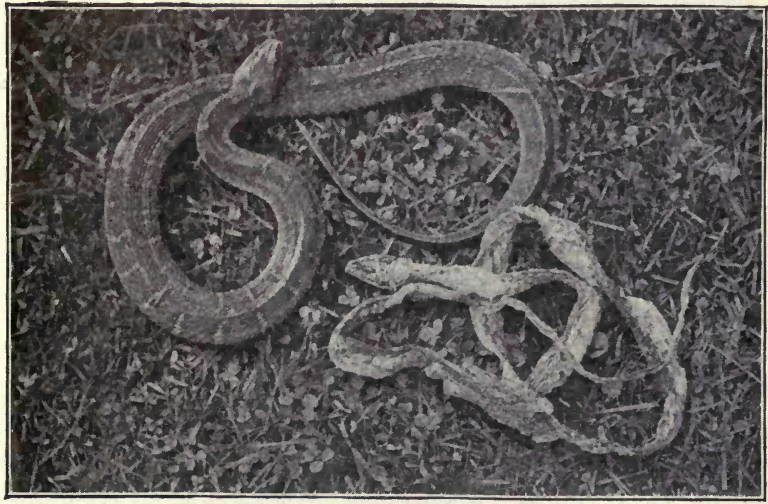

Fig. 247.- Water snake or moccasin often found along the streams. Three feet long. Below is the skin which it shed entire just before the photograph was made. 


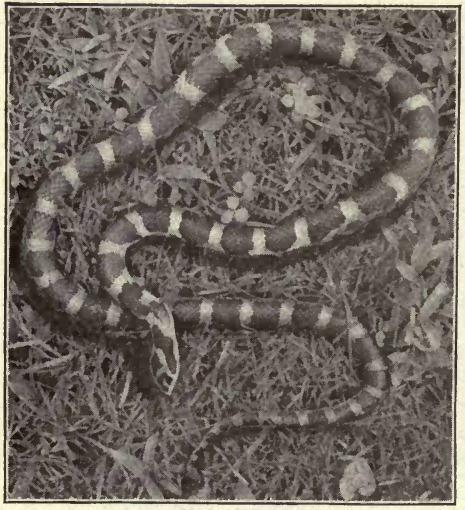

FIG. 248. - Spotted adder nearly three feet long. Photograph.

pasture grounds and woods east of the Mississippi, attains a length of seven feet, but is entirely harmless. It is fond of birds' eggs and birds which it often climbs trees to secure.

Crotalide is the family including all our poisonous snakes, except one species, the bead snake, ranging from Virginia to Arkansas and the

South. There are no external features which enable one to determine with certainty at sight whether any snake is venomous or harmless, but a flattened head, constricted neck, short tail, and pit in front of the eye give unmistakable evidence that the reptile is a venomous one. Two fangs perforated or

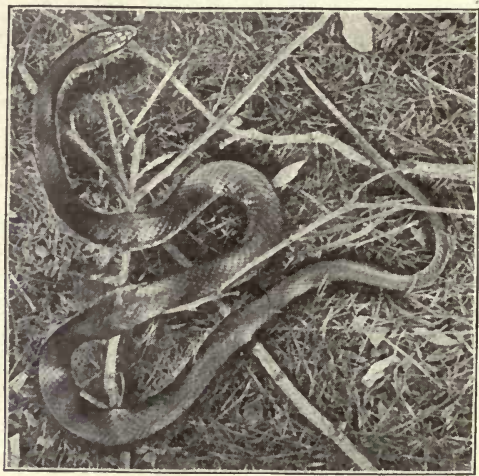

FIG. 249. - Black snake four feet long. Photograph. 
grooved are present in the front part of the upper jaw of all venomous snakes. The red forked tongue darted quickly back and forth is by many wrongly supposed to be the sting of the snake.

The only venomous serpents of our country are the rattlesnakes, copperhead pilot, cotton mouth or southern moccasin, harlequin, and coral or bead snake.

The rattlesnakes, which are not found outside of America, number about a dozen species in the United States. They are characterized by the possession of from three to fifteen horny buttons at the end of the tail. The number of these buttons or rattles does not tell the age of the reptile, as two or three are grown in a year, while one or more may be lost. The poison lying in

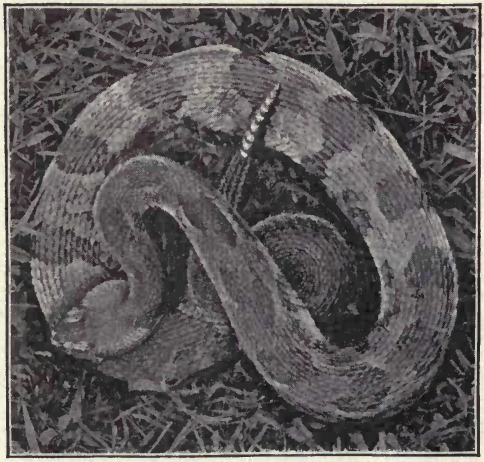

FIG. 250. - Rattlesnake three feet long coiled ready to strike. In this position it can dart its head forward two feet only. Photograph.

a sac just below each eye passes out through a duct leading through the center of the fang. The bite is usually fatal to man in from ten to fifteen hours, unless some remedy is used. A deep gash should be made with a knife so as to let the poisoned blood escape from the wound, and if in an extremity a tight bandage should be placed above it to prevent the poison from reaching the other 
parts of the system and paralyzing the nerves controlling the hesrt and lungs. Whiskey is useful to stimulate the latter organs and a large quantity of milk should be drunk

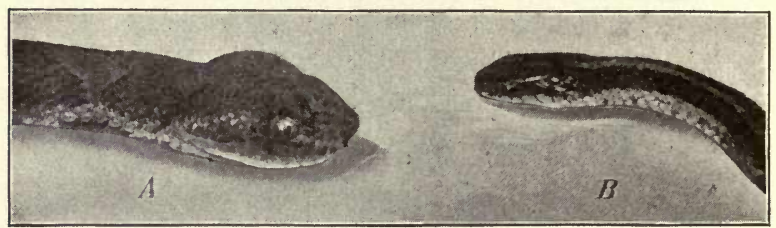

Fig. 251. $-A$, venomous snake (Copperhead); $B$, harmless snake. Photograph natural size.

until vomiting occurs several times. In the mean time a physician should be sent for to administer hypodermically

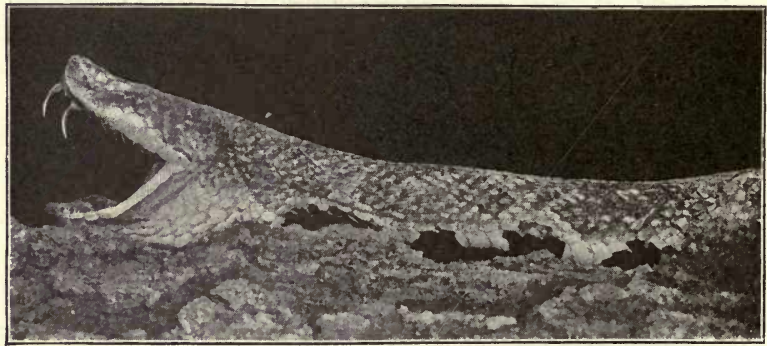

FIG. 252.-Copperhead with mouth open and fangs erected as when biting. Photograph natural size.

the proper antidotes, which are potassium permanganate or chromic acid in the proportion of one part of the chemical to one hundred parts of water.

The copperhead or pilot (Ancistrodon contortrix) is a 
dangerous reptile found in the Eastern and Central States in moist lands and near woodlands. The same treatment

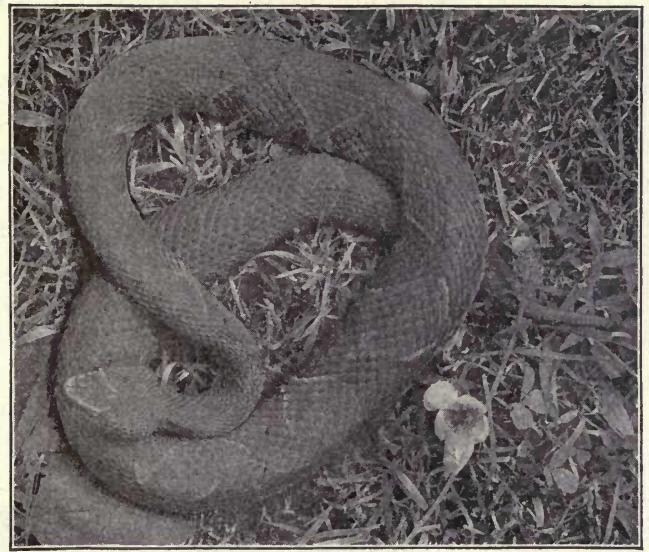

FIG. 253. - A copperhead three feet long. Photograph.

as that directed for the rattlesnake prevents the bite from resulting fatally.

The southern water mocassin (Ancistrodon piscivorous)

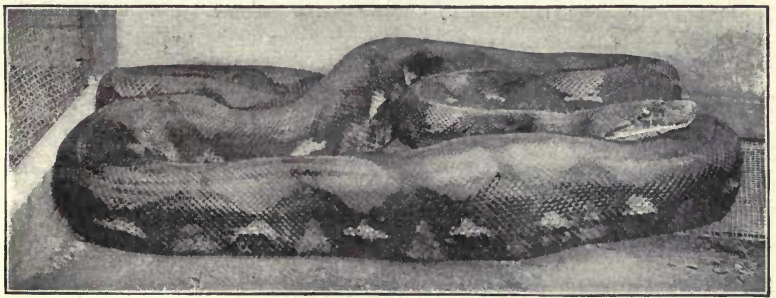

FIG. 254. - Photograph of the twenty-foot python in the Philadelphia Zoölogical Gardens. 
is a very venomous snake in the South, resting on bushes overhanging streams watching for its favorite food, con-

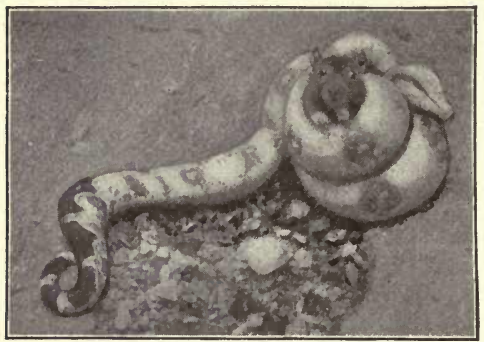

FIG. 255. - Boa constrictor crushing a rat preparatory to swallowing it. Photograph.

sisting of frogs and fish. The Cobra (Naja tripudians), attaining a length of four feet, is a deadly snake living in India where it is much feared because during the wet season it seeks protection in the huts of the natives. About twenty thousand people and several thousand cattle are killed annually by its bite.

The family Boidoe includes the largest of living snakes. They are non-venomousbut dangerous, owing to their ability to crush a deer or man by coiling about him. A peculiar feature exhibited

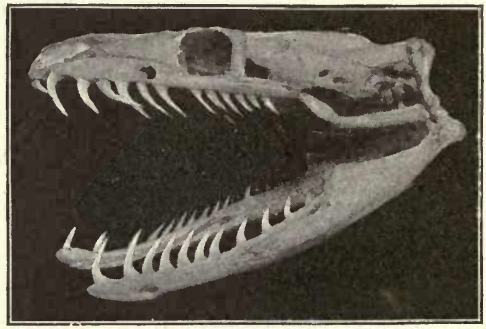

FrG. 256.-Skull of Boa constrictor two thirds natural size. Photograph. by them is the presence of rudimentary hind limbs. The Indian python attains a length of twenty-five feet and a diameter of ten inches. The Anaconda, inhabiting South America, is the largest of all snakes. Specimens have 
been seen more than thirty feet long. Among the true Boas, found in Madagasear and tropical America, the best known is the Boa constrictor of South America, about thirteen feet in length.

The epidermis or outer skin of snakes is shed two or three times a year and usually in a single piece. The young of some species, such as the rattlesnake and moccasin, are born alive, while others, such as the black snake, grass snake, and milk snake, are hatched from eggs deposited in the ground. Snakes pass the cold weather in a sleeping state beneath rocks and logs or in holes in the ground.

\section{Crocodilia}

The crocodiles are represented by only two species in this country: The Alligator Mississipiensis and Crocodilus acutus floridanus. Both dwell in the lowlands of the South.

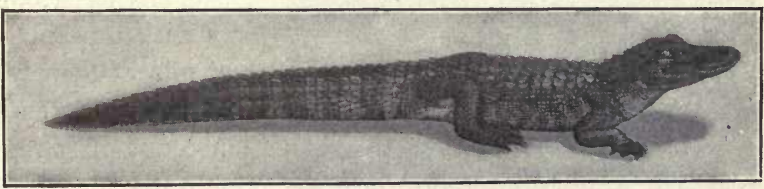

FIG. 257. - Photograph of a young alligator four feet long in the Philadelphia Zoölogical Gardens.

Their food consists largely of fish, but the larger alligators from ten to fifteen feet long sometimes attack mammals, dragging them into the water where they are drowned. There are about twenty species of crocodiles and alligators living in other countries. Some of them attain a length of twenty feet and are dangerous to man. 
The crocodilians reproduce by laying from thirty to sixty oblong white eggs as large as those of a hen, in a mound of muck, vegetable mold, or sand. Sufficient heat to hatch them is furnished by the sun and the fermentation in the decaying mound. The young of our species are more than six inches long when born.

\section{Chelonia or Testudinata: Tortoises and Turtles}

The members of this order are characterized by a more or less fully developed bony shell investing the body and by the absence of teeth.

They are widely distributed throughout the warmer regions of the globe, about fifty species being known in the

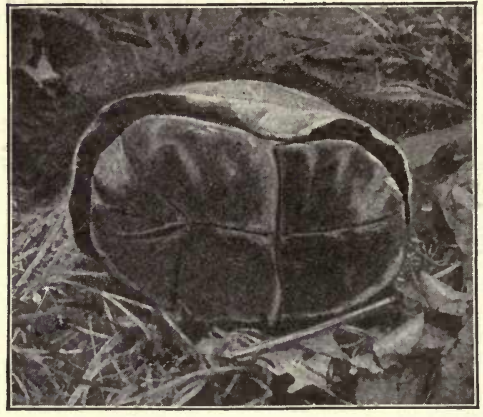

Fig. 258. - Box tortoise seen from beneath to show the hinge joint. One fifth natural size. Photograph by D. S. Hartline.
United States.

The name tortoise is applied to those forms having strong legs with unwebbed feet adapted to progression on land. The commonest representatives east of the Rocky Mountains are the box tortoise (Terrapene carolina) and the wood tortoise (Clemmys insculpta). In the box tortoise the dorsal shell, called carapace, is strongly arched and of variable colors, blackish and yellowish. 
The ventral shell, the plastron, has a transverse hinge near the middle. The wood tortoise has a keeled carapace, the plates of which are marked with concentric strix and radiating black bands. In the Gallapagos Islands very large tortoises are found, one of which, the elephant tortoise, attains a length of five feet and is able to carry a man.

The term terrapin is used to designate those tortoises having more or less of a web between the toes so that they are adapted to both terrestrial and aquatic life. The

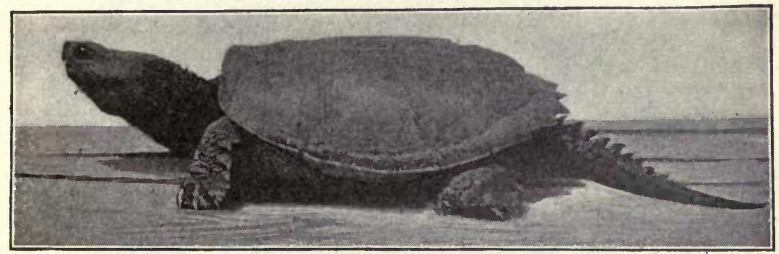

FIG. 259. - Snapping turtle or torup. Photograph by Overton.

painted terrapin (Chrysemis picta) is so called on account of the bright red markings on the margins of the shell. It is abundant everywhere along the ponds and streams of the eastern United States. Large numbers sit on the logs and the stones at the water's edge sunning themselves, and at the approach of any one glide into the water. Several species of terrapins are much prized for food. The snapping turtle (Chelydra serpentina), attaining a length of two feet, is common throughout most of North America. Soup made from it is greatly in demand. It is a fierce carnivorous reptile feeding on ducks, chickens, frogs, and other aquatic animals. 
The true turtles differ from the tortoises in having limbs flattened for swimming and only two of the toes bearing claws. They dwell in the ocean and only come to shore for the purpose of depositing their eggs in the sand to

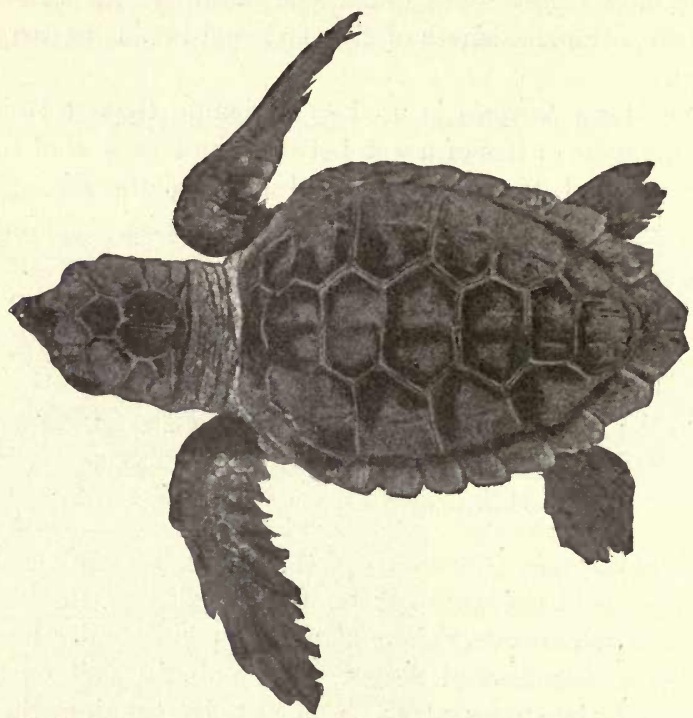

FrG. 260. - Loggerhead turtle one week old. Photograph about natural size.

hatch. The green turtle is the source of the far-famed turtle soup. The loggerhead turtle of Florida and the West Indies resembles the green turtle, but is less prized for food. The tortoise shell of commerce is derived from the hawkbill turtle (Chelone imbricata) which is more than two feet in length. 
All chelonians are similar in their habits and structure. The eggs varying in number from five to more than one hundred are deposited in the ground. They may be distinguished from those of snakes by the fact that they are nearly spherical. The period during which the eggs are incubated by the heat of the sun va:ies in different species from one to four months. The land chelonians pass the cold weather in a dormant state under logs and stones or in self-constructed burrows in the earth, while the terrapins and turtles bury themselves in the mud.

\section{Dinosauria: Giant Lizards}

The Dinosauria form an order of extinct land reptiles which inhabited the earth more than ten millions of years

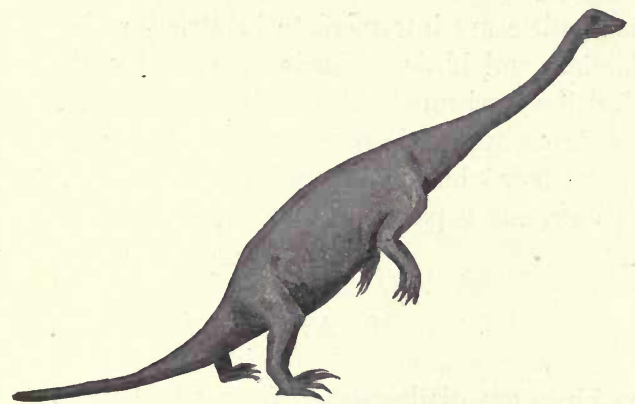

FIG. 261. - Dinosaur three feet long, restored from a study of the skeleton found in Connecticut.

ago. All that is known of them has been learned from the study of their fossil remains found in the rocks of Europe, India, South Africa, and North America. All had limbs, 
and in many species the hind ones were much larger than the front ones, indicating that the animals walked on two legs similar to the birds. The bones are hollow, as in birds, and since in several other important features the skeleton is similar to that of birds it is believed that the two groups are closely related and have descended from a common parent. Many species were of immense size. Brontosaurus, the giant reptile whose mounted stone skeleton is in the Museum of Natural History in New York, was over sixty feet long. Diplodocus, whose fossil remains may be seen in the Carnegie Museum of Pittsburg, was about seventy feet in length. The extinction of this entire group of huge creatures may have been brought about by lack of food or the presence of numerous parasitic or carnivorous enemies.

The reptiles are intermediate in structure between the amphibians and birds. The brain resembles that of the frog, but the cerebrum is larger. The vascular and respiratory systems approach the condition in birds. In most forms the heart has two auricles and one ventricle; but in the crocodile a partition divides the ventricle into two parts.

\section{AVES}

The birds are distinguished from all other vertebrates by the presence of feathers. The two anterior limbs are modified into the form of wings adapted for flying or swimming. They differ from the three preceding classes in being warm-blooded, having a temperature of from one hundred and two to one hundred and nine degrees. As an 
assistance to flight most birds are able to decrease the specific gravity of the body by means of a series of air sacs communicating with the lungs. The larger sacs, usually about a dozen in number, lie in the trunk region, but smaller ones sometimes occur in the bones, which are hollow in. stead of being filled with marrow as in the mammals. All birds are oviparous (lay eggs), some species depositing as many as two hundred eggs in a season, while others lay only one each year.

No modern bird possesses any teeth, but the fossil remains from Kansas show that the birds living millions of years ago had sharp, reptile-like teeth. The most ancient bird known is Archoeopteryx, about the size of a crow. It possessed a long, jointed tail, numerous sharp, conical teeth, claws on the wing, and many other reptilian characteristics. These facts indicate that the birds have descended from a reptile-like ancestor.

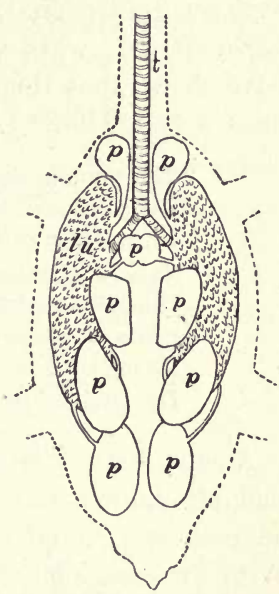

Fic. 262.-Diagram of the lungs and air sacs of a pigeon. $p$, air sacs; $l u$, lung ; $t$, trachea.

Within the history of man a number of species of Aves have become extinct, and reports from nearly every state show that unless quick and effective protection is afforded our feathered friends, irreparable damage may result to the country. Special investigations made by Hornaday show that the average decrease in bird life throughout the United States from 1883-1898 was forty-six per cent. 
Reports from Maine, Rhode Island, Pennsylvania, Indiana, North Dakota, Georgia, Louisiana, and Texas stated that more than half their birds had disappeared, while observers from Connecticut, Florida, and Montana agreed that the numbers of birds in those states had decreased by seventyfive per cent. The seriousness of these facts becomes apparent only when we realize that recent investigations have shown that there is as much truth as poetry in the lines of Longfellow*

"The summer came and all the birds were dead;

The days were like hot coals; the very ground

Was burned to ashes; in the orchards fed

Myriads of caterpillars, and around

The cultivated fields and garden beds

Hosts of devouring insects crawled, and found

No foe to check their march till they had made

The land a desert without leaf or shade."

A careful study of the birds emphasizes the necessity of making children familiar with their value, not only from an economic standpoint, but also from an wsthetic view. With the exception of the English sparrow, the cow bird, two species of hawks, and the great horned owl, all birds of our country are man's friends.

There are about thirteen thousand species of birds in the world, but not more than eight hundred species occur in the United States, and seldom is any one locality favored with more than two hundred kinds. But few lovers of nature can expect to become familiar with more than fifty species in one region. The identification of birds, especially the warblers, vireos, and sparrows, in the bush or on the wing, is not an easy task, but if the beginner proceeds 
patiently and systematically he will be able to acquaint himself with a score or more of birds during any summer month. When a new bird is seen, the observer should write an accurate description of it in his notebook, giving the length from the tip of the bill to the end of the tail; the color of the crown and sides of the head, back, wings, tail, breast, and belly; length, shape, and color of the bill;

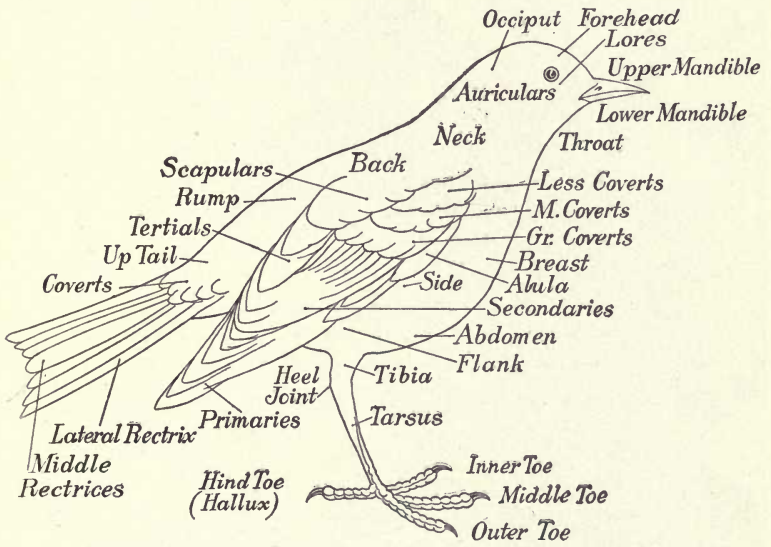

FIG. 263. - Names used in describing a bird. Drawing by Reese.

length, position, and arrangement of the tail feathers; and the method of feeding and manner of flight as well as its characteristic song. Such a record will enable one to identify the stranger by comparison with the descriptions given in such books as "Bird Neighbors" or Chapman's "Bird Life." The brief descriptions and illustrations in the following pages will help the pupil to determine the names of some species. 


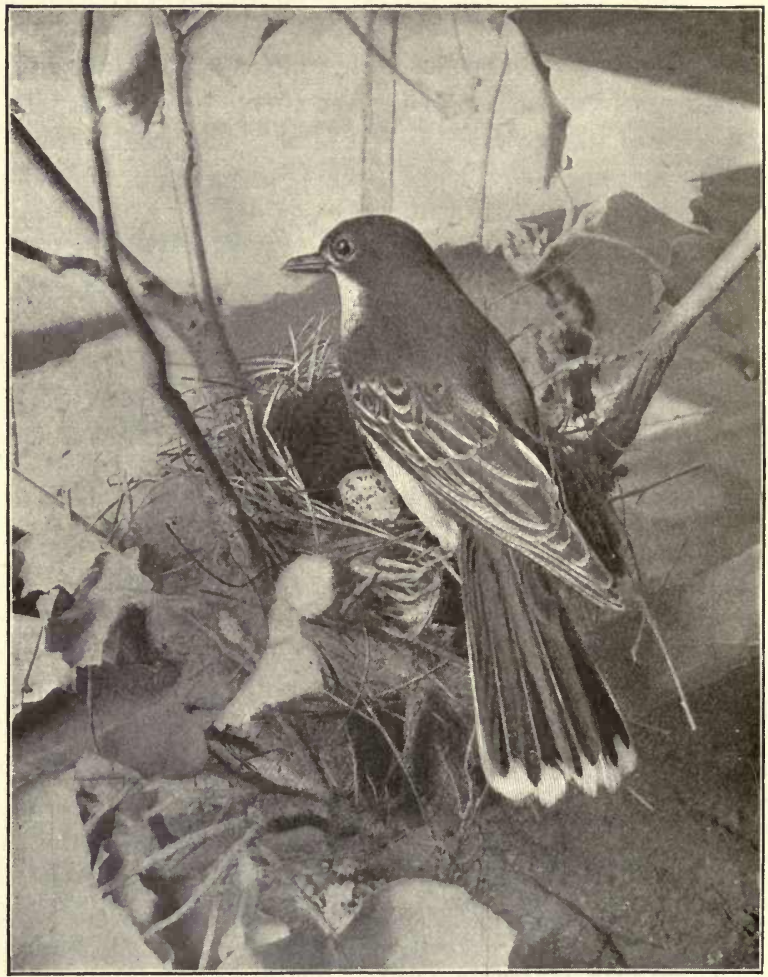

FIG. 264. - Kingbird at its nest. Photographed in the Museum of Natural History, New York. One third natural size. 
The birds are grouped into about twenty orders, of which only the eight most important ones will be discussed.

\section{Passeres: Perching Birds}

This order includes approximately one half of our species. They may be recognized by the presence of four unwebbed toes all on the same level and with joints in number 2,3 , 4,5 , respectively from the first (inner) toe to the fourth (hind). All our song birds belong to this group, of which the families here given have representatives in most localities.

Flycatchers (Tyrannidæ). - The members of this family

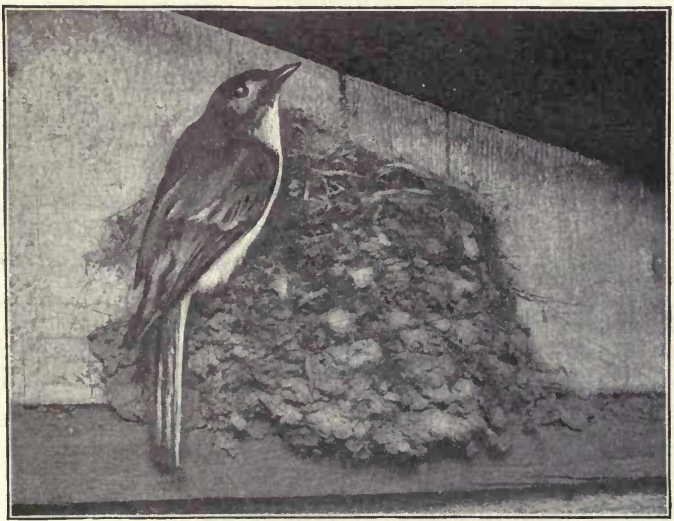

FIG. 265. - Phobe with its mud nest in the corner of an old boathouse. Photographed in the Academy of Natural Sciences, Philadelphia. One third natural size.

are so named because they feed largely on aerial insects which they seize in flight. Hornaday says every flycatcher 


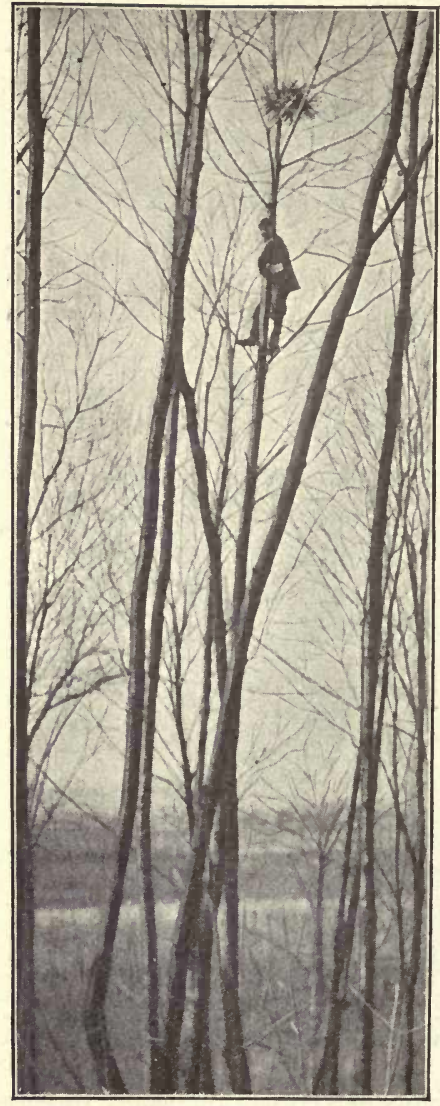

FIG. 266. - Hunting crows' eggs in March. Photograph by Neal. is worth double its weight in silver to the farmers. The kingbird or bee martin, recognized by its white-tipped black tail, was once thought to be a destroyer of bees, but late investigations show that it eats very few bees and most of these are drones. Ninety per cent of its food consists of harmful insects. It nests in trees in the orchard or forest margin. It migrates south in winter. The Phobe or pewee is a trifle larger than the English sparrow and reveals its presence by its characteristic note, pewit, pewee, phœbe, phœbe. It arrives from the south in March, and acts as special police to the agricultural interests 


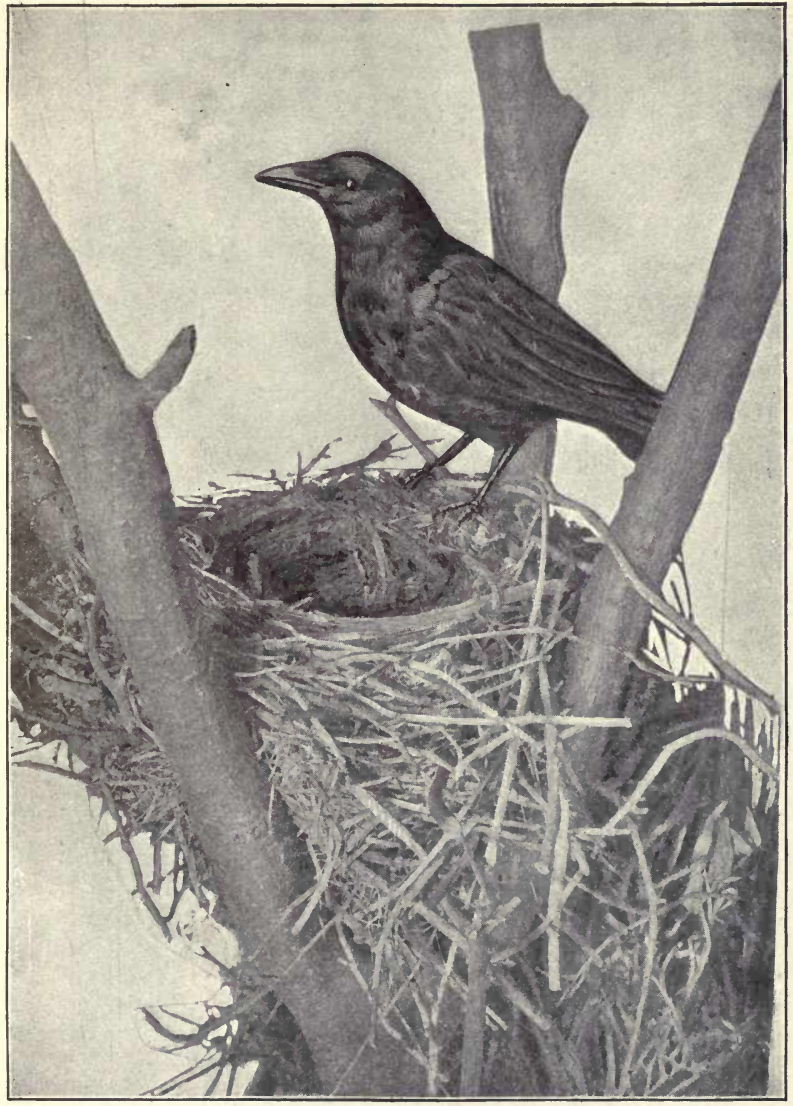

FIG. 267. - Crow and nest, one tenth natural size. Photographed in the Academy of Natural Sciences, Philadelphia. 


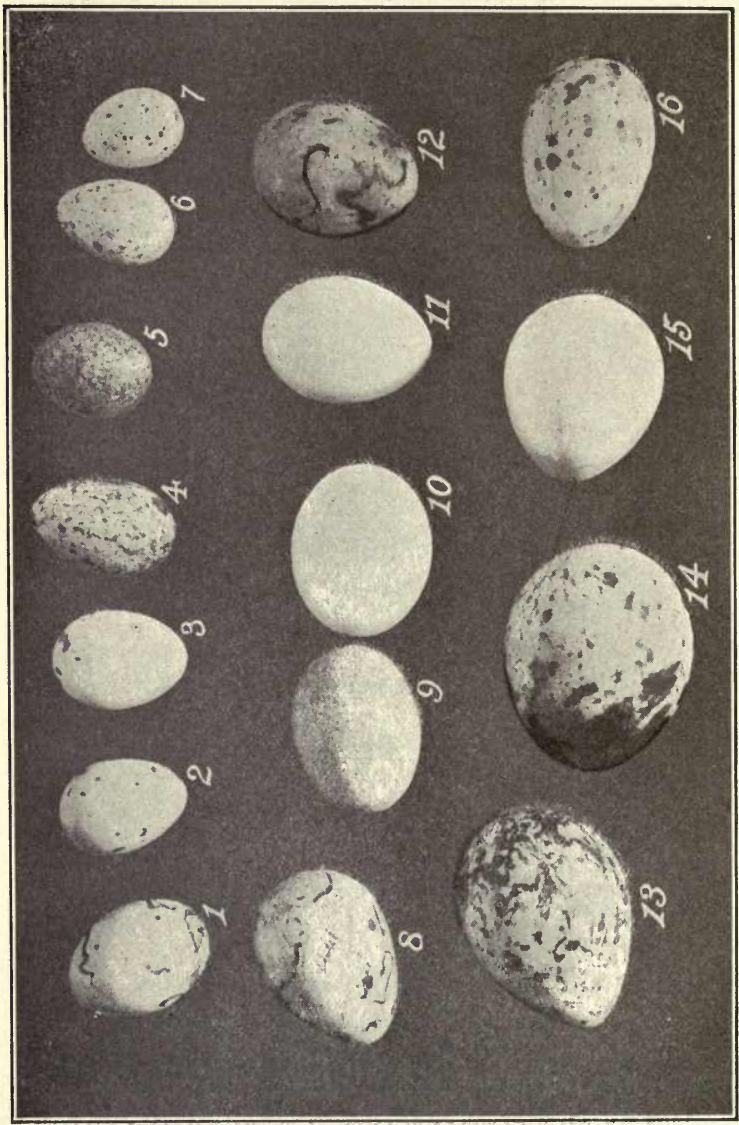

bo …

동농 농 15 卷 횽 \$ 8 를

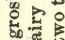
कृ I… 냉오

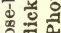
당 A +요. …… 얼 눙 요요 क ㅇ.. 콩 또 ㄴํำ 푸 $\triangleq$ … ๑ का 3

... 5 응 은 章 10 究 … ○ 蚂 ㄱํㄹ ... ․․․ 응 ○ 5 맹 흥 हु ड़ 密 …임 $\dot{n} \equiv$

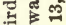
2 $\infty$... 능 폭 电 की I $\ddot{0}$ कृ ○。 5 
throughout the summer, when more than nine tenths of its food consists of insects and spiders.

Crows (Corvidæ). - The crows, jays, and ravens are not worthy of much encouragement. The common crow, although destroying young corn and eating the eggs and the young of other birds, atones for his evil deeds by destroying large numbers of mice and cutworms. The magpie west of the Rocky Mountains sometimes attacks horses and mules where the flesh has been lacerated by the harness.

Orioles and Blackbirds (Icteridæ). - The Baltimore oriole often called golden robin or firebird should be familiar to every one in eastern North America. The male arriving from the south when the orchards are in blossom may be recognized by its glossy black head, throat, wings, and upper back, and the rich orange color of the other portions of the body. It is a trifle smaller and not so stout as the common robin. The female is of a yellowish olive color. The nest is an exquisitely woven pouch swung from a high limb.

The five or six young during their ten days of life in the nest consume thousands of noxious caterpillars and canker worms, of which species the parents are also fond. Beal states that caterpillars formed thirty-four per cent of the food of one hundred and thirteen specimens examined.

The bobolink, a country dweller in eastern North America all summer, assists the farmer in destroying insects, but later in the season retiring southward it creates havoc in the rice fields and is known as the rice bird. When sold in the market it is called reed bird. This species is an exemplification of the great difference that may exist between 
the plumage of the two sexes as well as the variation in the plumage in different seasons. The black and white male presents a strong contrast to the dull yellowish-brown female. In autumn, however, the plumage of the male changes to the same hue as that of his partner.

The cow bird never builds a nest, but lays its brownspeckled white eggs in the nest of a smaller bird where hatching more quickly and growing more rapidly than the rightful occupants, they crowd the latter out of the nest. It is nearly as large as the robin, but not so stout. The dusky brown female is smaller than the male which has an iridescent black head. They often mingle with the cows in the pasture.

The meadow lark, widely distributed over the United States, is a lover of the pastures and meadows, where it may be recognized by its white tail feathers and large black crescent on a yellow breast. It is larger than the robin. The stomach contents of ninety-three specimens show that it is of great value in ridding the grass lands of insects. The blackbirds, the larger of which are called grackles, sometimes pull up the young corn, but they make ample restitution by destroying weevils, grubs, and army worms. The red-winged blackbirds nest in bushes in the swamps, and the grackles build in the tree tops.

Finches (Fringillidæ). - This family includes many small birds and a few larger ones, among which is the rosebreasted grosbeak, famous for its soft, sweet, rolling warble on moonlight nights. The large beak and the rosy breast of the male gave origin to the name.

The sparrows, of which there are more than a score of species residing with us, are with one exception exceedingly 


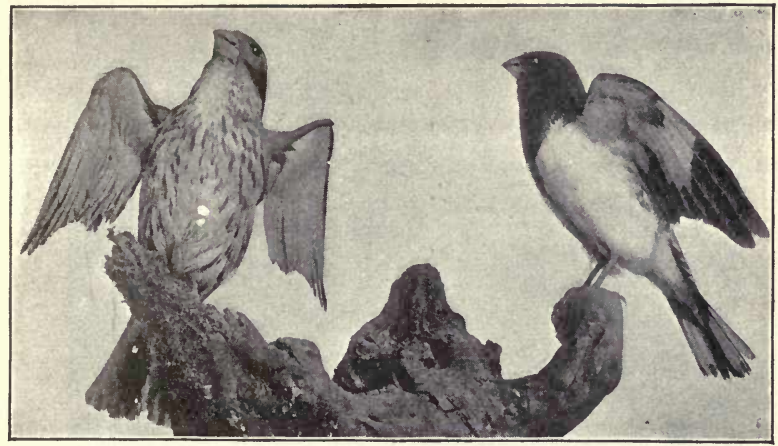

FiG. 269. - Rose-breasted grosbeak. Female on the left and male on the right. Photograph one fourth natural size.

beneficial birds, consuming large quantities of noxious weed seeds and destructive insects.

The English sparrow (Passer domesticus) was imported

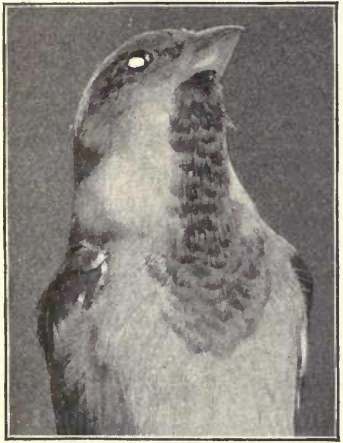

Fig. 270. - Male English sparrow. from England into this country in 1850, and as it rears four or five broods of from four to six young each season, the whole country has become infested with the species. The male is easily recognized by its black throat and breast. In many localities this is the only sparrow seen in winter. It destroys not only buds and blossoms but attacks grapes, berries, tomatoes, and other fruits, in addition to consum- 
ing large quantities of grain and being guilty of driving away the song birds, whose nests it robs. An examination of five hundred and twenty-two stomachs made by the Department of Agriculture showed that over three fourths of the birds had eaten no insects whatever, while the others

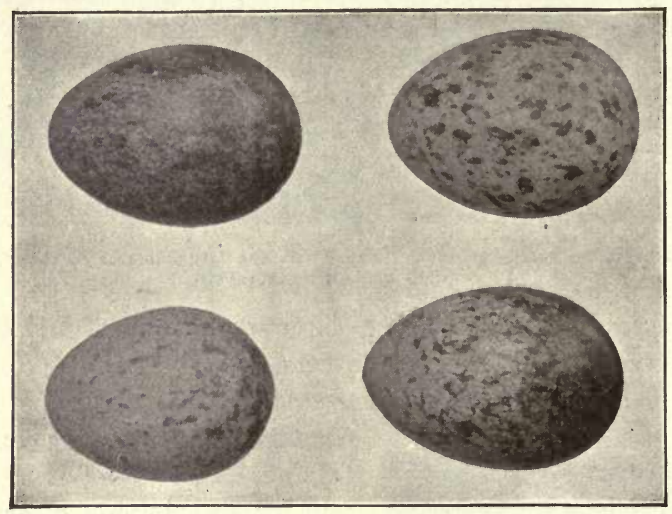

FIG. 271. - Eggs of the English sparrow showing variation in color. Photograph natural size.

had devoured but few insects, most of which were beneficia! ones. The nests, untidily built of hay, stems, and feathers, in clinging vines and trees, should be destroyed.

The chipping sparrow, called chippy or hair bird, is distinguished from the English sparrow by a gray stripe over the eye and a blackish-brown one apparently through it. The value of this bird, rearing two broods each season, is shown by Weed and Dearborn, who watched the parent birds come to the nest almost two hundred times in one day, 


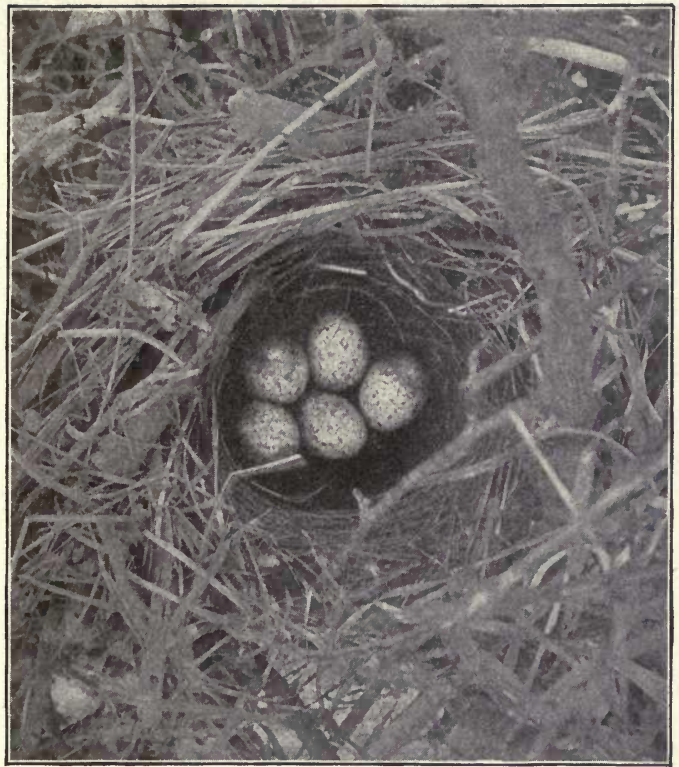

Fia. 272. - Nest of a song sparrow in a currant bush. Photograph half natural size.

bringing caterpillars, grasshoppers, and other insects for the young. Forty per cent of the food of the adult consists of insects. The song sparrow differs from the two preceding in having the ventral portion of the body gray shading to white and heavily streaked with darkest brown.

The vesper sparrow is easily identified by the partially white outer tail quills very conspicuous in flight. Its nest 


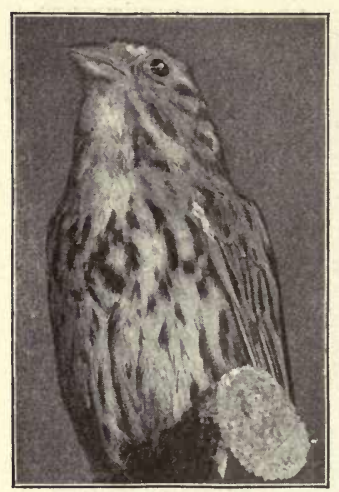

FrG. 273. - Song sparrow.

is built on the ground but not lined with hair like the song sparrow's, which sometimes is found in a bush.

Swallows (Hirundinidæ). The swallows are characterized by a forked tail. They are valuable insectivorous birls, seizing their food on the wing. The cliff swallows and barn swallows are the commonest summer species in eastern United States. The bank swallow rears its young in holes excavated to the depth of two feet in a sand bank.

The Chatterers (Ampelidæ). - This family is well represented by the cedar bird, famous for its raids on insects. Seven stomachs examined averaged over one hundred canker worms each.

The Vireos (Vireonidæ). - The vireos are olivaceous birds, more slender than the English sparrow. The redeyed and white-eyed are common. The nest is easily recognized by the fact that it has the shape of the lower half of a teacup and is constructed in the crotch of a small horizontal limb without any support underneath. During the locust pest in Nebraska four fifths of the food of the red-eyed vireo consisted of these insects.

Wrens and Mocking Birds (Troglodytidæ). - The catbird and house wren are the best known members of this family. The latter is the most valuable of all birds in 


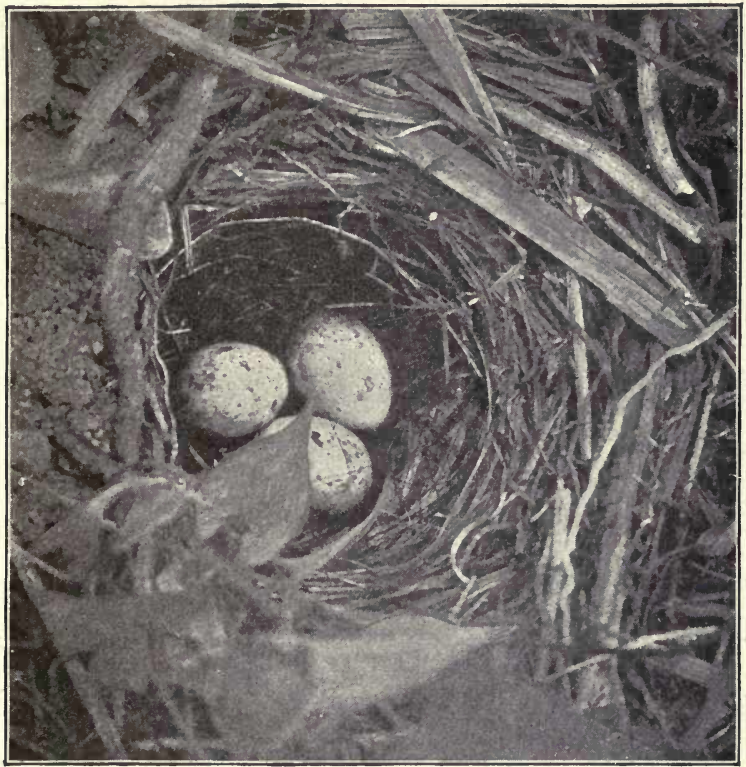

FIG. 274. - Nest of a chipping sparrow on the ground in a wheat field. Photograph two thirds natural size.

destroying insects, and should be coaxed about our yards by nailing up boxes in which it may nest. The entrance to a box must not be more than an inch in diameter, as otherwise the English sparrow would preëmpt the home. A study of fifty-two wrens showed that ninety-eight per cent of their food was of insects.

Nuthatches and Titmouse (Paridæ). - This is one of the few families of birds remaining in middle and northern 


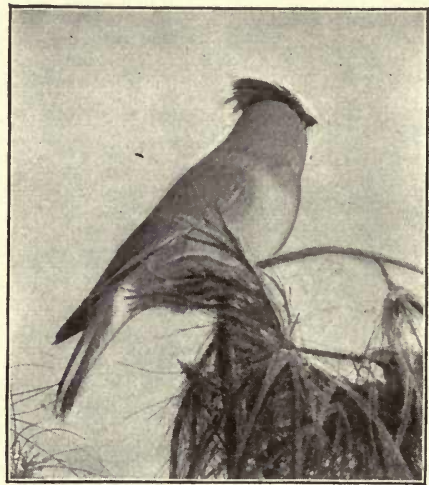

Fir. 275. - Cedar bird one third life size. Photographed in Academy of Natural Sciences.

United States throughout the winter. The white-breasted nuthatch seeks its food running up and down the trees in summer and feeds on seeds in winter. The black-capped chickadee or titmouse may be identified by its black crown and throat. According to recent investigations if we could persuade enough of these birds to dwell with us, the plant lice pest, costing millions of dollars annually, would be at an end. Over five thousand eggs of plant lice have been found in the stomach of one chickadee. Eggs of other injurious insects, as well as the adults, are also eaten in large numbers.

Thrushes (Turdidæ). - The robin is by many wrongfully considered a harmful bird on account of the cherries 
and berries taken. The large number of cutworms, grasshoppers, and beetles eaten more than compensates for the little fruit taken. Six robins shot in Nebraska contained two hundred and sixty-five Rocky Mountain locusts and eighty-four other insects.

The wood thrush (Turdus mustelinus) adds much to the charm of the woodlands in eastern United States by the melody of its liquid, flute-like note. It remains in the North during the summer

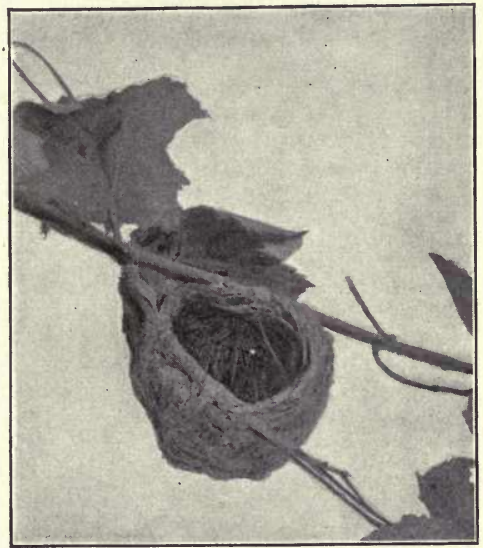

Fig. 277. - Nest of a vireo. Photograph one fourth natural size. only, while its relative, the bluebird, a voracious insect eater, dwells throughout the year in the latitude of New York and southward. Meat bones hung in the trees in winter and small boxes with inch and a quarter entrances nailed up ten feet above the ground for homes in summer will do much toward attracting this valuable and beautiful blue-backed gem about the yard.

It is estimated that a brood of five young during their thirteen days of home life will consume over one thousand harmful insects, and more than half of the parents' food consists of these injurious creatures. 


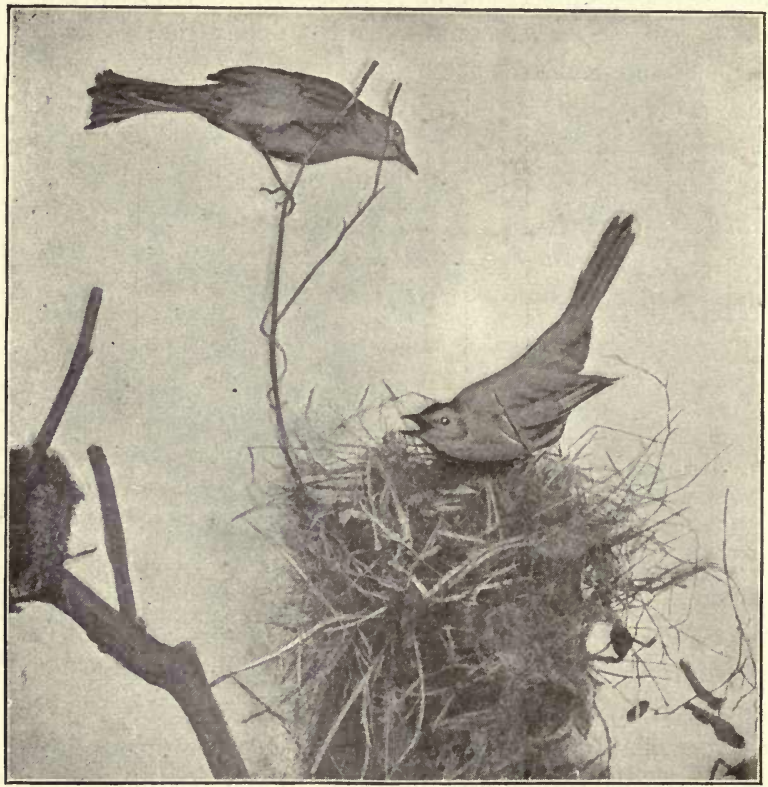

FIG. 278. - Catbirds and nest. Photographed in the Academy of Natural Sciences, Philadelphia.

\section{Humming Birds and Swifts (Macrochires)}

This order includes the smallest of birds and also a few larger species. The most notable member is the rubythroated humming-bird feeding on the nectar of flowers, sap of trees, and insects. The chimney swift, building its nest of sticks glued together with saliva, and fixed to the chim- 
ney or inside of deserted buildings, seizes its insect food in flight, asdoalso the whippoor-will and nighthawk, coming forth at eventide from their forest retreats.

\section{Woodpeckers} (Pici)

This order is composed of ar-

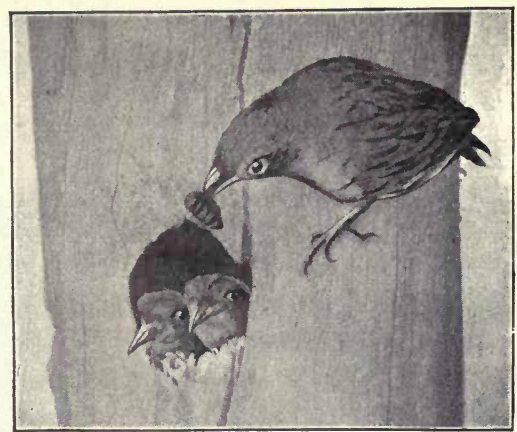

Fig. 279. - Wren with food for her young. Photographed in the Academy of Natural Sciences. One third life size. boreal birds, all of which with one exception, the sapsucker,

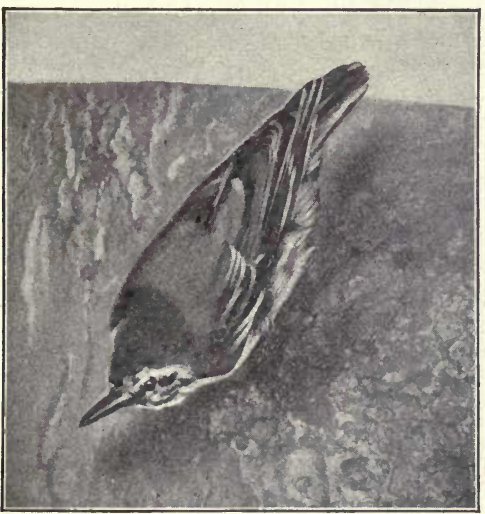

FIG. 280.-White-breasted nuthatch photographed in the Academy of Natural Sciences. One third life size. are preëminently insectivorous birds. They may be recognized by their habits of picking small holes in the bark of trees to secure the bark beetles and larvæ of other injurious beetles which damage the forest trees to the extent of several millions of dullars annually. The largest of the 
woodpeckers common near civilization is the flicker or high-holer, also called yellow-hammer, easily distinguished by the black crescent on the breast and the white rump conspicuous in flight. It feeds largely on ants. The

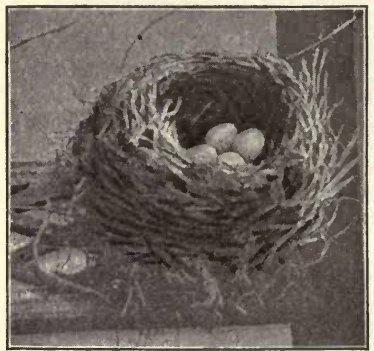

FIG. 281. $-A$.

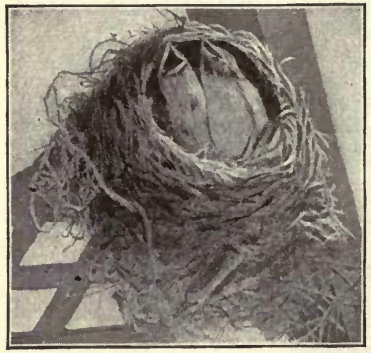

FIG. 281. $-C$.

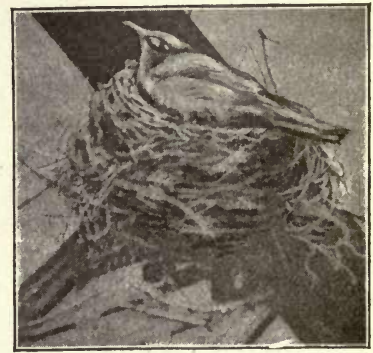

FIG. 281. - B.

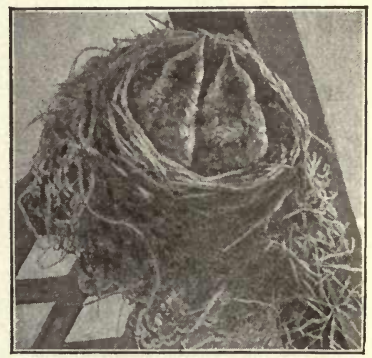

Frg. 281. $-D$.

FrG. 281. - The robin demonstrating how quickly hated insects inay be transforıned into grace and beauty. $A$ and $B$, May first ; $C$, May ninth ; $D$, May fourteenth ; $\boldsymbol{E}$ (page 247), May seventeenth, the day on which they flew away. Photograph by N. F. Davis. 
hairy woodpecker and the downy woodpecker, very similar in appearance, are the ones seen about lawns and parks. The red-headed woodpecker nesting in the hollow of telegraph poles ' and trees is common in many regions.

\section{Cuckoos (Coccyges)}

This order is represented

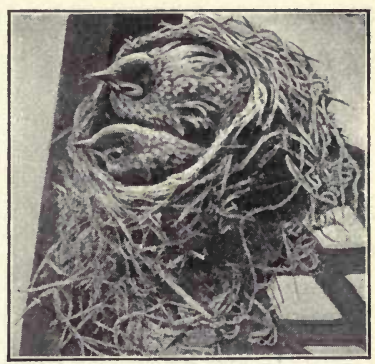

FIG. 281: $-E$. throughout eastern North America by the black-billed and yellow-billed cuckoos, sometimes called rain crows.

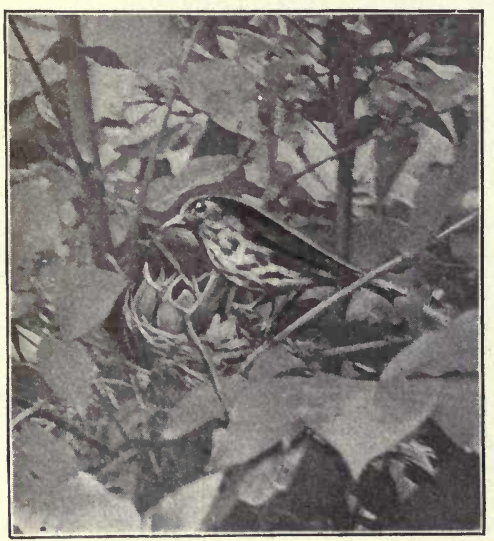

Frg. 282. - The wood thrush at her nest. One fifth life size. Photograph by N. F. Daviș.
They are valuable summer residents among the shrubbery and in the orchards and woods where they devour great quantities of hairy caterpillars and other insects. During May and June, tent caterpillars constitute about half their fare. The belted kingfisher, common in most parts of our coun- 
try, is one of the few birds living on fish. It nests in deep holes at the water's edge.

Hawks, Owls, and Eagles (Raptores)

The members of this order are called birds of prey, although many of them feed largely on insects and are therefore beneficial. They are characterized by a

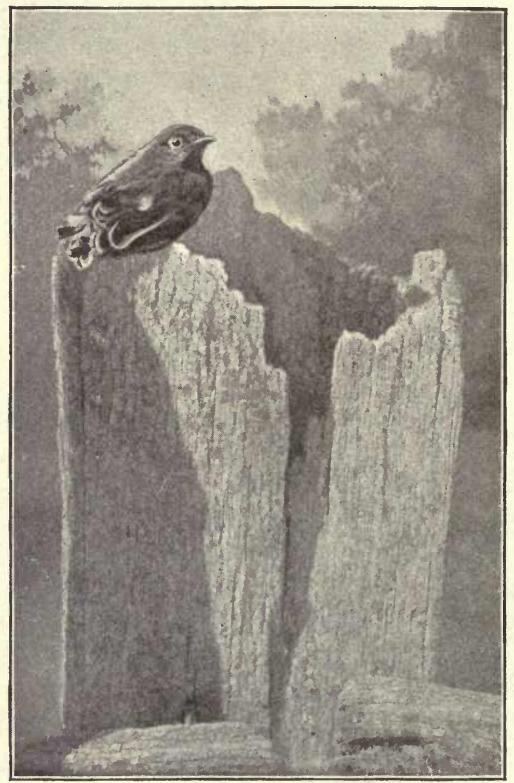

FIG. 283. - Young bluebird two weeks old just ready to fly. 'Two broods are hatched yearly in the cavity of this old fence post. Photograph one sixth life size. 
strongly hooked bill and curved claws, called talons, adapted for seizing and tearing flesh. Some of thein are of large size, such as the condor of South America and the California vulture, which are the largest birds of flight in the world.

Hawks and Eagles (F a lconid $æ$ ). Twenty years ago

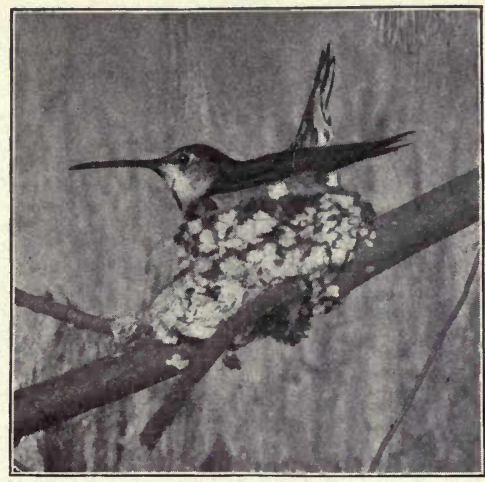

Fig. 284.- Ruby-throated humming bird on its nest. Photographed in the Academy of Natural Sciences, Philadelphia. Half life size. the hawks were thought to be man's enemies, and bounties were offered in "some states for their scalps, resulting in

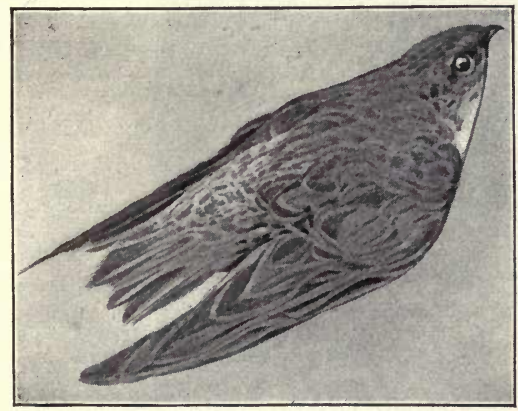

FIG. 285.-Chimney swift photographed from life. One third natural size. the paying out of many thousands of dollars for the killing of birds protecting the agricultural interests, upon which the success of the nation depends. They feed largely on rats, mice, and other destructive creatures, Owing 


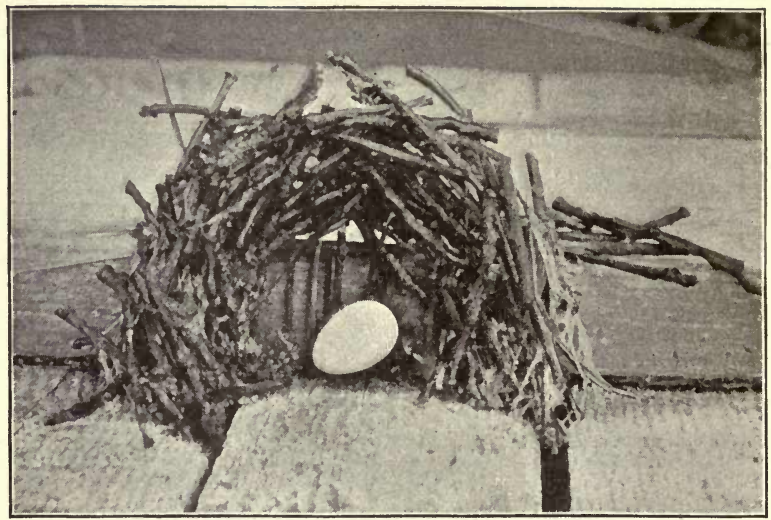

FIG. 286. - Nest of a chimney swift built in a barn. Photograph one third natural size.

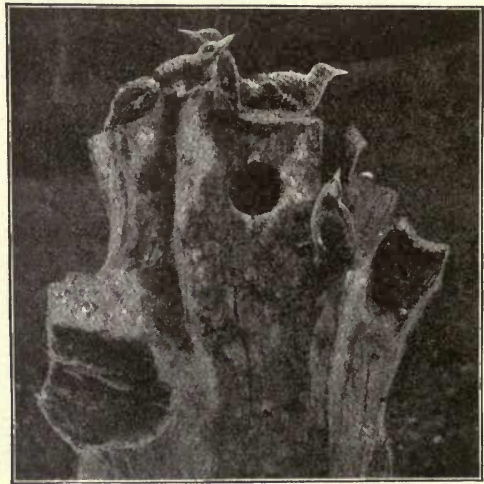

FIG. 287. - Flickers ready for their first flight. The hole is the door to their home. One tenth life size. Photographed by Jessie Wẹllş. 
to information lately furnished the lawmakers by the zoölogists, laws have been passed in many states protecting all hawks except the goshawk, Cooper's hawk, and the sharp-shinned hawk, which feed largely on song birds and poultry. The sparrow hawk occasionally destroys a few

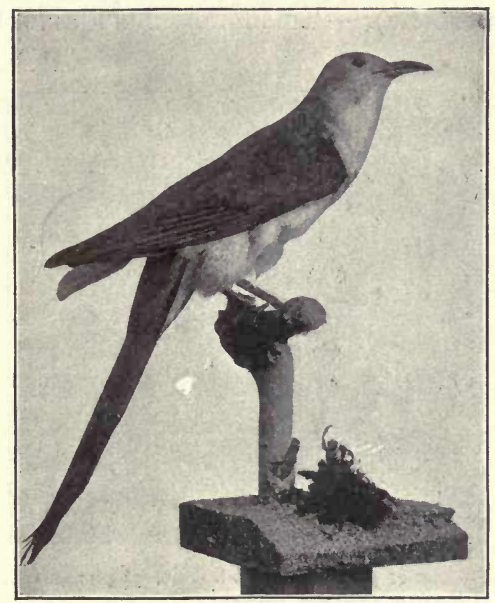

FIG. 288. - Black-billed cuckoo. Photograph one third life size.

song birds, but atones for it by preying on the worthless English sparrows and grasshoppers. Of one hundred and seventy stomachs of the red-tailed hawk examined, one hundred and thirty-one contained mice, nine contained rabbits and squirrels, six had snakes and insects, and in only four was any poultry present; nevertheless, this valuable bird is popularly referred to as the hen hawk. 
Only two species of eagles dwell in our land. The bald eagle, after attaining the age of three years, is distinguished from the golden eagle by its white-feathered head to which the name is due. The golden eagle has been known to destroy lambs and young deer, but the bald eagle is less fierce, and neither has ever been known to attack children.

Owls (Bubonidæ). - This family includes all the owls of

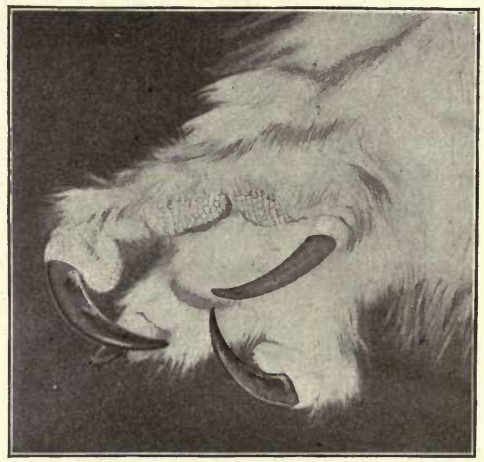

FiG. 289. - Foot of great horned owl. Photograph half natural size.

North America except the barn owl. With few exceptions they are nocturnal birds, living largely on mice, gophers, frogs, snakes, and rabbits. They have a strange habit of regurgitating out of the mouth in the form of small pellets such indigestible portions of the food as hair and bones. An examination of these pellets shows the kinds of animals upon which the bird has fed. It has thus been found that all of the owls with the exception of the great horned owl 
are beneficial to the farmer. The screech owl and the long-eared owl, so called on account of the tuft of feathers near each ear, are widely distributed over the United

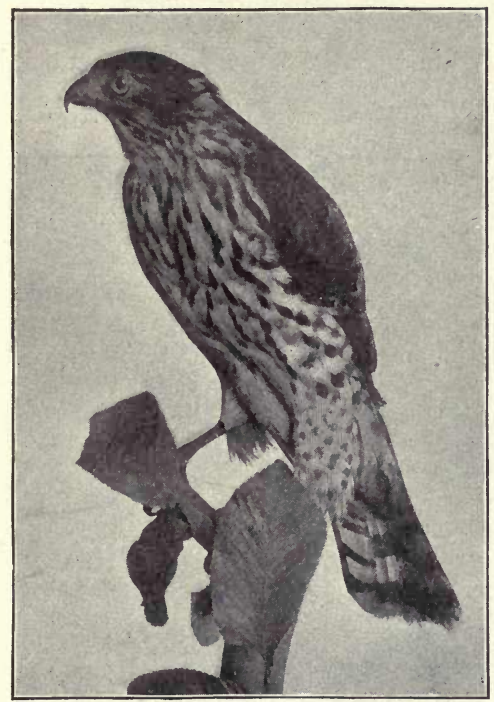

FIG. 290. - Cooper's hawk or chicken hawk eighteen inches long. Photograph of a mount by Neal of Easton.

States. Pellets from four of the latter species showed that in fifty-nine days they had consumed three hundred and forty-six mice, which if left unmolested would have consumed many dollars' worth of the farmers' produce.

The order Gallino, including the much prized game birds, 
partridge, grouse, and turkey, and the order Columbre, composed of the doves, will not be discussed, as their representatives are scarce in most localities.

\section{The Herons (Herodiones)}

This order includes the herons, storks, and ibises, which have long necks and long legs for wading. They are shore-

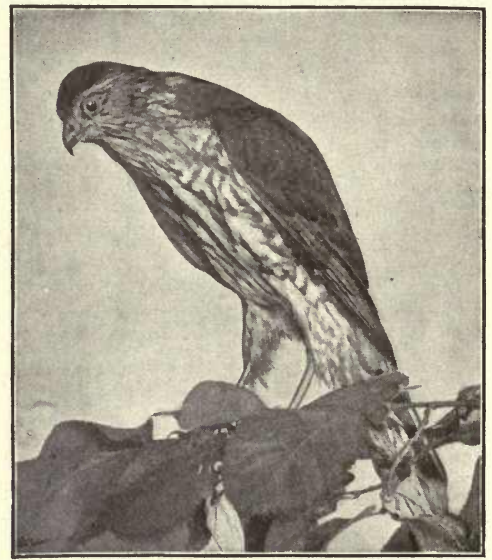

Fic. 291. - Sharp-shinned hawk one foot long. Photograph of a mount by Neal.

loving birds feeding upon frogs and fish. The great blue heron, wrongly called crane, is common in eastern North America, where it may be seen wading about in the meadows and swamps. In nesting, the herons usually form societies, so that in the space of two or three acres one may count in 
the trees more than a hundred nests. The little blue heron visits the creeks east of the Mississippi River. The snowy heron or snowy egret is the most béautiful bird in the world. Its head and back bear numerous filmy plumes which are so much sought after to adorn the head gear of women that the species once so abundant in Florida is now almost exterminated. A law has lately been passed preventing the sale of these plumes known as aigrettes. That some effective means to stop the use of song bird plumage in millinery work should be devised is evident when we consider the number of birds annually sacrificed on the altar of woman's vanity. Forest and Stream mentions a dealer who in three months supplied over eleven thou-

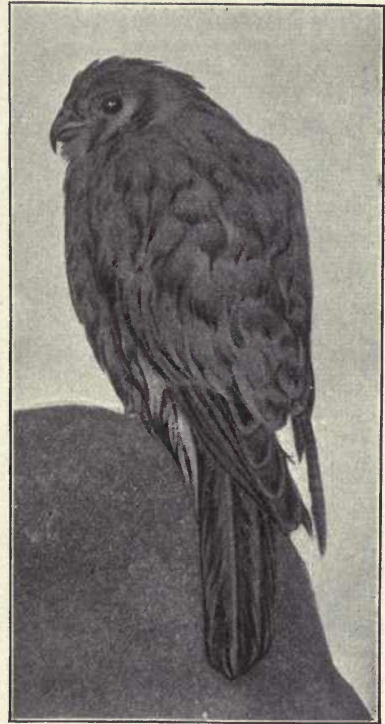

Fig. 292. - Sparrow hawk ten inches long. Photograph from life. sand skins for the milliners, and the same person is said to handle thirty thousand birdskins every year. A single foreign order given a New York milliner called for the death of over forty thousand of our beautiful birds, which were sold at ten cents each. During four months seventy thousand birdskins were sent from one Long Island vil- 


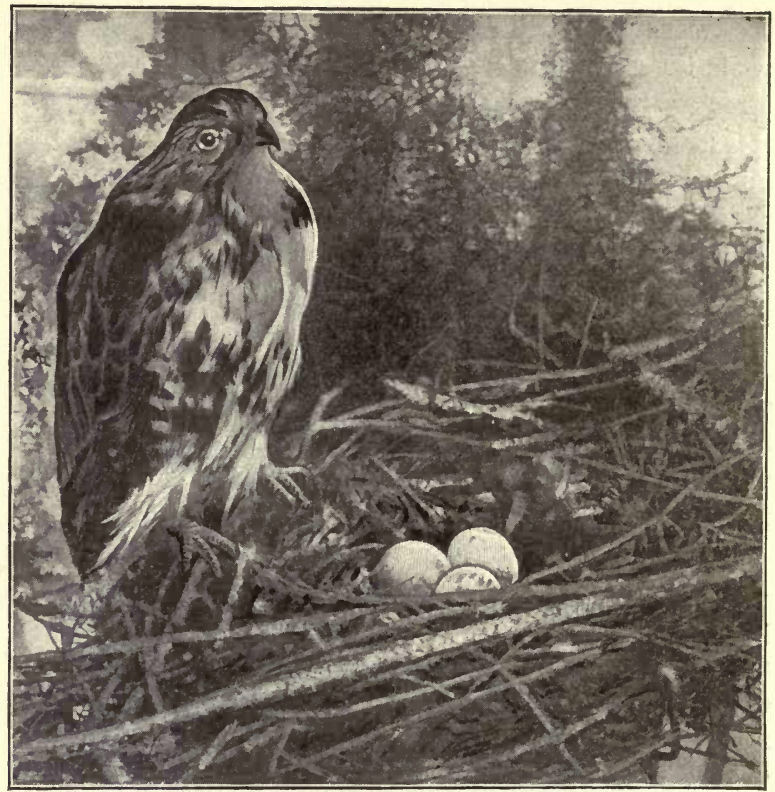

FIG. 293. - Red-shouldered hawk at her nest in the tree top. Photographed in the Academy of Natural Sciences, Philadelphia. One eighth life size.

lage to supply the peacock populace of New York. The Audubon Society has proved itself a mighty force for good not only in showing the evil wrought by collectors of birds and their eggs, but also in rendering unpopular the use of birds for millinery purposes. If every pupil will do his part in that great missionary work of protecting the birds, their nests, and young, in the coming years the dream of Shelley may be nearer realization. 
"No longer now the winged habitants That in the woods their sweet lives sing away Flee from the form of man; but gather round, And prune their sunny feathers on the hands Which little children stretch in friendly sport Toward these dreadless partners of their play. .... Happiness And science dawn, though late, upon earth."

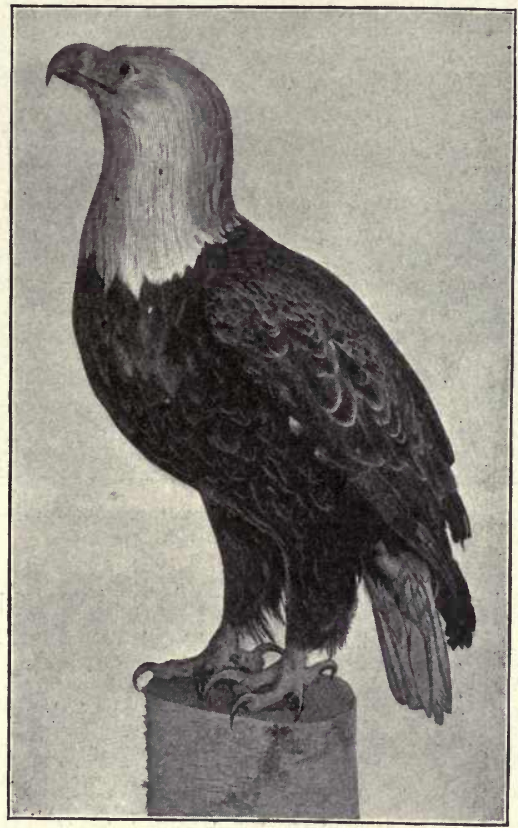

EIG. 294. - Our national bird, the bald eagle. Photograph of a mount by Neal. One sixth life size. 
That birds limit in a large degree the outbreaks of injurious animals is shown by recent reports. An apple orchard in Illinois was severely attacked by canker worms (Fig. 88) and numerous species of birds came to feed on the pests. Several individuals of each of thirty-six different species were killed and the stomach contents examined by Pro-

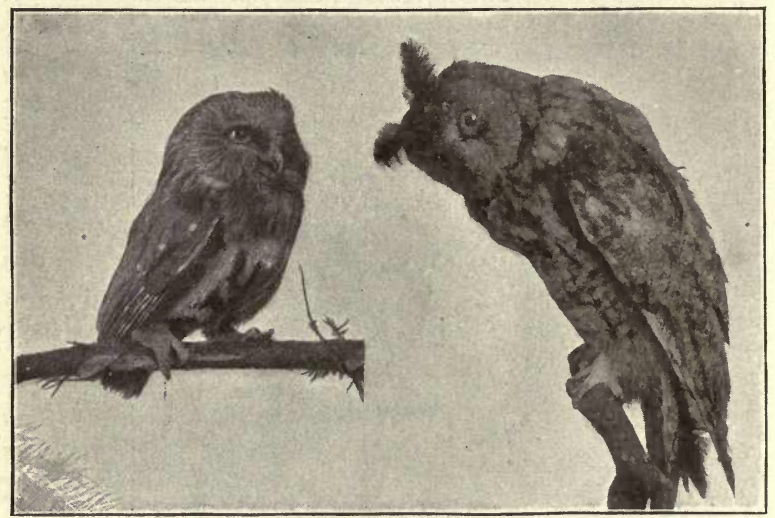

F1G. 295. - A, Sereech owl. Photograph from life. One hith uatural size. $B$, Long-eared owl.

fessor Forbes. Canker worms made up twenty per cent of the food of the robins, fifteen per cent of the food of catbirds, two thirds of the food of the warblers, forty per cent of the food of the vireos, fifty-nine per cent of the food of the indigo bunting, sixty-one per cent of the food of the chickadees, seventy-five per cent of the food of the black-billed cuckoos, and practically all of the food of the cedar birds. 
Similar striking facts are shown by Aughey's investigation during the outbreak of the Rocky Mountain locust, when in a single year, 1874, they destroyed forty-five millions of dollars' worth of crops. For one meal, six robins had eaten two hundred and sixty-five locusts; five catbirds,

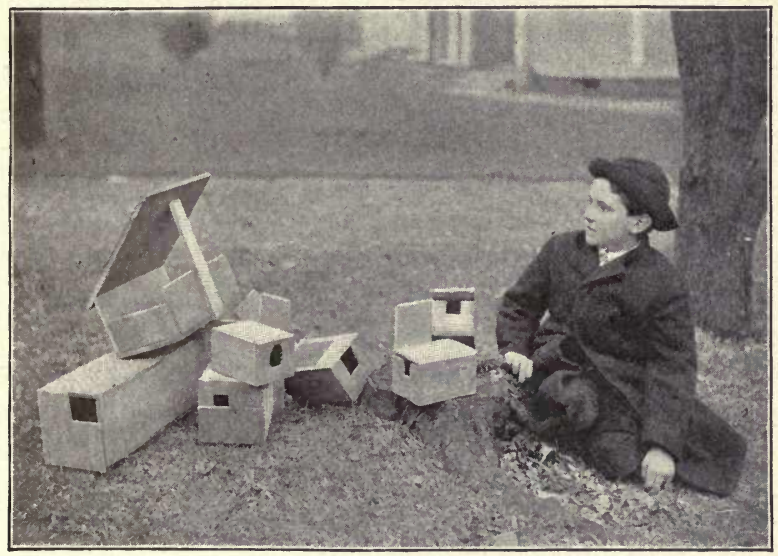

FrG. 296. - A friend of the birds.

one hundred and fifty-two; three bluebirds, sixty-seven; nine chickadees, four hundred and eighty-one; twenty swallows, five hundred and sixty-five; and eight flickers, two hundred and fifty-two. Every species, of which there were fifty present in that region, fed on the pests. Outbreaks of army worms and field mice have also been checked by the birds in a similar manner.

The pupils of every school should determine whether the number of birds is increasing or decreasing from year 
to year. An excellent method of determining this is to count the nests to be seen in the trees as soon as the leaves have fallen. Robins and some other birds use the same nest for two or even three broods in one year, but on an average it is safe to count only five birds reared from each nest. Small boys and cats are the greatest enemies of young birds near towns and cities.

The migration of birds is worthy of the attention of every one. In the latitude of New York, the chief birds remaining with us throughout the year are the owls, crows, woodpeckers, cedar birds, song sparrow, English sparrow, black-capped chickadee, and bluebird. Some of these frequently go south during severe cold weather. The other summer residents pass the winter in the South, some, like the bobolinks, going as far as Brazil.

In many cases the migration trips are made by night and often at a great height. The purple martin, the kingbird, the swallows, and the orioles depart in September, and the majority begin their southern journey in October; but the bluebird, robin, and chipping sparrow remain until November and return as early as March. The latest comers in spring are the wood thrush, vireos, orioles, bobolinks, and cuckoos, which arrive in May. The cause of bird migration is not known. Cold weather may seem to force them south, but why do they leave the warm tropical regions abounding in food in the spring and come to the bleak north?

The regions to which some of our species go for wintering are quite definitely mapped out. The robins that spend the summer in Canada have for their wirter residence portions of the United States in the latitude of 
Washington, while the robins summering in northern United States migrate to a winter home along the Gulf of Mexico. The nighthawks, living in Alaska from May to September, fly over five thousand miles to their congenial winter home in Patagonia. Over fifty species of New England birds winter in South America. Twenty-five species from northern United States pass the winter in Porto Rico, an equal number go to Cuba, and at least twenty species remain during our cold season, in Jamaica. Others, such as the red-eyed vireo, migrate to Central America.

Every school should keep a record of the time of the appearance of each species in the spring and its departure in the autumn. The pupils should be encouraged to report how many birds they have coaxed to dwell in the yard and garden by putting out meat bones and bread crumbs in winter, and erecting nesting boxes for summer.

\section{I9. MAMMALIA}

The mammals are distinguished from all other vertebrates by their habit of providing the young with milk and by the possession usually of a hairy covering. Like the birds they are distributed throughout both the warm and cold regions of both hemispheres. Since the habits as well as the structure of the different groups vary widely it will be necessary to consider the characteristics of each of the eleven orders.

Egg layers (Monotremata). - The ducls mole of Australia is one of the three species of mammals which lay eggs. It deposits in its burrow on the bank of a stream 


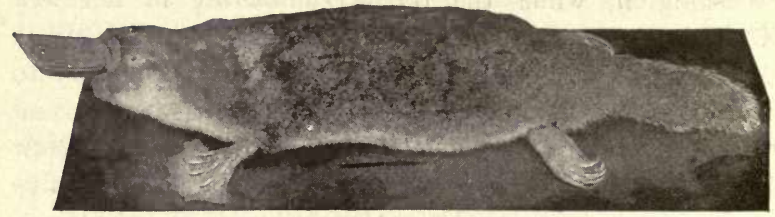

FIG. 297. - The duck mole or duck bill. Photograph one fourth natural size.

two eggs about as large as those of a robin. The Echidnas, of which there are two species, inhabit Australia and New Guinea. The single egg deposited is placed in the abdomi-

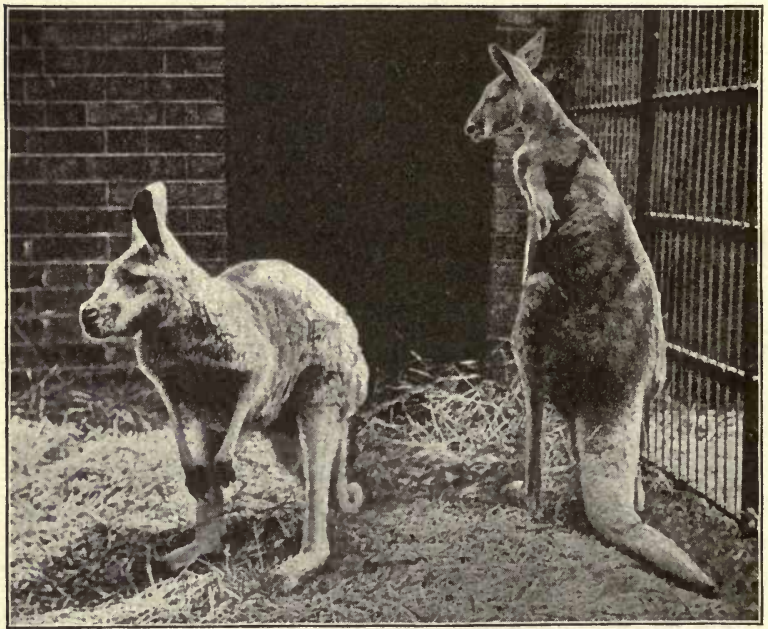

FIG. 298. - Kangaroos. The one at the left shows the opening to the pouch. 
nal pouch where the young one, soon hatching, is carried for some weeks.

Pouched Mammals (Marsupialia or Didelphia). - The marsupials, though not oviparous, approach that condition inasmuch as the young are born in a very immature condition and in most cases are carried in the pouch by the female several weeks. The largest species of the

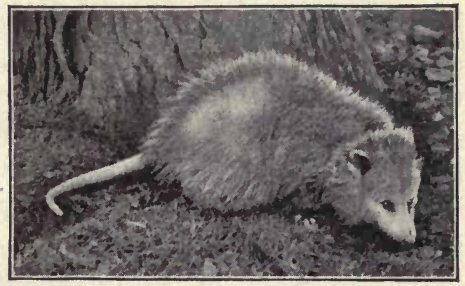

FrG. 299.-Virginia opossum. Photograph by N. F. Davis. One eighth life size. kangaroos dwelling in Australia is the boomer, standing four feet high and capable of clearing twenty feet at a single bound. The opossums are the only marsupials living in North America. The one representative in the United

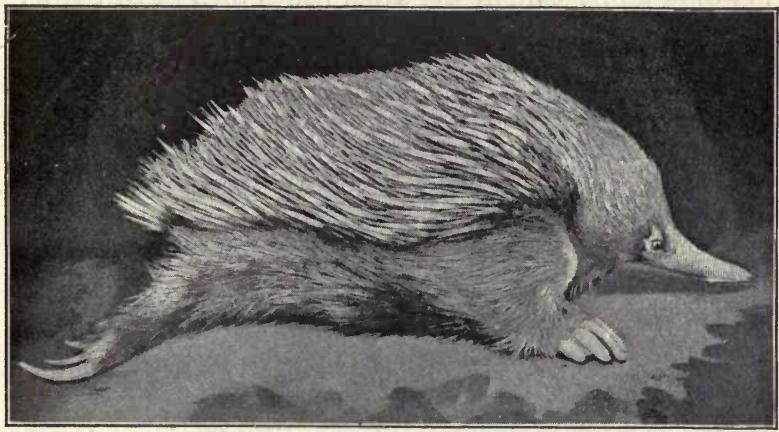

Frg. 300. - The spiny ant-eater (Echidna). Photograph one fourth life size. 
States is the Virginia opossum found in nearly every state. The young varying in number from six to twelve are naked, blind, and about half an inch long at birth, when the mother by means of her fore paws places them in her pouch. Here they remain several weeks constantly attached to the teats through which the mother pumps the milk into their mouths.

Ant-eaters (Edentata). - This order is so named because some of the species have no teeth. The armadillos, remarkable for their covering of bony plates, inhabit South America and southern North America, while the ant-eaters dwell in South America, Asia, and Africa. The Sloths live in South America only.

Sea cows (Sirenia). - The members of this order are characterized by the absence of hind limbs and the presence of paddle-like fore limbs adapted for an aquatic life. The manatee is the only representative in our country. It swims in the rivers of Florida. The fact that the flipperlike fore limbs contain the same bones present in the terrestrial mammals, indicates that the ancestors of the Sirenia were land mammals.

Whales, Dolphins, and Porpoises (Cetacea). - These, like the Sirenia, are entirely aquatic, and with few exceptions live in salt water only. They are characterized by the absence of hair and hind limbs, though in some species rudiments of the latter are found beneath the skin, indicating that the whales have descended from land animals with two pairs of limbs. The toothless, or baleen whales, are valuable both for oil and whalebone. The largest species, the sulphur-bottom whale of the Pacific, attains a length of ninety-five feet, One individual will yield three 
hundred barrels of oil and two tons of whalebone. The toothed or sperm whales inhabit both the great oceans. The dolphins occur in schools and dart out and in the water at frequent intervals. The common Atlantic porpoise is the puffer seen rolling in the breakers near the shore.

\section{Hoofed Mammals (Ungulata). -} The members of this order are notable for the variation in the number of digits (toes or fingers) from one to five. The horses are one-toed; the cattle and deer, two-toed; the pigs, four-toed; and the elephant, five-toed. This condition is explained by the theory of evolution, declaring that all ungulates originally had five digits to each limb, but in some cases one or more has been lost because they were not of. advantage to the species. The ancestors of the horse known by fossil remains exhibit four complete toes, and the most ancient mammals, living several millions of years ago, all had five toes on each limb. Rudiments of these lost digits are present

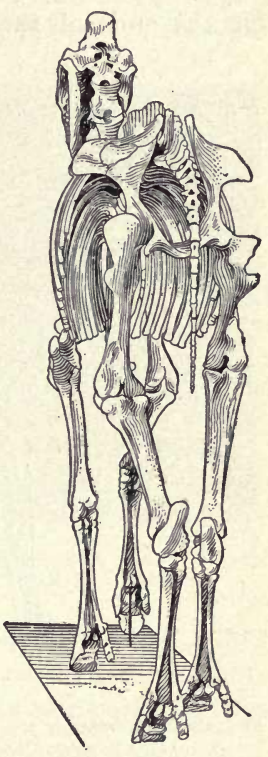

Fra. 301. - Skeleton of a horse that lived in Colorado more than a million of years ago. From Guide Leaflet of the American Museum by Matthews. in the horse, deer, and cow. The digits are numbered from the inside outward, i.e., from the thumb toward the little finger. The horse walks on the end of the third 
digit, so that the wrist and ankle, often wrongly called the knee, are more than a foot above the ground, while the real knee is close up to the body. Animals walking on the ends of their toes are said to be digitigrade, in

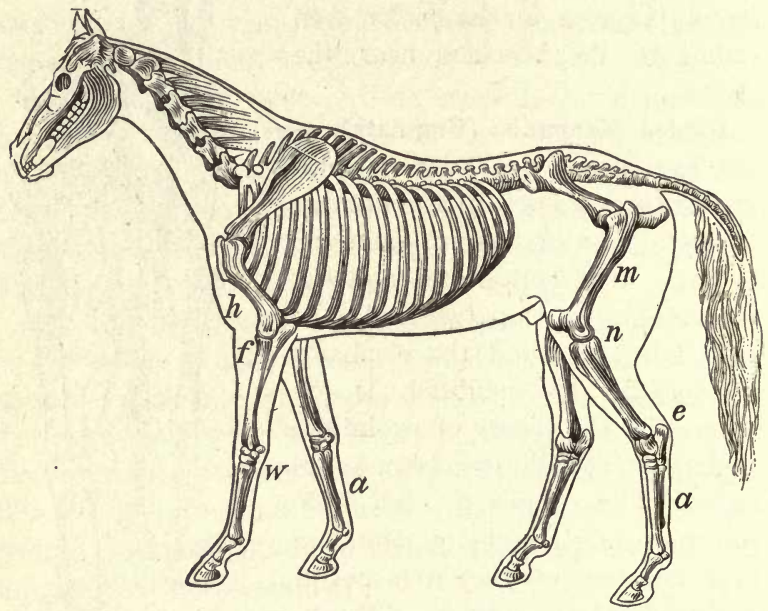

ETG. 302. - Skeleton of the horse. $\alpha$, rudiment of the fourth digit (splint bone) about half as long as the third; $d$, second digit; $e$, ankle; $w$, wrist; $n$, knee; $m$, femur ; $f$, forearm with large radius and rudimentary ulna; $h$, humerus.

distinction to those walking on the flat of the foot, called plantigrade.

The cattle family (Bovida) includes the goats, sheep, and cows, among the most celebrated of which are the American bison (buffalo) now nearly extinct, and the Rocky Mountain goat able to walk on almost perpendicular cliffs. 
The deer family (Cervidox) is well represented on all the continents except Africa. With the exception of the caribou only the males of the deer possess antlers, and they are always shed annually, and usually in February or March. A new growth begins at once and continues so rapidly that antlers like those of the elk measuring four feet are renewed in less than four months. The elk, the largest species of the roundhorned deer, abounds in the vicinity of the Yellowstone Park.

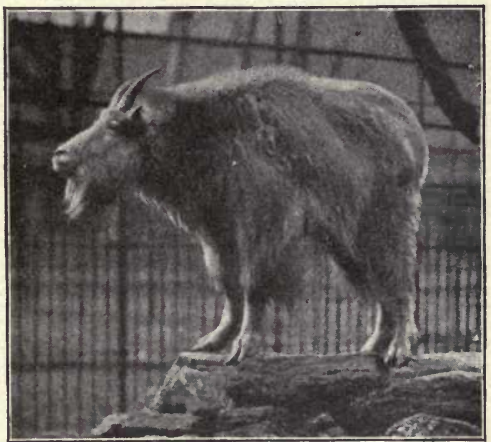

FiG. 303.- Rocky Mountain goat. Photographed in the Philadelphia Zoölogical Gardens.

The Virginia deer, also called white-tailed deer, inhabits every state in the Union except Delaware, Oregon, Nevada, California, and Arizona, but is most abundant in the Adirondacks, Maine, Vermont, and Michigan.

The moose, the largest species of the deer family, reaches a height of nine feet. The overhanging nose, high-humped shoulders, and huge flat antlers of the male distinguish it from the other deer. It is found in northern United States, Canada, and Alaska. The caribou or reindeer, both sexes of which bear slightly flattened antlers, occupy the upper half of the continents of North America and Eurasia, where they feed upon moss and lichens. The domestic 
reindeer (Rangifer tarandus) is a native of Siberia whence over fifteen hundred animals have been imported into Alaska since 1892, and they have multiplied to the number of several thousand. During the last few years the United States Government has granted annually twenty-five

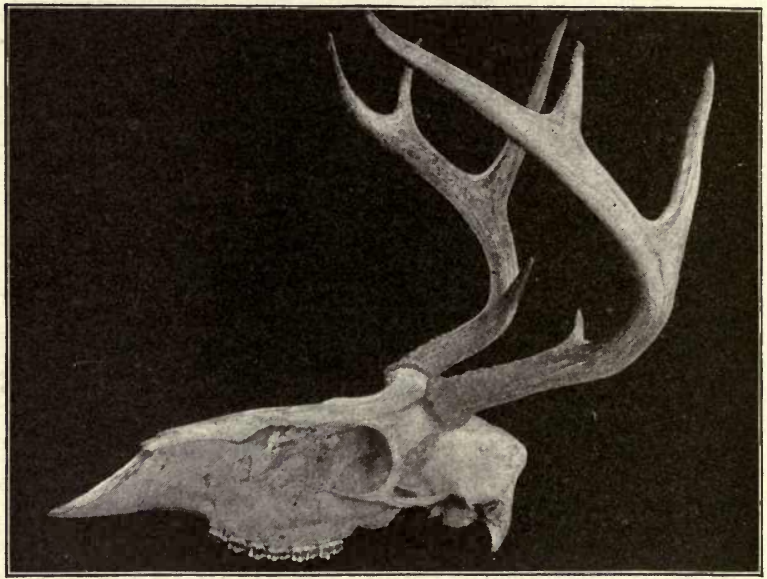

Frg. 304. - Skull of a deer with the lower jaw removed. The burr at the base of the antler shows where it separates. The absence of upper incisors and canine teeth is characteristic of ruminants (cud chewers).

thousand dollars for the purpose of making the reindeer a permanent resource for food and domestic service among the Eskimos.

The camel of Africa, the "llama of South America, and the elephant of Africa and Asia have been trained to render valuable service to man. The water sacs, which are numer- 
ous pouches on the wall of the stomach, enable the camel to go many hours without water in the sandy Sahara. The tusks of the elephant are the two upper overgrown incisor

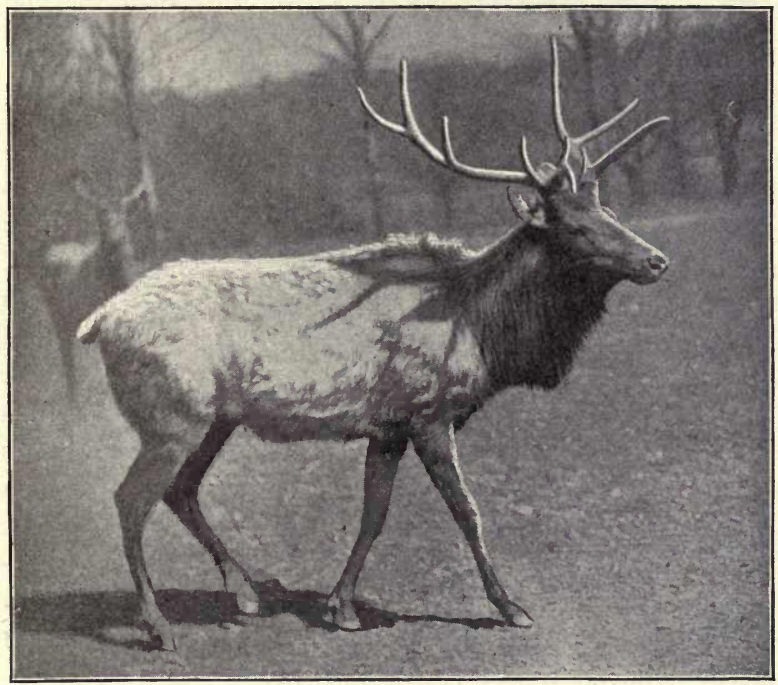

FIG. 305. - Wapiti or American elk. Photographed in the Philadelphia Zoölogical Gardens.

teeth composed almost entirely of dentine, which furnishes the ivory of commerce.

Gnawers (Rodentia). - Any one of the four hundred species of rodents living in America may be recognized by the large chisel-shaped incisor teeth, of which there are two in the lower jaw and either two or four in the upper one, while the canine teeth are wanting (Fig. 309). 
The squirrels (Sciuride) are represented by the chipmunks or ground-squirrels, usually striped, the red squirrel living in northeastern United States, and the gray squirrel

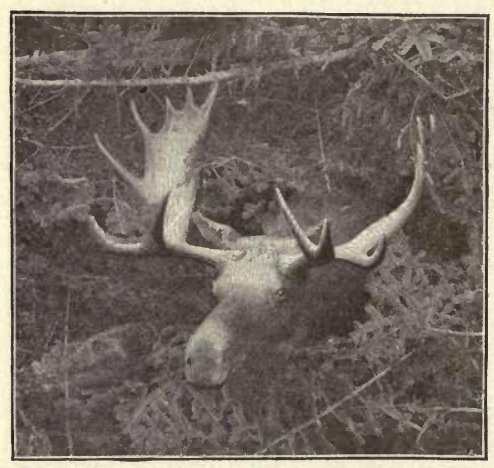

FIG. 306. - A moose pushing its way through the underbrush. inhabiting the forests east of the Rocky Mountains. The red squirrel deserves to be exterminated, as it drives away the gray squirrel and destroys the eggs and young of the song birds. The marmots are burrowing rodents much larger than the true squirrels.

The woodchuck (Marmota monax) abounds nearly everywhere east of the Rockies. Instead of storing up food like the squirrels it hibernates during the cold season, and when removed from its burrow in winter appears to be in an unconscious condition. The heart beats but a few times per minute and respiration is very slow, so that the food stored up largely in the form of fat in its own body enables it to pass the cold season without eating. The prairie dog, ranging from Texas to Canada, is a social animal dwelling in large colonies sometimes more than fifty miles in length.

The rats and mice (Murida) number about one hundred and seventy-five species in North America. The muskrat 
is aquatic in habit, dwelling in holes along the banks of streams. The brown rat (Mus decumanus) has spread from its original home in western China throughout the whole civilized world. About 1730 it migrated into Russia, appeared in Paris in 1750, was introduced into

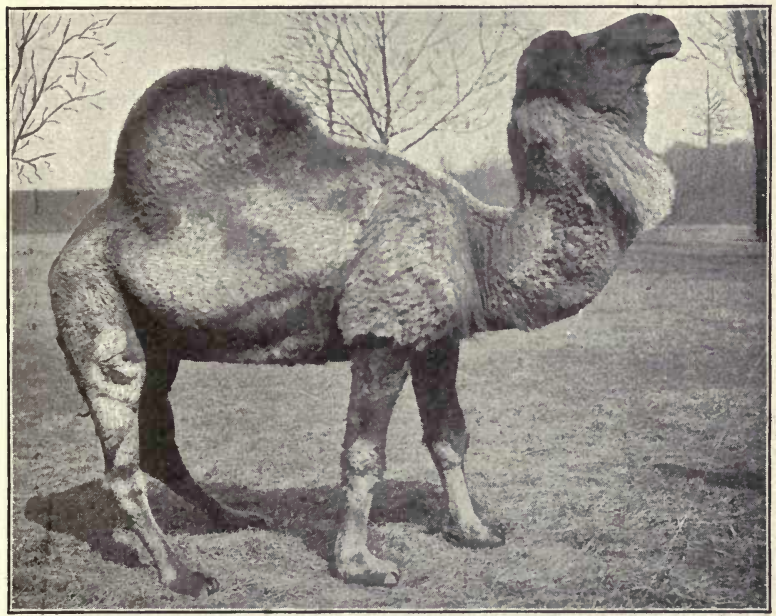

FIG. 307. - Camel. Photographed in the Philadelphia Zoölogical Gardens.

America along the Atlantic coast in 1775, and by 1850 had spread to the Pacific coast. It destroys young poultry, eggs, and grain. Like the house mouse, it multiplies rapidly, producing three or four litters annually of from five to ten each.

The hares and rabbits (Leporida) are widely distributed. The former have long ears and long legs, while in the latter 
these organs are comparatively short. Rabbits introduced into countries where their natural enemies, hawks, owls, eagles, and carnivorous mammals are not sufficiently abundant to keep them in check, have become great pests. In Australia they devoured the grass to such an extent

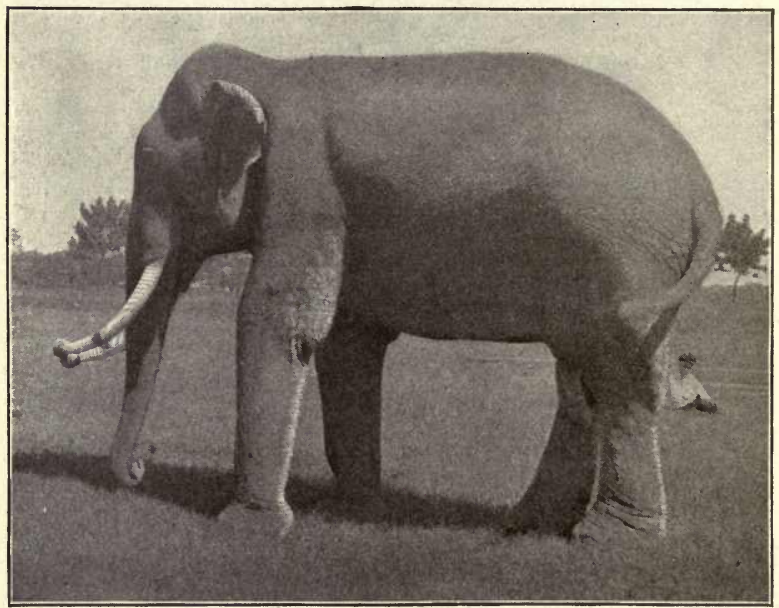

FIG. 308. - Photograph of the elephant showing the external nares at the end of the trunk.

that thousands of sheep starved to death. Fifteen million skins were exported from New South Wales in one year. In some places the government has erected fences of wire netting to keep the pests from destroying the crops. Since the killing off of the coyotes and wolves in western United States, the jack rabbits have increased enormously, so 
that at intervals "drives" are held. On these occasions as many as twenty thousand animals are slain in one day.

Bats and FlyingFoxes (Chiroptera). - Unlike most of the rodents, the greater number of the chiroptera are beneficial on account of the harmful insects they

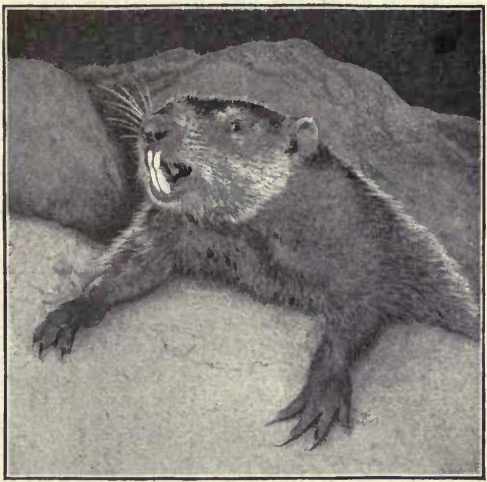

FIG. 309. - Woodehuck or ground hog. Photograph one fourth life size. destroy. They are nocturnal and spend the day in caves and forests. The bones of the fingers are much extended

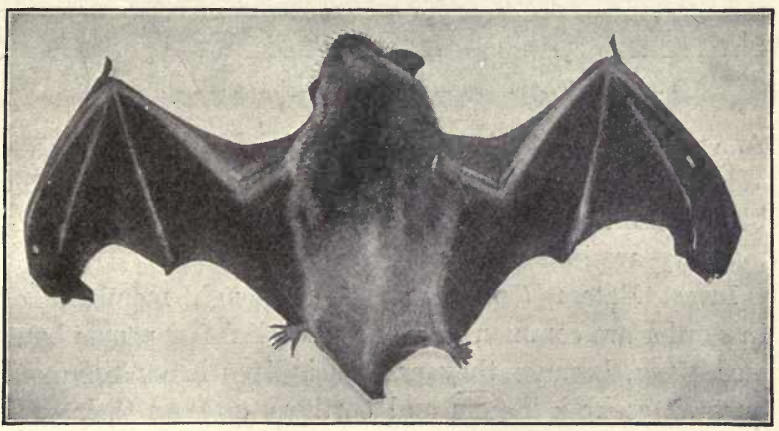

FIG. 310. - The red bat photographed from beneath. Half life size. 
so as to subtend the large membrane stretching from the hind limb, thus affording the means of flight. Among the insect eaters occurring in our land are the red bat and brown bat flitting through the air at twilight. The fruit eaters or flying foxes, including some species with a wingspread of three feet, inhabit southeastern Asia and adjacent islands. The vampire bats are confined to Central

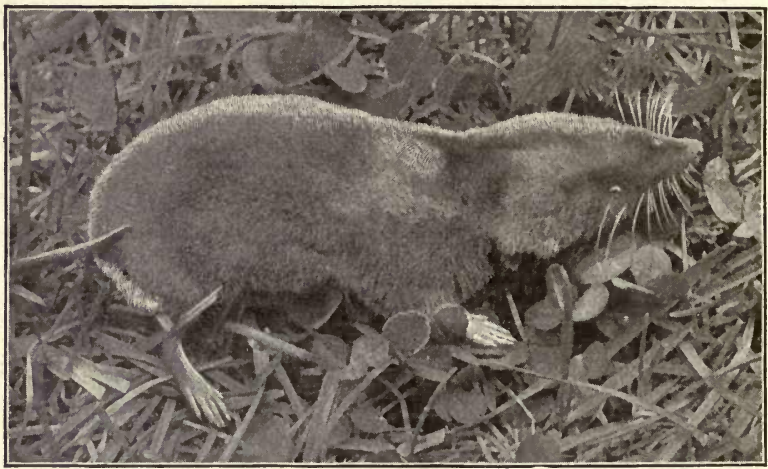

FIG. 311. - Short-tailed shrew. Photograph two thirds life size.

America and South America and the West India Islands. While a few of them, such as the Javelin bat, suck the blood from horses and cattle and even attack man, the majority are insect or fruit eaters.

Insect Eaters (Insectivora). - Although members of this order are common in every state, but few people have seen them, because they pass their lives in underground burrows seeking insects and earthworms. As their eyes are of no use in the dark, they have become rudimentary 
in many species and appear as mere dark spots. The shrews, numbering thirty-five species, are characterized by a pointed nose and small feet, while the moles have extremely large fore feet enabling them to excavate rapidly the tunnels whose elevated roofs form serpentine figures over the lawns. The hedgehogs, distributed throughout

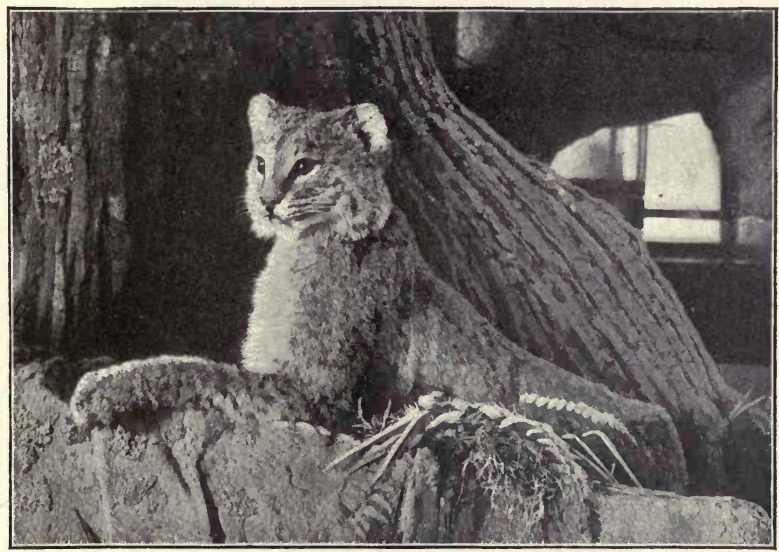

FIG. 312.- Wild cat (Lynx rufus). Photographed in the American Museum of Natural History.

Europe, Africa, Asia, and some of the adjacent islands, are covered on the upper surface with an armature of spines, and possess the power of rolling themselves up into the form of a ball.

Flesh Eaters (Carnivora). - Nearly a hundred species belonging to this order dwell in North America. Their distinguishing features are large canine teeth, flesh-cutting 
molars, and clawed toes. The cats (Felida) are represented in this country by the jaguar of Texas, the puma or mountain lion of the western states, Adirondacks, and Florida, and the bay lynx, called wildcat or catamount,

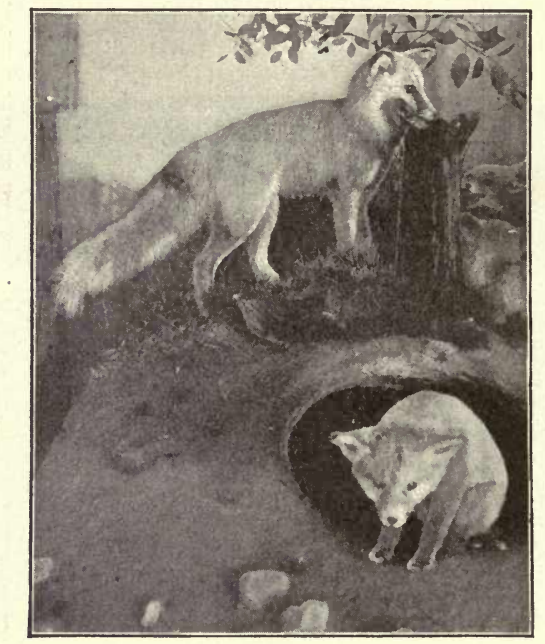

Fig. 313. - Red foxes at the entrance to their underground home. Photographed in the American Museum of Natural History.

inhabiting the thickets of nearly all the states east of the Mississippi.

The domestic cat is thought to be a descendant of the Egyptian cat (Felis caffra) widely distributed in Africa. The lion and tiger, dwelling in the Old World, are the most formidable of the tribe. In India the tiger is said to destroy twenty thousand cattle annually. Certain indi- 
viduals acquiring a love for human flesh are known as maneaters. To these, several hundred of the natives of India fall victims every year.

The dogs (Canidoe) include the wolves and foxes. The coyote and prairie wolf breed in the rocky caverns and washouts of the Rocky Mountain region and the great

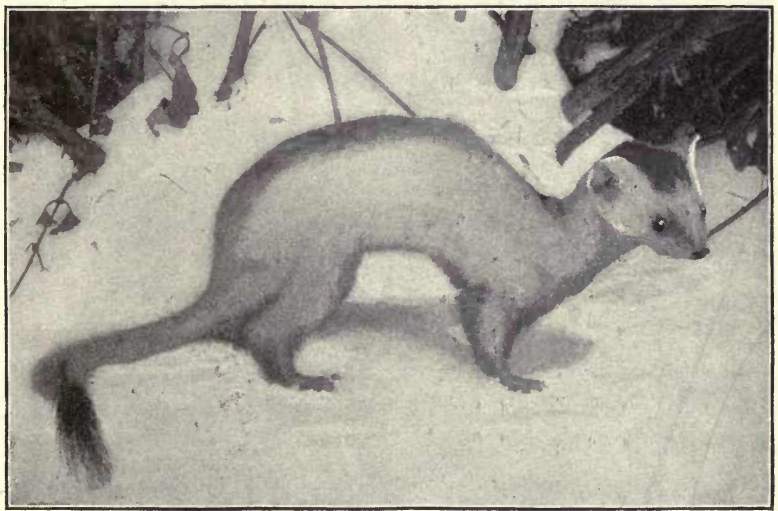

F1G. 314. - The Weasel (Putorius erminea) in winter. One fourth natural size.

plains, and make life uncertain for the cattle, sheep, and poultry. A study of structure and habits makes it evident that many of the one hundred and fifty varieties of our domestic dog (Canis familiaris) originated from wolves, while it is probable that others are descendants of jackals. The foxes, of which there are four species in our country, are inuch valued for their fur. The red fox (Vulpes fulvous), widely distributed east of the Mississippi, exhibits 
a remarkable variation in the color of its fur. While ordinarily of a reddish hue it occasionally varies to a jet black. The red skin is valued at only one or two dollars, but a black one sometimes sells for as much as two thousand

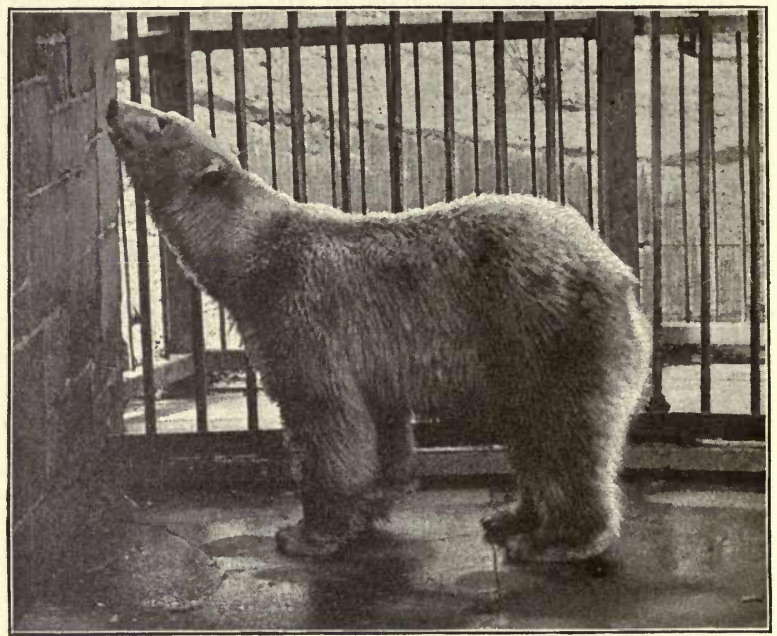

FIG. 315. - Polar bear (Thalarctos maritimus). Photographed in the Philadelphia Zoölogical Gardens.

dollars. The gray fox is confined to the more southern portions of the United States.

The marten family (Mustelide) includes the fish-loving otter, slender-bodied mink and weasel, the marten, skunk, and badger, all of which are valuable fur-bearing animals. The weasel and mink are destructive to poultry, but the weasel atones for his evil by terrorizing the rats and mice. 
Like many other creatures in the north the weasel changes from brown to white in winter. The source of the white ermine is the stoat or ermine occupying the northern part of both hemispheres.

The hears (Ursida) are represented in our country by four species, of which the black bear (Ursus americanus) has the widest range. It is found in many of the forests

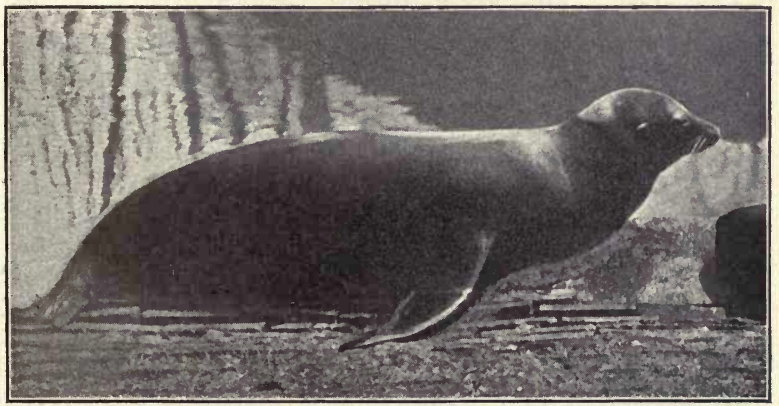

FIG. 316. - The California sea lion (Zalophus californianus). Photographed in the Philadelphia Zoölogical Gardens.

from Florida to Alaska. The color varies frequently to a brown in the western states, where it is called the cinnamon bear. The large grizzly bear of the Rockies is said to have killed and maimed more hunters than all the other bears of the world combined. The polar bear inhabits the coast of the Arctic Ocean, where it feeds upon fish and seals.

The Pinnipedia include those carnivora whose limbs are adapted for swimming. They are the sea lions, seals, and walruses. The large canines forming the long ivory tusks in the upper jaw distinguish the walrus from the other two 
groups. The sea lions resemble the seals, but have no external ears and no hair or claws on the front flippers. The neck of the sea lion is much longer than that of the seal. Sealskin fur is not derived from a seal, but from the sea lion (Callotaria ursina), breeding only in the region of the Behring Sea, although making circuits in winter as far south as San Francisco.

Primates. - This order includes the lemurs, monkeys,

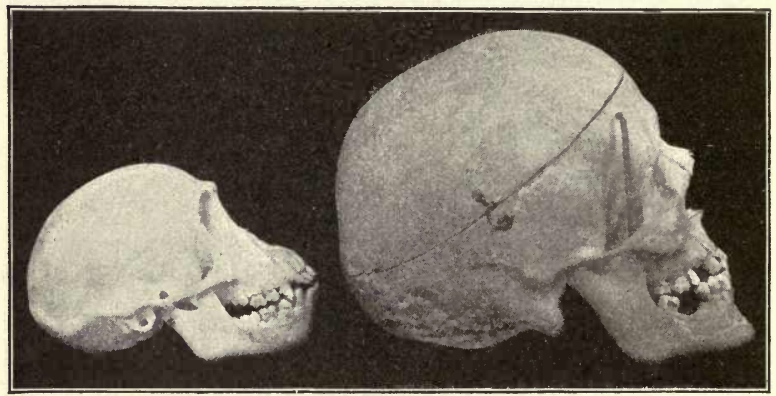

Fig. 317. - Skull of man on the right and young chimpanzee on the left. Photograph.

and man, all of which have hands and handlike feet, and in most cases the thumb is opposable to the fingers, so as to grasp a limb. The lemurs of Madagascar are the lowest Primates, and with the exception of their grasping hands and feet resemble externally some of the Carnivora. The common black and white lemur is about as large as a cat. About twenty species of monkeys of a low order extending from Mexico to Brazil are included in one family, the marmosets. They are all small, but few being larger than squirrels, and are characterized by toes with pointed claws, 
a nonopposable thumb, and the absence of wisdom teeth. The New World monkeys are marked by a flattened nose with the nostrils separated by a broad septum. They range from Mexico to Brazil. Many of them have prehensile tails with which they are able to support themselves from the limbs of trees.

The best known groups of the Old World monkeys are the baboons, apes, and gibbons. The baboons have long, doglike noses and live only in Africa. They travel in troops of a dozen or more, robbing grain fields and fighting fiercely when attacked.

The anthropoid apes (Simiidde), of which there are about ten species, include those monkeys having no tails and for the most part bearing a striking resemblance in structure to man. The gibbons are of small size, slender pro-

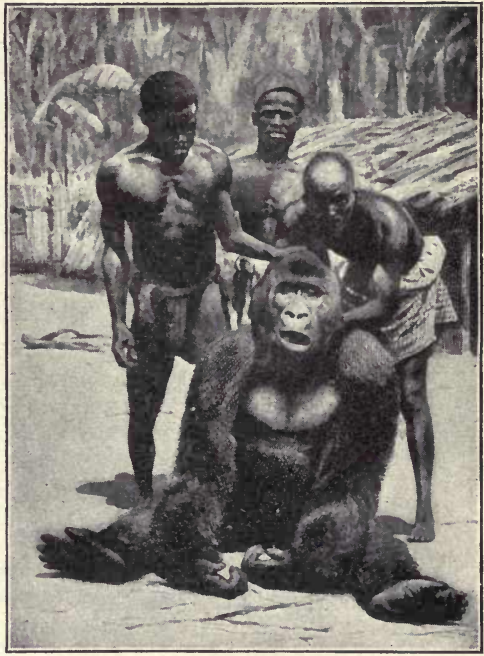

FiG. 318. - Gorilla shot and photographed in West Africa. By permission of the Academy of Natural Sciences. portions, and of low intellect. They inhabit Borneo, Sumatra, the Malay Pcninsula, and Siam. The gorilla 'Gor- 
illa gorilla) is the largest, fiercest, and most manlike of the apes. It is the only one which walks erect without being taught, and in its home land along the equator of Africa it is said to spend much time on the ground. It does not thrive in captivity. Only one live specimen has ever arrived in the United States.

The chimpanzee, half as large as the gorilla, has brain, face, ears, and hands more manlike than those of any other ape, and is the most intelligent of the group. Sally of the

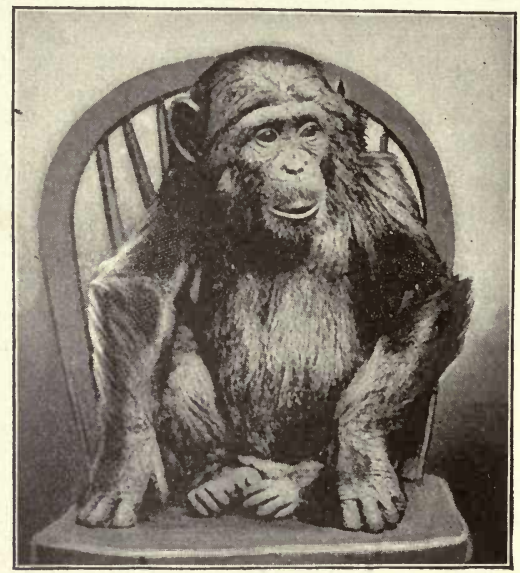

FIG. 319.- Photograph of a chimpanzee.

London ' Zoo could count up to five. Its home is in the dense forests of equatorial Africa. The orang-outang, about two thirds as large as the gorilla, may be distinguished from the black-haired chimpanzee by its reddish hair, 
brown skin, and small ears. It manifests an intelligence almost equal to the chimpanzee. The young are readily trained to sit at a table, eat with a spoon, drink from a cup, and give other performances. It lives in Borneo and Sumatra.

Structure of a Mammal. - The structure of a mammal may be understood by dissecting any one of the smaller forms, such as the rat, guinea pig, rabbit, or cat. Although

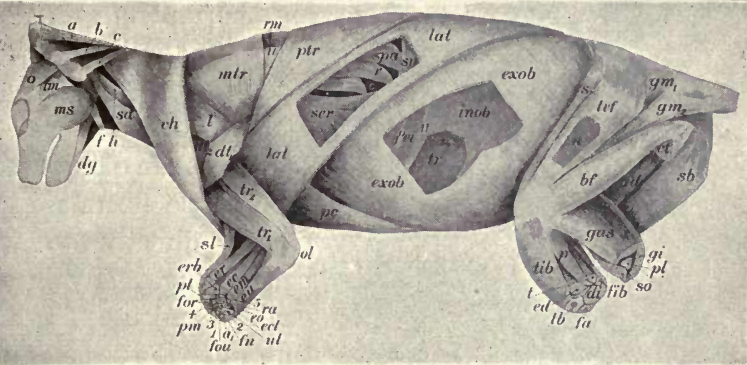

Fra. 320. - Side view of the muscles of the eat's body. An irregular rectangular piece has been cut from each of the two large side muscles and the two limbs have been cut off near'the middle showing the bones white. From Davison's "Mammalian Anatomy."

the description here given applies specially to the cat, yet any of the other species named may be used, as the structure of all is practically the same. The animal can be painlessly killed in twenty minutes by placing it in a small, tight box or tin can containing a cloth or piece of cotton wet with an ounce of chloroform or ether.

The skin should be removed by making a șlit in it along the median ventral line and by pulling the cut edge outward 


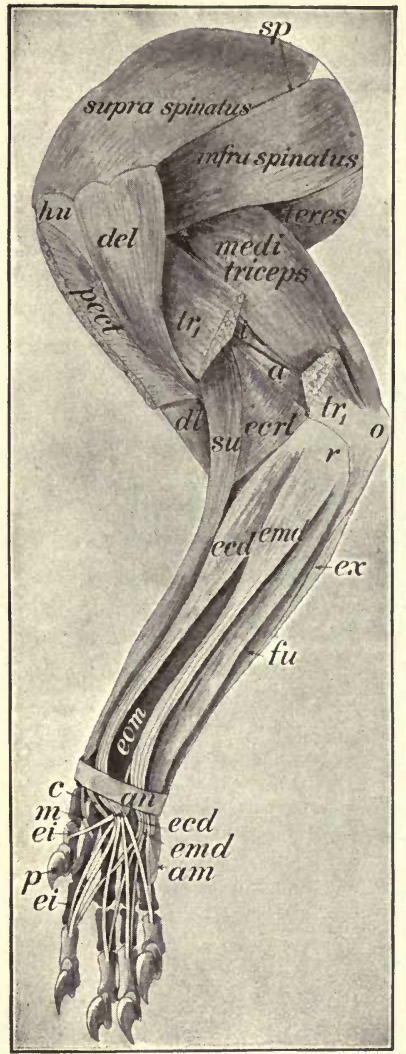

FIG. 321.-Muscles on the outer side of the eat's fore limb. A piece has been cut from the triceps. The white cords in the region of the foot are tendons; an, a ligamentous band. From Davison's "Mammalian Anatomy." and severing the white fibrous connective tissue uniting the skin to the muscles. Many of the five hundred muscles forming the flesh are seen to be composed of three parts. The white glistening part usually connecting the muscle at either end with the bone is the tendon, and the larger middle portion is called the belly. In many cases the muscle fibers are attached directly to the bone without any intervening tendon. The nature of the thousands of striated muscle fibers forming the muscle is easily demonstrated by tearing into minute shreds with two sharp needles a bit of muscle placed in a little water or alcohol on a glass slide, and then examining it under the high power of the microscope. A cover glass should be placed on the 
specimen and care taken that there is sufficient liquid to fill the space between the slide and cover glass. By pulling on the muscles in the lower part of the limbs it may be seen that those on the back side bend the digits and are therefore called flexors, while those on the front side straighten the digits and are accordingly named $e x-$ tensors. Those muscles attached to the upper limb regions pulling them outward are the abductors, while those drawing them inward like the great breast muscle are adductors.

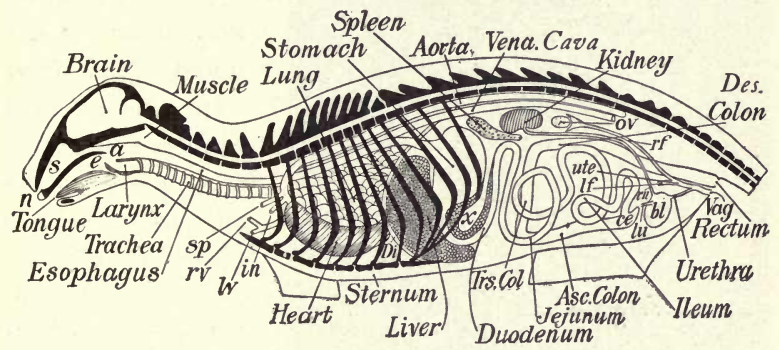

F1G. 322. - Diagram of the chief organs of a mammal. The bones are black. $a$, opening from the nasal cavity $s$ to pharynx; $b l$, bladder; $c e$, cæcum; $d i$, diaphragm; $e$, epiglottis; $n$, nostril or anterior nares; ov, ovary; $r f$ and ute, uterus ; $r u$ and $l u$, ureters ; $x$, pancreas; vag, vagina. From Davison's " Mammalian Anatomy."

By cutting away the thin layer of muscle forming the ventral wall of the body cavity the internal organs may be examined. The diaphragm, a thin plate of muscle, divides the thoracic cavity containing the heart, trachea, lungs, and esophagus from the abdominal cavity containing the stomach, intestines, the large dark red liver composed of several lobes adjacent to the diaphragm, the pinkish-white pancreas lying along the bend of the intes- 
tine near the stomach, the dark-red tongue-shaped spleen, a kidney on either side of the backbone, and a pear-shaped urinary bladder into which two ureters lead from the

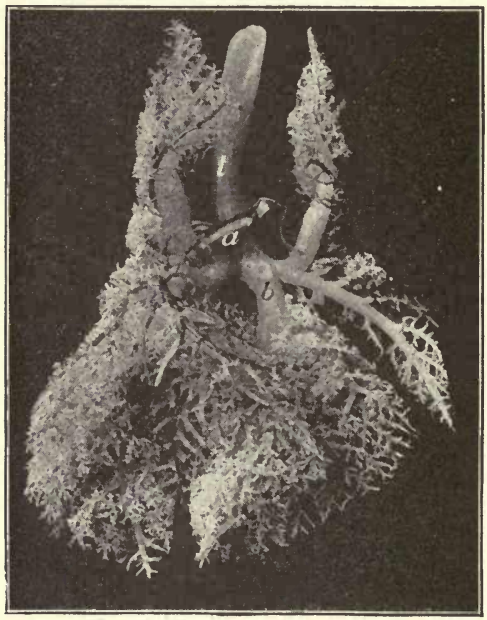

Fig. 323. - Photograph of a lung corrosion prepared by Mr. Sylvester. The trachea with all of its branches was filled with melted white wax and the pulmonary artery was filled with red wax, and the specimen then placed in a jar of acid to eat away the lung tissue. $t$, trachea ; $a$, artery to right lung; $b$, left bronchus giving off air tubes to the left lung. The expanded air sacs at the ends of the minute branchlets are broken off. From Davison's "Mammalian Anatomy."

kidneys. The thin transparent membrane lining the abdominal cavity and investing the organs therein is the peritoneum. The similar membrane in the thorax is the pleura. These membranes secrete a colorless serum and are therefore called serous membranes, to distinguish them from the mucous membranes lining the alimentary canal and all other cavities to which the air has access.

By cutting a small slit in the windpipe distinguished by its numerous incomplete cartilaginous rings, and inserting and tying fast therein the end of a small glass or thin tube through which to blow, the lungs may be inflated as in inspiration performed by 
the living animal. The two vocal cords may be seen by cutting the larynx lengthwise. They are flat ligamentous folds on either side of the larynx.

The vessels remaining full of blood are the veins. The arteries are of a lighter color, and contain little or no blood. The main vein of the trunk is the vena cava, which opens into the upper right cavity of the heart, called the right auricle. From here the blood passes to the right lower cavity, termed the right ventricle, which by the contraction of its strong muscular walls forees the blood through the pulmonary artery

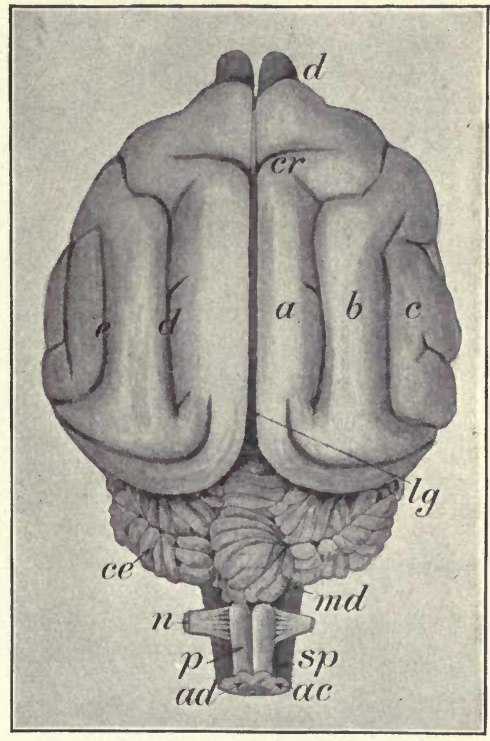

FxG. 324. - Cat's brain viewed from above. $a, b, c$, convolutions of the cerebrum ; $c e$, and $v$, cerebellum; $m d$, medulla oblongata; $n$, stump of the nerve supplying the shoulder region; $s p$, spinal cord; $a d$, body of nerve cells forming the gray matter ; $a c$, processes of nerve cells forming white matter. Three fourths natural size. From Davison's " Mammalian Anatomy."

to the lungs, to exchange the carbon dioxide, a waste substance collected from all parts of the body, for oxygen. The blood is returned from the lungs by sev- 


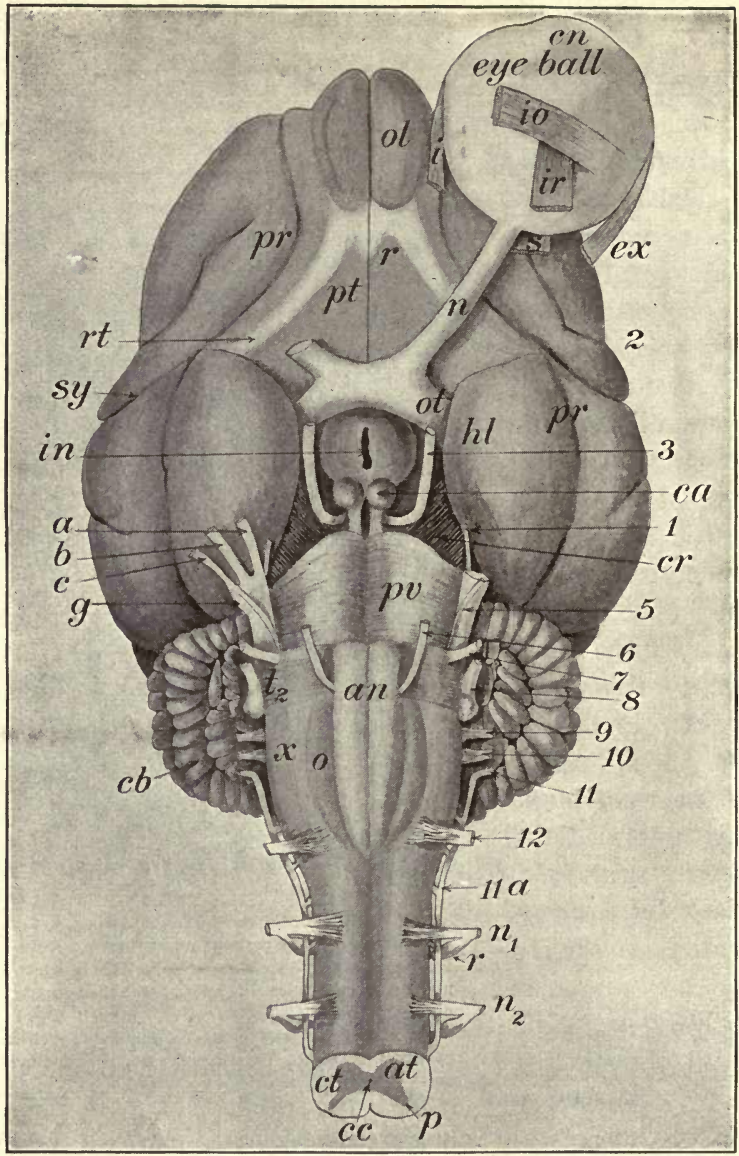

FIG. 325.-Cat's brain vlewed from beneath. The numbers refer to the nerves supplying the head and neck; $i, i o, i r, e x$, and $x$, muscles for moving the eyeball; $n$, optic nerve ; op, optic chiasm; ol, olfactory lobe ; $s y$, cerebrum ; $c b$, cerebellum ; an, medulla oblongata ; $p v$, pons Varolii ; $c c$, spinal cord. Slightly enlarged. From Davison's "Mammalian Anatomy."

(288) 
eral veins emptying into the left upper cavity known as the left auricle and then goes to the left ventricle, which by contraction of its walls propels the blood through the aorta and its hranches to all parts of the body. The membranous valves, held by white glistening cords, between the auricles and ventricles prevent the backward flow of the blood.

The nerves are the white glistening cords extending along with the blood vessels and giving off numerous branches to the muscles and other structures. They are connected either with the spinal cord or the brain. Those

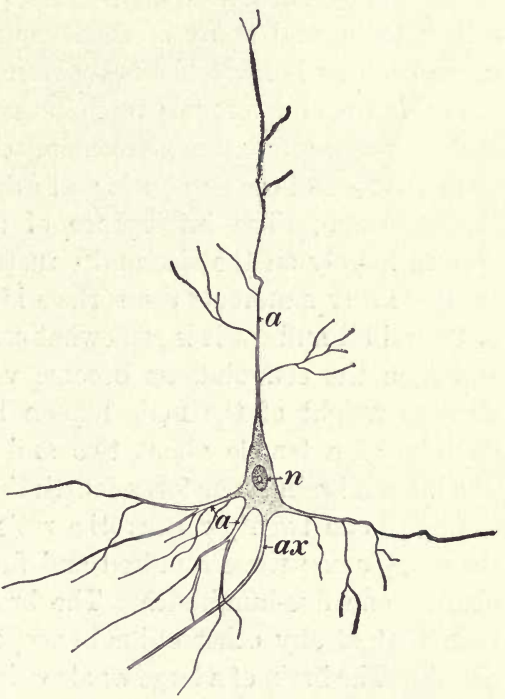

EIG. 326. - Nerve cell from the brain; $a$, processes by which it communicates with other cells near by ; $a x$, long process or axis cylinder terminating in the tail end of the spinal cord; $n$, nucleus. Enlarged two handred diameters. From Davison's "Mammalian Anatomy."

nerves which carry sense stimuli, such as sound or a pin prick to the brain or spinal cord, are called sensory nerves, while the others bearing impressions from the brain or spinal cord to the muscles are termed motor nerves. The 
spinal cord and brain form the central nervous system which the microscope shows to be composed of millions of cells with processes varying in length from a hundredth of an inch to nearly a foot. The longer processes are called fibers, and many of them bound together form a nerve such as is most distinctly seen in the limbs.

The brain of mammals is composed of five parts: the medulla oblongata, the cerebellum, the cerebrum visible from above, and the mid brain and interbrain lying beneath the cerebrum. The intelligence of an animal seems to depend largely on the size and structure of the cerebrum. In the lower mammals the surface is quite smooth, while in the rabbit and cat it is somewhat convoluted, and in ape and man the convolutions become very numerous. The average weight of the male human brain is about three pounds; of a female about two and two thirds pounds. The human brain is one forty-fourth the weight of the body; the ape's one twenty-ninth; the rat's one eighty-second; the sheep's one three hundred and fifty-first, and the elephant's one five-hundredth. The brain of man is larger than that of any other animal except the whale and elephant. The brain of a large whale weighs over four pounds, while that of a large elephant will weigh about ten pounds.

The skeleton of the cat consists of more than two hundred bones united to each other by tough bands of tissue called ligaments. The three parts of the skeleton are the head, trunk, and extremities. Except the lower jaw, the bones of the head are immovably united to each other. The bones of the trunk are capable of only limited motion, but free movement occurs between several of the limb bones. A typical mammalian fore limb consists of a shoulder blade 


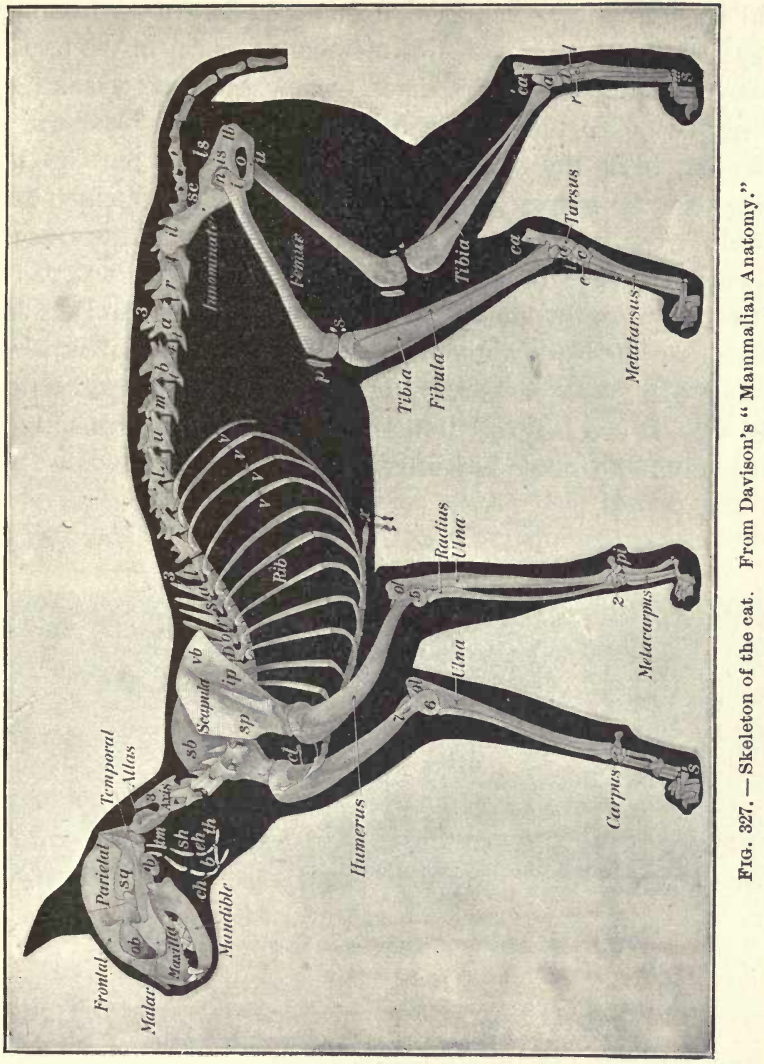


or scapula, the arm bone or humerus, the ulna and radius in the forearm, several small bones in two rows forming the carpus or wrist, and five metacarpal bones in the hand, each bearing three phalanges, except the first, which has only two. In the hind limb the femur occupies the thigh region, while the tibia and fibula in the lower part of the leg join the several small bones of the ankle to which are united the five bones of the foot, called metatarsals, each bearing three phalanges, except the first, which has only two. In many forms some of the digits are wanting and others are inore or less rudimentary, as in the cattle, horses, and pigs. In some cases the ulna and radius are grown together, as are also the tibia and fibula, and in these species the ulna and fibula are usually rudimentary. 


\section{PART IV \\ ANIMAL LIFE}

\section{FROM EGG TO ADULT}

Eggs of Animals. - With the exception of the Protozoa, all species produce specialized cells capable under certain conditions of developing into new animals similar to the parents. Such cells are known as ova or eggs. These are so small in some of the invertebrates as to be invisible to the naked eye, while in some of the fish they are as large as a pinhead, and in reptiles and birds many times larger. The egg of the alligator is more than two inches in diameter,

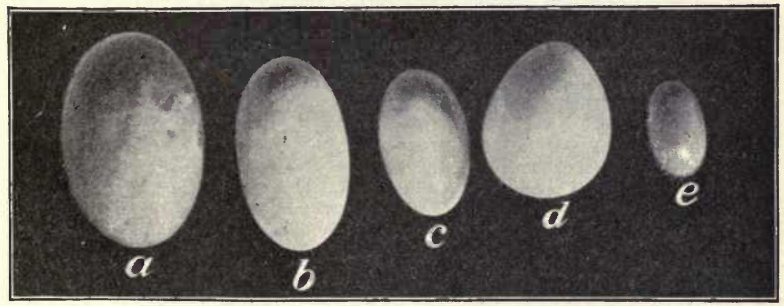

FiG. 328. - Eggs of vertebrates. $a$, pond turtle; $b$, black snake; $c$, garter snake; $d$, woodpecker; $e$, lizard. Photograph two thirds natural size.

and that of the ostrich is more than six inches. The real difference between the small egg of the fish and the large egg of the bird is in the amount of the yolk and albumen 
stored up as food for the young. Within the shell of a hen's egg is sufficient food to nourish the growing chick, called the embryo, until it is able to run about. If a fresh egg be placed in water and a circular piece of shell removed with the scissors, a white spot a quarter of an inch in diameter lying on the yolk is seen. This is a young chick composed

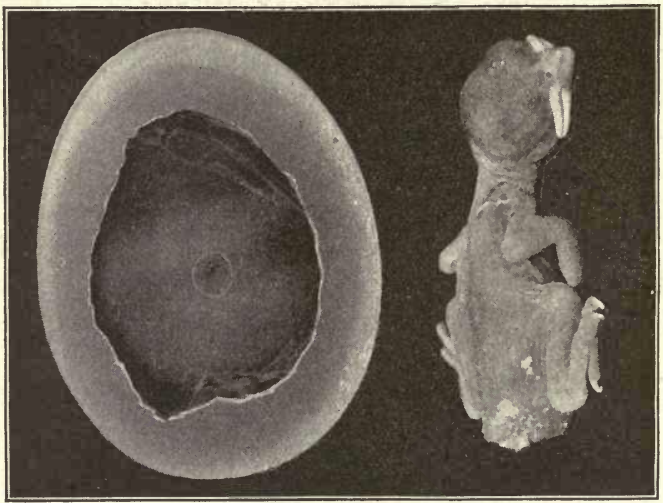

FIG. 329. - At the left a fresh hen's egg showing the young chick at the center. At the right an English sparrow one day old. Photograph.

of several hundred cells which have developed during twenty-four hours from the one cell formerly occupying this place. Some birds are in a helpless condition when hatched, and must be fed by the parents several days before they can fly or walk. The eggs of frogs and toads containing but little food material for the young are small, and in growing the whole egg may be seen with the naked eye to divide into two cells within two or three hours after 


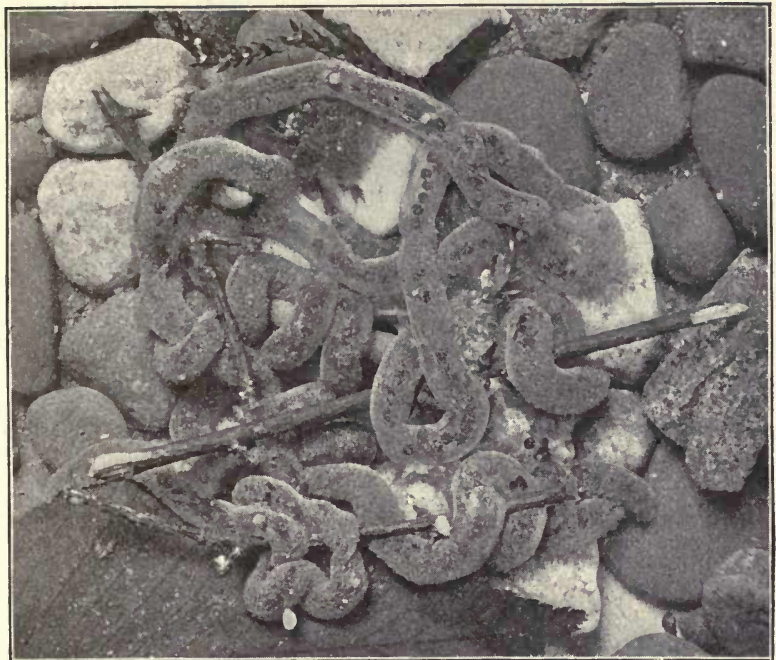

FIG. 330. - Strings of toads' eggs each of which is a single cell. Photograph natural size.

being deposited in the water. An hour later four cells are visible, then eight cells, after which division occurs more rapidly (Fig. 332).

Many animals retain their eggs in the body during development. Such are certain flesh flies, plant lice, some of the sharks, the copperhead, rattlesnake, and most mạmmals.

Development of Young. - In numerous species, the young does not continue its development uninterruptedly but at certain periods rests and undergoes remarkable 


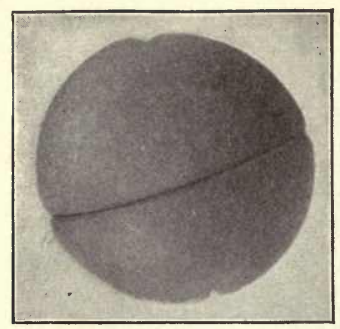

FIG. 331.-Amphibian egg of two cells with the furrow forming to divide it into four cells. Photograph through the microscope enlarging twenty diameters. changes in form and structure. The egg of the jellyfish does not produce directly the freeswimming parent form, but develops into what is known as the hydra tube (Fig. 203), which after a time by transverse division gives rise to several jellyfish. The egg of a tapeworm eaten by an animal becomes in a favorable host a somewhat globular body known as the cysticercus or larva. In this condition it may live for months or possibly years until the flesh containing it is eaten by the proper host for the development into the complete tape form. The larva of the cat's tapeworm lives in the mouse, and the tapeworm of the dog is a cysticercus in the rabbit (Figs. 184, 185).

Among the insects very marked differences in form occur during the life of the young. In some orders, such as the

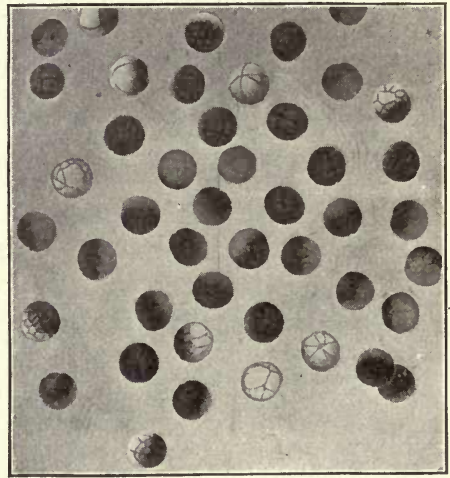

Fig. 332. - Frog's eggs from three to ten hours old. All stages from four cells to thirty-two cells may be noted. Photograph enlarged four times. 
Neuroptera, Coleoptera, Diptera, Lepidoptera, and Hymenoptera, as many as four stages are distinguished in the life

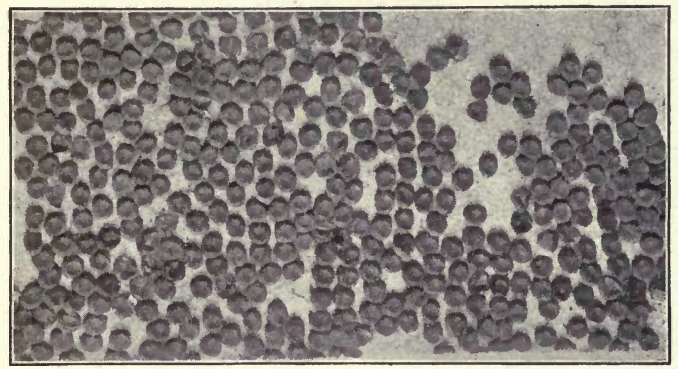

FIG. 333. - One fourth of the eggs laid by a silk-worm moth. Twice natural size.

cycle. The transformation from one stage to the next is called metamorphosis.

The egg hatches into the larva, which is a wingless and often wormlike form having but little resemblance to the

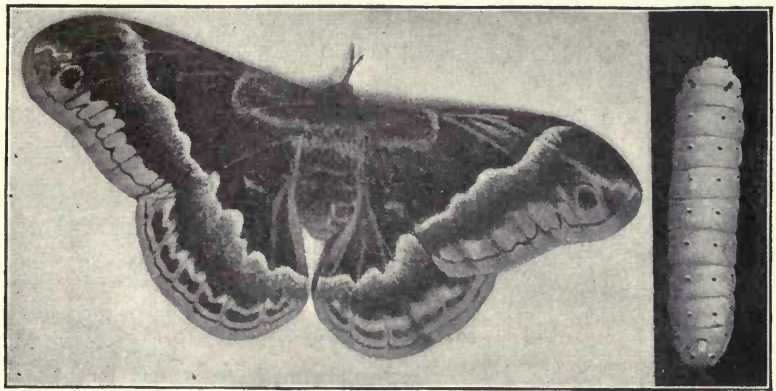

FrG. 334. - Promethea moth, larva and adult. Photograph nearly natural size. 


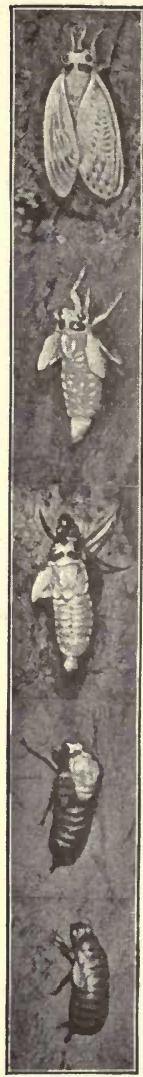

FIG. 335. - Metamorphosis of the cicada as it occurred between 8 P.M. and midnight. Flashlight photograph two thirds natural size. honey bee. parent. The larval stage may continue from three days to three years, depending largely on the species but somewhat upon the food and temperature. It is longest in the Coleoptera and Neuroptera. Before entering the third stage, that of pupa, the larva sometimes forms a case of particles of earth, or weaves a cocoon from its silk glands or from hairs of its body (Fig. 75). The deathlike sleep of the pupa continues from a week to a year, depending upon the species. No food is taken and any temperature from twenty degrees below zero to one hundred degrees above does not seem to harm the insect, but the wonderful reorganization of structure necessary to assume the form of the parent does not take place except during mild weather. The adult stage is usually a winged form, which may not live more than a week, as in the case of many moths, or may exist five or six years, as in the case of the queen

Some insects, such as the locusts, grasshoppers, cicadas, dragon flies, and May flies, do not exhibit any marked difference in form between the larval and pupal states, and are therefore spoken of as having an incomplete metamorphosis (Figs. 7, 140). The young is then usually called the $n y m p h$ and continues active at all times. Often the life of the 
adult insect is passed in a realm quite different from that of the larva. The mature dragon flies, May flies, and hellgramite are inhabitants of the air, while the larval young dwell in the water. The adult cicadas love the pure air and sunshine, but their larvæ are subterranear wanderers.

Many of the crustaceans exhibit a complete metamorphosis, and in numerous species three or four stages are discernible. In the case of the small crustaceans (Entomostraca), including the barnacles and shrimps, the larval form hatching from the egg is known as the nauplius. It differs from the adult in having usually but one eye and three pairs of leglike appendages which later become transformed into the antennules, antennæ, and mandibles. The body is not segmented. In the barnacles a second larval stage occurs, called the cypris, characterized by a two-valved shell, six pairs of swimming feet, and paired compound eyes. Certain of the larger crustaceans (Malacostraca) exhibit two stages in development known as zoë $a$ and mysis. The larval stages last but a few days, and in any species are passed through in the egg.

Some of the mollusks, especially the bivalves, pass through a larval state known as the veliger. It is a minute, free-swimming form. In the case of the fresh-water mussel a second larval stage occurs, while as a parasite it is attached to a fish. The eggs of the sea-urchin and starfish do not hatch directly into forms resembling the parents, but give rise to young differing as widely from the adult as the caterpillar differs from the butterfly.

Even among vertebrates, as in the case of some fish and all amphibians, the development from egg to adult is 
indirect. The larva of the lamprey eel presents features of such contrast to its parent that for many years it was

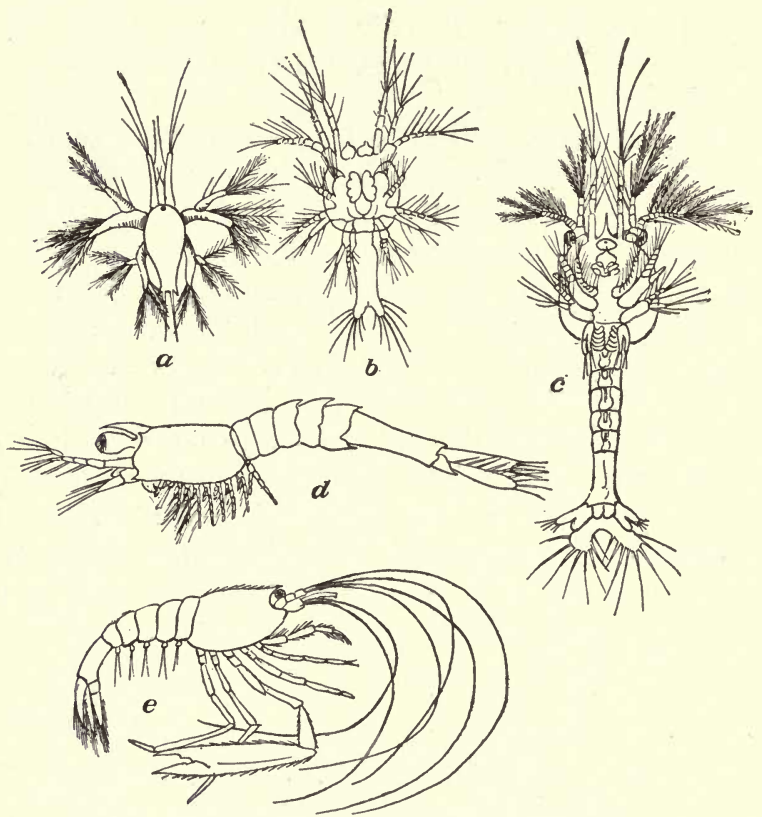

FrG. 336. - Metamorphosis of a shrimp. $\quad a$, nauplius; $b$, first zoæa stage ; $c$, second zoæa stage; $d$, mysis stage; $e$, adult. From Weismann after Müller.

considered an animal of different species and named Ammocœtes. It has an over-arching upper lip instead of a round sucking mouth, rudimentary eyes, and gill pouches opening into the pharynx instead of into a respiratory 
tube. It spends four or five years in the mud along the banks of the stream, while the adult is a free swimmer

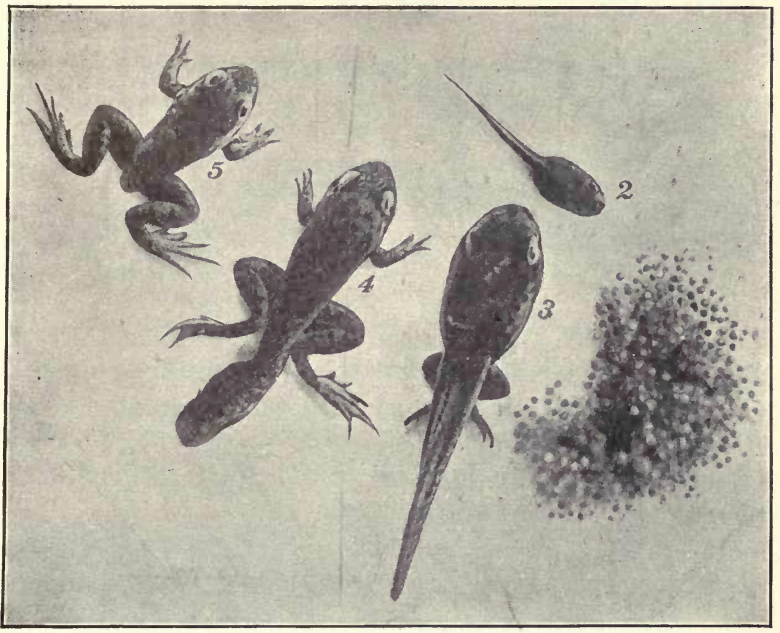

FIG. 337. - Life cycle of the frog passed through in four months. 1, mass of eggs; 2, month-old legless tadpole. Photograph one half life size.

(Fig. 215) in the ocean. The young of the bony eel is likewise very different in form from its parent.

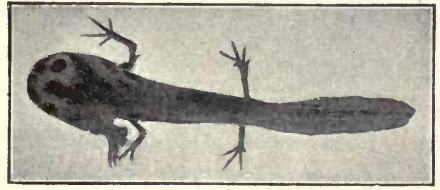

Fus 338. - Axolotl or larval form of an amblytoma. Photograph from life.

Very remarkable transformations occur among the amphibians. Most of them in the adult state are air breathers, but with few exceptions the larvæ 
are aquatic. The common toad, though a lover of the dryest soil, habitually repairs to the quiet pool in late spring to deposit its five thousand eggs in a gelatinous

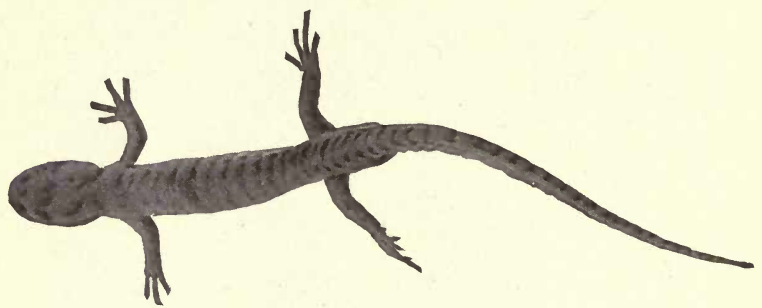

FIG. 339. - Mature A mblystoma one half natural size.

string, from whence issue in a week the well-known black tadpoles, legless and lungless, and in fact with no semblance to their warty mother. They breathe by means of gills, to which there is a small opening on the left-hand side of the neck. In a month or two hind legs appear and the front ones break through the skin as the tail begins to be absorbed. Meanwhile, lungs have developed within and the young, an inch or less in length, are ready for life on land. Frogs frequently continue

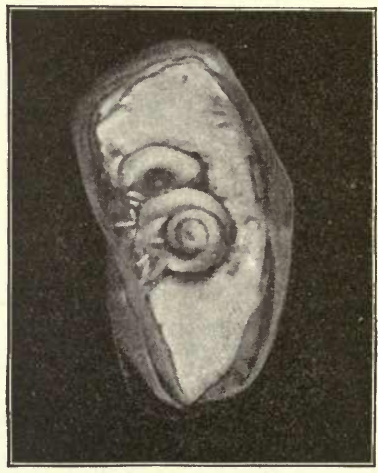

FiG. 340. - Embryo snake within the egg from which the top of the shell has been cut away. 
in the larval stage over winter, hiding in the mud at the bottom of the ponds. One of the urodeles, the axolotl, usually continues in its larval condition throughout life. The drying up of the water causes it to assume the adult form when it is known as an amblystoma. Cold and lack of food may prolong the larval life of some species several months.

Among the higher vertebrates the developing young, up to the time when it assumes the characteristic form of the parent, is called the embryo.

\section{SENSES OF ANIMALS.}

Sense of Feeling. - There are probably no animals, however simple in structure, which do not respond to certain kinds of stimuli. While it is true that none of the protozoa or sponges and but few of the worms and mollusks can see or hear, yet the sense of feeling seems to be present in all animal life. The amœba can distinguish between a particle of sand and a bit of flesh. The Paramœcium brought from darkness in to bright light responds by vigorous movements, owing doubtless to the fact that the protoplasm of all parts of the body is sensitive to the light rays, but the animal can not be said to see. The more complex the nervous system the more acute is the sense of feeling, which is the only sense with organs widely distributed over the body. The most sensitive parts in the Hydra and sea anemone (Fig. 342) are the tentacles. The loss of a leg or wing or even of a portion of the body of an insect seems to cause the creature little or no pain. With a pair of sharp scissors one may cut a third of the abdomen off the mosquito while it is 
sucking blood, and the parasite will in some cases continue feeding.

Among the higher vertebrates some areas of the skin are more sensitive than others. If the points of two pins be pressed to the skin at a distance of less than two inches

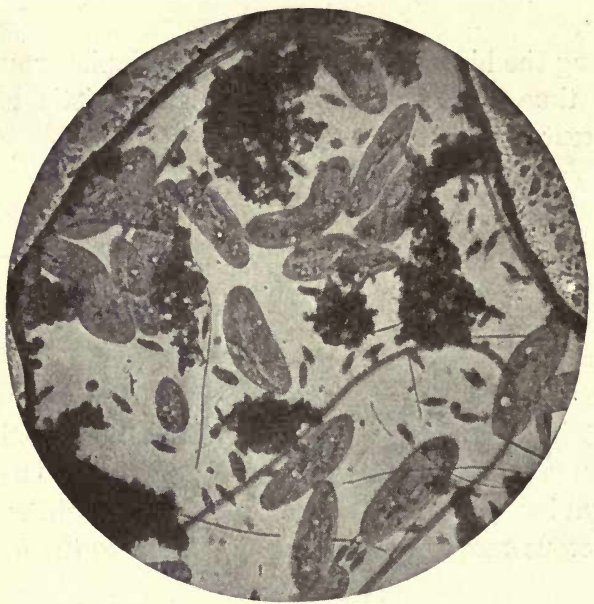

FIG. 341. - The slipper animaleules (Paramoeium). Photograph from life through the microscope.

apart on the middle of the human back, only one point will be felt, but on the tip of the tongue two separate points may be distinguished when only one twenty-fifth of an inch apart. In the higher animals the sense of feeling depends upon the presence of special nerve terminations from which lead nerve fibers to the spinal cord or 
brain. In the mesentery of the cat the oval nerve terminations are just large enough to be clearly visible to the naked eye (Fig. 343).

The sense of taste is located in the mouth or near the entrance to it. Among mammals it depends upon certain

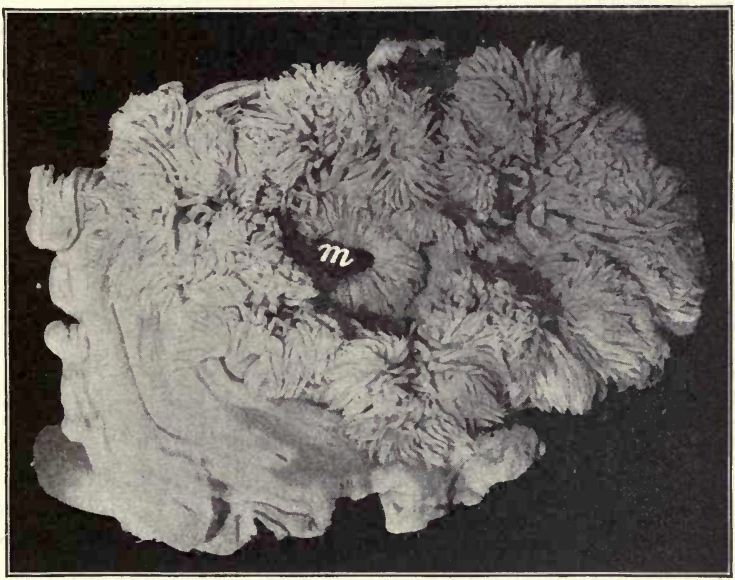

FIG. 342.- Sea anemone. $m$, mouth; the projecting mass at the right is a bud which will soon form a new animal. Photograph two thirds natural size.

nerve terminations in the mucous membrane of the tongue, palate, and neighboring regions. Special flask-shaped endings are numerous in the several large papillæ arranged in a $\mathrm{V}$-shape at the back of the tongue. So acute is the sense of taste in the human that a woman is said to have detected one part of quinine in five million parts of water.

Little is known concerning the sense of taste in the 


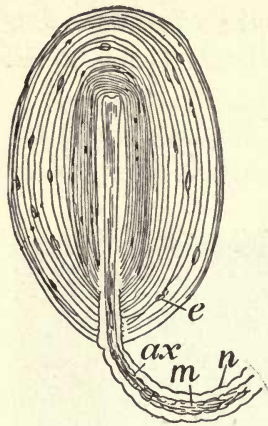

Fra. 343.- Sensory nerve termination in the mesentery of the cat. From Davison's "Mammalian Anatomy."

lower vertebrates, but numerous experiments have been made with insects. Most caterpillars will refuse all but one or two kinds of leaves, and many bugs will die of starvation rather than suck the juice of plants to which they are not accustomed. When the sugar upon which bees are feeding is exchanged for pulverized alum, the insects splutter and spit in a way that indicates a well-developed sense of taste. Ants love sugar, but if strychnine is mixed with it they reject the food at once. The organs of taste in insects are minute pits containing fine taste hairs. They are present in the maxillæ and tongue of ants, bees, and wasps, and on the proboscis of the flies.

The sense of smell varies widely in efficiency among the different animals. It is well developed in most terrestrial mammals, but more or less rudimentary in the other classes of vertebrates. A dog familiar with the smell of his master can track him through a crowded street with the same ease that we can follow a man by sight. A deer will discern the presence of man a half mile distant to windward. It

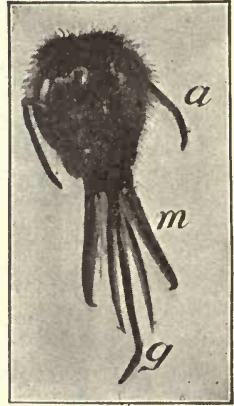

Fig. 344.- Head of the bumblebee. $a$, antenna ; $g$, glossa or tongue used in licking the nectar from flowers; $\boldsymbol{l}$, paraglossa ; $m$, maxillæ. Photograph. 
is probable that a few birds and also fish use the sense of smell in seeking food. The special end organs of this sense in the vertebrates is located in the nucous membrane lining the upper parts of the nasal cavity, whence a pair of nerves convey the stinuli to the brain.

With the exception of arthropods, but little is known concerning the sense of smell among the invertebrates. Many insects have a keen sense of smell. A piece of decaying meat so covered that it can not be seen will, on a warm day, attract numerous flies, some of which apparently scent it at a distance where no odor is discernible to man. Many of the social insects recognize the members of their household by smell, and the male of some species seeks his mate by the olfactory sense. Among insects the organs of smell are located in the antennæ or palps. Male bumblebees with the antennse removed can not find their mates (Fig. 344 ). Some crustaceans seem to possess organs of smell on the antennules.

The sense of hearing is most acute in mammals and birds. The organ of hearing, which is a portion of the internal ear located on either side of the head, responds to certain vibrations productive of sound waves in the atmosphere. It is probable that all normal vertebrates with the exception of some fish and certain tailed amphibians are capable of hearing. In the frog, the large round tympanic membrane back of the eye (Fig. 239) is similar to the tympanic membrane of birds and mammals located at the inner end of a short canal on either side of the head. It transmits the vibrations affecting it to the inner ear, which is an irregular sac filled with liquid, and containing the terminations of the nerve of hearing. No tympanic membrane 
is present in fish, salamanders, or snakes, which fact accounts in part for their partial deafness.

More simple auditory organs are found among some of the invertebrates. These consist of small sacs containing a clear liquid with one or more tiny lime nodules, called otoliths. Specialized cells often bearing vibratile hairs line more or less of the inner surface of the sac. Organs of hearing or equilibration are present in the margin of the umbrella of certain jellyfish, in the head of a few worms, in the foot of the mussel, in the head of the snail, in the first segment of the antennules of the crayfish, and in some other crustaceans in the tail. Hearing among insects is in many species quite acute, and it is probable that they are aware of some sounds that make no impression on our ears. In a few insects a vibrating tympanic membrane occurs as may be seen in the common locust, having the ear on the side of the first abdominal segment. The true grasshoppers and crickets have an ear on the front leg. The oval tympanic membrane may be seen with the naked eye on the outer surface of the tibia of the common large cricket. It has the same location in ants. Certain other insects possess a complex organ of hearing at the base of each antenna.

Sight is undoubtedly the most important sense of all for animals living in the light, because it not only aids them greatly in securing food, but also in escaping from their enemies. All vertebrates have eyes or rudiments of them. Moles living underground, insects, crustaceans, fish, and amphibians inhabiting caves, and some fish living at great depth in the sea have eyes of such a rudimentary character as to be of no use. The larger mammals can sight 
objects at a distance of many miles, but the keenest vision is probably possessed by birds. A fish hawk at a distance of two hundred feet will spy a fish in the stream when human vision can not detect it fifty feet away. The chimney swift, wheeling through the summer air, no doubt, sees the minute insects constituting its food. Most of the lower vertebrates are decidedly shortsighted. A toad does not recognize a fly at a distance of more than two or three feet, and few common fish distinguish food beyond five feet.

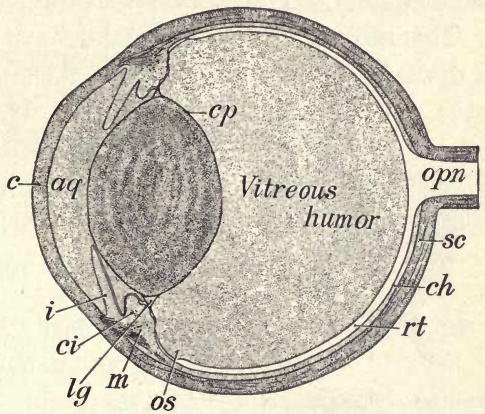

Fig. 345. - Section of the cat's eye enlarged twice. $a q$, aqueous humor; $c$, cornea; $c i$, ciliary processes; $c p$, capsule surrounding the erystalline lens; $c h$, choroid coat; $i$, iris ; $l g$, ligament of the lens; $m$, muscle to adjust the lens for far and near sight; opn, optic nerve leading to the brain; $r t$, retina; sc, sclerotic coat. From Davison's "Mammalian Anatomy."

The structure of the vertebrate eye is admirably adapted for its function. The eyeball is composed of the tough, thick sclerotic coat, the thin black choroid coat, and the pinkish retina almost surrounding the vitreous humor which is separated from the aqueous humor by the crystalline lens adjustable for far and near vision. The parts of an eye of a cat, cow, or fish may be easily seen by cutting it in two with a sharp knife. The structure is especially well shown in an eye frozen before being cut.

Many of the coelenterates, echinoderms, worms, and 
mollusks have no eyes, but they are usually sensitive to light. The simplest eyes are found in the jellyfish, and organs of sight somewhat resembling those of the vertebrates are present in the scallop (Pecten) and cephalopods (squid, cuttlefish, etc.). The snail has well-developed eyes on stalks.

The insects and crustaceans have acute vision, but at a distance of only a few feet. Both compound and simple eyes are present in most insects. If the compound eye of

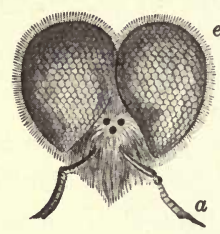

Fra. 346. - Front view of head of bee. $\alpha$, antenna; $e$, compound eye; the three black dots are the simple eyes. a house fly be placed under the low power of the microscope the surface will appear marked off in hexagonal areas. These are the ends of cones, each of which may function as a separate eye. The queen bee has five thousand of them, the drone twelve thousand, the dragon fly twenty thousand, and some beetles twenty-five thousand. The simple eyes, called ocelli, located near the middle of the forehead, are just visible to the naked eye in such large forms as the locust in which there are three. These are probably used for very near vision. Spiders have no compound eyes, but from six to eight ocelli larger than those of insects.

\section{PROTECTION FROM ENEMIES}

Every living animal from the amœba to man has enemies seeking its destruction, and it is only by special adaptations that the species persists. The huge elephantlike Titanotheres and Uintatheres which a few millions of years ago roamed about in Western United States, became 
extinct because they had no means of protecting themselves from the furious saber-toothed tigers and other bloodthirsty carnivores of those days. The buffalo of the westarn plains, the fur seal of Alaska, and the trout of the mountain stream are being overcome in the struggle for

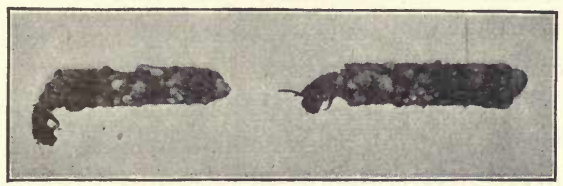

FIG. 347. - Larva of caddis fly. Natural size.

existence, because they have no means of adequately protecting themselves from their arch enemy, man.

Many animals are provided with an external armor preventing the attack of would-be foes. The sea urchins are covered with spines, many of the mollusks are inclosed

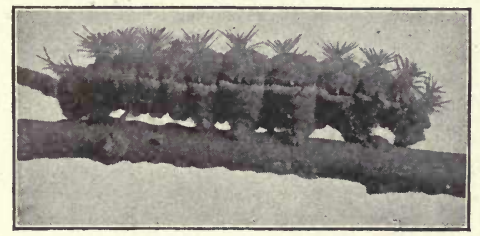

FIG. 348. - Photograph of io, a poisonous caterpillar.

in calcareous shells, some of the marine worms live in hardwalled tubes, and the larvæ of some insects such as the caddis flies dwell in protecting tubes, while many caterpillars are covered with stiff or poisonous hairs. The hard shell of the crustaceans and the adopted home of the hermit 
crab are effective means in reducing the mortality among these forms. The hard shell of the chelonians, the thick skins of the alligator, tapir, and hippopotamus, the series of bony plates covering the armadillo, and the spines of the hedgehog, form armors of great value in the midst of hostile associates.

Special weapons of defense have been developed among some groups, as in the case of the wasps and bees which prevent the robbing of their homes and the killing of the young, by the use of poisonous stings. Men have been known to die as the result of an attack by a colony of bees. The tarantula and tropical centipeds protect themselves

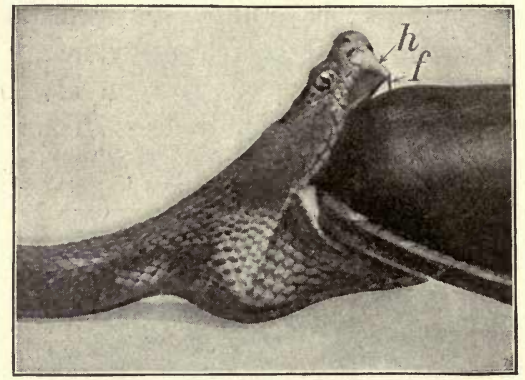

FIG. 349. - The rattlesnake defending itself against an enemy. $f$, poison fang; $h$, hood holding the tooth against the roof of the mouth when not in action. Photograph of posed dead snake. One third life size.

by attacking the enemy with their poisoned mandibles, while the scorpion releases itself from its tormentor by applying its poisonous fang at the end of the tail. The torpedo, a flat-bodied fish of the Atlantic coast, and the six-foot electric eel of the South American waters give a 
severe electric shock to any foe daring to touch them. Some of the catfish possess poisoned barbs in the thoracic fin which are used in contests. A few of the snakes have a pair of long teeth, called fangs, in the upper jaw, through which they inject into any creature disturbing them a deadly poison. The rattlesnakes, copperhead, and southern moccasin are the only poisonous snakes to be feared in our country.

Among mammals the weapons of defense are varied. The antlers of the deer and the horns of the cattle are often used with telling effect against their foes. The tusks of

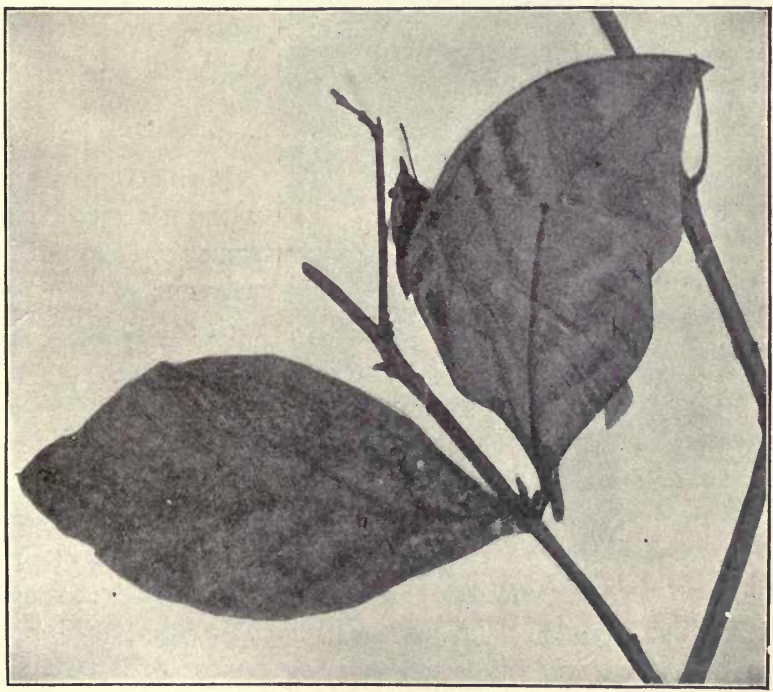

FIG. 350. - Kallima butterfly on the right, leaf on left. Photograph life size. 
the elephant render him a formidable opponent. The long sharp incisors of the rodents and the pointed teeth of the bats afford them sufficient aid in contests with larger animals. The large canines of the camivora and the strong

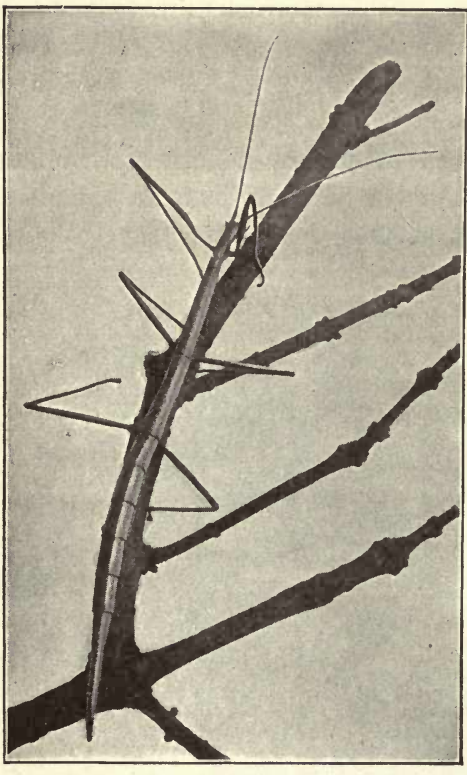

FIG. 351. - The walking stick (Diapheromera femorato). Natural size.

sharp claws of the lion and tiger are weapons of great power. Some of the carnivores, especially the skunks, protect themselves by the ejection of a n auseous-smelling fluid detested by dogs, foxes, and wolves.

Many animals without a protective armor or special weapons of defense seek safety in flight. Such are the hares, kangaroos, and some birds. Others escape by assuming such attitudes and colors as to make it difficult for their enemies to distinguish them from the surrounding objects. The leaf butterfly (Kallima) of India when at rest on certain bushes is so similar to the leaves that even the birds fail to distinguish the difference. The 
katydids, so numerous in late summer, have a green color and venation of the wings, making them so inconspicuous among the green leaves that the birds seldom detect them unless they move. The walking stick insects resemble so closely the twigs of the trees among which they live that only the acutest vision spies the creatures so long as they remain motionless. I have known as many as twenty locusts to sit in the grass within the range of distinct human vision and yet be invisible until they were disturbed. Such protective resemblance prevents the birds and other enemies from exterminating the species.

The measuring worms, larvæ of geometrid moths, imitate so closely the short rough twigs that I have had to touch the suspicious object with my hand before I could be quite sure that it was really an animal. Many of the green larvæ feeding on green foliage escape the eyes of their pursuers because of their protective colors. Some of

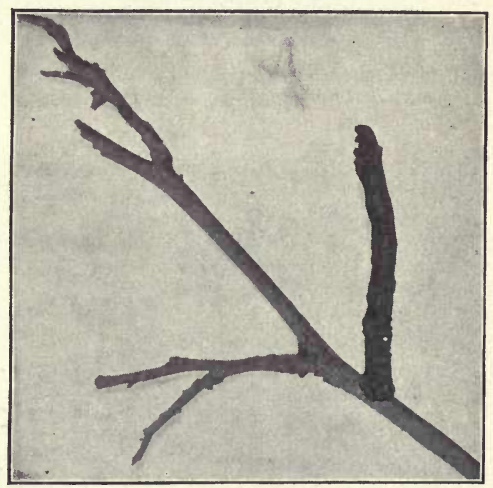

FrG. 352. - The projection on the right is a geometrid larva. Photograph life size. the crabs take on the somber color of the rocks and stones among which they dwell, and sometimes bear on their shells growths of seaweed and hydroids. Spiders 


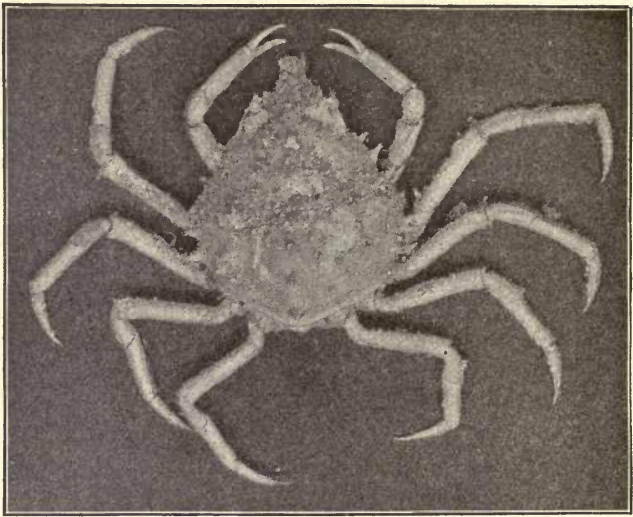

FIG. 353. - Spider crab often found covered with seaweeds and hydroids so as to appear like a stone or stick. Photograph by Overton. One third natural size.

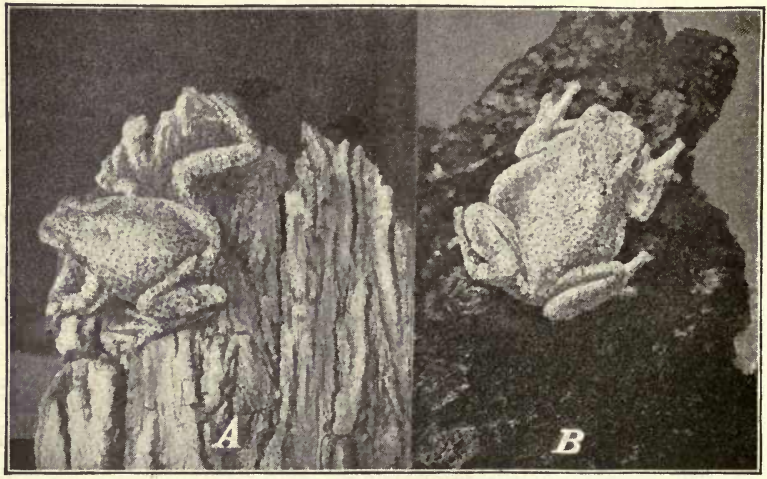

FTG. $354 .-$ Tree frog. $A$, after assuming a protective color; $B$, before assuming the dark protective color of the bark which it took on fifteen minutes later. Photograph nearly half life size. 
in Java resemble so closely bird droppings that a trained eye can not detect the difference unless at close range.

The markings of many fish are such as to harmonize so completely with the variously colored bed of the stream that the casual observer will not see them when only a few feet distant in clear water. The tree frog is a notable example of the ability of an animal to adapt its color to its environment. It is able to change its color from a very dark hue to a very light one in about twenty ininutes, and so perfectly does it agree in color with the surface of a stone, a lichen, or the bark of a tree that often one is not aware of its presence until he has accidentally placed his hand on it. The common frogs are likewise protected by the ability to change the color of the skin. Certain lizards and snakes render themselves very inconspicuous by taking advantage of protective coloration.

A woodcock on her nest has been known to have so much faith in the protection afforded her by the brown-

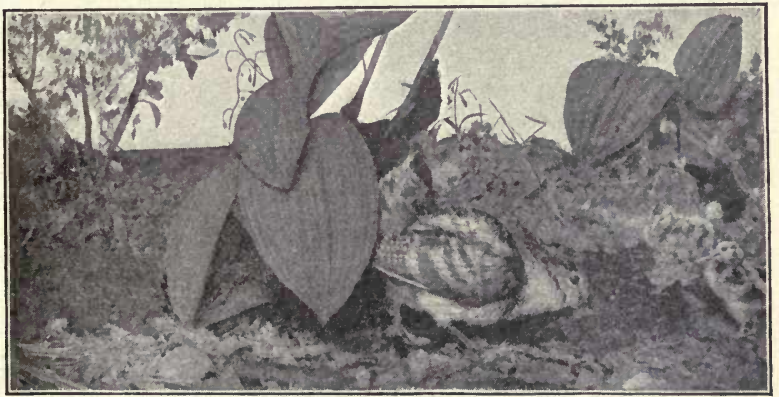

FrG. 355. - Adult woodcock and two young rendered inconspicuous by their env?. ronment. Photographed in American Museum. 


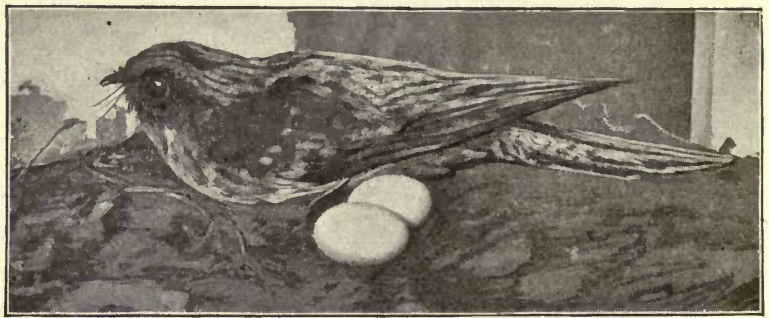

FıG. 356. - The whip-poor-will showing protective coloration. Photographed in the Academy of Natural Sciences, Philadelphia. One third life size.

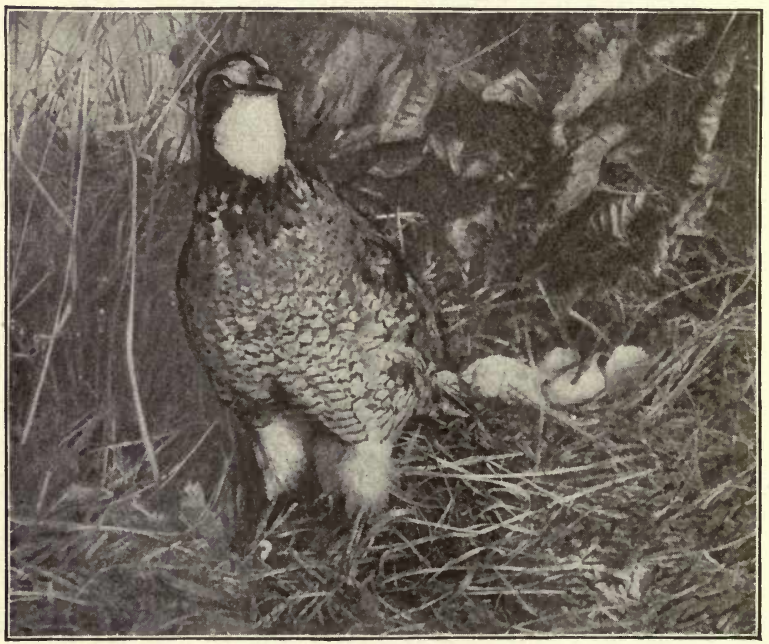

FIG. 357. - Protective resembiance in the bobwhite. Photographed in the Academy of Natural Sciences. 
leaf plumage of April that she would permit a person to approach within a foot or two of her nest. A light snowfall occurring a few days later made the same bird con-

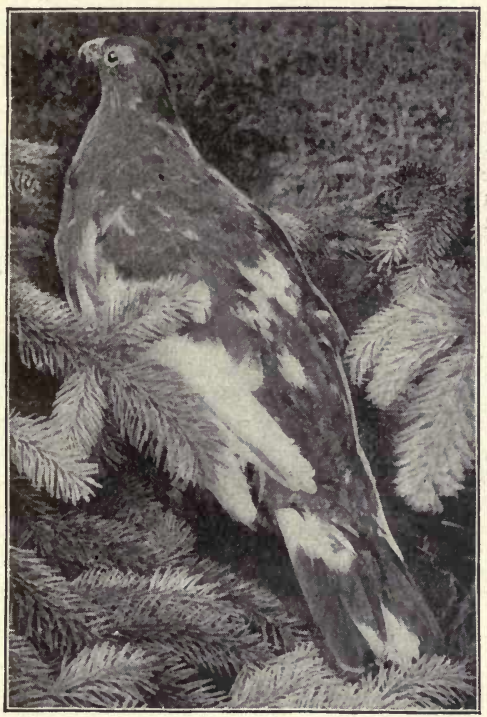

FiG. 358.-The ptarmigan in summer. Photograph of mounted specimen. One third life size.

spicuous, and she would fly from her nest before the observer was nearer than fifty feet. The whip-poor-will as it sits among the dead leaves in the depth of the forest appears not unlike a mass of leaves some of which are browner than others. The hunter, standing within ten feet of a 
large flock of quail, can not see a bird until it flies, because the dull-colored plumage so effectually resembles the autumn leaves and tangled grass. The little screech owl with his gray and brown feathers becomes inconspicuous against the somber-hued barks of the forest. The ptarmigan adjusts its plumage in accordance with the season,

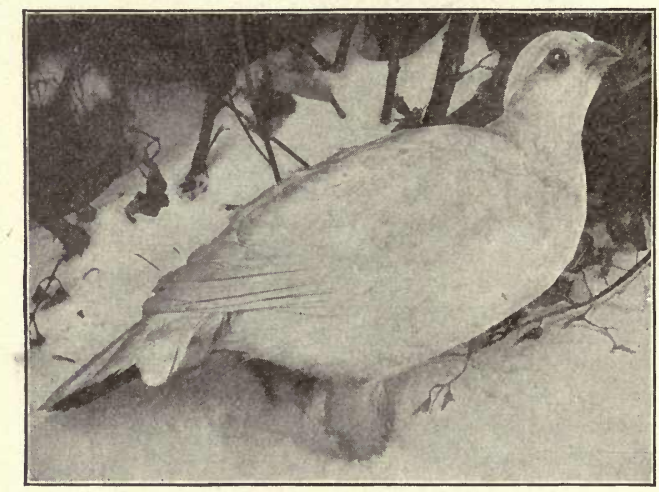

FrG. 359 - The ptarmigan in winter. Photograph of mounted specimen.

being brown in summer and white in winter. The arctic fox and hare exhibit the same seasonal change. Most animals of the arctic regions are white, as that is the most protective color for the land of snow. The weasel in the northern part of the United States and Canada is brown in color during the warm months, but becomes after snowfall in early winter a pure white, except the tip of its tail.

Some animals are protected by their likeness to the form of others which for various reasons are left unharmed. 
This phase of protective coloration is known as mimicry. Certain flies resemble the stinging bees so closely that one must catch them before he can be quite sure of their identity. Some butterflies have wings like those of a few species which are left untouched by the birds because

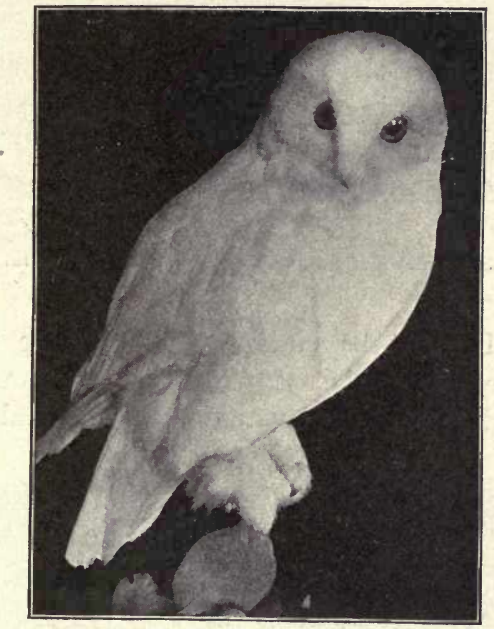

Fra. 360.- The snowy owl visiting the United States only in winter. Photograph of specimen mounted by Neal. One sixth life size.

of their bad flavor. The spotted adder (Fig. 248), a common harmless snake, when disturbed by an enemy coils and vibrates the end of its tail much after the fashion of the rattlesnake.

Were it not for protective coloration and mimicry among animals certain species would doubtless have suffered ex- 


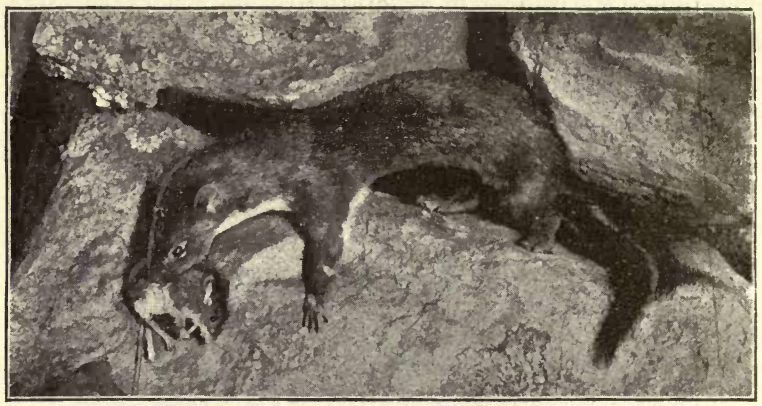

FIG. 361.-The weasel in summer with its prey, the mouse. Photographed in the American Museum of Natural History. One sixth natural size.

tinction. It must be understood that these characteristics are secured to the species, not by its own will power, but through a process of variation and natural selection.

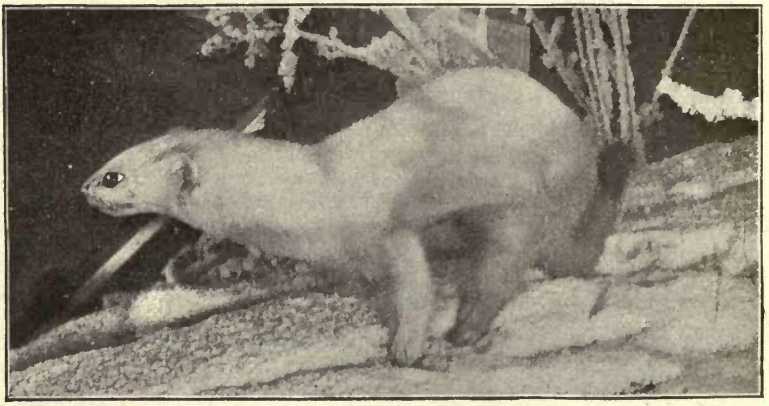

Fic. 362. -The weasel in winter. Photographed in the American Museum of Natural History. 
During many years in the past those which did not possess protective features were killed by the ever-pursuing enemies, while the survivors transmitted to their offspring their special protective characteristics.

\section{PARASITISM}

Symbiosis. - There are certain species of animals which are always found in association with certain other species, because in the struggle for existence they are mutually helpful. The ants are often to be seen in company with the plant lice which feed on the sap in the tender twigs and leaves. From the alimentary canal of the plant lice exudes a sweet fluid much sought after by the ants. The ants assist the lice by transporting them to the tenderest parts of the plant, and in some cases during inclement weather even remove them to places of shelter. This condition of intimate association for mutual benefit is known as symbiosis. Some of the crabs bear on their back sponges which render them less easily visible to their enemies, and the crab repays the kindness by carrying the sponges to good feeding-grounds.

True Parasites. - A still closer association between species, where only one derives any benefit, represents a condition designated parasitism. The animal which thrives by feeding on the living blood or tissue of another called the host is a parasite. Parasitic animals are found among nearly all the sublkingdoms, but they are the most numerous among the protozoans, worms, and arthropods. Only about a dozen species of vertebrate parasites are known. They are the lamprey eels (Fig. 215) and hagfish, which 


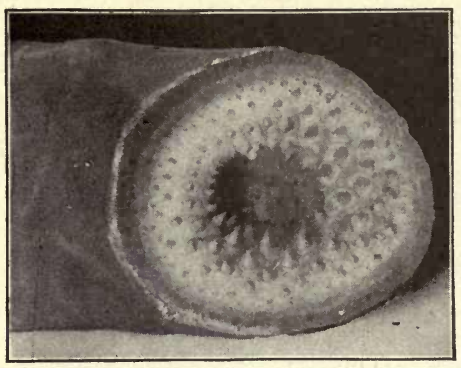

FIG. 363.-Photograph from life of the mouth of the lamprey ecl sucked fast to a piece of glass. Natural size. become the guests of other fish whose blood and mucus they suck by attaching to their sides.

Parasitic Protozoa. - Among the Protozoa, the commonest parasites are the Amobadysenterica, inhabiting the intestine of man and causing one kind of dysentery; the Plasmodium malarioe, residing in the human blood corpuscles and producing malarial fevers; the Opalina, of which hundreds are present in the large intestine of the frog, and the Gregarina, abundant in the alimentary canal of the earthworm, lobster, and many beetles.

\section{Parasitic Worms.}

- Of parasitic worms there are more than a hundred species, most of which live at the
FIG. 364.-The malarial parasite photographed through a microscope magnifying one thousand diameters. 'Two individuals are present in the red blood corpuseles.

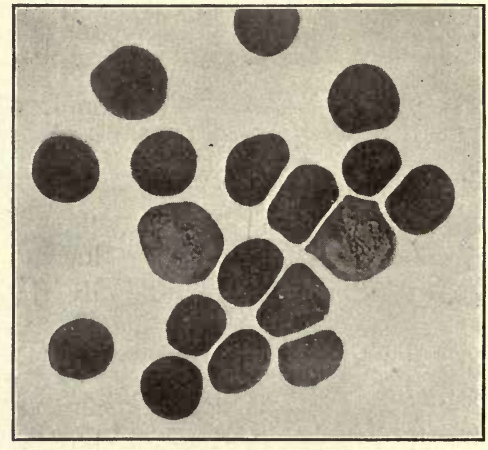


expense of the vertebrates. The most dreaded of the round worms is the Trichina living in the flesh of hogs, rats, dogs, and man. One animal becomes infected by eating the flesh of another containing the parasites which upon reaching the stomach of the new host bring forth many young ones. These migrate through the walls of the alimentary canal into the muscles and remain there in a living condition many months, never again becoming active until eaten by a new host. The government meat inspectors have found as many as seventeen thousand hogs containing this parasite in one year. A microscopic worm, Filaria, occurring in the blood of man in the tropical regions, produces various disorders. Among the larger parasites is the stomach worm, Ascaris lumbricoides, from three to six inches long, affecting children, and various other species of Ascaris are common in nearly all mammals. They hold on to the mucous coat of the stomach or intestine by means of a hook at the hind end, and feed on the digested food. Eggs are produced at the rate of about fifteen thousand daily, and passing out with the excrement may reach the water

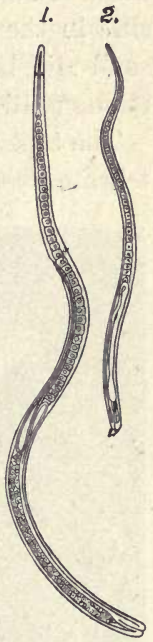

FIG. 365. - Trichina. 1, female ; 2, male. Enlarged fifty times. supply and infect new individuals. Strongylus is a genus containing many species of minute, round worms parasitic in the mammals, birds, and frogs. Some kinds occupy the digestive system while others are present only in the respiratory organs. Nine out of every ten cats harbor round worms of some kind. 
The flat worms are parasitic in all classes of vertebrates. The liver fluke, annually causing the death of thousands of sheep in Great Britain and South America, inhabits the bile ducts in its adult stage, while during its early development it swims free in the water and later becomes parasitic in the pond snail. After a time it escapes from the snail and becomes encysted on a grass blade, where it remains until eaten by the sheep.

The tapeworms, various species of which inhabit the vertebrates from fish to man, attain the largest size of any of

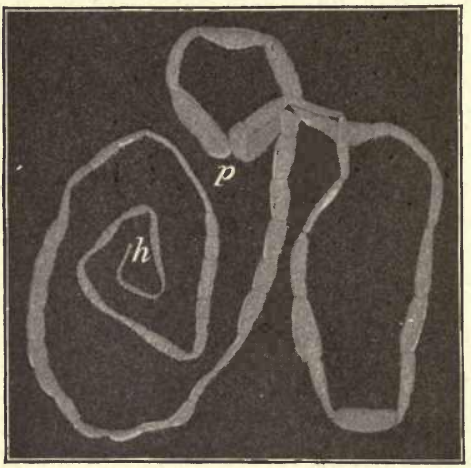

FiG. 366.-A tapeworm from the cat. $h$, head; $p$, posterior end. Nearly life size. the parasites, specimens having been reported over fifty feet in length. They are characterized by a small head (scolex) bearing hooks or suckers for anchorage in the wall of the alimentary tract, a tapelike body composed of numerous segments, called proglottides, and the absence of a digestive canal. They are nourished by the absorption through their body walls of the digested liquid food of the smaller intestine. The eggs, which the worms mature by the thousands daily, can not develop within the host, but pass out, and upon being taken in with food or drink by certain animals hatch into spherical forms with six 
hooks. Very soon each one migrates from the alimentary canal to the muscles, liver, or peritoneum, and forms about itself a sac or cyst, and is then known as a cysticercus. Before any further growth can occur it must reach the alimentary canal of the same species as that in which its parent lived. Tonia solium, a tapeworm occasionally present in man, passes its larval stage in the flesh of the pig, while the cysticercus of the other human tapeworm is found in beef. In some regions one out of every five rabbits contains the cysticerci of the dog's tapeworm in the liver or peritoneum. They are oval white bodies from a fourth of an inch to half an inch in diameter. It is also quite easy to find the cysticerci of the cat's tapeworm in the liver of the mouse.

Parasitic Arthropods. - The protozoans and worms are all internal parasites, but among the arthropods are

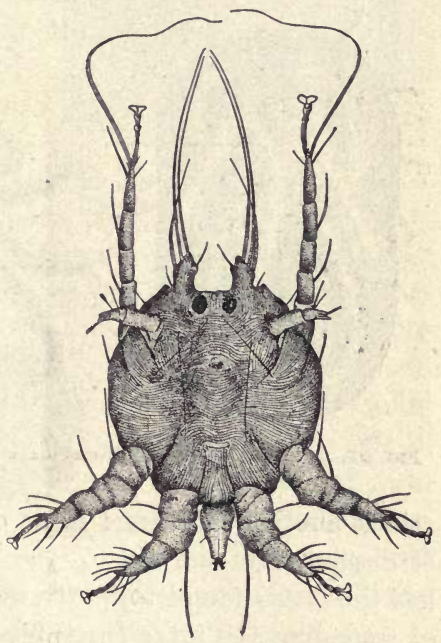

F1G. 367. - The mite producing sheep scab. Much enlarged.

found both internal and external feeders. To the latter group belong most of the mites and ticks of the class Arachnida. The hair mite (Fig. 150) is common in 
human oil glands supplying the hair. The microscopic itch mite buries itself beneath the skin and causes the disease of itch. Several other species of mites affect the domestic animals and cause the falling out of the hair and other disturbances.

The cattle tick (Boöphilus bovis) affects the cattle of the Southern states, Mexico, and Cuba. Like many external parasites, it sometimes leaves one victim to
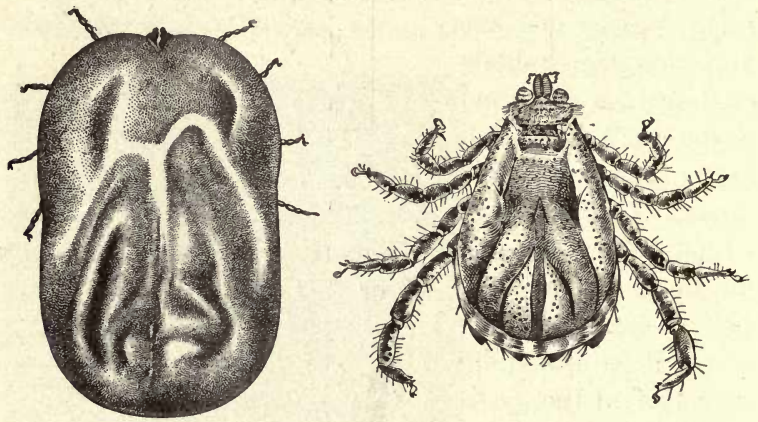

FIG. 368. - The cattle tick, female and male. Much enlarged. After Howard.

attack another later, and in so doing transfers the germs of disease from the sick to the healthy. The cattle tick has thus been found to be the chief if not the only means of spreading the fatal Texas fever among herds of cattle, and it is on this account that all cows shipped north must first pass through the dipping tanks of petroleum or other insecticidal liquid. Several species of ticks affect the domestic animals.

The lice, of which there are more than forty species 
living on birds and mammals, differ from the true mites and ticks in having only three pairs of legs, and the body is divided into three parts characteristic of all insects. Because of their parasitic habits the wings have been lost. They secure their food by sucking the blood or by feeding on the hair and feathers.

Only three species affect man.

The bedbug and many of the fies are what may be termed temporary parasites as they are present on the host only at intervals. Among the fleas, Pulex irritans is the one

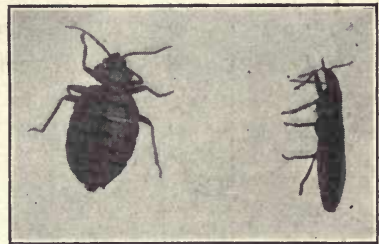

FIG. 369.- Bed bug. Side view shows the piercing beak. Photograph twice life size. annoying the dog, cat, and man. The eggs are often laid on the hair of the cat or dog and the slender wrig-

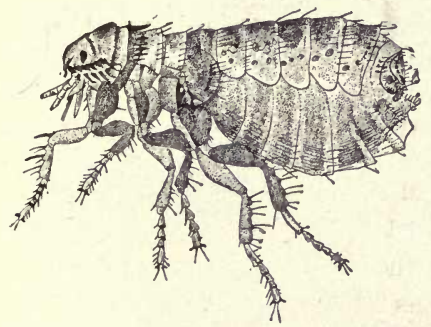

FTG. 370.- Cat and dog flea enlarged fifteen times. After Howard. gling larvæ live in the dirt filling the cracks of the floor or similar places. The female of several species of mosquitoes attacks all warmblooded animals and often conveys to man serious diseases, such as malaria, filariosis and yellow fever.

Many insects are parasitic during their larval life, but independent during the adult stage. The larvæ of several species of botflies dwell during the larval state either in 
the alimentary canal or just beneath the skin of the mammals. The young of the horse bot dwell in the stomach,

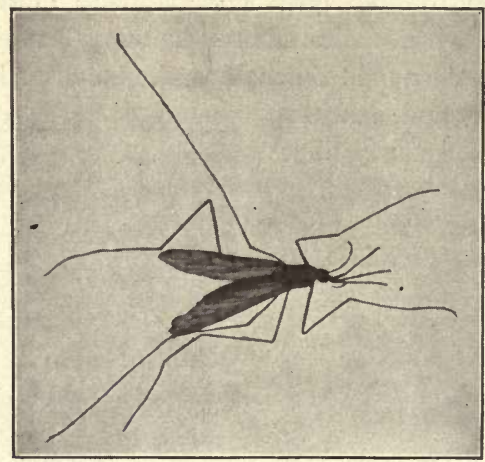

FIG. 371.-Anopheles, the parasitic mosquito, infecting man with the malaria germ. Photograph enlarged three times.

while those of the cow migrate, as soon as hatched, from the alimentary canal to the back, just beneath the skin, through which they make holes to breathe and later escape.

All of the ichneumon flies, of which there are more than a thousand species, are parasitic in other insects during the larval state. Their presence usually means death to the host. They are, therefore,

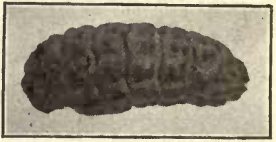

Fig. 372. - Larva of the ox bot (warble) removed from beneath the skin of the back. Photograph life size.

of great service in keeping in check harmful species, such as the cabbage worm, tussock moth, fall webworm, and cotton caterpillar. Out of a hundred larvæ of moths and 


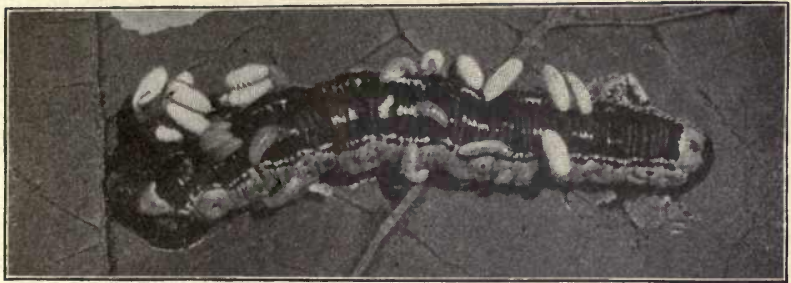

FIG. 373. - Larva of the Catalpa sphinx moth from which are issuing the larva of ichneumon flies. The white ovoid bodies are the cocoons in which the larvæ transform to adults. Over a hundred parasites were present in this host. Photograph about life size.

butterflies collected in late summer or autumn nearly one half will usually be found to contain the parasites of either the ichneumon or chalcis flies.

The chalcis flies are small, and some species deposit their eggs on the skin instead of within the insect, and

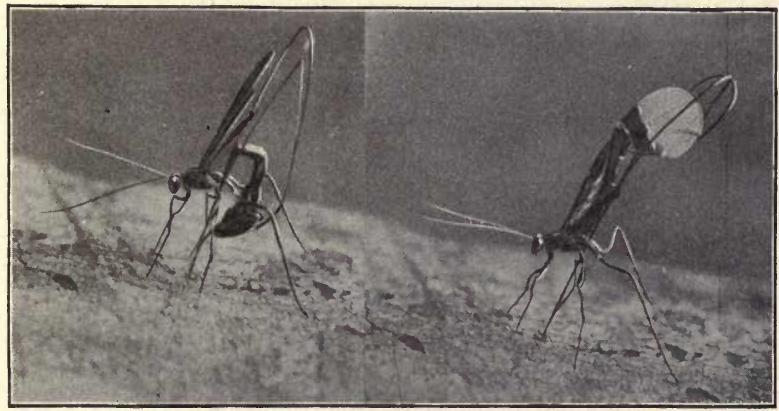

FIG. 374. - Thalessa, an ichneumon inserting its two-inch ovipositor in a beech tree to lay an egg in the burrow of the horn tail, a wood borer upon which the young ichneumon will feed. The two curved hairlike supports steady the ovipositor. Photograph. 


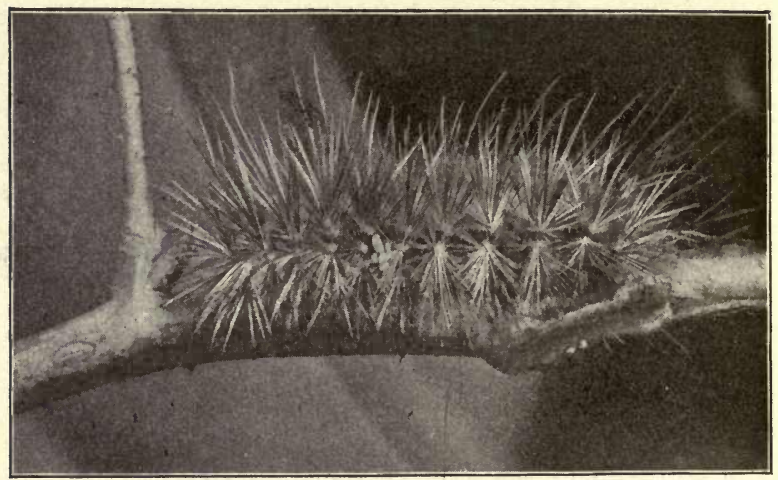

Fig. 375. - Five larvæ of a chalcis fly in a bunch on a caterpillar. Photograph nearly twice life size.

certain species parasitize the eggs of the harmful insects, thus rendering great service. Tachina flies aid in the good work also. Their minute eggs are glued to the skin of the host separately (Fig. 26).

In cases where the young live an independent life and the adults are parasites, marked degeneration often occurs, which is especially noticeable among the crustaceans. Sacculina exhibits in youth the characteristic features of its order, but after becoming a parasite on the crab in

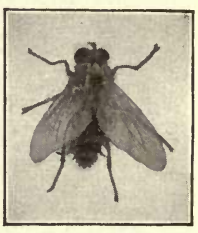

FIG. 376. - A Tachina fly. Photograph slightly enlarged. later life, the legs, eyes, and mouth parts are entirely lost and it absorbs nourishment from its host by numerous delicate, rootlike suckers. Other peculiar crustaceans, known 
as fish lice, live as parasites attached to the gills or external surface of fish and other aquatic forms. Of these the Lerneans are most remarkable in respect to degeneration. They occur on all aquatic creatures from the colenterates - and echinoderms to the whales. Out of a dozen codfish I examined on the Maine coast, eight contained one or

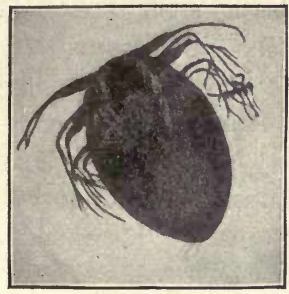

FIG. 377. - Nauplius or larva of Lernea branchialis. Photographed through the microscope.

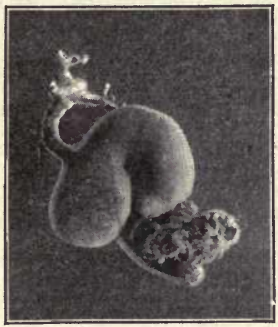

Fig. 378. - Adult female Lernea branchialis. The branched process at the left enables it to hold fast in the gills. Photograph life size.

more individuals of Lernea branchialis embedded in the gills. The male of this species leads an independent life.

This brief discussion of parasites shows that but few, if any, of the species above the protozoa are exempt from having their bodies made the feeding ground for smaller creatures. If certain species of insects occur in vast numbers one season, few will be present the following year owing to destruction by parasites. The life of these paupers means death to many of their hosts, and so large a part do they play in the world of physical life that Dr. Smith says, "Without them there would be no possibility of an existing vegetation." 


\section{VANISHING SPECIES}

The fossil remains of animal life embedded in the rocks testify that more than fifty thousand species have vanished within probably thirty million years. The stone records indicate that during the ancient past no one species survived longer than two or three million years, while some may have existed only a few thousand years. In the earth's youth, the comparatively rapid changes in climate, soil, and food, together with the appearance of new enemies, made it necessary that any species to win in the struggle for existence should change its habits and structure to harmonize with its environment. The penalty for failure to do this was extinction. There is a continual warfare in nature not only between certain different species, but also among the individuals of the same species. Of the one hundred or more spiders hatched from the eggs in a cocoon only a few attain full size, the weaker being eaten by the stronger. Of the million eggs deposited by a shad, probably less than a score give rise to adults, as many will die from lack of food and others must go to satisfy the carnivorous appetite of larger fish. Of a dozen quail reared in a single nest, only a few of the more hardy and wideawake will be able to endure the rigorous winter and escape the ever-pursuing enemies. The fulmar petrel is one of the most abundant of birds in certain regions of the seas, but the female lays only one egg yearly. It has scarcely any enemies. Rabbits, though producing three litters of from four to six each in a season, are on the decrease in the Eastern States, owing to the presence of 
so many foxes, dogs, mink, men, and raptorial birds. In the Western States the rabbits have lately increased to such an extent that public drives or hunts are arranged, by which as many as twenty thousand are taken in a single day. This increase is due to the fact that the wolves and coyotes, which formerly preyed on the rabbits, have year by year had their ranks lessened by the shotgun, the trap, and poisoned bait. In parts of New Zealand, where carnivorous animals are few, the imported rabbits have multiplied to such an extent as to consume all the grass, thereby causing the sheep to starve to death. Thus the ascendency of one group of animals often means the disappearance of another. This is especially true of the introduction of a parasite into a new country where the hosts have not become more or less adapted to withstanding its attacks. The smallpox germ introduced into Iceland in 1734 killed more than half the population, and almost equally fatal results occurred when the disease first visited Greenland.

It is therefore evident that the extermination of a species depends on several factors, most important of which are the presence of numerous enemies and the lack of proper food. During the age of man, including perhaps not much over a hundred thousand years, several species of vertebrates have become extinct, among which are the huge mammoth (a near relative of the elephant), Steller's sea cow, the great auk, and the moas or giant birds of New Zealand.

In 1871 Colonel Dodge drove for twenty-five miles along the Arkansas River through an unbroken herd of buffalo. Millions of these noble animals fed on the western plains. A few years later the completion of the Northern Pacific 


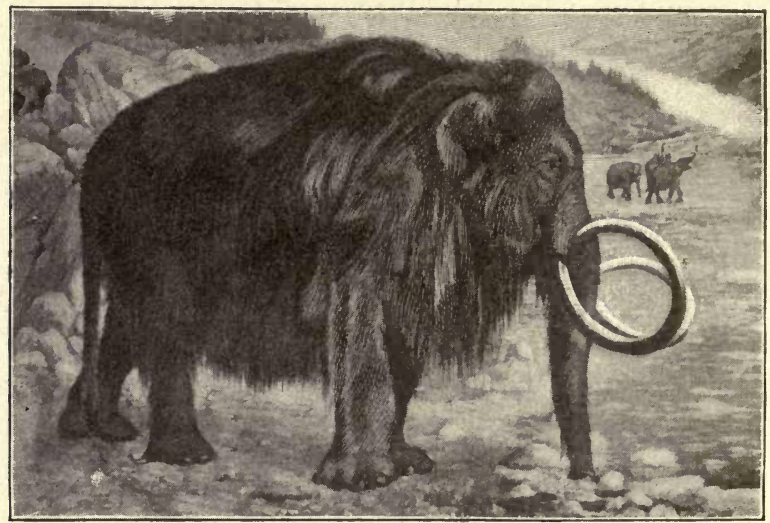

FrG. 379. - The mammoth, the ancestor of the elephant. From a painting by Knight in the American Museum of Natural History.

Railroad brought the hide hunter to the grazing grounds, and by 1883 scarcely a thousand buffalo were in existence. Congress has many times failed to do its duty in enacting proper laws for the preservation of our animal wealth.

Until a half century ago moose were abundant in the Adirondacks and many other wooded regions in the northern states, but the ceaseless slaughter continuing for years unchecked has exterminated the species in most of the states except Maine, Wyoming, Idaho, and Minnesota. The prong-horned antelope has been saved from utter destruction in most of the states it inhabits by the enactment of proper laws. In Routt County, Colorado, it is estimated that only about fifty antelope survive, while fifteen years ago there were nearly fifty thousand. In the 
same State, the mule deer is said also to be on the verge of extinction. Any animal valuable for flesh, fur, or feathers is destined to be one of the vanishing species unless protected by law from its great enemy, man. The beaver, celebrated for its architectural skill and intelligence, has fled from most of its former haunts in the Eastern and Middle States, and now exists only in small numbers from the Rio Grande in Texas northward to the limit of trees, and southeastward through Canada to New England. The fur-bearing Alaska sea lion, wrongly called seal, which for many years furnished more than a million dollars' worth of sealskin annually, will within another decade become so few as to be of little com-

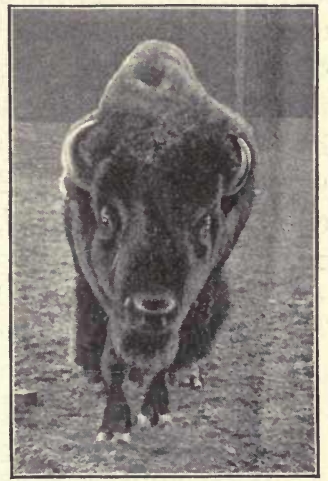

Fig. 330.-The butfalo (bison). Photographed in the Philadelphia Zoölogical Gardens.

mercial value unless the killing of mothers at sea is stopped. In 1873 a special agent of the government estimated the number of seals living on the Pribilof Islands to be over three millions. In 1890 the number was considered to be less than one million, and in 1903 a careful investigation showed that only about two hundred thousand were yet living.

Not only mammals, but likewise birds and fish, are vanishing before the terrific slaughter of man. The woodcock, wild turkey, prairie chicken, and wild pigeon abounded in many regions a quarter of a century ago. To-day the 
woodcock have deserted entirely many of their former feeding grounds east of the Mississippi, and are scarce everywhere. The wild turkey survive only in a few heavily timbered regions in Florida, Virginia, Pennsylvania, Texas, and perhaps one or two other States. The prairie chicken, once so numerous on the western plains, can not last much beyond another decade, and the wild pigeon was thought to be practically extinct in 1899 , but a few scattered flocks have since been discovered. The enormous numbers of pigeons present in the Eastern States forty years ago is clearly shown by Audubon's description of them as observed in Kentucky.

"Let us now inspect the places of nightly rendezvous. ... My first view of it was about a fortnight subsequent

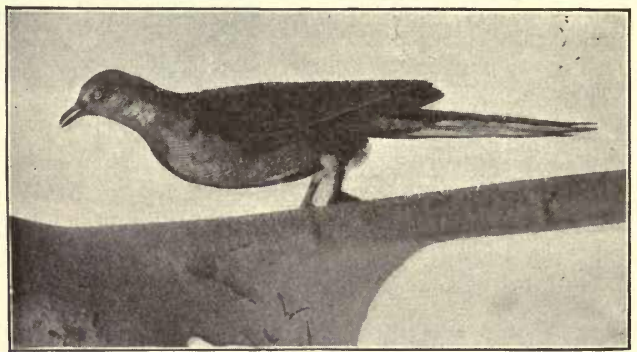

Fig. 381.-The wild pigeon (Ectopisteus migratorius). Photographed in the Academy of Natural Sciences, Philadelphia. One sixth life size.

to the period when they had made a choice of it. . . . As the period for their arrival approached, their foes anxiously prepared to receive them. . . . The sun was lost to our view, yet not a dozen had arrived. Everything was ready, 
and all eyes were gazing on the clear sky, which appeared in glimpses through the tall trees. Suddenly there burst forth a general cry, 'Here they come.' . . . Thousands were soon knocked down by the pole men. The birds continued to pour in. The fires were lighted and a magnificent as well as wonderful and almost terrifying sight presented itself. The pigeons arrived by thousands, alighted everywhere, one above another, until solid masses as large as hogsheads were formed on the branches all around. Here and there the perches gave way under the weight with a crash, and falling to the ground destroyed hundreds of birds beneath, forcing down the dense groups with which every stick was loaded. It was a scene of uproar and confusion. I found it quite useless to speak or even to shout to those persons who were nearest to me. Even the reports of the guns were seldom heard, and I was made aware of the firing only by seeing the shooters reloading.

"No one dared to venture within the line of devastation. ... The pigeons were constantly coming, and it was past midnight before I perceived a decrease in the number of those that arrived."

The investigations of Hornaday, as cited in a previous chapter, show that many species of birds are being so persecuted by the egg hunters, the small boy, and the cat, that their numbers have been lessened one half within fifteen years, and soon we may expect several species to become extinct unless through education public sentiment is changed.

The supply of alligators has decreased about ninetyeight per cent since fashion smiled on belts, pocket-books, and hand bags made of alligator hide. If the demand for 
tortoise-shell articles continues on the increase another decade or two, the hawkbill turtle will share the fate of the buffalo. The salmon, trout, and lobster, once supplying millions of dollars' worth of fine food annually, are reported to be decreasing in an alarming manner owing to the recklessness with which lax laws permit them to be caught. Of the twenty-eight rivers formerly inhabited by the salmon, only eight now contain them, and in one district where in 1896 three hundred thousand cases of

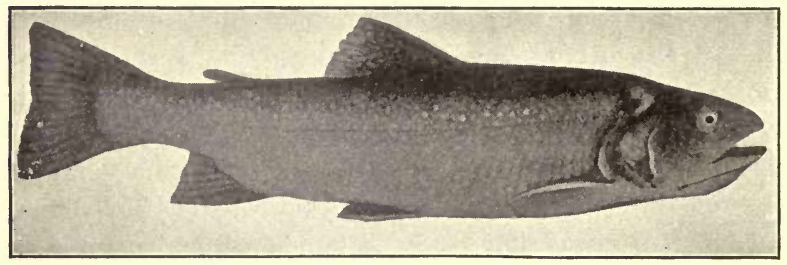

FIG. 382.-The brook trout.

salmon were put up, scarcely any fish were taken three years later. While the brook trout will probably always be cultivated in ponds, where its finer qualities degenerate, there is scarcely a possibility of its continuance in the unprotected forest streams longer than a decade or two.

The government authorities of the various states as well as of the United States within recent years have become aware of the fact that in order to preserve the vast wealth of our country represented by wild animal life, stringent protective laws and an enlightened public sentiment must be created. The recreation and sport afforded by the legitimate hunting of wild game is a great conserver of 


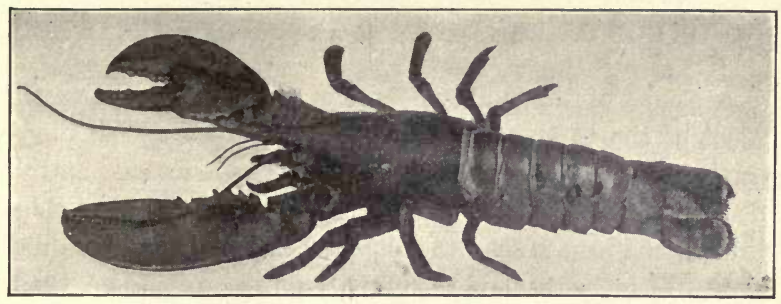

FIG. 383. - The lobster. Photograph one flfth life size.

nervous energy, and when statistics show the millions of dollars bound up in the untamed fish, fowl, and beast, there can be no doubt about the wisdom of spending a large amount of money to maintain this wealth in forest and stream. The value of our fish products annually is fully fifty million dollars. The annual government appropriation for the maintenance of the fish industry is a half million dollars. From July, 1901, to July, 1902; the bureau of fisheries distributed eggs and young fish to the number of $1,414,523,374$. In addition, $81,020,000$ young lobsters were planted in favorable localities along the seacoast. Thus by the aid of the State and the United States Fish Commissions hundreds of streams have been stocked with trout, bass and other game fish, and lobster fishing has been made a productive industry in many regions along the coast.

When boys and girls as well as men and women realize that every act tending toward the preservation of our beneficial wild animals manifests true patriotism, history will record a full century without the extinction of a single valuable species of animal life. 


\section{ORIGIN OF THE DIVERSE FORMS OF ANIMAL LIFE}

A study of the universe and of the rocks forming the crust of the earth shows that conditions were such many millions of years ago that no life could have existed on this planet. It is therefore evident that living things at some time in the past must either have been developed from lifeless material or reached the earth from some other heavenly body. Scientists find no evidence in favor of the latter theory, and we are therefore forced to believe that at some period after the surface of the earth became cool, spontaneous generation occurred, i.e., a particle of lifeless earth was transformed into a living thing.

The conception of the ancient as well as some of the more modern philosophers in regard to the origin of animals is entirely erroneous. Aristotle held that some animals spring from putrid matter, that certain insects develop from dew, that worms originate in the mud of wells, that fleas arise from very small portions of corrupted matter, and bugs proceed from the moisture on animal bodies, and lice from the flesh of other creatures. Van Helmont, of the seventeenth century, gives detailed directions for creating mice out of wheat and stagnant water. The learned Alexander Ross, about the year 1700, declares there is no doubt that worms are generated from cheese and that butterflies, locusts, grasshoppers, snails, eels, and such like originate from putrid matter.

Before the days of the compound microscope and careful scientific research, spontaneous generation was thought to be going on continually, but by numerous carefully conducted experiments of Spallanzani, Schultze, Schwann, 
and Pasteur it was demonstrated about fifty years ago that spontaneous generation does not occur under present conditions in this world. All animals originate from their parents by means of fission, spore formation, budding, or

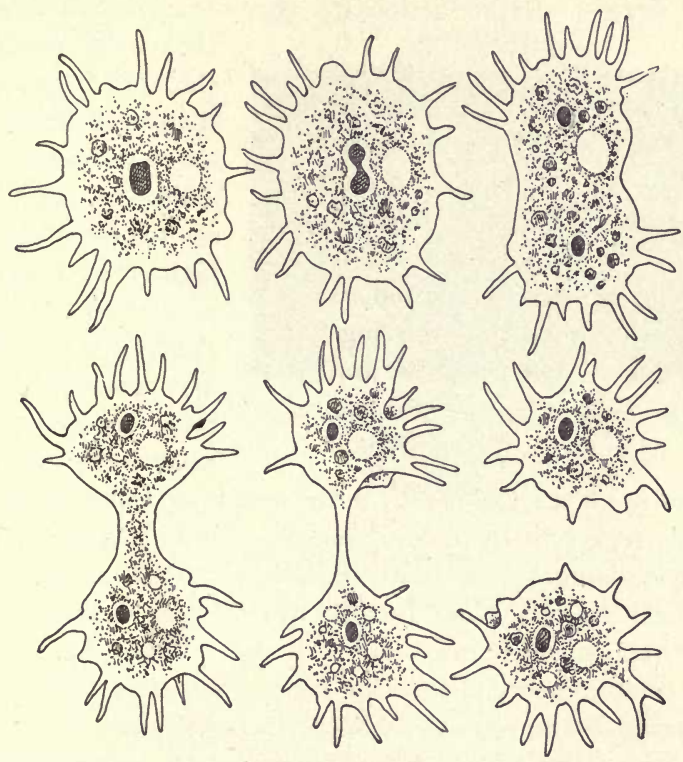

FrG. 384. - Amœba showing formation of two animals from one by fission.

eggs. Fission, consisting in the division of the animal into two parts, is common among the Protozoa and occurs in a few species of worms. Spore formation may be seen in some of the Protozoa, such as the malarial parasite, in which case the animal forms a cyst or thick coat around 
itself and divides into several fragments. The cyst then burst, and each fragment or spore becomes a separate animal. As noted in a previous chapter, budding takes place in the hydra and many other cœlenterates and in a few worms. Reproduction by eggs occurs in all species

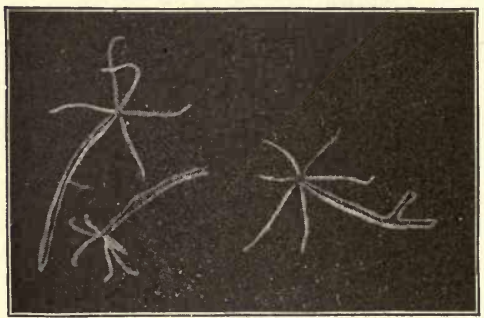

FIG. 385. - Photograph of living hydras; a bud is present on tro of them. above the protozoans. The eggs and spores of some of the microscopic animals are so small as to require very high magnifying power to define them clearly, and when dry are capable of being carried about inthe air by currents thereby gaining access to open vessels of water or other fluids suited to their development. Until fifty years ago people thought that broth or milk boiled in an air-tight jar sometimes spoiled because particles of the materials were transformed into minute living bodies. At present it is well understood that the life in the sealed and heated jars was due to minute germs or spores of plant life, called bacteria, some of which are not killed by being boiled a half hour.

Up to the present time nearly a half million different kinds or species of animals have been described, and more than a hundred new species are discovered every year, so that it is probable that there are no less than a million species of animals dwelling on this planet. That a pair of 
each of these was created direct from lifeless material seems very improbable, though until 1859, when Charles Darwin published his "Origin of Species," this was generally believed. The Bible describes briefly the creation of the various groups of animals on several successive days. These days instead of being twentyfour hours, as formerly understood, are now considered to have been long periods of time, each equaling several million years. The earth's surface was once entirely covered with water holding in solution or suspension large quantities of min-

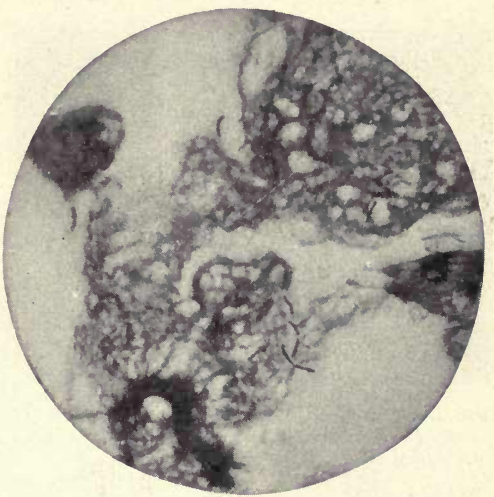

FrG. 386. - Bacteria causing consumption (tuberculosis); six or seven germs resembling minute rods are present. Photograph magnified one thousand diameters. eral matter, which settling to the bottom from time to time hardened into strata (layers) of rock. The skeletal portions of the animals dying also dropped to the bottom, and ofttimes left the indelible impressions of their bodies in the forming rock, or the skeletal structure was itself replaced with stone (fossilized). By contraction of the earth's crust certain portions were forced up out of the water and made ready for habitation by land animals. These coming to the water to drink or rushing into the lakes to escape from their 
enemies sometimes perished, and their skeletons were likewise entombed in the sediment-forming rock and there became fossilized. Therefore, each successive stratum or layer of rock containing the remains of the life of former ages serves as the leaf of a book giving a description of the

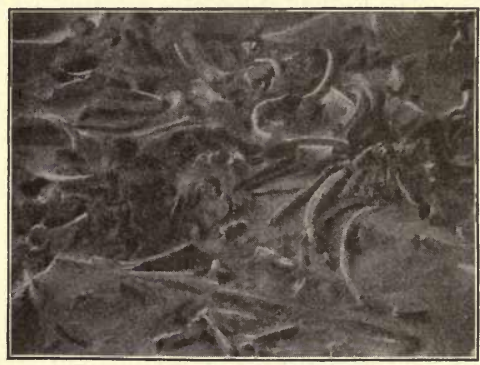

FiG. 387. - A piece of rock containing the fossil remains of several animals. Photographed in American Museum of Natural History. animate world before the era of man. By careful computation scientists have determined that life has probably existed on the earth for a period of from twenty million to one hundred million years. The fossil remains show that the invertebrates lived here more than a million years before there were any vertebrates; the fish preceded the amphibians by several million years, while as much more time elapsed before the advent of reptiles, which dwelt here at least two or three million years before the appearance of birds. There is evidence indicating that man has been on the earth from fifty thousand to a hundred thousand years, and it is possible that he has been here even a million years.

"From lower to higher,

From simple to complete,

This is the pathway of eternal feet;

From earth to lichen, 
ORIGIN OF THE DIVERSE FORMS OF ANIMAL LIFE 347

From herb to towering tree,

From cell to creeping worm,

From man to what shall be;

This is the lesson of all time,

This is the teaching of the voice sublime."

The sequence of forms in the successive rock strata makes it evident that under the stress of a rapidly changing environment certain individuals of a species changed in habit and structure so as to persist in the struggle among

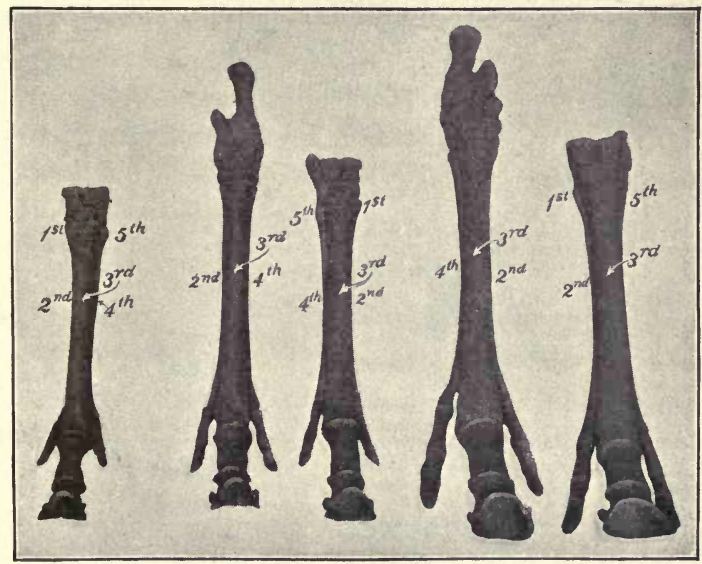

FIG. 388. - Photograph of the fossil feet of three-toed horses in the Museum of Natural History.

associates for food, and thus gave origin to a new variety or kind of animal, while those of the species which did not change to a more advantageous habit and structure became extinct. For instance, records clearly show that the 
ancestor of our horse was a three-toed iugulate scarcely larger than a sheep and with teeth adapted to feed on succulent vegetation, such as the warm, moist climate of those early days afforded. As the ground, then wet and swampy, became hard, and the juicy vegetation gave way to the dryer grasses, the lateral toes became shorter in certain

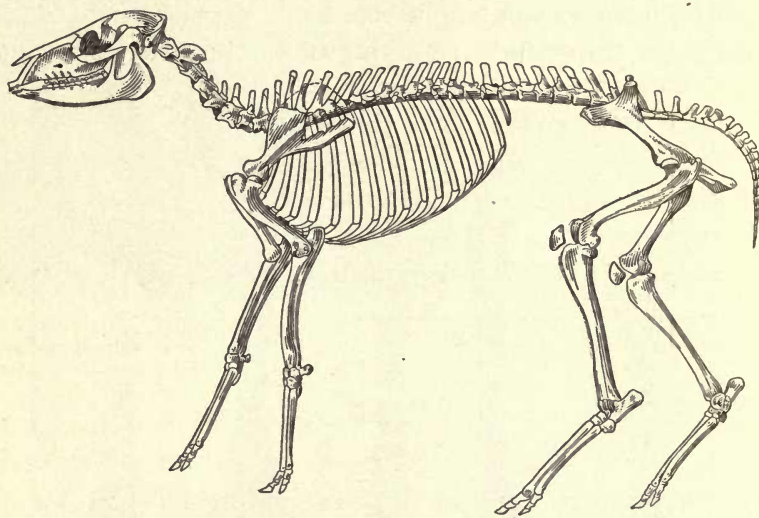

FTG. 389.- Skeleton of Mesohippus bairdi, the three-toed ancestor of our horse. This animal was about the size of a sheep. After Farr.

individuals, and the third digit grew longer and stronger, thus enabling them to escape their carnivorous pursuers, while all those individuals whose limbs and teeth did not vary so as to aid them to escape the increasing carnivorous animals and masticate the dry grasses, were exterminated. Thus age after age those horses whose lateral toes became smaller while the third one grew longer, giving them greater speed, persisted and multiplied, but those with large, lateral 
toes as an encumbrance fell prey to their pursuers. This process of developing new species is called evolution by variation and natural selection. The ancestor of the three-toed horses were four-toed animals whose remains are found in the layers of rock beneath those containing the three-toed ones. By this process of variation and natural selection the four-toed forms were derived from a five-toed mammal with such a generalized structure that other of its progeny developed into sheep, cows, and deer

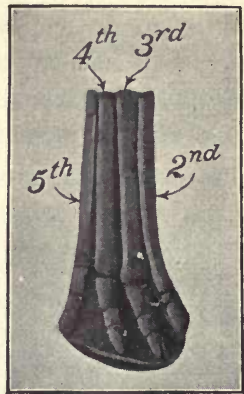

FiG. 390. - Photograph of foot of four-toed horse in American Museum of Natural History. in accordance with the various foods and changing factors

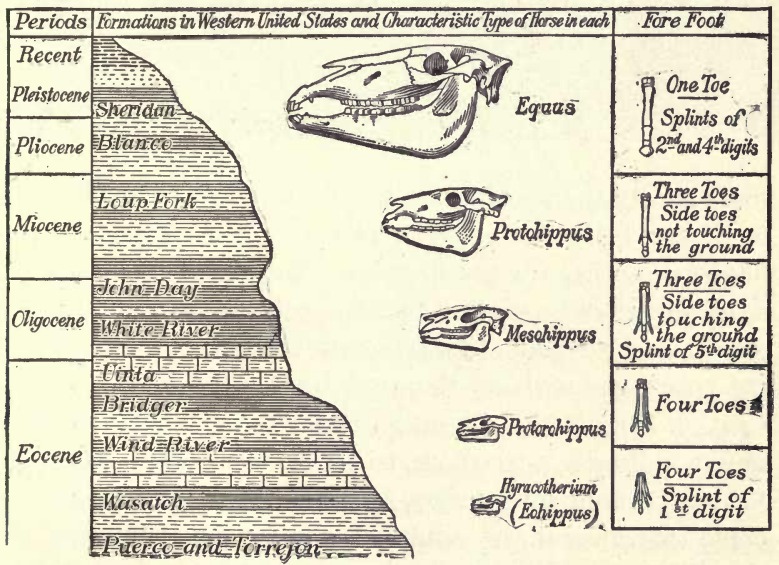

FTG.391. - After Matthews in Guide Leaflet of American Museum of Natural History. 
in nature to which they were subjected. Thus, by variation and natural selection numerous and widely different kinds of animals arose.

Variation in the individuals of certain species, and therefore evolution, is occurring at the present time, but much

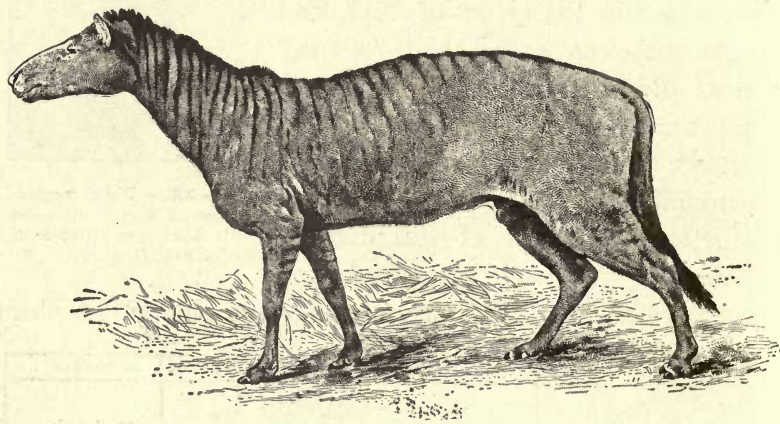

FIG. 392. - The four-toed horse restored from a study of its fossil skeleton. From Guide Leaflet of the Museum of Natural History, New York.

more slowly than during the world's infancy, when climate, food, and other factors were changing more rapidly. An observer, seeing for the first time the very dark and very light forms only of the Catalpa caterpillar, would at a glance declare them two different species, but after finding specimens with all the gradations in shade from light to dark (Fig. 394), he would be forced to consider the two unlike individuals to belong to the same species. If, in the future, the four intervening forms shown in the figure become extinct and the adults of number one and number six differ as widely as the larvæ and remain constant in 
ORIGIN OF THE DIVERSE FORMS OF ANIMAL LIFE 351

their characteristics, scientists would be warranted in recognizing the two forms as separate species.

A species of moth of the genus Saturnia, brought from Texas to Switzerland, where the young fed on the European

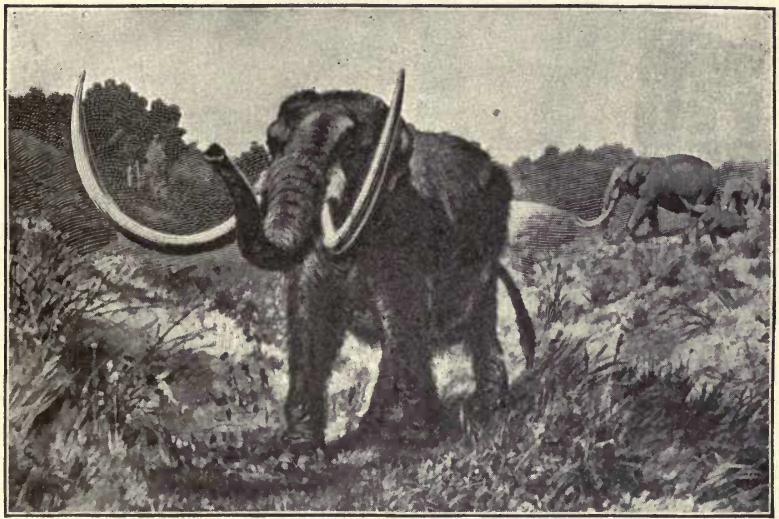

FIG. 393. - The Mastodon, an early ancestor of the elephant and long since extinct. From a painting by Knight in the American Museum of Natural History.

walnut, presented after one generation such marked differences from the same species whose young fed in Texas on the black walnut, that entomologists gave it a new name. The brine shrimp, Artemia salina, lives in slightly brackish water, while Artemia milhauseni occurs only in very salt water. If salt be gradually added to the vessel containing the former species, it will in a few generations during the months of a single summer, transform into the latter species. Likewise, Artemia milhauseni will, in a few months, change 
into Artemia salina upon the gradual addition of fresh water. The crustaceans and fish of the Mammoth Cave, though differing greatly in certain features from the forms

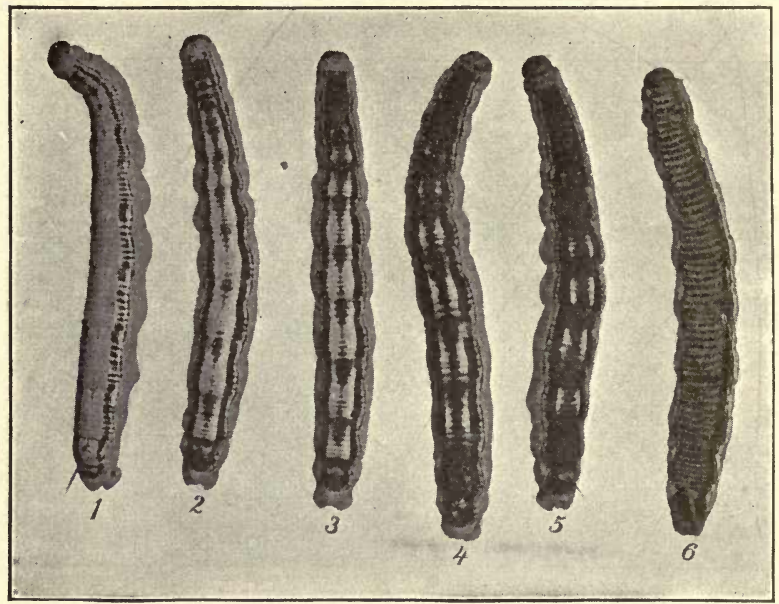

FIG. 394. - Variation in the Catalpa caterpillar. Photograph natural size.

in the waters just outside, give unmistakable evidence of being their direct descendants.

Other evidences of evolution are furnished by rudimentary structures, which are present in all of the higher vertebrates. Some of the lizards, having only one pair of legs, have rudiments of the other pair beneath the skin. The rudiments of the hind legs in the Python are apparent externally. No functional hind limbs are present in any of the whales, but several species possess small structures 
beneath the skin in the position of the hind limbs. Teeth are present in the jaws of the whalebone whales, but they never appear above the surface, and the young of the ruminants have buried in the gums minute upper incisors, though they do not develop into functional teeth in the adults. The vermiform appendix, occurring in man and the anthropoid apes, is of no use, but in their ancestors it may have played an important part in digestion, as the corresponding portion of the alimentary canal does yet in the rabbit, groundhog, and other forms. The splint bone, about ten inches long on either side of the lower part of the horses' limb, serves no useful purpose now. All of these useless structures clearly indicate that they were of larger size in the far-off ancestors in whom their presence was of great use.

Still further testimony, favoring a belief in evolution, is given by the study of Embryology which deals with the development of the young

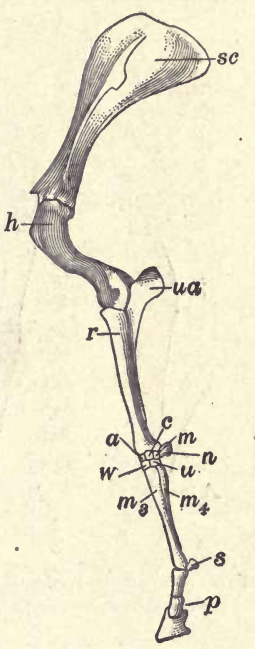

F1G. 395.-Skeleton of the fore limb of the horse. $s c$, shoulder blade; $h$, humerus ; $r$, radius; $u a$, ulna; $m_{3}$, third metacarpal; $m_{4}$, splint bone or fourth metacarpal; $p$, phalanges. From Davison's "Mammalian Anatomy." from the egg. In very young stages the higher vertebrates are seen to resemble the adult forms of some of the lower animals. The chick, when taken from an egg incubated for three days, is found to have gill slits and 
gill arches and an entire circulatory system, strikingly similar to the same structures in the fish. The brain is fishlike also. In some young birds taken from the egg,
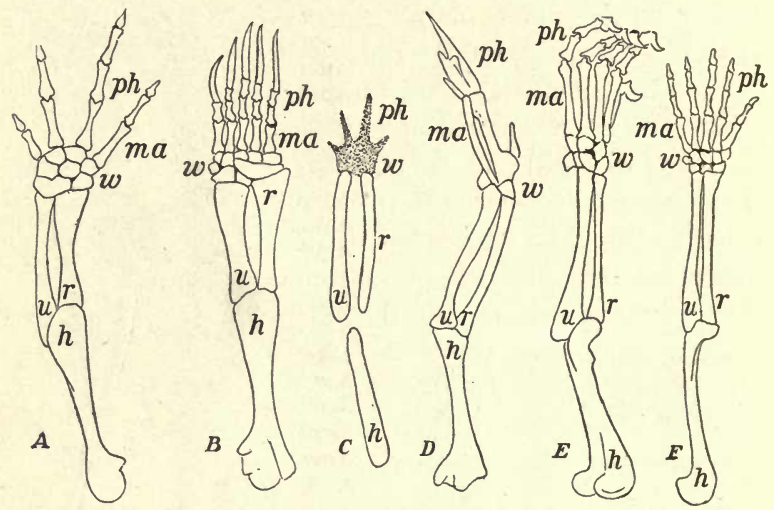

FrG. 396. - Fore limbs of vertebrates showing similarity of structure. $A$, salamander; $B$, turtle ; $C$, very young bird ; $D$, adult bird ; $E, \operatorname{dog} ; F$, man.

the wing strongly resembles in structure the limb of a lizard.

These facts, cited in the preceding paragraphs together with much other information discovered by the zoölogist and geologist, lead to the conclusion that at first there existed on earth only a few forms of simple life similar to the amœba, and from these acted on by the rapid changes of climate, soil, water, and food, have arisen all the varied forms of animal life. 


\section{INDEX AND GLOSSARY}

Adaptā'tions, 311-323.

Adder, 214, 216.

Air bladder, 196, 198.

Air sacs of birds, 227.

Alligator, 221, 339.

Alteruation of generations, 172, 173.

Ambly̌s'toma, 200, 201, 302.

Ambulā'cral, 162.

Ameiu'rus, 190.

Ammocœ'tes, 186, 300.

Amœ'ba, 179-182, 324.

Amphřb'ia (Gr. amphi, both, and bios, life), 27, 199-211. eggs of, 294-296.

Anaconda, 220.

Anăt'omy, 11.

Anem'onē, 174.

Angle worms, 152-154.

Anguillū'la, 155.

Animăl'cule, a minute animal, $178,180$.

Annulat'a (L. annulus, ring), 25,

150-154.

Anodont'a, 143.

Ano'lis, 212.

Anŏph'elēs, 41, 42, 182.

Ant-eater, 263, 264.

Antelope, 336.

Anten'næ, 32, 68, 120, 307.

Anthŏn'omus, 108, 109.

Anthrenus, 113, 114.

Anthropoid apes, 281.

Ant-lion, 117.

Ants, 24, 56-57.

cows of, 98 .

Anu'ra, 204.
Apes, 281.

Aph'idæ, 95.

Aphis, 97.

Apple tree borer, 24, 111.

worm, 87.

Aquăt'ic, dwelling in the water.

Aquaria, 19.

Arăch'nida (Gr. arachne, spider), $26,125-132$.

Arbac'ia, 164.

Archæŏp'teryx, 227.

Argi'ope, 130.

Armadillo, 264.

Armored scales, 103.

Army worm, 24, 48, 85.

Arte'mia, 351.

Ar thrŏp' o da (Gr. arthron, joint and poda feet), 26, 30-40. parasitic, 327-333.

Ascaris, 325.

Asparagus beetles, 24 .

Aspidiotus, 98-102.

Assassin bugs, 105.

Aste'rias, 161-165.

Audubon society, 24.

Auricle, the cavity of the heart which receives the blood, 289.

Aves, 27, 226-261.

Ax'olotl, larva of the Amblystoma mexicanum, 209, 302.

Baboons, 281.

Bacteria, 344, 345.

Baltimore oriole, 24, 235.

Bark beetle, 24, 109.

Bark lice, 98-104. 
Barnacles, 139, 140, 299.

Bats, 273, 274.

Bead snake, 216.

Beans, insects affectıng, 278, 279.

Bear, 278, 279.

Beaver, 337.

Bee, eye of, 310.

Bee keeping, 23.

Bee martin, 232.

Bees, 52-55.

Beetles, 107-115.

Bedbug, 24, 104.

Bell animalcule, 180.

Beneficial insects, 47, 48, 51-56. Bi'nary fission, a method of reproduction in which the organism divides into two equal parts, 179, 182.

Biǒl'ogy, the study of plant and animal life, 11.

Bird day, 24.

Bird, external features, 229.

Birds, 226-261.

decrease in, 227.

destruction of, 255-257, 339 .

eggs of, 234.

food of, 24.

in relation to insects, 258 .

migration of, 24, 260 .

Bison, 266.

Blackbirds, 236.

Black crab, 116.

Black snake, 214, 216. eggs of, 293.

Black swallowtail, 72 .

Bladder worm, 159.

Blind eray fish, 141.

Blissus leucop'terus, 105.

Blowfly, 46.

Bluebird, 243, 248, 259.

Blue crab, 138.

Blue sharks, 188.

Boa constrictor, 220, 221.

Bobolink, 235.
Bobwhite, 318.

Boll worm, 23.

Bomby̆c'idæ, 74.

Bones of bird, 354 .

of cat, $290,291$.

of $\mathrm{dog}, 354$.

of horse, 266, 353.

of man, 354 .

of salamander, 354 .

of turtle, 354 .

Bony fish, 189.

Borer, apple tree, 111.

locust, 111.

maple, 112.

peach tree, $89,90$.

pine tree, 112.

Borers, certain insect larvæ, mostly of beetles and moths, dwelling in trees, 89 .

Botflies, 48-50, 330.

Box tortoise, 222.

Brain of cat, 287, 288.

mammals, 290.

Breeding of amphibians, 207.

Brine shrimp, 351.

Brittle star, 166.

Brontosau'rus, 226.

Brush-footed butterflies, those with imperfect and hairy forelegs, 69 .

Bŭc'cal, 179.

Buffalo, 266, 335, 336, 337.

moth, 24, 113.

Bufo, 207.

Bugs, 91.

Bulletins and circulars of Agricultural Department of U.S., $23,24$.

Bull frog, 205.

Bull head, 189.

Bumble bee, 54, 306.

Butterflies, 68-73.

Butterfly, protective resemblance, 313. 
Cabbage butterfly, 71 .

fly, 47. worms, 67, 72, 73.

Cabinets for insects, 17.

Caddis fly, 311.

Cæca (sē ka) (L. caecus, blind), 163.

Camel, 268, 271.

Canidæ, 277.

Canker worms, two species of moth larvæ which destroy the foliage of fruit trees, 24 , $85,86,258$.

Car'apace, the dorsal part of the hard shell of crustaceans and turtles, 133, 222.

Caribou, 267.

Carnǐv'ora (L. caro, flesh, and voro, devour), 28, 275-280.

Carpet beetle, 24, 113.

Cartilaginous fish, 187-189.

Catal'pa caterpillar, $350,352$.

Catalpa moth, 47, 64, 65.

Catamount, 276.

Catbird, 240, 244, 258.

Caterpillar, the larva of a moth or butterfly, 74 .

Catfish, 189, 190.

Cats, 276.

Cattle, 266.

Cattle tick, 328.

Cave animals, 308.

Cave fishes, 192.

Cedar bird, 240, 242, 258.

Cell, a microscopic portion of semifluid life-substance called protoplas m, usually surrounded by a thin membrane and containing a nucleus, $178,289,293,294$.

Centiped, 18, 24, 132.

Ceramby̌c'idæ, 111.

Cetä'cea (L. cetus, whale), 28, 264.
Chalcis flies, 67, 68, 331 .

Chalk formers, 183.

Chameleon, 212.

Chatterers, 240.

Chelo'nia, 222-225.

Chickadee, 242, 258, 259.

Chimney swift, 244, 249, 250.

Chimpanzee, 282.

Chinch bug, 12, 105.

Chipmunks, 270.

Chipping sparrows, 238, 239.

Chippy, 238.

Chirŏp' ter a (Gr. cheir, hand, and pteron wing), 28, 273, 274.

Chlor'etone, a one per cent solution added to from five to ten times as much water renders aquatic animals unconscious, 21, 210.

Chloroform, 19.

Chry̆s'alid, the pupal stage of a butterfly, 71.

Cica'da, 92-95, 298.

Clams, 142, 143.

Class, 26.

Classification of animals, 25-29.

Clavicorn beetles, 113.

Clear-winged moths, 89, 90.

Click beetles, 113 .

Clothes moth, 24, 88, 89.

Clover seed midge, 51 .

Clupea, 190, 191.

Cobra, 220.

Coc'cidæ, 98.

Coccinel'lidæ, 114.

Cochineal insect, 103.

Cockroaches, 24, 38.

Co coon', the case formed of soil, hair, silk, or other material, in which many insects pass the pupal stage, $77,88,90$, 331.

Coddling moth, 23, 87, 88, 125

Codfishes, 193. 
Cœlenterata (se len' ter $a^{\prime}$ ta) (Gr. koilos, hollow, and enteron, intestine), 25, 167, 175.

Cœlome (sēlome), body cavity, $157,168$.

Cold-blooded animals, 196.

Cōl e óp' te ra (Gr. koleos, sheath, and pteron, wing), 27, 107, 115.

Commen'salism, 177.

Condor, 249.

Congo snake, 203.

Conjuga $\bar{a}^{\prime}$ tion, a process of union whereby protoplasm is transferred from one organism to another, 180.

Cooper's hawk, 251, 253.

Copperhead, 218, 219.

Coral, 175.

Corn worm, 84.

Cotton boll weevil, 12, 23, 108.

worm, 84 .

caterpillar, 68.

insects affecting, 23.

Cow bird, 236.

Coyotes, 277.

Crabs, 136-138.

Cranberries, insects affecting, 23.

Crane, 254.

Crane flies, 44.

Crawfish, 135, 136.

Cray fish, 135, 136.

Creation of animals, 342-354.

Cricket, 36, 37.

Crinoids, 166.

Crocodilia, 221, 222.

Crotalidæ, 216.

Croton bug, 38.

Crows, 233, 235.

Crustā'cea (L. crusta, crust), 26, 133-141.

Crustaceans, netamorphosis of, $299,300$.

Cry̆ptobran'chus, 203.
Cuckoos, 247, 251, 258.

Cucumber beetles, 24 .

Cūlex, 39, 41, 42, 44.

Curcū'lio, 107.

Currant saw fly, 58.

Cuttlefish, 149.

Cutworms, 82-84.

Cy'anide jar, 19.

Cyclostom'ata, 185-187.

Cypris, 139.

Cysticercus (šs ti sŭr' kus) (Gr. kystis, bladder, and kerkos, tail), the larval stage of a tape worm, 159, 296, 327 .

Damsel flies, 119, 120.

Daphnia, 139.

Deer, 267, 268.

Desmognathus, 201, 203.

Diapherom'era, 314.

Diaphragm, 285.

Digitigrade, 266.

Digits, 265, 292.

Diaspis, rosæ, 103.

Digestive system.

Cat, 285.

Cray fish, 134.

Fish, 197, 198.

Frog, 209.

Honey bee, 53.

Locust, 123.

Dipnoi, 185, 195.

Diplodocus, 226.

Dǐp'tera (Gr. di, two, and ptera, wings), 27, 39-51.

Disease, insect carriers of, 24.

Dobson, 116.

Dog-day fly, 94 .

Dogfish, 188.

Dogs, 277.

1)olpu ins, 264.

Dinosau'ria, 225.

Downy woodpeckers, 247.

Dragon flies, 118. 
Drone fly, 48.

Drones, 52, 55.

Duck bill, 261.

Duck mole, 261, 262.

Eagles, 248, 249, 252, 257.

Ear, 199, 307, 308.

Earthworms, 152-154.

Echĭd'na, 262, 263.

Echinoidæ, 165.

Echinoder'mata ( Gr. echinos, hedgehog, and derma, skin), 25, 161-167.

Econom'ic zoölogy, 12.

Ec'toderm (Gr. ectos, outside, and derma, skin), 168.

Ectopisteus migratorius, 338.

Edenta'ta, 27.

Eel, electric, 312.

lamprey, 185.

mud, 204.

Eggs, 293-296.

of amblystoma, 203.

of birds, 234 .

of Lepidoptera, 90.

of moth, 297.

Egret, 255.

Elăs'mobran'chii, 185, 187-189.

Elater'idæ, 113.

Electric eel, 312.

Electric fish, 189.

Elephant, 268, 269, 272.

Elk, 267, 269.

El'ytra, pleural of el'ytron.

El'ytron (Gr. elytron, case), the thickened anterior wings of beetles and some other insects.

Em'bryo, 294, 303.

Encysted, 182.

Ephemer'ida (Gr. ephemeros, lasting a day), 26, 117.

En'doderm, 168.

English sparrow, 237, 294.

Entomðs'traca, 299.
Equipment, 14.

Evolution of animals,342-354.

Eye of cat, 288.

fish, 198.

insects, 120 .

locust, 34 .

Eyes, 308, 310.

Fall webworm, 64.

Families, 28.

Feeling in animals, 303-305.

Fel'idæ, 276.

Fertilization, 172.

Fiddler crabs, 137.

Fig culture, 24.

insect, 61.

Filaria, 325.

Finches, 236.

Firefly, 112.

Fish, 185-199.

Fish, characteristics of, 196.

hearing in, 307.

lice, 333 .

products, value of, $\mathbf{3 4 1}$.

Fission, 179.

Flatfish, 194.

Flatworms, 157-161, 326, 327.

Fleas, 51, 329.

Flicker, 246, 250.

Flies, 24, 39-51.

Flounders, 194, 195.

Fly catchers, 230-232.

Flying fish, 192.

Flying foxes, 273.

Food of nestling birds, 24.

Forest tent caterpillar, 78,81 .

Forest snail, 148

Forests, insects affecting, 24.

For inăl'de hyde, 18.

Formaline, 18.

Forelimbs of vertebrates, 354 .

Fossil animals, 225, 345-350.

birds, 227.

mammals, 265. 
Foxes, 276, 277.

Fresh water clams, 143.

Frog, development of, 301.

structure of, 209-211.

Frogs, 204-206.

Frogs' eggs, 294-296.

Galley worm, 133.

Gall flies, 59-63.

Gallinæ, 253.

Gang'lion, a group of nerve cells, 123.

Garden spider, 129.

Garter snakes, 214, 293.

Gem'mules (L. gemma, bud), 176.

Gern'era, plural of genus.

Genus, 28.

Ge o met' ri dæ (Gr. ge, earth, and metron, measure), 85 .

Gibbons, 281.

Gila monster, 213.

Gill arches, the three or four bony arches on either side of the pharyn $x$ of fishes bearing the gill tufts, 198.

Gills, organs of respiration used by most aquatic animals, 162 , 189, 204, 302.

Gland, a structure for secreting a useful substance, 78 .

Glass snake, 212.

Globigerina, 183.

Glow worm, 113.

Golden robin, 235.

Goose barnacles, 140.

Gordius, 156.

Gorilla, 281.

Grackles, 236.

Grain, insects injurious to, 23.

Grain weevil, 108.

Grape-vine louse, 97.

Grandady-long-legs, 130.

Grantia, 175.

Grasshopper, anatomy of, 123.
Grasshoppers, 30, 31.

sounds of, 37 .

Grass spider, 126.

Great horned owl, 252.

auk, 335.

Green frog, 205.

Green turtle, 224.

Ground hog, 270. 273.

Gynnophiona, 207.

Gypsy moth, 80, 125.

Hairy woodpecker, 247.

Halibut, 194.

Hares, 271.

Harlequin bug, 105.

Harvest flies, 93.

Harvestmen, 130.

Hawk moths, 73, 74.

Hawkbill turtle, 224.

Hawks, 12, 248, 249, 253, 254, $255,256$.

Hearing, 307.

Heart of Amphibian, 210. of crayfish, 136.

of mammal, 287.

of reptile, 226 .

Hedgehogs, 275.

Heel fly, 49.

Helix, 149.

Hellbender, 203.

Hellgramite, 116.

Heloderma, 213.

He mip' te ra (Gr. hemi, half, and pteron, wing), 26, 91-107.

Hen hawk, 251.

Hermit crab, 173, 138.

Herons, 254, 255.

Herrings, 190.

Hessian fly, 50, 125.

Hěterop'tera, 104.

Hibernation, passing the winter in a dormant condition, 31 .

High-holer, 246, 250.

Hippocampus, 193. 
Hirudo, 151.

Holothuroi'dea, 166.

Honey bee, 52-54, 121, 298.

Honey dew, 57.

Hop louse, 24, 97 .

Hornet, 55.

Horn tail, 331.

Horse hair worms, 156, 157.

Horse bot, 330 .

Horse, limb of, 353.

skeleton of, 266.

Horses, 265, 266, 347-350.

Host, 323.

House flies, 24, 45.

Humming birds, 244, 249.

Hȳdra, 168-170, 344.

Hydroids, 170, 171, 172.

Hyla, 205, 206.

Hȳmenop'tera (Gr. hymen, membrane, and pteron, wing), 27, $52-68$.

Ichneumon flies, 63-67, 331.

Ima's'go, the adult form of an insect, $73,91$.

Infusoria, 178-180.

Injurious insects, 12, 23-24, 34, 48-50, 124, 125.

Instinct in animals, 55 .

Insec'ta (L. in, in, and seco, cut), $26,30-125$.

Insecticide, a substance used in killing insects, 23, 114.

Insectiv'ora, $27,274,275$.

Insects, 30-125.

feeling in, 303.

hearing in, 308 .

injurious, 12, 23, 24, 34, 48$50,124,125$.

parasitic, 329-333.

preservation of, 15 .

smell in, 307.

structure of, 121, 123.

taste in, 306.
Io, 311.

Itch mite, 131, 328.

Jaguar, 276.

Jar fly, 94.

Jays, 235.

Javelin bat, 274.

Jellyfish, 173, 174, 296.

Jigger, 131.

June beetle, 110.

Kallima butterfly, 313, 314.

Katydid, 31, 315.

Kangaroos, 262, 263.

Killing of animals, 18, 114.

Kingbird, 230, 232.

Kissing bug, 105.

Labium, lower lip, 32, 42.

Labrum, upper lip, 32, 42.

Ladybird beetles, 101, 102, 114.

Lamellicorn beetles, 110 .

Lamprey eel, 187-188.

Larva, the first active young stage of many animals, $39,90,207$, 208, 298, 301, 302.

Leaf rollers, 86.

Leaf butterfly, 313,314 .

Leaf-eating beetles, 115 .

Leeches, 150-152.

Lemurs, 280.

Leopard frog, 206.

Lepidop'tera (Gr. lepis, scale, and pteron, wing), 26, 68-91.

Lepidosiren, 195.

Lepomis, 193.

Leporidæ, 271.

Lernea, 333.

Leucoselenia, 175.

Lice, 24, 57, 95-98, 328, 329.

Lightning bug, 112.

Limax, 149.

Liver fluke, 326.

Linnæus, 28.

Lion, 276. 
Lion, mountain, 276.

Lizards, 211-213. egg of, 293.

Lobster, 136, 341.

Locust, anatomy of, 32-34, 123. borer, 111.

Carolina, 36.

red-legged, 35.

Rocky Mountain, 12, 35.

Loggerhead turtle, 224.

Long-eared owl, 253, 258.

Longicorn beetles, 111.

Lucanus, 111.

Lumbricus, 152.

Lung fishes, 194.

Lungs of salamanders, 201.

Lynx, 275, 276.

Mackerel, 192, 193.

Madrepor'ic, 162.

Maggot, 47, 122.

Magpie, 235.

Malacostraca, 299.

Malarial parasite, 183.

Malaria mosquito, 41, 42.

Mammā'lia (L. mamma, breast), 27, 261-292.

Mammal, structure of, 28:3-292.

Mammoth, 335, 336.

Man, age of, 335.

Manatee, 264.

Mandibles, 32.

Man-eater, 188, 277.

Mantle, 145.

Maple borer, 89.

gall, 61 .

louse, 97. scale, 103.

Marmoset, 280.

Marmots, 270, 273.

Marsū'piā'lia (L. marsupium, a pouch), 27, 263, 264.

Marten, 278.

Mastodon, 351.
Maxillæ, 32.

May flies, 117.

Meadow lark, 24, 236.

Mealy bug, 103.

Measuring worms, 85, 315.

Medicinal leech, 151.

Medū'sæ, 172.

Měso hřp'pus, 348.

Metamor'phosis (Gr. meta, over, and morphe, form) the change from one stage to another in the development of the young, 51, 90, 91, 93, 121, 295-302.

Mice, 270, 271.

Microscope, a convex lens or a combination of several such lenses for magnify ing objects, 21.

Migration of birds, 24, 260 .

Milk snake, 214, 216.

Milkweed butterfly, 69 .

Millipeds, 132.

Mǐm'icry, 214, 321.

Mink, 278.

Mite, 131, 327.

Moa, 335 .

Mŏc'casin, 214, 219.

Mole, 275.

Molting, shedding the outer skin or feathers, 215, 221.

Molting of crustaceans, 137. of insects, 31 .

Mollŭs'ca, 26, 142-150.

Molluscoi'da, aquatic worms which, to the casual observer, appear like plants, 25.

Monarch butterfly, 69 .

Monkeys, $280 \cdot 283$.

Monotremata, 27, 261-263.

Moose, 267, 269, 336.

Mosquitoes, 24, 39-45.

Moth, eggs of, 297.

Moths, 68, 73-91.

Mounting of animals, 18. 
Mourning cloak, 70.

Mouth parts of insect, 32. of mosquito, 46.

Mud eel, 204.

Mud fish, 196.

Mud puppy, 203.

Mud wasps, 55.

Mur'idæ, 270.

Mus, 271.

Museum pest, 114.

Muscles, 283-285.

Mussel, 143, 144.

Muskrat, 270.

Mya, 142.

M ÿriăp'oda (Gr. myroi, ten thousand, and poda, feet), 26, 132.

Mysis, 299.

Mytilaspis, 102.

Nares, 210.

Natural History, 11. selection, 322, 347-350.

Nau'plius, one of the larval forms of crustaceans, $299,300,333$.

Nautilus, 150.

Necturus, 203.

Nem' a thel min' thes (Gr. nema, thread, and helminth, worm), $25,155-157$.

Nem'atocyst, 168.

Nemertini, 161.

Nephrĩd'ia, organs of excretion in the lower animals, 154 .

Nerves, termination of, $305,308$.

Nervous system of bee, 121.

of cat, 289.

of cray fish, 134 .

of fish, 197, 198.

of frog, 209, 211.

Neurŏp'tera, 26, 116.

Newt, 199, 200

Night walker, 152.

Noctuidæ, 82.
Nomen'clature, 28.

Notochord, 186, 187.

Nuthatches, 241, 245.

Nut weevil, 107.

$\mathrm{Nymph}$, the young form of insects which do not have a complete metamorphosis, 31, 36, 298.

Oak galls, 60, 67 .

Oak-leaf rollers, 87.

Ocelli, simple eyes of insects, 34.

Odonata, 26, 118.

Opalina, 327.

Operculum, 189.

Ophidia, 213, 221.

Ophion, 66.

Ophisau'rus, 212.

Ophiuroi'dea, 166.

Opossum, 263, 264.

Orang-outang, 282.

Orchard, birds affecting, 24.

Order, the several groups of an. imals composing a class or subclass, 26.

Organism, an individual plant or animal, 11.

Origin of species, $342-354$.

Orioles, 235.

Or'nithorhy̆n'chus, the duck mole, 262.

Orthop'tera (Gr. orthos, straight, and pteron, wing), 26, 30-38.

Ovǐp'arous, producing eggs, 213

Ovipositor (L. ovum, egg, and positum, placed), a projection from the end of the abdomen of insects used in egg-laying, $33,57,94$.

Owls, 12, 32, 248, 252, 253, 258.

Owlet moths, 82.84 .

Ox bot, 24, 49, 330 .

Oyster, 143.

crab, 139.

Oyster-shell scale, 102. 
Painted terrapin, 223.

Partridge, 254.

Păr a mœ' cium, 178.

Parasites, organisms feeding on

living tissues, whether plant or animal, of fish, $332,333$.

of honey bee, 51 .

of insects, 330-332.

of man, 131, 155, 158-160.

Parasitism, 323-334.

Par'thenogen'esis, the production of young from eggs not fertilized, as in some cases among plant lice, ants, bees, and wasps, 54, 95, 96, 161.

Passeres, 231.

Peach tree borer, 24, 89, 80.

Pea louse, 97.

Pearl oysters, 144.

Pearly nautilus, 150.

Pear slug, 24.

Peas, insects affecting, 24.

Pea weevil, 108.

Perching birds, 231.

Peritoneum, 198, 210, 286.

Pernicious scale, 98.

Petrel, fulmar, 334.

Petromyzon, 188.

Pewee, 232.

Phœbe, 232.

Phorodon, 97.

Photinus, 112.

Phyla, same as subkingiom, 28.

Phylloxera, 97.

Physiology, 11.

Pieris, 71.

Pigeon hawk, 254.

Pigeon, wild, 338.

Pill bugs, 140.

Pilot, 218, 219.

Pimpla inquisitor, 64.

Pine-bark beetle, 110.

Pine tree borer, 112.
Pinnipédia, 279.

Pisces, 27.

Puma, 276.

Planaria, 160.

Plantigrade, 266.

Plant lice, 95-98.

Plastron, 223.

Plat' yhelmin' thes (Gr. platys, flat, and helmins, worm), 25, 157-161.

Plethodon, 201.

Pleura, 286.

Pleuronec'tes, 194.

Plum curcū'lio, 107.

Poisonous lizard, 213.

snakes, 313.

Polar bear, 278.

Pollinä'tion by insects, 54, 62.

Pol'yp, a fixed individual animal of the Colenterata, 170.

Polyphemus, 75.

Pond snail, 147, 148.

Porif'era, 25, 167, 175-177.

Porpoises, 264.

Potassium cyanide, 19.

Potato beetle, 115.

Prairie dog, 270.

Preservation of material, 15.

Pri'mates (L. primum, first), 28, 280-283.

Proglŏt'tides, 159.

Promethea, 76, 297.

Protective coloration, 313-323.

Proteus, 203.

Pro'tochorda'ta, 27.

Prô'toplasm, the semi-liquid material forming the greater part of the cells, 179, 180 .

Prôtozō'a (Gr. protos, first, and zoön, animal), 25, 178-184.

Pseū'dopods (Gr. pseudeo, false, and poda, feet), 182.

Ptarmigan, 319, 320.

Pulex, 329. 
Puppa, the last stage in the development of an insect before assuming the adult form, 40,91 , 298.

Pupate, to transform into the state of a pupa, 74 .

Python, 219, 220, 352.

Quahog, 142.

Quail, incorrect name for bobwhite, 318.

Queen, 52, 55, 56.

Rabbits, 214, 216, 334, 835.

Racer, 214, 216.

Rain worms, $\$ 52$.

Raja, 189.

Rana, 205.

Raptores, 248.

Rats, 270, 271.

Rattlesnake, 217, 818.

Rays, 187, 189.

Red-backed salamander, 201.

Red bat, 278.

Red-tailed hawk, 251, 256.

Reed bird, 235.

Regeneration, the renewal of a lost part, 154.

Reindeer, 23, 267.

Reproduction in animals, 344.

Reptilia, 27, 211-226.

Rhizŏp'oda (Gr. rhiz, root, and poda, feet), 180.

Rice bird, 235.

Roaches, 38.

Robin, 242, 246, 247, 258, 259.

Rocky mountain goat, 266, 267.

locust, 12, 35, 259.

Rodentia(L. rodens, gnawing), 28, 269.

Rose aphids, 96.

Rose-breasted grosbeak, 236, 237.

Rose, insects affecting, 59 .

Rose scale, 103.
Rótifers, microscopic worms often present in stagnant water, 161. Round worms, 155, 157, 325.

Rudimentary structures, those which by evolution have become too small to be of use as the tot on either side of the foot of a cow or pig, 352.

Rü'minants, hoofed animals which chew the cud, 268,353 .

Sacculi'na, 332.

Salamanders, 200-204.

Salmon, 191, 340.

Salvelinus, 192.

Sand dollars, 166.

Sand wasps, 55 .

Sanina, 89.

San Jose scale, 24, 98-102.

Saw fishes, 189.

Sawflies, 57-59.

Scale insects, sucking insects which excrete material forming a covering for the body, 23, 24, 98-104.

Sceleporus, 212.

Scolopendra, 133.

Scomber, 192, 193.

Scorpion, 132.

Screech owl, 253, 258.

Scurfy scale, 103.

Sea anem'one, 174, 805 .

cow, 264, 335.

cucumber, 166.

horse, 193.

lily, 167.

lion, $279,280,337$.

Seal, $280,337$.

Sea urchin, 164-166.

Senses of animal, 303-310.

Serous membranes, 286.

Sertularia, 172.

Sesia acerni, 88.

Sesiidæ, 89. 
Seventeen-year cicada, 92, 298. locust, 92, 298.

Shad, 191, 334.

Shade trees, insects enemies of, $23,79,83$.

Sharks, 187-189.

Sharp-shinned hawk, 251, 254.

Sheep tick, 51.

Shellfish, 142-147.

Shipworm, 144.

Shrew, 274, 275.

Shrimp, 141, 300 .

Silk worm culture, 23.

Silk worms, 75-78.

Silver-fish, 24.

Silver-spotted fritillary, 70.

Siren, 204.

Siren'ia, 28, 264.

Skate, 189.

Skeleton of cat, 290. horse, 266.

Skinks, 212.

Slipper animalcules, 178.

Sloths, 264.

Slug, 148.

rose, 59.

pear, 59.

Smell, 306, 307.

Snail, 147, 148.

Snake embryo, 303.

Snakes, 213-221.

Snapping turtle, 223.

Snout beetles, 107.

Snowy owl, 321.

Sō'mites (Gr. soma, body), 33.

Song sparrow, 239, 240.

Sow bug, 140.

Sparrow hawk, 251, 255.

Sparrows, 236-240.

Species, 28.

Sperm, the male cell which, uniting with the egg, fertilizes it, thus rendering it capable of developing into a new animal, 170, 172.
Spermatozo'a, plural of spermatozoön.

Spermatozoön, same as sperm.

Sphinx moths, 73.

Spider crab, 316.

Spiders, 125-130.

Spinnerets of spiders, 129.

Spinning moths, 74.

Spiny ant eater, 263.

Splint bone, 266, 353 .

Sponges, 175-177.

Spontā'neous generation, the development of a living body from dead material, $342-344$.

Spores, 182, 343.

Sporozō'a, 182.

Spring peeper, 206.

Spruce beetles, 109.

Squalis, 187.

Squamata, 211.

Squash bug, 24, 105.

Squid, 149.

Squirrels, 270.

Stable fly, 46.

Stag beetle, 111.

Starfish, 161, 165.

Stegomy'ia, 41.

Sternum, 33.

Stinging insects, 51-56.

Strawberry weevil, 24, 109.

Strongylus, 325.

Struggle for existence, 334 .

Subkingdoms, 25-28.

Suckers, 190.

Sunfishes, 193.

Survival of the fittest, 334 .

Swallows, 240.

Swallowtails, 71.

Swifts, 244, 249, 250.

Symbiō'sis, 323.

Syrphus flies, 48.

Tach'ina flies, 47, 332.

Tadpole, 207, 208, 301, 302.

Tænia, 158, 327. 
Talons, 249.

'Tape worms, 158, 326, 327.

Tarantulas, 126.

Taste, 305.

'Teleǒs'tomi, 185, 189-199.

'Tendon, 284.

Tent caterpillar, 78-82.

Tergum, 33.

Terrapin, 223.

Terrestrial, living on land.

Thales'sa, 66, 331.

Thamnō'phis, 214.

Thorax, 32.

Threadworms, 155-157.

Thrushes, 242, 243, 247.

Tick, 51, 327, 328.

Tiger, 276.

Tin'ea, 88, 89.

'Tinē'idæ, 88.

Tine'ola, 88.

Titmouse, 242.

Toad, 23, 206, 267.

eggs, 294, 295.

Tobacco, insects affecting, 23.

Tomato-worm moth, 74.

Torpedo, 189.

Tortoises, 222, 223.

Tortricidæ, 86.

Trā'chea, 34 .

Trapdoor spider, 128.

Tree frog, 205, 206, 316.

Trichina, 155, 156, 325.

Troch el min' thes (Gr. trochos, wheel, and helmins, worm), aquatic worms, 25.

'Trout, 192.

Tulip tree scale, 103.

'Turtle, egg of, 293.

Turtles, 222, 224.

Tussock moths, 79, 83.

Tympanic membrane, 397, 308.

Umbo, 145.

Ungula'ta (L. unguis, nail), mammals bearing hoofs, 28,265 .
Unio, 143.

Urchins, 165.

Urodela, 200-204.

Ur'sidæ, 279.

Vampire bats, 274.

Vanessa, 71.

Variation, 347-352.

in color, 278, 279, 320-323.

Veliger, 299.

Venomous, poisonous, 216, 218.

Ventricle, the cavity of the heart sending forth blood, 289.

Venus, 142.

Vermes, worms, 150, 161.

Vermiform appendix, 353.

Vertebrata, 27, 185-292.

Vesper spariow, 239.

Vinegar eel, 155.

Vireo, 242, 243, 258.

Vivip'arous, giving birth to young instead of laying eggs.

Vocal cords, 287.

Vorticel'1a, 180.

Vulpes, 277.

Vulture, 249.

Walking stick, 37, 314.

Walruses, 279.

Warble-fly, 330.

Warblers, 258.

Wasps, 55, 59.

Water boatman, 106.

Water fleas, 138, 139.

Water moccasin, 214.

Water snake, 215.

Weasel, 277, 278, 322.

Weevils, 23, 24, 107.

Whales, 264, 352.

Wheat, insects affecting, 23, 50, 57.

midge, 51.

Whip-poor-will, 245, 318.

Wildcat, 275, 276. 
Wild pigeon, 338.

Wire worms, 113.

Witch-hazel galls, 61 .

Wolves, 277.

Woodchuck, 270, 273, 337.

Woodeock, 317.

Wood lice, 141.

Woodpecker, 245, 259, 293.

Wood thrush, 243, 247.

Wood tortoise, 222.

Workers, 52, 55 .

Worms, 25, 26, 150-161. parasitic, 324 .

Wrens, 240, 241, 245.
Yearbooks of Department of Agriculture, 23.

Yellow fever mosquito, 41.

Yellowjacket, 55.

Young, development of, 294-303.

Zоæa, 299.

Zoölogy, 11.

economic, 12.

Zōoöphytes (Gr. zoön, animal, and phyton, plant), plantlike animals, such as hydroids, 172. 



THIS BOOK IS DUE ON THE IAST DATE STAMPED BELOW

AN INITIAL FINE OF 25 CENTS WILL BE ASSESSED FOR FAILURE TO RETURN THIS BOOK ON THE DATE DUE. THE PENALTY WILL INCREASE TO 50 CENTS ON THE FOURTH DAY AND TO \$1.00 ON THE SEVENTH DAY OVERDUE.

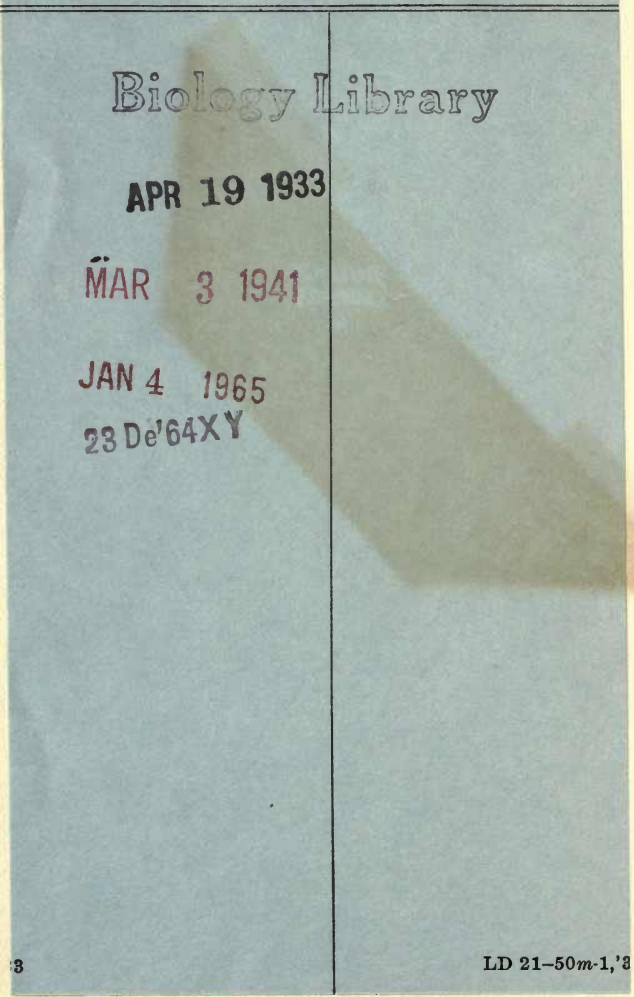


$-1=0$ of

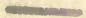

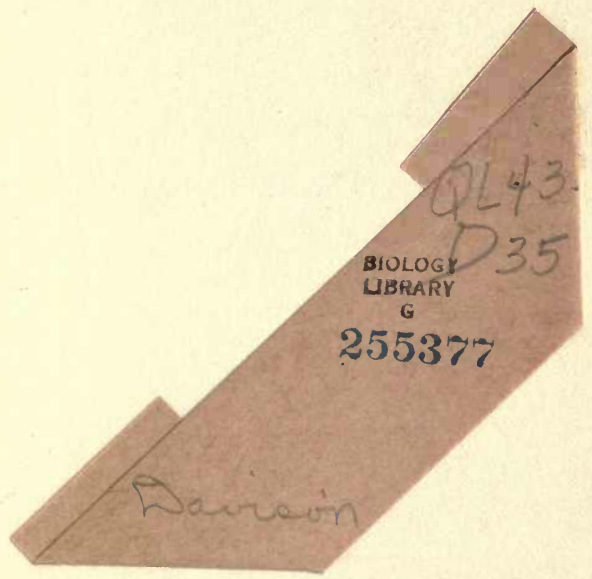




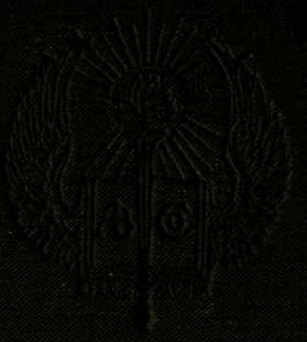

